


\title{
Monitoring von Membranen und membrangebundenen Dehydrogenasen in Essigsäurebakterien
}

\author{
Dissertation zur Erlangung des Doktorgrades \\ der Mathematisch-Naturwissenschaftlichen Fakultäten \\ "Doctor rerum naturalium" \\ der Georg-August-Universität zu Göttingen
}

im Promotionsprogramm Biologie der Georg-August University School of Science (GAUSS)

vorgelegt von

Sebastian Kokoschka

aus

Göttingen, 2013 
Betreuungsausschuss

PD Dr. Michael Hoppert, Abteilung Allgemeine Mikrobiologie, Institut für Mikrobiologie und Genetik

Prof. Dr. Jörg Stülke, Abteilung Allgemeine Mikrobiologie, Institut für Mikrobiologie und Genetik

Mitglieder der Prüfungskommission

Referent: PD Dr. Michael Hoppert, Abteilung Allgemeine Mikrobiologie, Institut für Mikrobiologie und Genetik

Korreferent: Prof. Dr. Jörg Stülke, Abteilung Allgemeine Mikrobiologie, Institut für Mikrobiologie und Genetik

Weitere Mitglieder der Prüfungskommission:

Prof. Dr. Rolf Daniel, Abteilung Genomische und Angewandte Mikrobiologie, Institut für Mikrobiologie und Genetik

Prof. Dr. Stefanie Pöggeler, Abteilung Genetik eukaryotischer Mikroorganismen, Institut für Mikrobiologie und Genetik

PD Dr. Stefan Irniger, Abteilung Molekulare Mikrobiologie und Genetik, Institut für Mikrobiologie und Genetik

JunProf. Dr. Heinz Neumann, Abteilung Molekulare Strukturbiologie, Institut für Mikrobiologie und Genetik

Tag der mündlichen Prüfung: 21.10.2013 


\section{Danksagung}

Zunächst möchte ich meinem Doktorvater PD Dr. Michael Hoppert danken, dass er mir diese anspruchsvolle Aufgabe anvertraut hat und mir damit die Möglichkeit zur Promotion gab. Er ließ mir viel Freiheit beim Forschen, stand mir aber jederzeit mit seinem Rat und anregenden Diskussionen zur Verfügung. Ein besonderer Dank gilt Prof. Dr. Jörg Stülke, nicht nur für die Übernahme des Koreferats, sondern auch für die wohlwollende Begleitung meiner Studienzeit. Prof. Dr. Stefanie Pöggeler, Prof. Dr. Rolf Daniel, JunProf. Dr. Heinz Neumann und PD Dr. Stefan Irniger danke ich für die freundliche Teilnahme an meiner Prüfungskommission. An dieser Stelle möchte ich an den viel zu jung verstorbenen Prof. Dr. Botho Bowien erinnern, der mich während meines Studiums begleitet und inspiriert hat.

Hervorheben möchte ich die außergewöhnlich tolle Zusammenarbeit mit dem Betreuer meiner Diplomarbeit und späteren Arbeitskollegen Dr. Christoph Wrede, es war mir eine Ehre, mit ihm das Labor und das Büro teilen zu dürfen. Auch möchte ich meiner Kollegin Anne Dreier danken, mit der ich zeitgleich in der Arbeitsgruppe Hoppert promovieren durfte. Stellvertretend für all die ehemaligen Mitglieder der Arbeitsgruppe möchte ich mich bei Kevin Neumann und Sandra Lasota bedanken, dass sie mir die Betreuung ihrer Arbeit so leicht wie möglich gemacht haben. Danken möchte ich auch der gesamten Abteilung Allgemeine Mikrobiologie, allen voran Bärbel Herbst, deren Fleiß uns allen eine erfolgreiche Forschungsarbeit erst ermöglicht. Aber auch unseren technischen Assistenten, all den Bachelor- und Masterstudenten und Doktoranden möchte ich für die tolle Atmosphäre, die schönen Feierlichkeiten und die inspirierenden Vorträge während unserer Seminare am frühen Dienstagmorgen danken. Hervorzuheben sind an dieser Stelle Dr. Katrin Gunka und Dr. Arne Schmeisky für ihre aufmunternden und klugen Ratschläge. Stellvertretend für die Mitglieder des BMBFKooperationsprojektes möchte ich mich bei Dr. Paul Schweiger bedanken, der mir die Arbeit mit Gluconobacter oxydans ungemein erleichtert hat. Zum Abschluss gilt mein Dank allen Freunden, Bekannten und all den anderen guten Seelen, die ich die Ehre hatte, kennen lernen zu dürfen. Mein besonderer Dank gilt Eddies Sportstudio, der interstellaren Verbindung zwischen dem Planeten Erde und dem Planeten Uni. Geeignete Worte, um meine Dankbarkeit gegenüber meinen Eltern und meiner Schwester adäquat auszudrücken, kenne ich nicht. Ohne Sie wäre ich nichts. 
"Insane in the membrane Insane in the brain!" Cypress Hill 


\section{Inhaltsverzeichnis}

Abkürzungsverzeichnis.........................................................VI

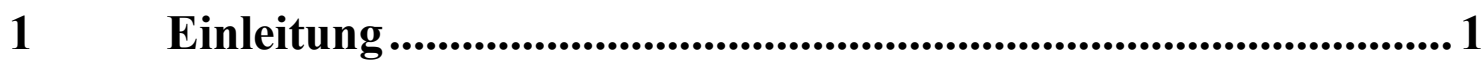

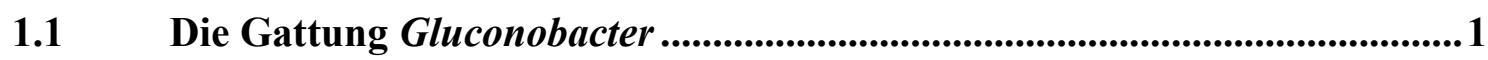

1.2 Der besondere Stoffwechsel von Gluconobacter oxydans ............................2

Essigsäurebakterien in der Biotechnologie...............................................4

1.4 Intracytoplasmatische Membranen, die Cytoplasmamembran und die in dieser Arbeit untersuchten Enzyme...................................................

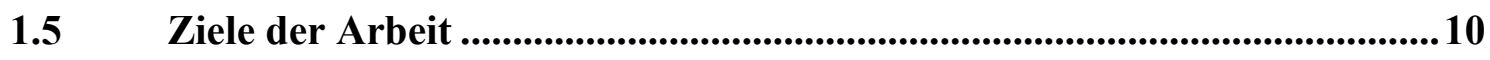

2 Material und Methoden............................................................. 11

2.1 Verwendete Bakterienstämme und Plasmide............................................... 11

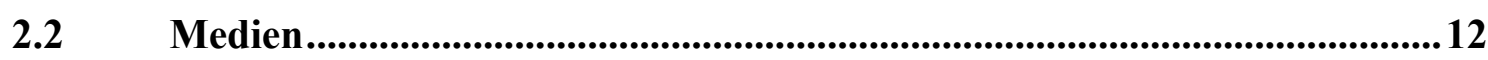

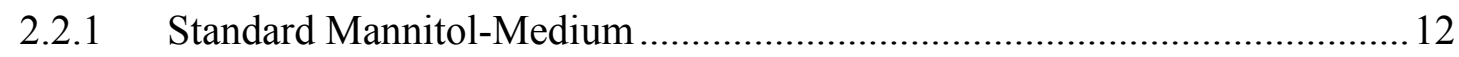

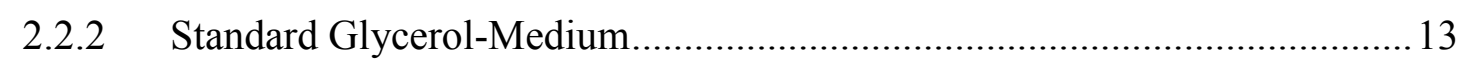

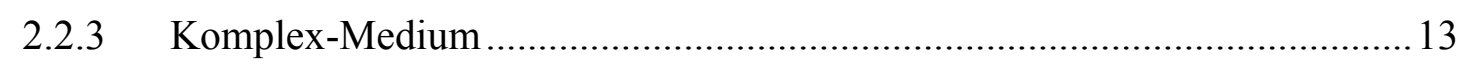

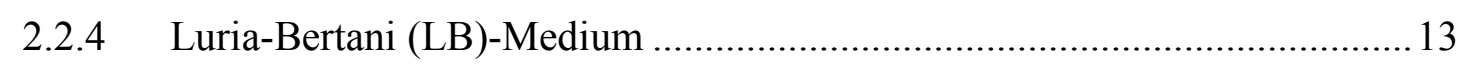

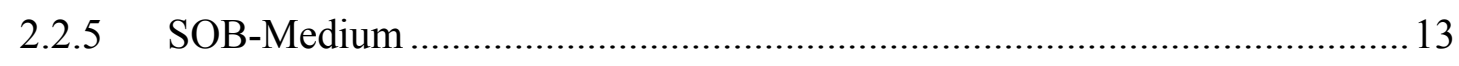

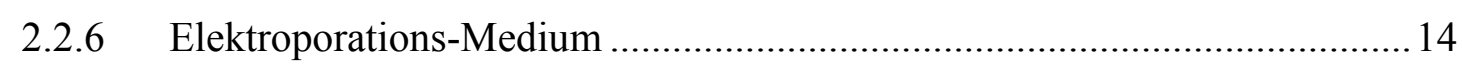

2.2.7 Medienzusätze................................................................................ 14

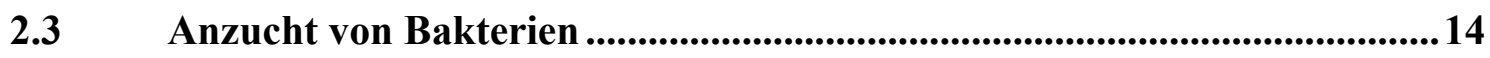

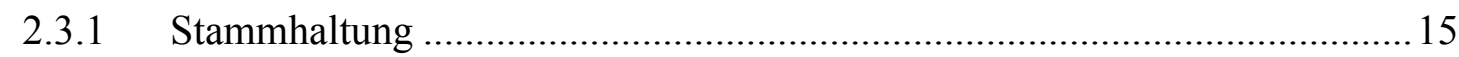

2.3.2 Die Aufnahme von Wachstumskurven ..................................................... 15

2.3.3 Ermittlung der Wachstumsraten und Verdopplungszeiten ........................... 16

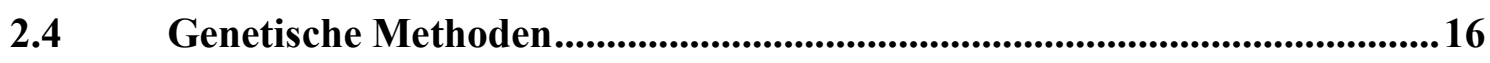

2.4.1 Strategie zur Konstruktion von Plasmiden................................................. 16 


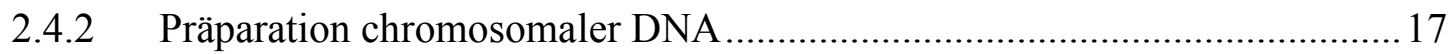

2.4.3 Präparation von Plasmiden und linearisierter DNA .................................... 18

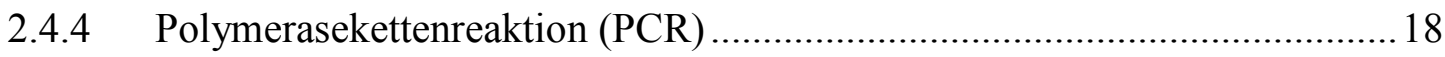

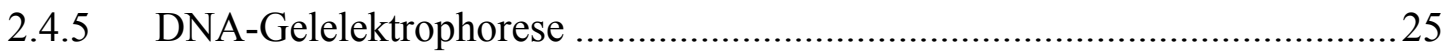

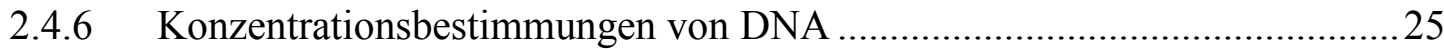

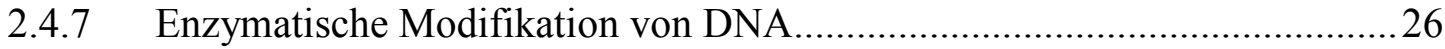

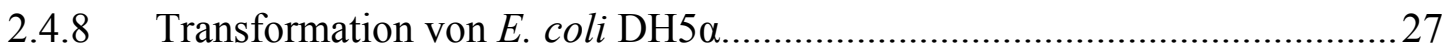

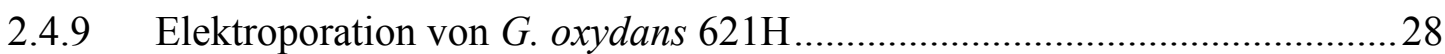

2.4.10 Lösungen für das Arbeiten mit DNA ......................................................... 29

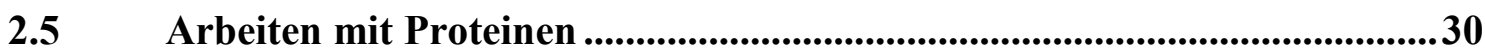

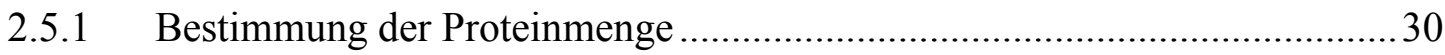

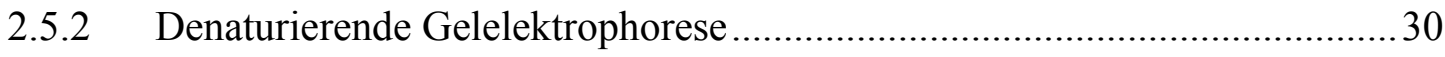

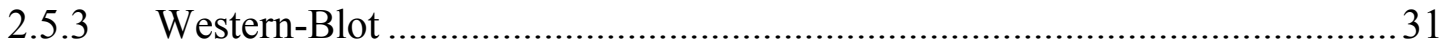

2.5.4 Bestimmung der Aktivität membranständiger Dehydrogenasen ...................33

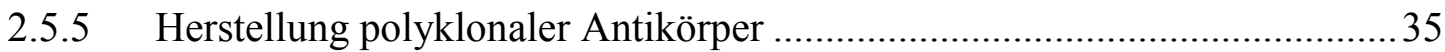

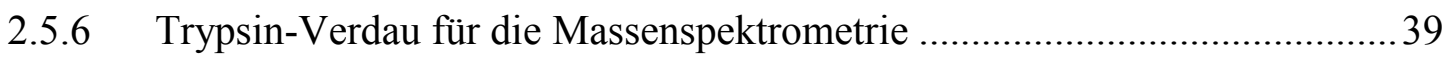

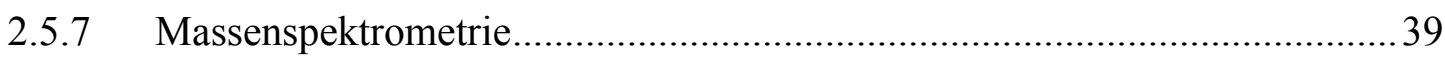

2.5.8 Lösungen zum Arbeiten mit Proteinen ................................................... 40

2.6 Mikroskopie

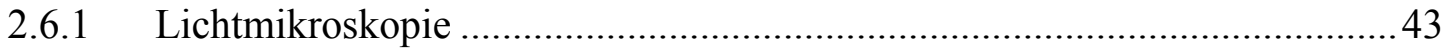

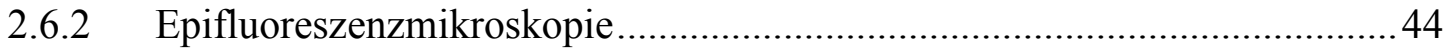

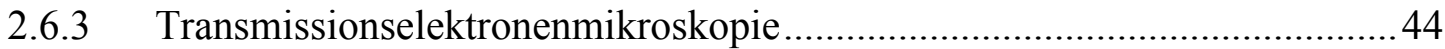

2.6.4 Lösungen zum mikroskopischen Arbeiten ...................................................48

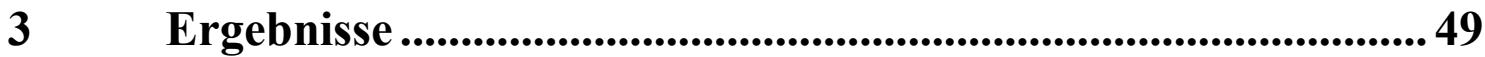

3.1 Die Lokalisation membrangebundener Enzyme in G. oxydans ................. 49

3.1.1 Die Herstellung polyklonaler Antikörper gegen die große Untereinheit der membrangebundenen PQQ-abhängigen Polyol-Dehydrogenase GOX0854

3.1.2 Der Antikörper gegen die große Untereinheit der Quinol-Oxidase des bo3-Typs GOX1912. 
3.1.3 Elektronenmikroskopische Untersuchung des Immunogold-markierten Wildtyps $\quad$. oxydans $621 \mathrm{H}$ und Immunogold-markierter Deletionsmutanten.

3.1.4 Die Lokalisierung der großen Untereinheit der membran-gebundenen PQQ-abhängigen Polyol-Dehydrogenase GOX0854 in Stämmen, die GOX0854/0855 ausschließlich ektopisch exprimieren

3.2 Die Untersuchung der Entwicklung und des Vorkommens intracytoplasmatischer Membranen in G. oxydans 621H ........................60

3.2.1 Differenzierung der Cytoplasmamembran

3.2.2 Untersuchung des Einflusses von Glycerol und Mannitol auf die Quantität von ICM in Abhängigkeit der Wachstumsphasen.

3.3 G. oxydans $621 \mathrm{H}$ bei verringertem Sauerstoffeintrag. 71

3.3.1 Das Wachstum von $G$. oxydans $621 \mathrm{H}$ bei verringertem Sauerstoffeintrag . 71

3.3.2 Die Enzymaktivität von $G$. oxydans $621 \mathrm{H}$ bei verringertem Sauerstoffeintrag .72

3.3.3 Detektion der großen Untereinheit der membrangebundenen PQQabhängigen Polyol-Dehydrogenase GOX0854 an Proben des Wildtyps G. oxydans $621 \mathrm{H}$ und der Deletionsmutante G. oxydans $\Delta$ upp Sgox1911-1914 bei verringertem Sauerstoffeintrag ....

3.3.4 Detektion/Lokalisierung der großen Untereinheit der Quinol-Oxidase des bo3-Typs GOX1912 und der Deletionsmutante G. oxydans $621 \mathrm{H}$

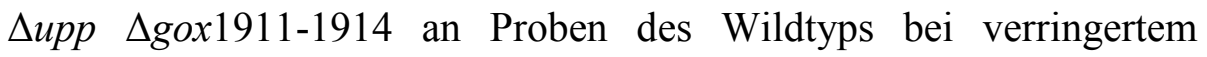
Sauerstoffeintrag

3.4 Das Monitoring membranständiger Dehydrogenasen mit fluoreszierenden membranständigen Fusionsproteinen

3.4.1 Die Fusion eines auf Flavinmononukleotid basierenden fluoreszierenden Proteins mit einer membranständigen PQQabhängigen Dehydrogenase .81

3.4.2 Die Expression von evoglowPp1 in G. oxydans $621 \mathrm{H}$ 82

3.4.3 Die Konstruktion des Fusionsproteins aus GOX1441 und evoglowPp1 und dessen Expression in G. oxydans $621 \mathrm{H}$ 
3.5.1 Wachstumsraten und Verdopplungszeiten des Wildtyp G. oxydans $621 \mathrm{H}$

3.5.2 Wachstumsraten und Verdopplungszeiten genetisch veränderter Stämme von G. oxydans $621 \mathrm{H}$

4 Diskussion 96

4.1 Die Lokalisation membrangebundener Enzyme in G. oxydans 97

4.1.1 Der polyklonale Antikörper gegen die große Untereinheit der membrangebundenen PQQ-abhängigen Polyol-Dehydrogenase GOX0854

4.1.2 Der polyklonale Antikörper gegen die große Untereinheit der membrangebundenen Quinol-Oxidase des bo3-Typs GOX1912 100

4.1.3 Die Lokalisierung der großen Untereinheit der membran-gebundenen PQQ-abhängigen Polyol-Dehydrogenase GOX0854 in Stämmen, die GOX0854/0855 ausschließlich ektopisch exprimieren

4.2 Die Untersuchung der Entwicklung und des Vorkommens intracytoplasmatischer Membranen in G. oxydans 621H .........................105

4.2.1 Die Differenzierung der Cytoplasmamembran .......................................... 106

4.2.2 Das Vorkommen der ICM - Abhängig von Wachstumsphasen, Substrat und deren Konzentration 108

4.2.3 Der Einfluss der Wachstumsparameter auf die ICM-Bildung 110

4.3 Intracytoplasmatische Membranen, spezifische Enzymaktivitäten membranständiger Dehydrogenasen und die Expression der PolyolDehydrogenase - eine nähere Betrachtung

4.3.1 Besteht ein direkter Zusammenhang zwischen ICM-Menge und spezifischer Aktivität membranständiger Dehydrogenasen?

4.3.2 Besteht ein direkter Zusammenhang zwischen Substratkonzentration und spezifischer Aktivität membranständiger Dehydrogenasen? 116

4.4 G. oxydans $621 \mathrm{H}$ bei verringertem Sauerstoffeintrag 
4.4.1 Die Enzymaktivität PQQ-abhängiger, membranständiger

Dehydrogenasen gegenüber dem Substrat Ethanol ................................... 120

4.4.2 Die Rolle der Quinol-Oxidase des bo3-Typs GOX1911-1914 _.................. 122

4.5 ICM in G. oxydans und ihr Potential in der Biotechnologie ......................124

4.6 Das Monitoring membranständiger Dehydrogenasen mit fluoreszierenden membranständigen Fusionsproteinen .........................128

4.6.1 Die Expression von FbFP in G. oxydans unter der Kontrolle der drei verschiedenen Promotoren

4.6.2 Die Konstruktion des Fusionsproteins aus GOX 1441 und des FbFP evoglowPp1 und die Expression in G. oxydans.....

$5 \quad$ Zusammenfassung

6 Literaturverzeichnis.

$7 \quad$ Anhang

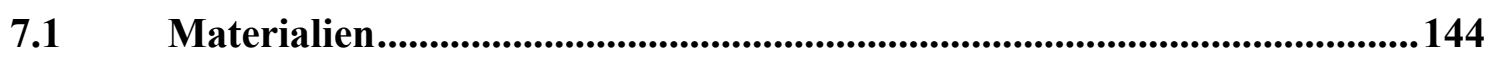

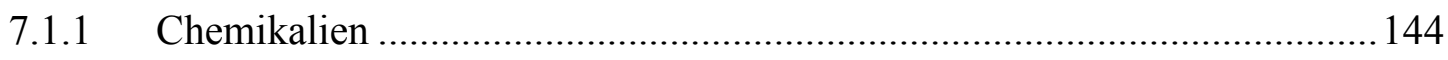

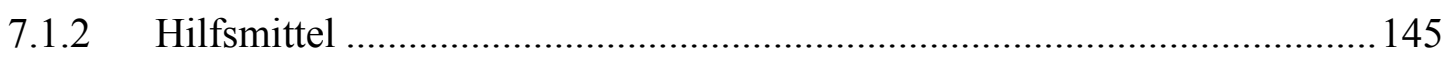

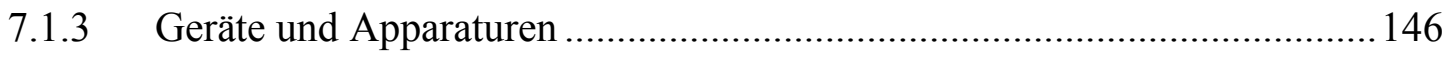

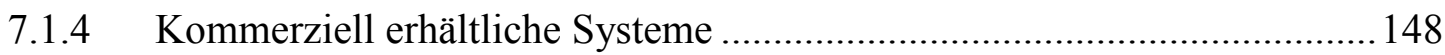

7.1.5 Enzyme und Proteine …................................................................ 148

7.2 Verwendete Internetangebote und Computerprogramme .........................149

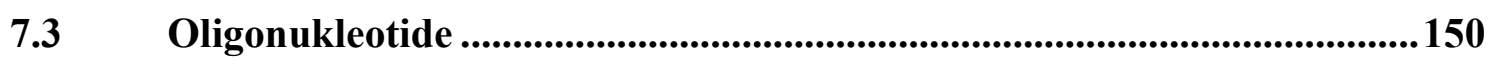

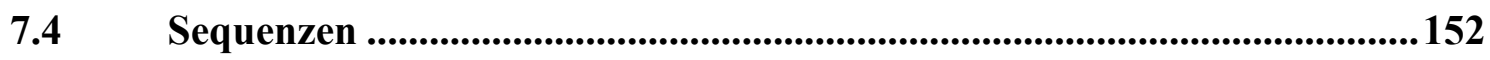

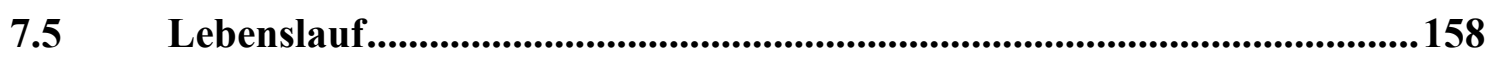




\section{Abkürzungsverzeichnis}

$\%(\mathrm{v} / \mathrm{v})$

$\%(\mathrm{w} / \mathrm{v})$

Abb.

AG

APS

APS

ATCC

Bp

Bzw.

$B S A$

${ }^{\circ} \mathrm{C}$

Ca.

CCD

CHAPS

CIAP

$\mathrm{CM}$

$\mathrm{Cm}$

d

$\mathrm{Da}$

DCPIP

DHA

D. h.

DMSO

DNA

DSMZ

EDTA

Et al.

Escherichia coli

EM
$\%$ (volume/volume) Volumenanteil

$\%$ (weight/volume) Massenkonzentration

Abbildung, Abbildungen

Arbeitsgruppe

Adenosin-5'-Phosphosulfat

Ammoniumperoxodisulfat

American Type Culture Collection

Basenpaare

Beziehungsweise

Bovine serum albumin, Rinderalbumin

Grad Celsius

Circa

Charge-coupled device

3-[(3-Cholamidopropyl)dimethylammonio]-1-

propanesulfonate

Calf intestine alkaline phosphatase, Alkalische Phosphatase aus dem Darminhalt von Kälbern

Cytoplasmamembran

Zentimeter

Tag/Tage

Dalton (Atomare Masseneinheit)

Dichlorphenolindophenol

Dihydroxyaceton

Das heißt

Dimethylsulfoxid

Desoxyribonuklein-Acid

Deutsche Sammlung von Mikroorganismen und

Zellkulturen

Ethylendiamintetraacetat

Et alia (und andere)

E. coli

Elektronenmikroskop/Elektronenmikroskopie 


\begin{tabular}{|c|c|}
\hline Evtl. & Eventuell \\
\hline Exp. & exponentiell \\
\hline Fa. & Firma \\
\hline $\mathrm{FbFP}$ & Flavinmononukleotid basierendes fluoreszierendes Protein \\
\hline FMN & Flavinmononucleotid \\
\hline FZ & Forschungszentrum \\
\hline Ggf. & Gegebenenfalls \\
\hline g & Erdbeschleunigung $\left(9,81 \mathrm{~m} / \mathrm{s}^{2}\right)$ \\
\hline Gox & Gluconobacter oxydans \\
\hline G. oxydans & Gluconobacter oxydans \\
\hline $\mathrm{h}$ & Stunde(n) \\
\hline HABA & Hydroxy-Azophenyl-Benzoesäure \\
\hline $\mathrm{HCl}$ & Chlorwasserstoffsäure (Salzsäure) \\
\hline HEPES & 2-(4-(2-Hydroxyethyl)- 1-piperazinyl)-ethansulfonsäure \\
\hline \multirow[t]{2}{*}{ HPLC } & high performance liquid chromatography \\
\hline & (Hochleistungsflüssigkeitschromatographie) \\
\hline I. d. R. & In der Regel \\
\hline $\operatorname{IgG}$ & Immunglobulin G oder Gammaglobulin \\
\hline Inkl. & Inklusive \\
\hline $\mathrm{K}$ & Kilo \\
\hline Kap. & Kapitel, Kapiteln \\
\hline $\mathrm{Kbp}$ & Kilo-Basenpaaren \\
\hline $\mathrm{L}$ & Liter \\
\hline $\log$ & logarithmisch \\
\hline M & Molar, Mol/Liter \\
\hline $\mathrm{m}$ & Milli $\left(10^{-3}\right)$ \\
\hline Max. & $\operatorname{Maximal}(\mathrm{e})$ \\
\hline $\mathrm{Mb}$ & Megabasenpaare \\
\hline $\mathrm{mM}$ & Millimolar $[\mathrm{mmol} / \mathrm{ml}]$ \\
\hline$\lambda$ & Lambda, Wellenlänge \\
\hline $\min$ & Minute(n) \\
\hline Mind. & Mindestens \\
\hline Mod. & Modifiziert \\
\hline mRNA & messenger ribonucleic acid (Boten-Ribonukleinsäure) \\
\hline
\end{tabular}




\begin{tabular}{|c|c|}
\hline Mw & molecular weight (Molekulargewicht) \\
\hline MWCO & Molecular weight cut off (molekulare Ausschlussgröße) \\
\hline$\mu \mathrm{F}$ & Mikro Farad (Elektrische Kapazität) \\
\hline$\mu$ & Mikro $\left(10^{-6}\right)$ \\
\hline$\mu$ & Max. Wachstumsrate \\
\hline NADP & Nicotinsäureamid-Adenin-Dinukleotid-Phosphat \\
\hline NCBI & National Center for Biotechnology Information \\
\hline NEB & New England Biolabs \\
\hline OEPCR & Overlap Extension PCR \\
\hline OD & Optische Dichte \\
\hline$\Omega$ & Ohm (Elektrischer Widerstand) \\
\hline PBS & Phosphate bufferd saline, Phosphat-gepufferte Saline \\
\hline PCR & Polymerase chain reaction, Polymerase Kettenreaktion \\
\hline PMS & Phenazinmethosulfat \\
\hline PQQ & Pyrroloquinolin quinone, Pyrrolochinolinchinon \\
\hline psi & Pound-force per square inch, Pfund pro Quadratzoll \\
\hline rDNA & Ribosomale Desoxyribonuklein-Acid \\
\hline Resp. & Respektive \\
\hline RT & Raumtemperatur \\
\hline $\mathrm{s}$ & Sekunde(n) \\
\hline SDS & Sodium dodecyl sulfate, Natriumdodecylsulfat \\
\hline Sog. & Sogenannte \\
\hline Sp. & Spezies der angegebenen Gattung \\
\hline Spp. & species pluralis, mehrere Spezies einer Gattung \\
\hline Ssp. & Subspezies (Unterart) \\
\hline Stat. & Stationär \\
\hline Strep & Streptavidin \\
\hline Tab. & Tabelle \\
\hline TAE & Tris-Acetat-EDTA \\
\hline Tag & Markierung \\
\hline $\operatorname{Taq}$ & Thermus aquaticus \\
\hline TEM & Transmissions-Elektronenmikroskopie \\
\hline$t_{d}$ & Verdopplungszeit \\
\hline TEMED & $\mathrm{N}, \mathrm{N}, \mathrm{N}^{\prime}, \mathrm{N}^{\prime}$-Tetramethylethylendiamin \\
\hline
\end{tabular}




$\begin{array}{ll}\text { Tris } & \text { Tris-(hydroxymethyl)-aminomethan } \\ \text { TU } & \text { Technische Universität } \\ \text { U } & \text { Einheit der Enzymaktivität (Unit) } \\ \text { U. a. } & \text { Unter anderem } \\ \text { UE } & \text { Untereinheit } \\ \text { Univ. } & \text { Universität } \\ \text { Upm } & \text { Umdrehungen pro Minute } \\ \text { Upp } & \text { Uracil Phosphoribosyltransferase } \\ \text { U. U. } & \text { Unter Umständen } \\ \text { V } & \text { Volt (Elektrische Spannung) } \\ \text { ZAP } & \text { Zellaufschluss-Puffer } \\ \text { Z. B. } & \text { Zum Beispiel }\end{array}$

\section{Nukleotidbasen}
A
Purinbase Adenin
G
Purinbase Guanin
C
Pyrimidinbase Cytosin
$\mathrm{T}$
Pyrimidinbase Thymidin

\section{Aminosäuren}

$\begin{array}{llll}\text { A } & \text { Alanin } & \text { G } & \text { Glycin } \\ \text { M } & \text { Methionin } & \text { S } & \text { Serin } \\ \text { C } & \text { Cystein } & \text { H } & \text { Histidin } \\ \text { N } & \text { Asparagin } & \text { T } & \text { Threonin } \\ \text { D } & \text { Aspartat } & \text { I } & \text { Isoleucin } \\ \text { P } & \text { Prolin } & \text { V } & \text { Valin } \\ \text { E } & \text { Glutamat } & \text { K } & \text { Lysin } \\ \text { Q } & \text { Glutamin } & \text { W } & \text { Tryptophan } \\ \text { F } & \text { Phenylalanin } & \text { L } & \text { Leucin } \\ \text { R } & \text { Arginin } & \text { Y } & \text { Tyrosin }\end{array}$




\section{Einleitung}

Gluconobacter oxydans besitzt schon heute eine große Bedeutung in der Biotechnologie (DE MUYNCK, 2007), doch um das volle Potential dieses speziellen Organismus auszuschöpfen bedarf es weiterer Forschung. Gegenstand der vorliegenden Arbeit sind intracytoplasmatische Membranen (CLAUS et al., 1975) und die in der Cytoplasmamembran lokalisierten enzymatischen Systeme, die zur unvollständigen Oxidation von Zuckern, Alkoholen und weiteren Kohlenwasserstoff-Verbindungen beitragen (MATSUSHITA et al., 1994). Im Rahmen dieser Einleitung wird zunächst die Gattung Gluconobacter vorgestellt und anschließend die Art G. oxydans und ihr besonderer Stoffwechsel beleuchtet. Das Potential von Essigsäurebakterien in der Biotechnologie ist ein weiteres Thema, bevor auf den Kern dieser Arbeit, die intracytoplasmatischen Membranen, die Cytoplasmamembran und die in dieser Arbeit untersuchten Enzyme eingegangen wird. Eine Zusammenfassung der Ziele der Arbeit schließt diese Einleitung ab.

\subsection{Die Gattung Gluconobacter}

Arten der Gattung Gluconobacter sind Mitglieder der Acetobacteraceae-Familie und somit Gram-negative Alphaproteobacteria. Alle Acetobacteraceae sind obligat aerob und wachsen mit Sauerstoff als terminalem Elektronenakzeptor. Die Zellen sind i. d. R. stäbchenförmig bis ellipsoid, 0,5 bis $1,0 \times 2,6$ bis $4,2 \mu \mathrm{m}$ groß und können durch 3 bis 8 polar inserierte Flagellen beweglich sein. Es können auch von der Stäbchenform abweichende unförmige Zellformen auftreten. Sie liegen einzeln, paarweise oder in kurzen Ketten vor, Endosporen werden nicht gebildet. Die optimalen Wachstumsbedingungen liegen bei einer Temperatur zwischen 25 bis $30^{\circ} \mathrm{C}$ und einem pH-Wert von 5,0 bis 6,0 (SIEVERS und SWINGS, 2005). Die Gattung Gluconobacter wurde 1935 zum ersten Mal von T. Asai erwähnt, als er aerob lebende Bakterien auf Früchten untersuchte und ihm ihre eingeschränkte Möglichkeit des Umsatzes von Ethanol zu Essigsäure, aber auch ihre ausgeprägte Fähigkeit zur Umsetzung von Glucose zu Gluconsäure auffiel (ASAI, 1935). Im Gegensatz zu den anderen Gattungen dieser Familie Acetobacter, Acidomonas, Asaia, Gluconacetobacter, und Kozakia, den Peroxidierern, können Gluconobacter-Arten Acetat nicht zu $\mathrm{CO}_{2}$ und $\mathrm{H}_{2} \mathrm{O}$ oxidieren, da 
sie keinen vollständigen Citrat-Zylus besitzen (KERSTERS et al., 2006). Gluconobacter spp., den Suboxidierern, fehlt die Succinat-Dehydrogenase; Acetat oder Essigsäure ist somit das Endprodukt der unvollständigen Oxidation (GREENFIELD und CLAUS, 1972). Dennoch sind Gluconobacter-Arten in der Essigherstellung nicht die hauptverantwortlichen Bakterien für die Essigsäure. Zum einen ist die membranständige Alkohol-Dehydrogenase (ADH) bei Acetobacter spp. stabiler als die der Gluconobacter spp. (RASPOR und GORANOVIČ, 2008), zum anderen setzen Gluconobacter spp. Ethanol langsamer zu Acetat um als Acetobacter spp.. Dennoch leistet Gluconobacter oxydans durch die Produktion von Aromastoffen wie Gluconsäuren einen wichtigen Beitrag zur Essigherstellung (DE MUYNCK et al., 2007). Im Gegensatz zu den Gattungen Acetobacter und Gluconacetobacter bevorzugen Gluconobacter spp. zuckerstatt alkoholreiche Standorte, wie Früchte, Blüten, Wein, Bier und Limonaden (SIEVERS und SWINGS, 2005). Sogar in Honigbienen konnten GluconobacterStämme nachgewiesen werden (LAMBERT et al., 1980). Essigsäurebakterien galten lange als nicht-pathogene Mikroorganismen, wenn man von ihrer Eigenschaft absieht, Früchte zu verderben (DE MUYNCK et al., 2007). Im Jahre 2004 wurde in der Arbeit von SNYDER et al. Asaia bogorensis als Auslöser einer schwer behandelbaren Bauchfellentzündung identifiziert. Als verantwortlich für die chronische granulomatöse Erkrankung einiger Patienten konnten GREENBERG et al. (2006) ein mit den Essigsäurebakterien verwandtes Bakterium nachweisen. Aus den Lungen zweier Mukoviszidose-Patienten wurden von ALAUZET et al. (2010) ein Asaia- und vier Gluconobacter-Isolate gewonnen, die als multiresistente, opportunistische Humanpathogene eingestuft worden sind.

\subsection{Der besondere Stoffwechsel von Gluconobacter oxydans}

Die Abbauwege von Kohlenhydraten oder Alkoholen durch G. oxydans folgen zwei unterschiedlichen Strategien. Es gibt deren schnelle, verschwenderisch erscheinende Oxidation durch Dehydrogenasen im Periplasma, was in erster Linie der Energiegewinnung und der Etablierung am Standort dient. Dem gegenüber steht die Aufnahme der Substrate in die Zelle, wo sie zur Energiegewinnung und zum Aufbau von Biomasse genutzt werden.

Das Genom von G. oxydans ATCC 621H wurde 2005 von PRUST et al. komplett sequenziert. Dabei konnte bestätigt werden, dass der Tricarbonsäurezyklus 
unvollständig ist, da die Succinat-Dehydrogenase fehlt. Unterbrochen sind sowohl der Embden-Meyerhof-Weg durch das Fehlen der Phosphofruktokinase, als auch die Gluconeogenese durch das Fehlen der Phosphoenolpyruvat-Synthetase oder anderer Phosphoenolpyruvat-sythetisierender Enzyme. Der Aufbau von Glucose aus Pentosen oder Glycerol muss über den oxidativen Teil des Pentosephosphatwegs (PPW) erfolgen, der als der wichtigste Stoffwechselweg in G. oxydans für den Abbau von Kohlehydraten innerhalb der Zelle gilt. Es sind jedoch auch alle Gene für den Entner-Duodoroff-Weg (EDW) in G. oxydans $621 \mathrm{H}$ vorhanden (PRUST et al., 2005). In den Arbeiten von RICHARDT et al. (2012) wurde gezeigt, dass weder der EDW noch der PPW essentiell sind. Letzterer scheint jedoch für das Wachstum von $G$. oxydans $612 \mathrm{H}$ wichtiger zu sein, darüber hinaus führt die Unterbrechung des EDW sogar zu einem verbesserten Wachstum. Verschiedenste Zucker, Alkohole und deren Derivate können von G. oxydans in die Zelle über einen der Zucker-Protonen-Symporter, ZuckeraufnahmeABC-Transporter oder eine andere Zuckerpermease aufgenommen werden (PRUST et al., 2005; DEPPENMEIER und EHRENREICH, 2009).

In den von $G$. oxydans bevorzugten zuckerreichen Habitaten ist es für den Organismus von Vorteil, die gut verwertbaren Kohlenstoffquellen wie z. B. Glucose oder Fructose schnell umzusetzen, um damit gegenüber weniger spezialisierten Organismen im Vorteil zu sein. Zuckersäuren senken den pH-Wert in der Umgebung und sind ebenso wie Keto-Zucker nicht für alle Mikroorganismen gut zugänglich (DEPPENMEIER und EHRENREICH, 2009). Sind diese primären Kohlenstoffquellen im Überfluss vorhanden, werden unvollständige Oxidationen durch in der Cytoplasmamembran oder im Periplasma lokalisierte Dehydrogenasen durchgeführt. Da sich die aktiven Zentren der Dehydrogenasen in beiden Fällen im Periplasma befinden, müssen die Substrate nicht in die Zelle aufgenommen werden und die oxidierten Produkte können in die Umgebung der Zelle diffundieren. Die bei der Oxidation freiwerdenden Elektronen gelangen via PQQ-, NADPH-, Flavin- und/oder Häm c-haltigen Coenzyme in den Ubichinon-Pool (DEPPENMEIER et al., 2002) und können von dort auf eine QuinolOxidase des bo3-Typs übertragen werden, die Sauerstoff zu Wasser reduziert (MATSUSHITA et al., 1987). Dabei wird ein Protonengradient erzeugt, der über eine $\mathrm{F}_{\mathrm{o}} \mathrm{F}_{1}$-ATPase zur Generierung von ATP genutzt wird (PRUST et al., 2005). Es gibt noch eine weitere Quinol-Oxidase des bd-Typs, die bei einem niedrigen $\mathrm{pH}-$ Wert exprimiert wird und nur einen geringen Protonengradienten erzeugt (DEPPENMEIER und EHRENREICH, 2009). Der Energiegewinn dieser schnellen Umsetzung ist nicht 
sehr groß und die Zunahme an Biomasse ist entsprechend gering. Wenn ein Substrat jedoch nahezu vollständig umgesetzt ist, kann das Produkt weiter oxidiert werden. Gluconat, das Produkt der Glucose-Oxidation durch eine membranständige, PQQabhängige Dehydrogenase (DEPPENMEIER et al., 2002) wird erst dann weiter zu Ketogluconat oxidiert, wenn ca. drei Viertel der vorhandenen Glucose bereits umgesetzt sind (WEENK et al., 1984). Glucose, Gluconat und Ketogluconat können jederzeit über Transporter in die Zelle aufgenommen werden (HÖLSCHER et al., 2009), wenngleich der PPW durch höhere Glucose-Konzentrationen inhibiert zu werden scheint (OLIJVE und KOK, 1979). Das Produkt der Oxidation von Fructose durch eine membranständige, PQQ-abhängige Fructose-Dehydrogenase ist 5-Keto-D-Fructose (DEPPENMEIER et al., 2002). Die Ketose kann von G. oxydans über eine Permease in die Zelle aufgenommen werden, wo diverse Kinasen, Epimerasen und Isomerasen viele Substrate für den Intermediärstoffwechsel von G. oxydans zugänglich machen können (PRUST et al., 2005; DEPPENMEIER und EHRENREICH, 2009). 5-Keto-D-Fructose wird im Cytosol durch die 5-Keto-D-Fructose-Reduktase NADPH-abhängig wieder zurück zu Fructose reduziert und in den Pentose-Phosphatweg eingeschleust (MATSUSHITA et al., 1994). Interessanterweise fehlt $G$. oxydans $621 \mathrm{H}$ eine membranständige, PQQ-abhängige Fructose-Dehydrogenase (PRUST et al., 2005). Fructose wird in diesem Fall in die Zelle aufgenommen, bis zum Acetat katabolisiert und in das umgebende Medium abgegeben (PETERS et al. 2013). Bei Oxidationsreaktionen vieler intrazellulärer Dehydrogenasen entsteht $\mathrm{NADPH}+\mathrm{H}^{+}$, welches durch eine $\mathrm{NAD}^{+}$-abhängige Transhydrogenase wieder regeneriert wird. Darüber hinaus schleust diese Transhydrogenase Protonen über die Cytoplasmamembran in das Periplasma (PRUST et al., 2005). Es wird außerdem vorgeschlagen, dass wiederum das NADH durch eine membrangebundene Typ-II NADH-Dehydrogenase oxidiert wird und die Elektronen via Ubichinol auf die QuinolOxidase des bo3-Typs übertragen werden (DEPPENMEIER und EHRENREICH, 2009). Durch diese beiden Protonen-translozierenden Prozesse wäre die intrazelluläre Oxidation von Substraten am Aufbau eines Protonengradienten beteiligt.

\subsection{Essigsäurebakterien in der Biotechnologie}

Bakterien, die Ethanol zu Essigsäure oxidieren, werden gemeinhin als Essigsäurebakterien bezeichnet (RASPOR und GORANOVIČ, 2008). Die Herstellung von Essig 
aus Ethanol ist die wohl am längsten etablierte biotechnologische Nutzung von Essigsäurebakterien. Wahrscheinlich ist, dass seit den Anfängen der Kelterung von Wein auch Essig bekannt ist. Auf eine ähnlich lange Tradition kann auch der Genuss von Kombucha zurückblicken, ein Getränk aus fermentiertem gesüßtem Tee, zu dessen Herstellung neben Hefen auch Essigsäurebakterien wie Gluconobacter spp. beitragen. Gleiches gilt für Kakao, der ohne einen Fermentationsprozess sein gewünschtes Aroma nicht bekäme. Hierfür sind hauptsächlich Acetobacter spp. und Milchsäurebakterien verantwortlich, es wurden aber auch Gluconobacter spp. nachgewiesen (RASPOR und GORANOVIČ, 2008). In diesen drei genannten Beispielen führen die verschiedenen Standorte und regional unterschiedliche Methoden $\mathrm{zu}$ variierenden Lebensgemeinschaften von Mikroorganismen, die zu der geschmacklichen Diversität der Lebensmittel beitragen.

Heutzutage hat sich Gluconobacter oxydans als einer der meist genutzten Mikroorganismen in der industriellen Biotechnologie etabliert (DE MUYNCK et al., 2007). Ein breites Spektrum an Substraten wie Alkohole, Zucker oder Zuckersäuren werden unvollständig oxidiert, manche $\mathrm{zu}$ wirtschaftlich interessanten Produkten. Vorteilhaft ist, dass z. B. viele Ketosen durch diese Biokonversionen aus Polyolen stereo- und regioselektiv erzeugt werden. Dies geschieht im Periplasma der Zelle, sodass sich das Produkt im umgebenden Medium anhäuft (RASPOR und GORANOVIČ, 2008). Die Herstellung von Vitamin C, oder L-Ascorbinsäure erreichte 2002 einen Umfang von 80.000 Tonnen. Vitamin C hat eine antioxidative Wirkung und stellt ein wichtiges Coenzym für die Prolyl-4-Hydroxylase dar, die bei der Biosynthese des Kollagens benötigt wird (BERG, 2003). L-Sorbose, das günstigste L-konfigurierte Intermediat der Synthese von Vitamin C, wurde im Jahr 2002 in großindustriellem Maßstab von 60.000 Tonnen durch die Biokonversion von D-Sorbitol zu L-Sorbose durch G. oxydans produziert (DE MUYNCK et al., 2007). Dies ist Teil des bis heute meistgenutzten und bereits 1934 von Reichstein und Grüssner publizierten Verfahrens der synthetischen Vitamin C-Herstellung. Derzeit wird versucht, weitere Schritte der Reichstein-Synthese durch Mikroorganismen durchführen zu lassen, u. a. in G. oxydans. Es wurde bereits ein Stamm entwickelt, der Sorbitol zu 2-keto-L-gulonsäure oxidiert (SAITO et al., 1998), welche letztendlich der Reichstein-Synthese entsprechend mit verdünnter Säure zu L-Ascorbinsäure umgesetzt wird (REICHSTEIN und GRÜSSNER, 1934). 
Von der vielseitig verwendbaren D-Gluconsäure werden pro Jahr ca. 100.000 Tonnen hergestellt (DE MUYNCK et al., 2007). Es wird in der Lebensmittel-, Pharma-, und Textilindustrie eingesetzt, dient zum Reinigen und sogar als Zementzusatz, um diesen widerstandsfähiger und stabiler zu machen (SINGH und KUMAR, 2007). Zurzeit wird D-Gluconsäure hauptsächlich durch den Ascomycet Aspergillus niger produziert, es entsteht durch die Dehydrogenierung von D-Glucose zu Glucono- $\delta$-Lacton und dessen anschließender spontanen Hydrolyse. Traubenmost oder Molke dienen hierbei als Ausgangssubtrat. Dem Vorteil von Pilzen, auch noch bei relativ hohen Zuckerkonzentrationen zu wachsen, steht ihr im Vergleich zu Mikroorganismen engeres Substratspektrum gegenüber. Darüber hinaus ist die Mycelbildung unvorteilhaft (SINGH und KUMAR, 2007), wohingegen G. oxydans neben einer geringen Biomassebildung (DEPPENMEIER et al., 2002) die Produkte der unvollständigen Oxidationen in das umgebende Medium abgibt und somit die Kosten für deren Aufreinigung senkt (MACAULEY et al., 2001). Die Fähigkeit von Mikroorganismen, auf Substraten wie Melasse, Abfällen aus der Lebensmittelindustrie oder aufbereitetem Altpapier zu wachsen könnte ebenfalls dazu beitragen, die Kosten für die Produktion von D-Gluconsäure oder deren Salze und Derivate zu senken (SINGH und KUMAR, 2007). G. oxydans kann Glucose durch die membranständige, PQQ-abhängige GlucoseDehydrogenase regio- und stereoselektiv zu D-Gluconsäure oxidieren, bis keine Glucose mehr verfügbar ist (HÖLSCHER et al., 2009). Die D-Gluconsäure wird anschließend zu 5-Keto-D-Gluconsäure oxidiert, welche als Vorläufersubstanz für die Synthese von Isoascorbin- und Weinsäure für die industrielle Weiterverarbeitung interessant sind (DEPPENMEIER et al., 2002).

In der Produktion des Süßstoffs D-Tagatose führt die Biokonversion von D-Galactitol durch G. oxydans zu den besten Resultaten (RASPOR und GORANOVIČ, 2008). Glycerol wird durch die membrangebundene, PQQ-abhängige Polyoldehydrogenase von G. oxydans zu Dihydroxyaceton oxidiert, das in Selbstbräunern Verwendung findet (DE MUYNCK et al., 2007). Shikimisäure ist ein wichtiges Zwischenprodukt für die Aminosäuresynthese, aber auch die Vorläuferverbindung von Oseltamivir, einem häufig eingesetzten antiviralen Wirkstoff. Shikimisäure ist mit herkömmlichen Methoden aus der organischen Chemie nur sehr aufwendig darzustellen. Zurzeit wird versucht, mit mehreren Enzymen aus G. oxydans Shikimisäure aus Chinasäure zu synthetisieren (RASPOR und GORANOVIČ, 2008; DE MUYNCK et al., 2007). 
Biosensoren sind immobilisierte biologisch aktive Systeme wie Antikörper, Enzyme, Organelle oder Mikroorganismen, gekoppelt an einen Signalumwandler und einem elektronischen Verstärker. Das immobilisierte biologische System tritt in Wechselwirkung mit der $\mathrm{zu}$ analysierenden Probe. Dabei kommt es zu physikochemischen Veränderungen, welche mittels des Transduktors, wie z. B. amperometrischen und potentiometrischen Elektroden bestimmt werden können (RASPOR und GORANOVIČ, 2008). In Kaliumphosphat-Puffer gelöst, sind mit immobilisierten Zellen von $G$. oxydans Ethanol, Glycerol und Glucose in Konzentrationen von bis $\mathrm{zu} 0,05 \mathrm{mM}$, sowie Xylitol bis $\mathrm{zu} 0,5 \mathrm{mM}$ detektierbar (RESHETILOV et al. 1998).

\subsection{Intracytoplasmatische Membranen, die Cytoplasmamembran und die in dieser Arbeit untersuchten Enzyme}

Bevor intracytoplasmatische Membranen (ICM) in Gluconobacter oxydans von BATZING und CLAUS (1973) zum ersten Mal beschrieben wurden, waren solche Strukturen bereits für photosynthetische sowie nitrifizierende Bakterien bekannt (VATTER und WOLFE, 1958; MURRAY und WATSON, 1965). Die ersten beschriebenen heterotrophen Mikroorganismen mit ICM waren Pseudomonaden und Methan-oxidierende Bakterien (WYSS et al., 1961; DAVIES und WHITTENBURRY, 1970). Den in Escherichia coli beschriebenen ICM wurde zunächst eine Rolle in der Zellteilung zugeschrieben (COTA-ROBLES, 1966; PONTEFRACT, 1969). Dabei schien es sich aber um Artefakte der chemischen Fixierung der Zellen, den sog. „Mesosomen“ zu handeln. Diese boten einige Zeit Grund für die Annahme, dass auch Gram-positive Bakterien ICM enthalten können (SILVA et al. 1976; DUBOCHET, 1983).

Es gibt Grund zu der Annahme, dass ICM aus der Cytoplasmamembran durch deren Invagination hervorgehen. Dies wird für nitrifizierende Bakterien so vermutet (MURRAY und WATSON, 1965) und im Falle von Methan-oxidierenden Bakterien konnte es wiederholt gezeigt werden (DAVIES und WHITTENBURRY, 1970; SCOTT et al., 1981). Ferner wurde für Mikroorganismen die zur Photosynthese befähigt sind auch eine unabhängige Synthese diskutiert, die teilweise an der Cytoplasmamembran stattfindet (OELZE und DREWS, 1971). Im Falle der Pseudomonadaceae Azotobacter vinelandii geht aus elektronenmikroskopischen Untersuchungen hervor, dass dessen 
ICM cytoplasmatischen Ursprungs sind (OPPENHEIM und MARCUS, 1970). Eine Ähnlichkeit der Stoffwechsel von Azotobacter spp. und G. oxydans wird in der Arbeit von WHITE und CLAUS (1982) festgestellt. Somit können die ICM von G. oxydans zumindest zeitweise als eine Erweiterung der Cytoplasmamembran angesehen werden, die zum einen die Membran-Oberfläche und zum anderen den periplasmatischen Raum vergrößern.

In Zellen von G. oxydans wurden zunächst Feinstrukturen unter dem Licht- und Elektonenmikroskop beobachtet, die sich an den Zellpolen aus der frühen stat. Wachstumsphase befanden (BATZING und CLAUS, 1973). Es wurden Hinweise gefunden, dass diese ICM-Vesikel mit der Zellhülle in Kontakt stehen. Zeitgleich mit den in der stat. Wachstumsphase auftretenden ICM-Vesikeln oxidieren Zellen fast doppelt so viel Glycerol, verglichen mit Zellen aus der exp. Wachstumsphase. Darüber hinaus konnten große Mengen an Ribosomen an den Zellpolen lokalisiert werden (CLAUS et al., 1975). Die gleichen Beobachtungen wurden später auch bei Wachstum mit Sorbitol als Substrat gemacht. Außerdem oxidieren Zellen aus der frühen stat. Wachstumsphase in gesteigertem Maße auch andere Substrate als die zur Anzucht benutzten, darunter Mannitol, Glycerol und Glucose (WHITE und CLAUS, 1982). Gemessen wurde allerdings in allen Fällen die Respirationsrate, der Sauerstoffverbrauch, der in G. oxydans generell sehr hoch ist und nur noch von Azotobacter spp. übertroffen wird. Die Menge an Lipiden steigt in Zellen aus der stat. im Vergleich zur exp. Wachstumsphase um ca. $60 \%$ an, wobei die Tatsache berücksichtigt wurde, dass Zellen aus der stat. Wachstumsphase ein größeres Volumen haben (HEEFNER und CLAUS, 1976). Diese Zunahme wurde der Entwicklung von ICM zugeschrieben. Des Weiteren wurde herausgefunden, dass sich in der Zusammensetzung der Membranlipide der Anteil von Phosphatidylethanolamin zu Phosphatidylcholin verschiebt. Dies scheint jedoch eher ein Reifeprozess der Membranen während des Übergangs zur stat. Wachstumsphase zu sein. Gleichzeitig ändert sich jedoch der Anteil der veresterten Fettsäuren von der unverzweigten Hexadecansäure zur Anteiso-Palmitinsäure, die als eine an der drittletzten Position verzweigte Fettsäure einen niedrigeren Schmelzpunkt aufweist und somit die Fluidität der Membranen steigert. Dies könnte mit der Entwicklung von ICM zusammenhängen (HEEFNER und CLAUS, 1978).

Der Stoffwechsel von G. oxydans und die kurze Elektronentransportkette über eine membranständige oder im Periplasma lokalisierte Dehydrogenase, den Ubichinon-Pool 
auf eine Quinol-Oxidase wurde in Kap. 1.2 bereits vorgestellt. Die Abb. 1.1. zeigt schematisch die Verwertung von Mannitol, wie sie von DEPPENMEIER und EHRENREICH (2009) bzw. PETERS et al. (2013) vorgeschlagen wird. Mannitol wird zunächst von der membrangebundenen PQQ-abhängigen Polyol-Dehydrogenase GOX0854/0855 zu Fructose oxidiert (1), die über eine Permease in die Zelle aufgenommen wird (2). Dort wird die Fructose über den Pentose-Phosphatweg in den Stoffwechsel der Zelle eingeschleust, bis zum Acetat katabolisiert und in das umgebende Medium abgegeben (PETERS et al., 2013).

Die bei der Oxidation erhaltenen Elektronen gelangen via PQQ in den Ubichinon-Pool und von dort auf eine Quinol-Oxidase (3). In diesem Fall handelt es sich um eine Quinol-Oxidase des bo3-Typs (GOX1911GOX1914), die bei der Reduktion von Sauerstoff zu Wasser einen Protonengradienten generiert, der mittels der $\mathrm{F}_{\mathrm{o}} \mathrm{F}_{1}$-ATPase

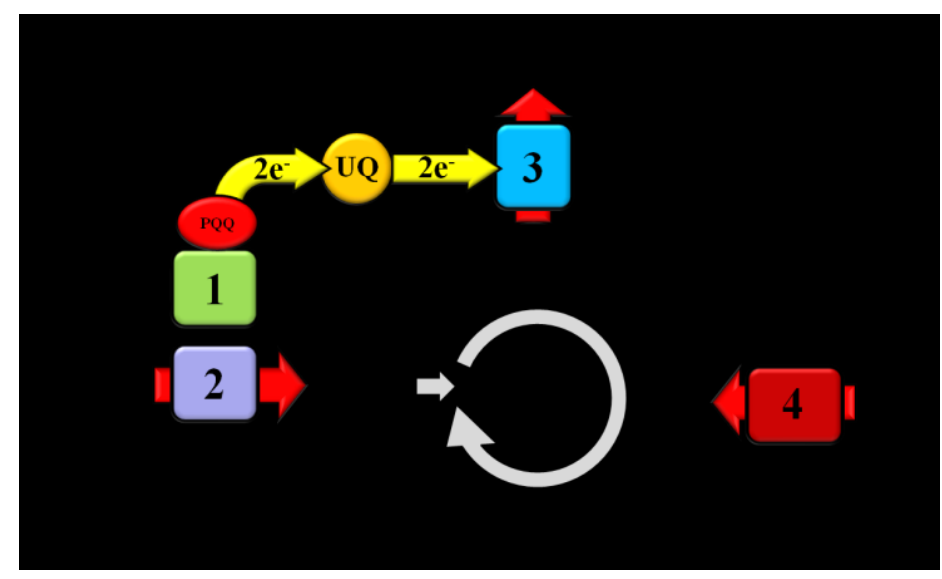

Abb. 1.1.: Mannitol-Verwertung in G. oxydans

ÄM: Äussere Membran, PP: Periplasma, CM: CytoplasmaMembran, UQ: Ubichinon-Pool.

(1): Polyol-Dehydrogenase, (2): Fructose-Permease, (3): QuinolOxidase bo3-Typ (4): $\mathrm{F}_{0} \mathrm{~F}_{1}$-ATPase. Erläuterung im Text.

zur ATP-Bildung genutzt wird (4). Das Substratspektrum der Polyol-Dehydrogenase ist breit, es werden neben D-Mannitol noch Glycerol und weitere Polyole, sekundäre und cyclische Alkohole, Gluconat und einige Zucker umgesetzt (PETERS et al., 2013). Glycerol wird z. B. zu Dihydroxyaceton oxidiert, Substrat und Produkt können jeweils über ein Facilitator-Protein, resp. ABC-Transporter in die Zelle aufgenommen und in den Stoffwechsel eingeschleust werden (PRUST et al., 2005; DEPPENMEIER und EHRENREICH, 2009). Die Verwertung von Glucose wurde bereits in Kap. 1.2 behandelt, die Umsetzung von Glucose zu Gluconat im Periplasma erfolgt durch die membranständige, PQQ-abhängige Glucosedehydrogenase GOX0265. Ethanol wird entsprechend $\mathrm{zu}$ den hier vorgestellten unvollständigen Oxidationen durch die membranständige, PQQ-abhängige Dehydrogenase GOX1067/GOX1068 zu Acetaldehyd oxidiert. Acetaldehyd wird in analoger Weise zu Acetat umgesetzt. Die Oxidation von Ethanol zu Acetat kann aber auch intrazellulär stattfinden (PETERS et 
al., 2013; DEPPENMEIER und EHRENREICH, 2009). Die vollständige Sequenzierung des Genoms von G. oxydans ATCC 621H (PRUST et al., 2005) enthüllte, neben den acht bisher bekannten, zwei weitere membranständige, PQQ-abhängige Dehydrogenasen, mit bisher unbekannter Funktion (PETERS et al., 2013). Darunter befindet sich GOX1441, die PQQ-abhängige Dehydrogenase 3, welche mit 87,8 kDa relativ klein ist und im Gegensatz zu vergleichbaren Enzymen in G. oxydans nur aus einer Untereinheit besteht. GOX1441 bildet neben den bereits erwähnten membranständigen, PQQ-abhängigen Dehydrogenasen GOX1067/GOX1068, GOX0265, und GOX0854/0855 sowie der Quinol-Oxidase des bo3-Typs GOX1911GOX1914 den Schwerpunkt der hier vorliegenden Arbeit.

\subsection{Ziele der Arbeit}

Die Arbeit von WHITE und CLAUS von 1982 war bis zur Vorlage dieser Dissertation die letzte Studie über intracytoplasmatische Membranen (ICM) in Gluconobacter oxydans. Die Biotechnologie hat in den letzten Jahrzehnten an Bedeutung gewonnen und G. oxydans wird Dank seines einmaligen Stoffwechsels im zunehmenden Maße für die Herstellung wirtschaftlich relevanter Produkte genutzt (De Muynck et al., 2007).

Ziel dieser Arbeit war es, das biotechnologische Potential von G. oxydans durch Grundlagenforschung weiter zu verbessern. Das Vorkommen von ICM in G. oxydans im Allgemeinen, ihre Entwicklung und die Möglichkeit, durch eine gesteigerte Präsenz von membranständigen Dehydrogenasen in den ICM den Umsatz von Substraten zu nützlichen Produkten zu optimieren, stehen dabei im Focus. Mittels biochemischer Methoden und Transmissions-Elektronenmikroskopie (TEM) sind die Beobachtungen von CLAUS et al. (1975) zu untersuchen, dass zeitgleich mit dem Auftreten von ICM in der stationären Wachstumsphase eine erhöhte Respirationsrate und eine gesteigerte Produktbildung festzustellen ist. Neben der Messung spezifischer Aktivitäten membranständiger, PQQ-abhängiger Dehydrogenasen sind polyklonale Antikörper herzustellen, mit deren Hilfe Enzyme in Zellen von G. oxydans Immunogold-markiert werden können. Die Fusion derartiger Enzyme mit einem geeigneten fluoreszierenden Protein könnte ein weiteres Werkzeug sein, um das Wissen über membranständige Dehydrogenasen, Oxidasen oder ICM zu erweitern (VAN ROESSEL und BRAND, 2002). Darüber hinaus soll mit Hilfe der genannten Methoden nach Möglichkeiten gesucht werden, um den Substratumsatz durch G. oxydans zu verbessern. 


\section{Material und Methoden}

Materialien: Chemikalien, Hilfsmittel, Geräte, Apparaturen, kommerziell erhältliche Systeme sowie Proteine, Antikörper, Oligonukleotide und Enzyme sind im Anhang (s. Kap. 7) aufgeführt.

\subsection{Verwendete Bakterienstämme und Plasmide}

Die Stämme und deren Referenzen oder Quellen sind der Tab. 2.1. zu entnehmen. Die konstruierten oder durch Kooperationspartner erhaltenen Plasmide sind in der Tab. 2.2. aufgeführt. Die Deletionsmutanten wurden von Kooperationspartnern nach PETERS et al. (2012) hergestellt.

Tab. 2.1.: Verwendete Bakterienstämme

\begin{tabular}{|c|c|}
\hline Stamm & Referenz/Quelle \\
\hline \multicolumn{2}{|l|}{ Gluconobacter oxydans } \\
\hline ATCC 621H (DSM 2343) & Gillis and de Ley, 1980 \\
\hline G. oxydans $\Delta$ upp $\Delta$ gox0854/0855 & A. Ehrenreich, TU München \\
\hline \multicolumn{2}{|l|}{ G. oxydans $\Delta u p p$} \\
\hline$\Delta$ gox0854/0855 · pQIDH- gox0854/0855 & A. Ehrenreich, TU München \\
\hline \multicolumn{2}{|l|}{ G. oxydans $\Delta$ upp } \\
\hline$\Delta$ gox0854/0855 $\cdot \mathrm{pADH}-$ gox0854/0855 & A. Ehrenreich, TU München \\
\hline \multicolumn{2}{|l|}{ G. oxydans $\quad$ uppp $\quad$ goxox $084 / 0855$} \\
\hline pBBR1p264-gox0854-Strep/gox0855 & U. Deppenmeier, Univ. Bonn \\
\hline G. oxydans $\Delta$ upp $\Delta$ gox1911-1914 & S. Bringer-Meyer, FZ Jülich \\
\hline \multirow[t]{2}{*}{ Escherichia coli DH5a (DSM 6897) } & Hanahan, 1983 \\
\hline & Yannisch-Perron et al, 1985 \\
\hline G. oxydans $\mathrm{p} 264-\mathrm{eGPp} 1$ & Diese Arbeit \\
\hline G. oxydans $\mathrm{p} 384-\mathrm{eGPp} 1$ & Diese Arbeit \\
\hline G. oxydans $\mathrm{p} 452-\mathrm{eGPp} 1$ & Diese Arbeit \\
\hline G. oxydans p264-GOX1441-eGPp1 & Diese Arbeit \\
\hline G. oxydans p384-GOX1441-eGPp1 & Diese Arbeit \\
\hline G. oxydans p452-GOX1441-eGPp1 & Diese Arbeit \\
\hline
\end{tabular}


Gluconobacter oxydans $621 \mathrm{H}$ und die daraus hervorgegangenen Stämme besitzen eine natürliche Resistenz gegenüber dem Antibiotikum Cefoxitin.

Tab. 2.2.: Verwendete Plasmide

\begin{tabular}{ll}
\hline Plasmid & Referenz/Quelle \\
\hline pBBR1p264 & Kallnik et al., 2010 \\
pBBR1p384 & U. Deppenmeier, Universität Bonn \\
pBBR1p452 & Kallnik et al., 2010 \\
pBBR1p264-eGPp1 & Diese Arbeit \\
pBBR1p384-eGPp1 & Diese Arbeit \\
pBBR1p452-eGPp1 & Diese Arbeit \\
pBBR1p264-GOX1441-eGPp1 & Diese Arbeit \\
pBBR1p384-GOX1441-eGPp1 & Diese Arbeit \\
pBBR1p452-GOX1441-eGPp1 & Diese Arbeit \\
\hline
\end{tabular}

Alle in Tab. 2.2. aufgelisteten Plasmide sind Derivate des broad-host-range cloning vector pBBR1MCS (KOVACH et al., 1994) und verleihen den Stämmen GentamicinResistenz.

\subsection{Medien}

Alle Puffer, Lösungen und Medien wurden mit deionisiertem Wasser angesetzt und 20 min im Autoklaven bei $121^{\circ} \mathrm{C}$ und 2 bar autoklaviert. Andere Lösungsmittel sind ggf. angegeben. Thermolabile Substanzen wurden separat gelöst, sterilfiltriert und nach dem Autoklavieren hinzugegeben. Alle Angaben in Gewichtsprozent (w/v) beziehen sich auf Wasser. Zur Herstellung fester Medien (Agar-Platten) wurden den entsprechenden Flüssigmedien 1,6\% (w/v) Agar vor dem Autoklavieren zugesetzt.

\subsubsection{Standard Mannitol-Medium}

Hefeextrakt

Mannitol 


\subsubsection{Standard Glycerol-Medium}

Hefeextrakt

$6,0 \mathrm{~g}$

Glycerol (50\%ige Lösung)

$15,6 \mathrm{ml}$

$\mathrm{H}_{2} \mathrm{O}$ ad $1000 \mathrm{ml}$

\subsubsection{Komplex-Medium}

Hefeextrakt $5,0 \mathrm{~g}$

Pepton

$3,0 \mathrm{~g}$

$\mathrm{H}_{2} \mathrm{O}$ ad $1000 \mathrm{ml}$

Der pH-Wert wurde mit $\mathrm{HCl}$ auf 6,0 eingestellt. $50 \mathrm{mM}$ Mannitol wurden vor dem Autoklavieren, $50 \mathrm{mM}$ Fruktose, Glucose, Sorbitol oder Glycerol nach dem Autoklavieren hinzugefügt.

\subsubsection{Luria-Bertani (LB)-Medium}

Hefeextrakt

$5,0 \mathrm{~g}$

Trypton $10,0 \mathrm{~g}$

$\mathrm{NaCl}$ $10,0 \mathrm{~g}$

$\mathrm{H}_{2} \mathrm{O}$ ad $1000 \mathrm{ml}$

\subsubsection{SOB-Medium}

Hefeextrakt $5,0 \mathrm{~g}$

Trypton $20,0 \mathrm{~g}$

$\mathrm{NaCl}$ $0,58 \mathrm{~g}$

$\mathrm{KCl}$ $0,19 \mathrm{~g}$

$\mathrm{MgCl}_{2} \cdot 6 \mathrm{H}_{2} \mathrm{O}$ $2,03 \mathrm{~g}$

$\mathrm{MgSO}_{4} \cdot 7 \mathrm{H}_{2} \mathrm{O}$

$2,46 \mathrm{~g}$

$\mathrm{H}_{2} \mathrm{O}$ ad $1000 \mathrm{ml}$ 
Zur Herstellung chemisch kompetenter Zellen wurde E. coli in SOB-Medium angezogen (2.4.8.1). Die Magnesiumsalze wurden den übrigen Medienbestandteilen nach dem Autoklavieren getrennt zugegeben.

\subsubsection{Elektroporations-Medium}

Hefeextrakt $15,0 \mathrm{~g}$

Mannitol $80,0 \mathrm{~g}$

Glycerol (87\%) $0,7 \mathrm{ml}$

$\mathrm{CaCl}_{2} \cdot 2 \mathrm{H}_{2} \mathrm{O}$ $2,0 \mathrm{~g}$

$\mathrm{MgSO}_{4} \cdot 7 \mathrm{H}_{2} \mathrm{O}$

$2,46 \mathrm{~g}$

$\mathrm{H}_{2} \mathrm{O}$ ad $1000 \mathrm{ml}$

\subsubsection{Medienzusätze}

Die Stammlösungs- und Arbeitskonzentrationen von den in dieser Arbeit verwendeten Antibiotika und anderen Medienzusätzen sind in Tabelle 2.3. aufgeführt.

Tabelle 2.3.: Medienzusätze

\begin{tabular}{lcc}
\hline Medienzusatz & Stammlösung & Endkonzentration \\
\hline Cefoxitin & $50 \mathrm{mg} / \mathrm{ml} \mathrm{in} \mathrm{H}_{2} \mathrm{O}$ & $50 \mu \mathrm{g} / \mathrm{ml}$ \\
Kanamycin & $50 \mathrm{mg} / \mathrm{ml} \mathrm{in} \mathrm{H}_{2} \mathrm{O}$ & $50 \mu \mathrm{g} / \mathrm{ml}$ \\
Thymidin & $10 \mathrm{mM}$ in $\mathrm{H}_{2} \mathrm{O}$ & $10 \mu \mathrm{M}$ \\
\hline
\end{tabular}

\subsection{Anzucht von Bakterien}

Flüssigkulturen von Gluconobacter-Stämmen wurden i. d. R. bei $30{ }^{\circ} \mathrm{C}$ in Standard Mannitol-Medium, flüssige E. coli-Kulturen bei $37^{\circ} \mathrm{C}$ in LB-Medium mit den entsprechenden Antibiotika (Tab. 2.3.) durch Animpfen aus Kryokulturen (2.3.1) angelegt. Die Anzucht erfolgte in Erlenmeyer-Kolben ohne Schikane auf einem Rundschüttler. Wenn keine Abweichungen angegeben sind, betrug die Rotationsgeschwindigkeit 200 upm und das Volumen der Kultur entsprach $10 \%$ des Volumens des Erlenmeyer-Kolbens. Für Versuche wurde aus diesen Vorkulturen Hauptkulturen mit einer optischen Dichte (OD) von 0,1 bei $600 \mathrm{~nm}$ eingestellt. Gluconobacter-Stämmen, deren Uracil Phosphoribosyltransferase deletiert worden ist 
( $\Delta u p p$, Tab. 2.1.), wurde Thymidin in der angegebenen Konzentration zugegeben (Tab. 2.3.).

\subsubsection{Stammhaltung}

Zur Konservierung von Stämmen wurde ein Selektivmedium mit einer einzelnen Kolonie beimpft und für 24 Stunden unter den unter Kapitel 2.3 beschriebenen Bedingungen angezogen. Die jeweiligen Kryokulturen wurden in 1,5 ml MikroSchraubröhren mit Glycerin oder DMSO nach folgendem Schema angelegt:

DMSO $\quad(99,9 \%) \quad 80 \mu 1 \quad 920 \mu 1$ Zellkultur

Glycerin $(50,0 \%) \quad 200 \mu 1 \quad 800 \mu 1$ Zellkultur

Die erhaltenen Suspensionen wurden durch sanftes Vortexen kurz gemischt, in flüssigem Stickstoff eingefroren und bei $-80^{\circ} \mathrm{C}$ gelagert.

\subsubsection{Die Aufnahme von Wachstumskurven}

Vorkulturen für Wachstumskurven wurden wie unter Kapitel 2.3 beschrieben angezogen. Daraus wurden jeweils $100 \mathrm{ml}$ Kultur mit einer $\mathrm{OD}_{600}$ von 0,1 hergestellt, aus der jeweils Kulturen von $10 \mathrm{ml}$ Volumen in Erlenmeyer-Kolben mit $100 \mathrm{ml}$ Volumen aliquotiert wurden. Die Wachstumskurven wurden über $48 \mathrm{~h}$ aufgenommen, wobei innerhalb der ersten $12 \mathrm{~h}$ alle $2 \mathrm{~h}$ und darauffolgend nach jeweils $12 \mathrm{~h}$ ein Erlenmeyer-Kolben entnommen und mit einem Photometer die $\mathrm{OD}_{600}$ der Kultur gemessen wurde. Das Wachstum der jeweiligen Stämme wurde in zwei voneinander unabhängigen Versuchen untersucht. Der Mittelwert der erhaltenen Daten wurde in logarithmischer Auftragung zur Basis 10 gegen die Zeit aufgetragen. 


\subsubsection{Ermittlung der Wachstumsraten und Verdopplungszeiten}

Aus den linear verlaufenden Abschnitten der Wachstumskurven lassen sich die entsprechenden max. Wachstumsraten $\mu$ und hieraus die Verdopplungszeiten $t_{d}$ mit Hilfe der Formeln (1) und (2) berechnen.

\subsection{Genetische Methoden}

In dieser Arbeit wurde DNA präpariert und aufgereinigt, DNA-Abschnitte durch die Polymerasekettenreaktion (Polymerase Chain Reaction, PCR) amplifiziert und Plasmide konstruiert. Die Ergebnisse und Zwischenschritte wurden überprüft und dokumentiert, wobei die molekularbiologischen Routinetechniken nach SAMMBROCK et al. (1989) durchgeführt wurden. Die Fusion von Genen mittels Overlap extension PCR erfolgte nach WURCH et al. (1998). Am Ende dieses Kapitels sind alle Lösungen aufgelistet, die aus mehr als einer Komponente zusammengesetzt sind.

\subsubsection{Strategie zur Konstruktion von Plasmiden}

Die im Rahmen dieser Arbeit konstruierten oder durch Kooperationspartner erhaltenen Plasmide sind in Tab. 2.2. aufgeführt. Alle Plasmide sind letztendlich Derivate des broad-host-range Klonierungs-Vektors pBBR1MCS (KOVACH et al., 1994). Plasmide wurden i.d.R. in E. coli DH5 $\alpha$ transformiert (2.4.8) und in dem Organismus zur Lagerung bei $-80^{\circ} \mathrm{C}$ eingefroren (2.3.1.). Um mit den Plasmiden arbeiten zu können, wurden die Stämme angezogen und die Plasmide präpariert.

Alle zur Konstruktion von Plasmiden benutzten Primer (Tabelle 7.X.Y) besaßen neben den erforderlichen Restriktionsschnittstellen einen Überhang von $3 \times$ Desoxythymidin. Damit befanden sich die entsprechenden Schnittstellen weiter innerhalb des DNAMoleküls, was den Restriktionsendonukleasen das Binden an der DNA erleichterte. Schnittstellen wurden ggf. so gewählt, dass die DNA-Fragmente hinter die Promotoren auf den Plasmiden kloniert werden konnten. Die Wahl zweier unterschiedlicher Restriktionsschnittstellen ermöglichte die zielgerichtete Ligation der Fragmente in die Plasmide (2.4.7.3). Mittels der Primer wurden DNA-Fragmente durch PCR (2.4.4) 
amplifiziert, als Matrizen-DNA dienten Plasmide oder chromosomale DNA (2.4.2). Der Erfolg wurde mit Hilfe der Agarose-Gelelektrophorese überprüft (2.4.5) und bei Erfolg das PCR-Produkt aufgereinigt (2.4.3). Die amplifizierten Fragmente wurden entweder in die gewünschten Plasmide kloniert oder zunächst durch Overlap Extension PCR fusioniert (2.4.4.2). Ligationsansätze wurden komplett in E. coli DH5 $\alpha$ transformiert und positive Transformanten mittels Colony-PCR ermittelt (2.4.4.1). Die DNA-Sequenz des neu konstruierten Bereichs der Plasmide wurde durch Sequenzierung überprüft, diese erfolgte nach dem Prinzip der Kettenabbruchmethode von Sanger (SANGER, 1977) mit fluoreszenzmarkierten Didesoxynukleotiden. Sequenzierungen wurden durch das Laboratorium für Genomanalyse der Georg-August-Universität Göttingen durchgeführt. Erfolgreich konstruierte und überprüfte Plasmide wurden i.d.R. via Elektroporation in G. oxydans $621 \mathrm{H}$ transformiert.

\subsubsection{Präparation chromosomaler DNA}

Eine innerhalb von $8 \mathrm{~h}$ von $\mathrm{OD}_{600}$,, 1 auf 1,0 in Standard-Medium angewachsene 50 ml-Kultur von $G$. oxydans $621 \mathrm{H}$ wurde mit $8000 \mathrm{upm}(\stackrel{\wedge}{=} 8873 \times \mathrm{g})$ für $10 \mathrm{~min}$ bei $4{ }^{\circ} \mathrm{C}$ abzentrifugiert. Das Pellet wurde in $4 \mathrm{ml}$ frischem Medium resuspendiert und es wurden $200 \mu \mathrm{l}$ Lysozym $(10 \mathrm{mg} / \mathrm{ml})$ und $200 \mu \mathrm{l}$ EDTA $(0,25 \mathrm{M})$ hinzugegeben. Nach mehrmaligem Umschwenken wurde die Suspension $30 \mathrm{~min}$ bei $37^{\circ} \mathrm{C}$ inkubiert. Anschließend wurden $200 \mu \mathrm{l}$ Proteinase K (2,5 mg/ml) und $200 \mu \mathrm{l} \operatorname{SDS}(12,5 \%$ (w/v)) hinzugegeben und geschwenkt, bis sich der Ansatz vollständig klärte. Es folgte eine dreißig- bis vierzigminütige Inkubation bei $37^{\circ} \mathrm{C}$. Danach wurden $0,5 \mathrm{ml} \mathrm{NaCl}(5 \mathrm{M})$ und $4 \mathrm{ml}$ Chloroform-Oktanol ( $5 \mathrm{Vol}+1 \mathrm{Vol})$ zugegeben und bis zum Entstehen einer feinen Emulsion geschüttelt. Diese wurde weitere 5 min durch Umschwenken bewegt. Durch eine Zentrifugation für $30 \mathrm{~min}$ mit $8000 \mathrm{upm}$ bei $4{ }^{\circ} \mathrm{C}$ wurden die Phasen getrennt. Sofern die obere wässrige Phase, welche die gelöste DNA enthielt, klar erschien, wurde diese mit einer Pipette mit abgeschnittener Spitze abgehoben. War die obere Phase noch getrübt, so wurde dieser letzte Schritt wiederholt. Dann wurde die DNA-Lösung mit 2 Volumen gekühltem Ethanol überschichtet ( $95 \%$, vergällt) und die DNA für mindestens $30 \mathrm{~min}$ bei $-20^{\circ} \mathrm{C}$ gefällt. Diese wurde dann $30 \mathrm{~min}$ bei $8000 \mathrm{upm}$ und $4{ }^{\circ} \mathrm{C}$ zentrifugiert. Das Pellet wurde an der Luft getrocknet, bevor es mit $70 \%$ igem vergälltem Ethanol gewaschen und in $50 \mu \mathrm{H}_{2} \mathrm{O}_{\text {Millipore }}$ oder Tris-HCL Puffer ( $\mathrm{pH} 8,5$ ) resuspendiert wurde. 


\subsubsection{Präparation von Plasmiden und linearisierter DNA}

Das ,peqGOLD Plasmid Miniprep Kit I“ von peqlab ermöglicht die Aufreinigung von bis zu $25 \mu \mathrm{g}$ hochreiner Plasmid-DNA, für deren Isolierung $10 \mathrm{ml}$ einer über Nacht gewachsenen Kultur verwendet wurden. Hierbei wurden die Zellen zunächst durch alkalische Lyse aufgeschlossen, die Plasmid-DNA selektiv an Säulenmaterial gebunden, gewaschen und anschließend mit $\mathrm{H}_{2} \mathrm{O}_{\text {Millipore }}$ oder Tris-HCL Puffer $(\mathrm{pH} 8,5)$ eluiert.

Mit dem ,peqGOLD Cycle-Pure Kit“ von peqlab wurden PCR-Produkte, verdaute oder fusionierte DNA-Fragmente aufgereinigt. Hierbei wurde ebenfalls die DNA an Säulenmaterial gebunden, die DNA gereinigt anschließend mit $\mathrm{H}_{2} \mathrm{O}_{\text {Millipore oder Tris- }}$ HCL Puffer ( $\mathrm{pH} 8,5)$ eluiert. Wenn innerhalb eines Gemischs verschieden großer DNAFragmente eine bestimmte Bande isoliert werden musste, so konnte diese auf einem UV-Leuchttisch bei $\lambda=366 \mathrm{~nm}$ mit einem Skalpell aus einem präparativen Agarosegel ausgeschnitten werden. Die Aufreinigung der DNA aus den Agarose-Gelstücken erfolgte mit dem ,peqGOLD Gel Extraktion Kit“ von peqlab, hier wird die DNA aus dem Gel gelöst, ebenfalls an Säulenmaterial gebunden, gewaschen und anschließend mit

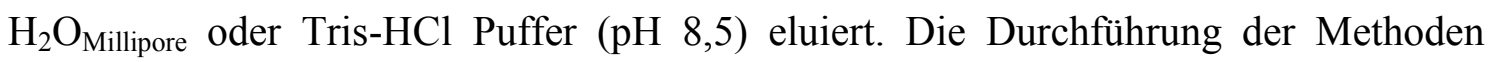
erfolgte nach dem vom Hersteller gelieferten Isolierungsprotokoll.

\subsubsection{Polymerasekettenreaktion (PCR)}

Die PCR ermöglicht spezifische DNA-Fragmente aus einem komplexen DNA-Gemisch enzymatisch zu amplifizieren (MULLIS et al., 1987). Doppelsträngige DNA wird durch Erhitzen auf $94-96{ }^{\circ} \mathrm{C}$ in einzelsträngige DNA überführt (Denaturierung). Durch Absenken der Temperatur können sich zwei Oligonukleotid-Primer an komplementäre Abschnitte der Matrizen-DNA anlagern. Die Oligonukleotid-Primer werden so ausgewählt, dass sie die zu amplifizierende Region flankieren. Im dritten Schritt der PCR werden die beiden Primer mit Hilfe einer thermostabilen Polymerase bei ihrem Temperaturoptimum komplementär zur ursprünglichen doppelsträngigen DNA verlängert (Elongation). Zur Amplifikation wird eine bestimmte Anzahl an Zyklen in einem Thermocycler durchgeführt, wodurch die von den Primern flankierte Region exponentiell akkumuliert wird. Die Anlagerungs-Temperatur wird dabei so gewählt, dass sie ca. $5{ }^{\circ} \mathrm{C}$ unter der Schmelztemperatur $\mathrm{T}_{\mathrm{S}}$ der verwendeten Primer liegt. Hierfür gilt die Näherung: $\mathrm{T}_{\mathrm{S}}\left[{ }^{\circ} \mathrm{C}\right]=(2 \times(\mathrm{A}+\mathrm{T})+4 \mathrm{x}(\mathrm{C}+\mathrm{G}))$. 
Die Elongationszeit hängt von der Größe des erwarteten Produktes ab; sie beträgt mindestens 1 min pro 1000 Basenpaare im Falle der Taq-Polymerase, während die Phusion-Polymerase im Vergleich mit doppelter Geschwindigkeit synthetisiert. Der Erfolg der Amplifikation wird mittels Gelelektrophorese im Agarosegel überprüft (2.4.5).

\section{Grundschema der angewendeten PCR-Programme}

\begin{tabular}{|c|c|c|}
\hline Reaktion & Temperatur & Dauer \\
\hline Initiale Denaturierung & $95^{\circ} \mathrm{C}$ & $5 \mathrm{~min}$ \\
\hline Denaturierung & $95^{\circ} \mathrm{C}$ & $1 \mathrm{~min}$ \\
\hline Anlagerung & $50-65^{\circ} \mathrm{C}$ & 25 Zyklen \\
\hline Elongation & $72{ }^{\circ} \mathrm{C}$ & Nach Bedarf \\
\hline Abschließende Elongation & $72{ }^{\circ} \mathrm{C}$ & $10 \mathrm{~min}$ \\
\hline Abkühlen und Lagerung & $12^{\circ} \mathrm{C}$ & Nach Bedarf \\
\hline
\end{tabular}

\section{$50 \mu l$ PCR-Ansatz mit der Taq-Polymerase}

$\begin{array}{lll}5 \mu \mathrm{l} & 10 \times \text { Taq-ThermoPol Puffer } & \\ 1 \mu \mathrm{l} & \text { dNTP-Mix } & (10 \mathrm{mM}) \\ 5 \mu \mathrm{l} & \text { Vorwärts-Primer } & (5 \mathrm{pmol} / \mu \mathrm{l}) \\ 5 \mu \mathrm{l} & \text { Rückwärts-Primer } & (5 \mathrm{pmol} / \mu \mathrm{l}) \\ 2 \mu \mathrm{l} & \text { Matrizen-DNA } & (\mathrm{ca} .50 \mathrm{ng} / \mu \mathrm{l}) \\ 0,25 \mu \mathrm{l} & \text { Taq-Polymerase } & (5 \mathrm{U} / \mu \mathrm{l}) \\ 31,75 \mu \mathrm{l} & \mathrm{H}_{2} \mathrm{O}_{\text {Millipore }} & \end{array}$




\subsubsection{Colony-PCR}

Die Colony-PCR diente zur Überprüfung rekombinanter E. coli oder G. oxydans Klone. Dazu wurde eine möglichst geringe Menge Zellmaterial gut gewachsener Kolonien der $\mathrm{zu}$ überprüfenden Klone mit einem sterilen Zahnstocher von der Agarplatte abgenommen und in ein PCR-Gefäß, gefüllt mit $25 \mu$ l Master-Mix, überführt. Nach erfolgter Amplifikation wurde der Erfolg der Colony-PCR durch Gelelektrophorese im Agarosegel überprüft (2.4.5).

\subsubsection{Overlap Extension PCR}

Die translationale Fusion von Proteinen wurde durch Overlap Extension PCR (OEPCR) nach WURCH et al. (1998) durchgeführt. Dabei ist es möglich, ohne die Verwendung von Restriktionsenzymen ein chimärisches Gen $\mathrm{zu}$ kreieren, das nur aus den gewünschten Ausgangsgenen besteht, die direkt verknüpft sind. Die OEPCR läuft in drei Schritten ab: das Amplifizieren der Fragmente, deren Fusion und die Amplifikation des Fusionsprodukts. Zwischen den einzelnen Schritten wurden die PCR-Produkte aufgereinigt (2.4.3), einer Agarosegelelektrophorese unterzogen (2.4.5) und bei Bedarf mittels Gelextraktion (2.4.3) isoliert.

\section{Amplifizieren der Fragmente}

In zwei getrennten Reaktionen werden das Fragment 1, welches letztendlich für die Nterminale Hälfte des Fusionsproteins codiert, und das Fragment 2 für die anschließende Fusion amplifiziert (Abb. 2.4.1.). Der Rückwärts-Primer des DNA-Fragments 1 ( $\mathrm{A}_{\text {rev }}$ ) und der Forward-Primer des Fragments $2\left(\mathrm{~B}_{\mathrm{fwd}}\right)$ sind in ihrem jeweiligen 5'-Bereich komplementär zueinander. Diese Komplementarität ist die Grundlage der Fusion der beiden Fragmente im zweiten Schritt. Der komplementäre Bereich sollte mindestens 12 Nukleotide umfassen (WURCH et al., 1998), gefolgt von einem mindestens 21 Nukleotide langen Abschnitt komplementär zu der Sequenz, die zu amplifizieren ist. Der überlappende Bereich der Primer wurde im Rahmen dieser Arbeit auf 30 Nukleotide ausgedehnt. 

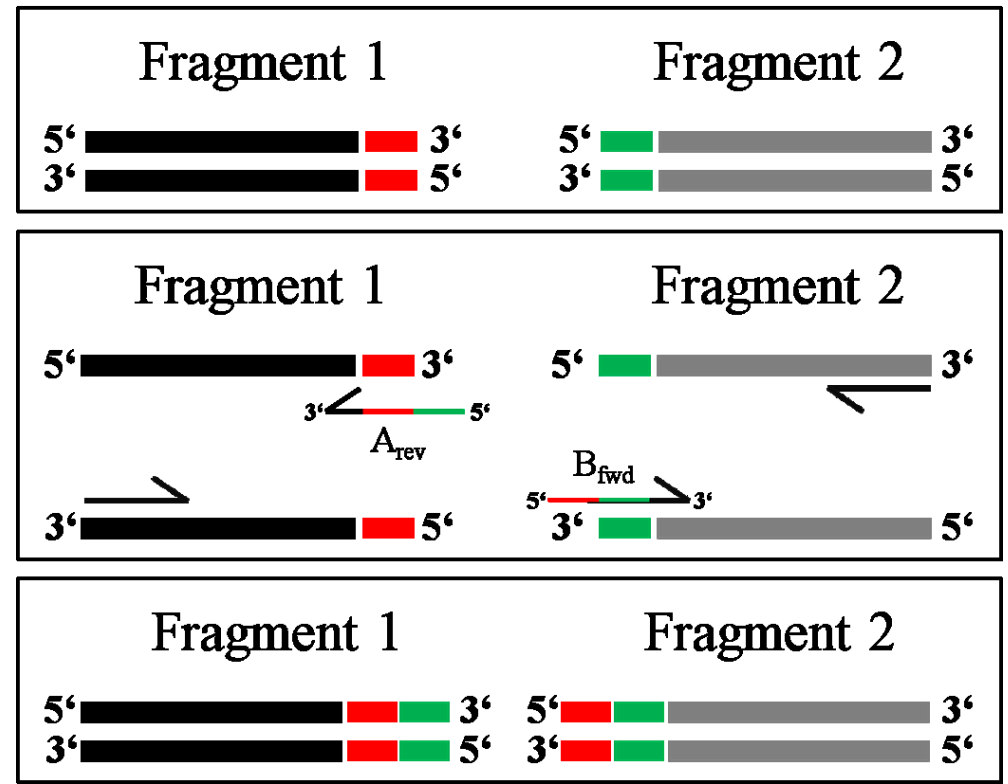

Abb. 2.4.1.: Das Amplifizieren der Fragmente

Die Abbildung zeigt schematisch den Ablauf der ersten PCR-Reaktionen der Overlap Extensin PCR. In zwei getrennten Reaktionen werden den $\mathrm{zu}$ fusionierenden DNAFragmenten komplementäre Überhänge angehängt, die in der folgenden PCR-Reaktion zur Fusion genutzt werden.

\section{Programm Fragment-Amplifikation}

\begin{tabular}{|c|c|c|}
\hline Reaktion & Temperatur & Dauer \\
\hline Initiale Denaturierung & $98^{\circ} \mathrm{C}$ & $60 \mathrm{~s}$ \\
\hline Denaturierung & $98^{\circ} \mathrm{C}$ & $30 \mathrm{~s}$ \\
\hline Anlagerung & $70^{\circ} \mathrm{C}$ & \} 10 Zyklen \\
\hline Elongation & $72{ }^{\circ} \mathrm{C}$ & Nach Bedarf \\
\hline Abschließende Elongation & $72{ }^{\circ} \mathrm{C}$ & $10 \mathrm{~min}$ \\
\hline Abkühlen und Lagerung & $12{ }^{\circ} \mathrm{C}$ & Nach Bedarf \\
\hline
\end{tabular}

Die Denaturierung dieses ersten PCR-Schrittes sollte die $30 \mathrm{~s}$ nicht überschreiten, um eine Degradierung der an den $5^{6}$-Enden überhängenden Nukleotide zu vermeiden (WURCH et al., 1998). 
$50 \mu \mathrm{l}$ PCR-Ansatz mit der Phusion-Polymerase - Fragment-Amplifikation

$10 \mu 1 \quad 5 x$ Phusion-GC-Puffer

$1 \mu \mathrm{l}$ dNTP-Mix $\quad(10 \mathrm{mM})$

$5 \mu \mathrm{l} \quad$ Vorwärts-Primer $\quad(5 \mathrm{pmol} / \mu \mathrm{l})$

$5 \mu \mathrm{l} \quad$ Rückwärts-Primer $\quad(5 \mathrm{pmol} / \mu \mathrm{l})$

$1 \mu \mathrm{l} \quad$ Matrizen-DNA (ca. $100 \mathrm{ng} / \mu \mathrm{l}$ )

$0,5 \mu \mathrm{l} \quad$ Phusion-Polymerase $\quad(2 \mathrm{U} / \mu \mathrm{l})$

$27,5 \mu \mathrm{l} \quad \mathrm{H}_{2} \mathrm{O}_{\text {Millipore }}$

\section{Fusion der Fragmente}

Im Verlauf dieser PCR werden die Fragmente fusioniert. Die komplementären 3'-Überhänge dienen nach der Denaturierung der Fragmente als Primer für die Elongation durch die Polymerase (Abb. 2.4.2.). Die lange Anlagerungszeit verbessert die Basenpaarung der komplementären Bereiche der Fragmente, die hier fusioniert wurden. Nach der Aufreinigung der Fragmente (2.4.3) und dem Bestimmen der DNAKonzentration (2.4.6) konnte anhand der Fragmentlängen die eingesetzten Volumina an Fragmentlösungen ermittelt werden, um beide Fragmente in äquimolarem Verhältnis im PCR-Ansatz zu haben.
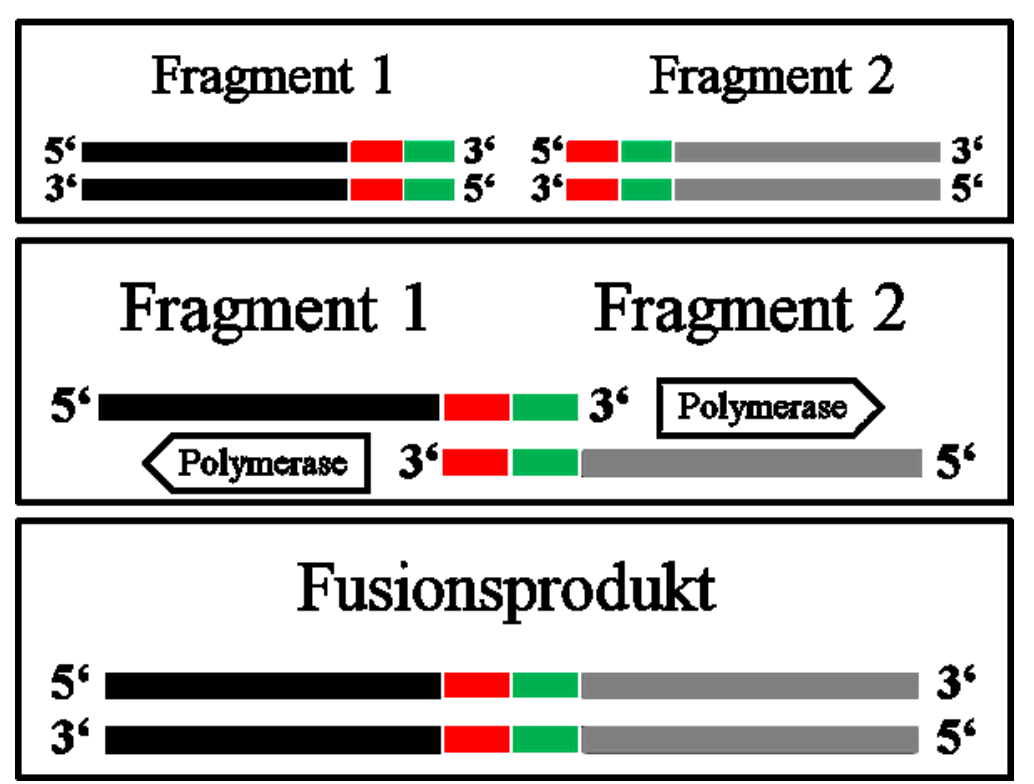

Abb. 2.4.2.: Die Fusion
der Fragmente
Die Abbildung zeigt
schematisch den Ablauf der
PCR-Reaktion, in der die
beiden DNA-Fragmente der
ersten Reaktionen fusioniert
werden. Hierbei dient der
jeweilige 3'-Überhang als
Primer für die DNA-
Polymerase.




\section{Programm Fragment-Fusion}

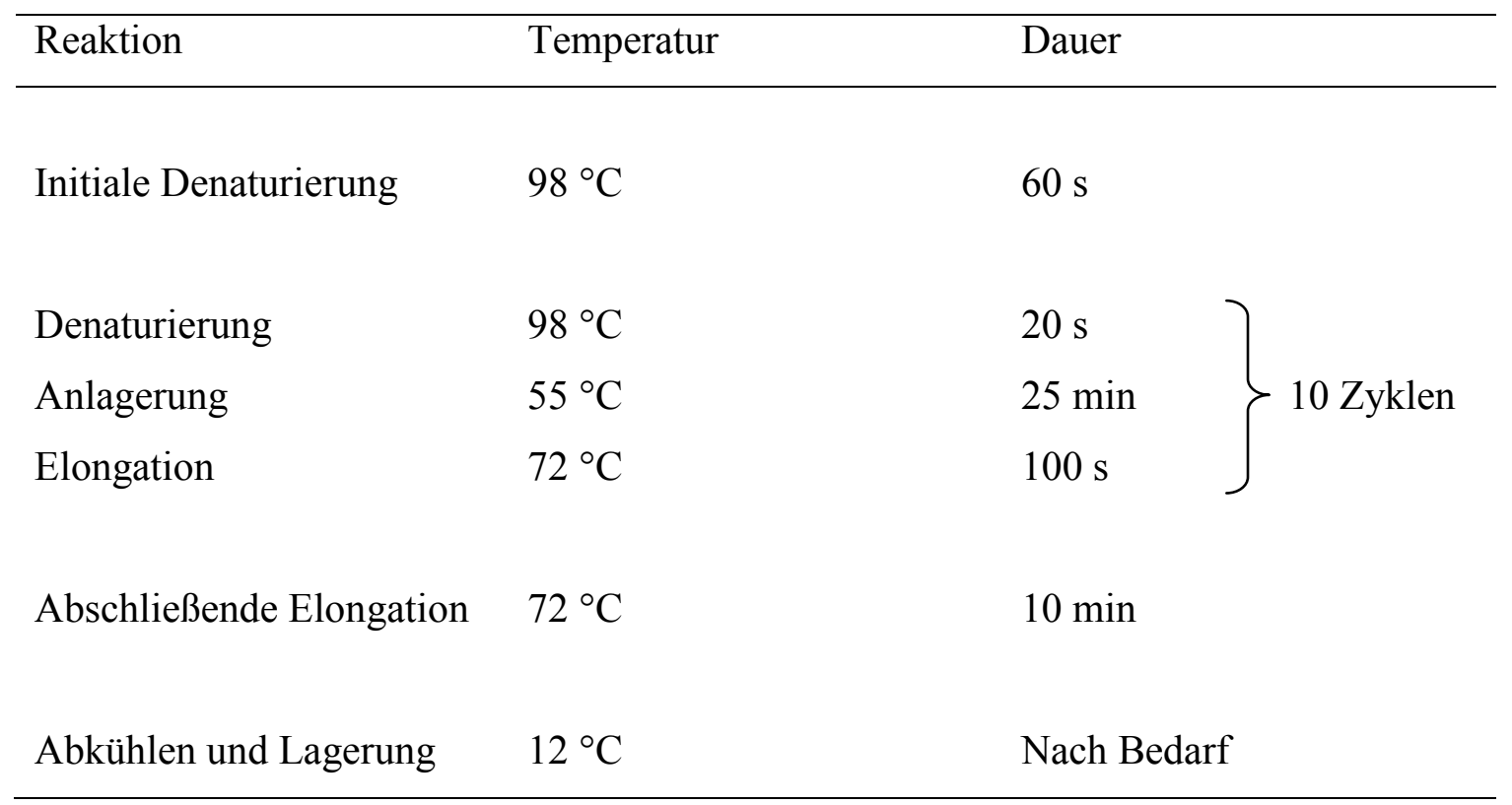

\section{$50 \mu \mathrm{l}$ PCR-Ansatz mit der Phusion-Polymerase - Fragment-Fusion}

$10 \mu 1 \quad 5 x$ Phusion-GC-Puffer

$\begin{array}{cll}2 \mu \mathrm{l} & \text { dNTP-Mix } & (10 \mathrm{mM}) \\ 10 \mu \mathrm{l} & \text { DNA-Fragmente } & (10-100 \mathrm{ng} / \mu \mathrm{l}) \\ 0,5 \mu \mathrm{l} & \text { Phusion-Polymerase } & (2 \mathrm{U} / \mu \mathrm{l})\end{array}$

$27,5 \mu 1 \quad \mathrm{H}_{2} \mathrm{O}_{\text {Millipore }}$

Das nach der Fusion aufgereinigte Produkt wurde mittels Speed-Vac pelletiert und in 28,5 $\mu \mathrm{l} \mathrm{H}_{2} \mathrm{O}_{\text {Millipore }}$ resuspendiert, um vollständig für die erfolgte Amplifikation eingesetzt werden zu können.

\section{Amplifikation des Fusionsprodukts}

Das Fusionsprodukt wurde in einem letzten PCR Schritt mit den außen liegenden Primern amplifiziert ( $\mathrm{A}_{\mathrm{fwd}}$ und $\mathrm{B}_{\mathrm{rev}}, \mathrm{Abb}$. 2.4.3.). Das PCR-Programm wurde für eine höhere Ausbeute an Fusionsprodukt modifiziert, statt 10 sind 25 Zyklen durchgeführt worden. 

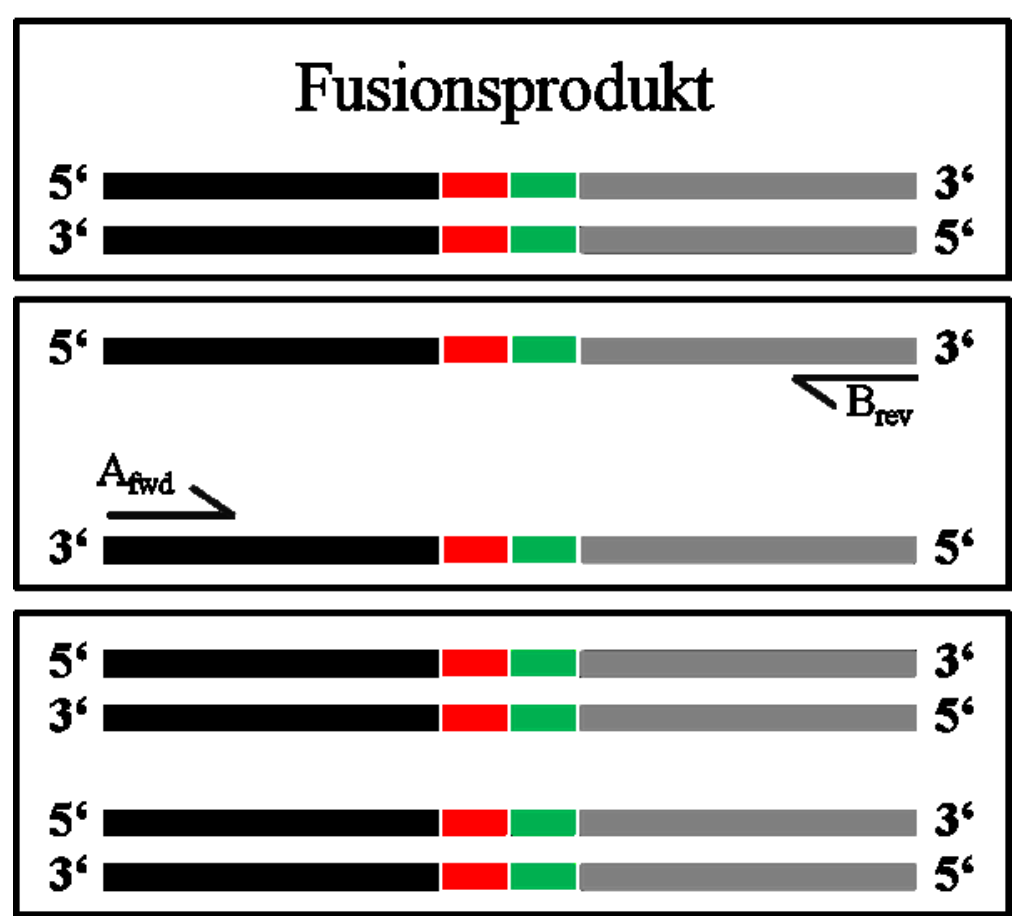

Abb. Amplifikation

2.4.3.: des Fusionsprodukts

Die Abbildung 2.3. zeigt den letzten Schritt der Overlap Extension PCR, der im Prinzip einer normalen PCR entspricht. Mit Hilfe der Primer $\mathrm{A}_{\mathrm{fwd}}$ und $B_{\text {rev }}$, die auch schon in den ersten PCR-Reaktionen zur Amplifikation der Fragmente benutzt worden sind, wird das Fusionsprodukt vervielfältigt.

Programm Amplifikation des Fusionsproduktes

$\left.\begin{array}{lll}\hline \text { Reaktion } & \text { Temperatur } & \text { Dauer } \\ \hline \text { Initiale Denaturierung } & 98^{\circ} \mathrm{C} & 30 \mathrm{~s} \\ & \\ \text { Denaturierung } & 98^{\circ} \mathrm{C} & 20 \mathrm{~s} \\ \text { Anlagerung } & 70^{\circ} \mathrm{C} & 60 \mathrm{~s} \\ \text { Elongation } & 72^{\circ} \mathrm{C} & 160 \mathrm{~s}\end{array}\right\} 25$ Zyklen
Abschließende Elongation
$72{ }^{\circ} \mathrm{C}$
$10 \min$

Abkühlen und Lagerung $\quad 12{ }^{\circ} \mathrm{C} \quad$ Nach Bedarf

$50 \mu$ I PCR-Ansatz mit der Phusion-Polymerase - Amplifikation Fusionsprodukt

$10 \mu 1 \quad 5 x$ Phusion-GC-Puffer

$\begin{array}{cll}1 \mu \mathrm{l} & \text { dNTP-Mix } & (10 \mathrm{mM}) \\ 5 \mu \mathrm{l} & \text { Vorwärts-Primer } & (5 \mathrm{pmol} / \mu \mathrm{l}) \\ 5 \mu \mathrm{l} & \text { Rückwärts-Primer } & (5 \mathrm{pmol} / \mu \mathrm{l}) \\ 28,5 \mu \mathrm{l} & \text { Fusions-Produkt } & (100 \mathrm{ng} / \mu \mathrm{l}) \\ 0,5 \mu \mathrm{l} & \text { Phusion-Polymerase } & (2 \mathrm{U} / \mu \mathrm{l})\end{array}$




\subsubsection{DNA-Gelelektrophorese}

Die Größenbestimmung und präparative Auftrennung von PCR-Produkten erfolgte mittels Gelelektrophorese in Agarosegelen. Die negativ geladenen Nukleinsäuren bewegen sich im elektrischen Feld zur Anode, wobei deren jeweilige Laufgeschwindigkeit umgekehrt proportional zu ihrer Molekularmasse ist. Es erfolgt somit eine Auftrennung der DNA-Fragmente entsprechend ihrer Größe. Die Agarose wurde in $1 \times$ TAE unter kurzem Aufkochen in einer Mikrowelle gelöst, bis eine klare homogene Lösung entstand. Die 1 \%ige Agaroselösung wurde kurz abgekühlt, in eine Gellaufkammer gegossen und ein Taschenkamm eingesetzt. Nach dem Erstarren des Agarosegels wurde es mit TAE-Puffer bedeckt, anschließend wurde der Taschenkamm entfernt.

Die mit DNA-Farbmarker versetzten Proben wurden in die Geltaschen gefüllt. Dieser diente einerseits zur Beschwerung der Proben als auch zur Markierung der Lauffront bei ca. 500 bp. Für die Auftrennung der DNA-Proben im Gel wurde die Spannung bei $90 \mathrm{~V}$ konstant eingestellt, bis die Bromphenolblaubande das untere Drittel des Gels erreicht hatte. Nach Beendigung des Laufes wurde die DNA für $10 \mathrm{~min}$ bei RT in einem Ethidiumbromidbad $(5 \mu \mathrm{g} / \mathrm{ml})$ gefärbt und das Gel anschließend in einem Wasserbad für 10 min bei RT entfärbt. In einer Gel-Dokumentationsanlage wurde die DNA mit UV-Licht $(254 \mathrm{~nm})$ durch das eingelagerte Ethidiumbromid sichtbar gemacht und fotografisch dokumentiert. Zur Abschätzung der Größe von DNA-Fragmenten wurden die im Anhang aufgeführten DNA-Größenstandards mit Nukleinsäuren von 0,5 bis 10 $\mathrm{kb}$, bzw. 0,1 bis $1,5 \mathrm{~kb}$, verwendet.

\subsubsection{Konzentrationsbestimmungen von DNA}

Die Konzentration von DNA-Lösungen wurde anhand der Absorption von DNA bei einer Wellenlänge von $260 \mathrm{~nm}$ mit einem UV/Vis-Spektralphotometer (Nanodrop) bestimmt. Der Nullabgleich wurde mit dem Lösungsmittel vorgenommen in dem die

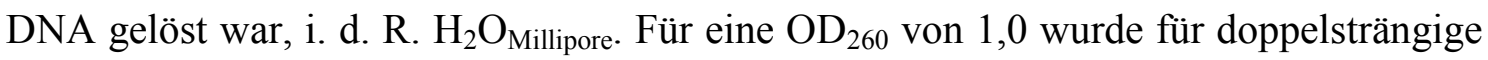
DNA eine Konzentration von $50 \mu \mathrm{g} / \mathrm{ml}$ angenommen. Zusätzlich wurde die Reinheit der DNA durch Bestimmung der OD bei $280 \mathrm{~nm}$ kontrolliert. Für reine DNA gilt, dass das Verhältnis von $\mathrm{OD}_{260} \quad \mathrm{zu} \quad \mathrm{OD}_{280} \quad 1,8$ beträgt (SAMBROOK et al., 1989). Verunreinigungen durch Proteine und Phenol sind durch eine deutlich stärkere Absorption bei $280 \mathrm{~nm}$ erkennbar. 


\subsubsection{Enzymatische Modifikation von DNA}

\subsubsection{Restriktionsverdau}

Die aus Prokaryonten isolierten Typ II Restriktionsendonukleasen haben eine hohe Spezifität gegenüber ihrer meist palindromischen Erkennungssequenz im DNADoppelstrang. Dort hydrolysieren diese Enzyme an definierten Stellen die Phosphodiesterbindungen zwischen zwei Basen in beiden Strängen, wobei überhängende oder glatte Enden entstehen können.

Die DNA-Lösungen wurden mit den entsprechenden Restriktionsenzymen und dem vom Hersteller empfohlenen Reaktionspuffer versetzt und für eine Stunde bei angegebener Temperatur inkubiert. Bei einem Doppelrestriktionsansatz wurde ein für beide Enzyme geeigneter Puffer verwendet. Da im Falle einer späteren Ligation von linearisierten Plasmiden und DNA-Fragmenten letztere in einem fünffachen molaren Überschuss vorliegen sollten, ist hier bereits an die entsprechenden Mengenverhältnisse und zu erwartende Verluste zu denken.

\subsubsection{Dephosphorylierung von DNA-Fragmenten}

Um die Religation restriktionsverdauter Vektor-DNA zu vermeiden, wurden die 5'-Phosphatgruppen enzymatisch mit Calf Intestine Alkaline Phosphatase (CIAP) abgespalten. Den entsprechenden Restriktionsansätzen wurden $1 \mu$ CIAP (1U/ $\mu 1)$ direkt zugegeben. Der Ansatz wurde 30 Minuten bei $37^{\circ} \mathrm{C}$ inkubiert und anschließend aufgereinigt.

\subsubsection{Ligation von DNA}

Die T4-DNA-Ligase katalysiert unter ATP-Verbrauch die Bildung von Phosphodiesterbindungen zwischen 5' -Phosphat-, und 3'- Hydroxyl-Enden von DNA. Im Rahmen dieser Arbeit wurden restriktionsverdaute DNA-Fragmente, die Inserts, in restriktionsverdaute, linearisierte und dephosphorylierte Plasmide ligiert. Laut Angabe des Herstellers sind pro Ansatz 100 ng Plasmid sowie bis zu einem fünffachen molaren Überschuss an Insert einzusetzen. Dies ist bereits vor dem Restriktionsverdau zu beachten gewesen, da unter anderem im Verlauf des Restriktionsverdaus und der Dephoshorylierung Verluste an DNA-Mengen aufgetreten sind. Die entsprechenden 
Mengen an DNA und Puffer wurden auf ein Volumen von $19 \mu 1$ gebracht, $1 \mu 1$ Ligase $(5 \mathrm{U} / \mu \mathrm{l})$ hinzugegeben und der Ansatz für $1 \mathrm{~h}$ bei RT inkubiert.

\subsubsection{Transformation von E. coli DH5a}

Konstruierte oder durch Kooperationspartner erhaltene Plasmide wurden zunächst in kompetente E. coli DH5a-Zellen transformiert. Der Stamm eignet sich gut zu Klonierungszwecken, weil ihm z.B. Endonukleasen fehlen (YANNISCH-PERRON et al., 1985). Von transformierten E. coli DH5 $\alpha$ wurden Kryokulturen angelegt (2.3.1), um die Plasmide zu lagern. Bei Bedarf wurden über Nacht Kulturen in LB-Medium angeimpft und die Plasmide isoliert (2.4.3).

\subsubsection{Anlegen kompetenter Zellkulturen}

Eine Hauptkultur (250 ml SOB in 11 Schikanekolben) wurde mit $1 \mathrm{ml}$ einer exponentiell wachsenden E. coli DH5 $\alpha$ Vorkultur beimpft und bei $18^{\circ} \mathrm{C}$ und 150 upm in einem Rundschüttler bis zu einer $\mathrm{OD}_{600}$ von $0,6-0,7$ angezogen. Nach 10 min auf Eis wurden die Zellen durch Zentrifugation geerntet $\left(10 \mathrm{~min}, 2500 \times \mathrm{g}, 4{ }^{\circ} \mathrm{C}\right)$. Anschließend wurde das Zellpellet in $80 \mathrm{ml}$ eiskaltem Transformationspuffer vorsichtig resuspendiert, weitere $10 \mathrm{~min}$ auf Eis gestellt und noch einmal abzentrifugiert. Das Pellet wurde in $20 \mathrm{ml}$ kaltem Transformationspuffer aufgenommen, mit 1,4 ml DMSO (Endkonzentration: $7 \%(\mathrm{v} / \mathrm{v})$ ) versetzt, sorgfältig gemischt, erneut auf Eis gestellt und in Aliquots à $200 \mu \mathrm{l}$ auf vorgekühlte Eppendorf-Gefäße verteilt. Die Zellen wurden sofort in flüssigem Stickstoff eingefroren und bei $-70{ }^{\circ} \mathrm{C}$ gelagert.

\subsubsection{Transformation durch Hitzeschock}

Eppendorf-Gefäße mit $200 \mu \mathrm{l}$ der eingefrorenen kompetenten Zellen wurden 5 min auf Eis aufgetaut, mit dem $\mathrm{zu}$ transformierenden Plasmid vermischt (vollständige Ligationsansätze mit ca. 10 - 150 ng DNA, bzw. Retransformationen mit 1 ng DNA) und für 30 Minuten auf Eis inkubiert. Nach einem Hitzeschock von 1 min $45 \mathrm{~s}$ bei $42{ }^{\circ} \mathrm{C}$ wurden die Zellen nochmals für 5 min auf Eis inkubiert. Nach Zugabe von $600 \mu \mathrm{l}$ LB-Medium wurde der Ansatz $1 \mathrm{~h}$ bei $37^{\circ} \mathrm{C}$ zur Ausprägung der Selektionsmarker inkubiert. $100 \mu \mathrm{l}$ und der aufkonzentrierte Rest wurden auf Agarplatten unter Selektivbedingungen ausplattiert und über Nacht bei $37^{\circ} \mathrm{C}$ inkubiert. 


\subsubsection{Elektroporation von G. oxydans $621 \mathrm{H}$}

Plasmide wurden via Elektroporation in G. oxydans $621 \mathrm{H}$ eingebracht, hierfür wurde eine nach MOSTAFA et al. (2002) modifizierte Methode angewandt.

\subsubsection{Herstellung von Elektroporationszellen}

Eine Übernachtkultur von G. oxydans $621 \mathrm{H}$ wurde in Elektroporations-Medium (2.2.6) inkl. Cefoxitin angezogen. In einem $500 \mathrm{ml}$ Erlenmeyerkolben wurde eine Hauptkultur von $100 \mathrm{ml}$ Volumen auf eine $\mathrm{OD}_{600}$ von 0.15 angeimpft und bei $30^{\circ} \mathrm{C}$ und $170 \mathrm{upm}$ auf einem Rundschüttler inkubiert, bis die $\mathrm{OD}_{600}$ der Kultur zwischen 0,8 und 0,9 lag. $\mathrm{Ab}$ dem Zeitpunkt der Zellernte wurden die Zellen auf Eis gehalten und nur gekühlte Lösungen verwendet. Durch Zentrifugation mit $2200 \times \mathrm{g}$ bei $4{ }^{\circ} \mathrm{C}$ für $10 \mathrm{~min}$ wurde die Zellkultur pelletiert, der Überstand entfernt und die Zellkultur dreimal mit HEPES Puffer gewaschen. Das erhaltene Pellet wurde in $250 \mu 1 \mathrm{mM}$ HEPES Puffer resuspendiert. Pro $100 \mu 1$ Zellsuspension wurden $30 \mu 1$ einer 50 \%igen Glycerol-Lösung hinzugegeben und vorsichtig gemischt. In vorgekühlte $1,5 \mathrm{ml}$ Eppendorf-Gefäße wurden jeweils $50 \mu \mathrm{l}$ der Zellsuspension aliquotiert, in flüssigem Stickstoff eingefroren und bei $-80{ }^{\circ} \mathrm{C}$ gelagert.

\subsubsection{Transformation durch Elektroporation}

Die eingefrorenen Elektroporationszellen wurden auf Eis aufgetaut. Nach Zugabe von 100 ng DNA-Lösung wurde der Ansatz in eine vorgekühlte, sterile Elektroporationsküvette überführt und für $10 \mathrm{~min}$ auf Eis inkubiert. Als Einstellung für die Elektroporation wurden folgende Bedingungen gewählt:

$\begin{array}{lcl}\text { Kapazität } & 25 & \mu \mathrm{F} \\ \text { Spannung } & 2,5 & \mathrm{kV} \\ \text { Widerstand } & 200 & \Omega\end{array}$

Die sich ergebenden Entladungszeiten sollten zwischen 4,5 und 5 ms liegen. Nach der Elektroporation wurden die Ansätze für 10 min auf Eis gehalten und anschließend mit $800 \mu$ Elektroporations-Medien vermischt. Für mindestens 8 h oder über Nacht wurden die Ansätze in $15 \mathrm{ml}$ Schraubdeckel-Röhrchen bei $30^{\circ} \mathrm{C}$ auf einem Rundschüttler mit 
200 upm inkubiert. Anschließend wurden jeweils $200 \mu 1$ der Zellkultur pro Agar-Platte ausplattiert und diese bei $30^{\circ} \mathrm{C}$ für einige Tage inkubiert, bis die ersten Kolonien zu erwarten waren.

\subsubsection{Lösungen für das Arbeiten mit DNA}

\section{Agarosegel $1 \%$}

Agarose

$1 \times$ TAE-Puffer ad $100 \mathrm{ml}$

DNA-Farbmarker $5 \times$

Glycerin (100\%)

TAE $(50 \times)$ $200 \mu 1$

Bromphenolblau $10 \mathrm{mg}$

Xylencyanol $10 \mathrm{mg}$

$\mathrm{H}_{2} \mathrm{O}$

\section{Ethidiumbromid-Färbebad}

Ethidiumbromidlösung $(10 \mathrm{mg} / \mathrm{ml})$

$\mathrm{H}_{2} \mathrm{O}$ ad $500 \mathrm{ml}$

\section{TAE-Puffer $50 \times$}

Tris

Essigsäure (100\%) $57,1 \mathrm{ml}$

EDTA $(0,5 \mathrm{M}, \mathrm{pH} 8,0)$

$100 \mathrm{ml}$

$\mathrm{H}_{2} \mathrm{O}$ ad $1000 \mathrm{ml}$

\section{Transformationspuffer}

HEPES

$\mathrm{CaCl}_{2} \cdot 2 \mathrm{H}_{2} \mathrm{O}$ $2,21 \mathrm{~g}$

$\mathrm{KCl}$ $1,14 \mathrm{~g}$

$\mathrm{MnCl}_{2} \cdot 4 \mathrm{H}_{2} \mathrm{O}$ $10,89 \mathrm{~g}$

$\mathrm{H}_{2} \mathrm{O}$ ad $1000 \mathrm{ml}$ 


\subsection{Arbeiten mit Proteinen}

Im Rahmen dieser Arbeit wurden Antikörper gegen die große UE der membranständigen PQQ-abhängigen Dehydrogenase GOX0854 und die große UE der Quinol-Oxidase des bo3-Typs GOX1912 hergestellt, um damit ImmunogoldMarkierungen und Western-Blot Analysen durchzuführen. Aktivitätstests membranständiger, PQQ-abhängiger Dehydrogenasen, sowie die für die Arbeit mit Proteinen erforderlichen Routinemethoden wie Proteinmengenbestimmungen und Aufreinigungen sind in diesem Kapitel beschrieben. Abschließend sind alle Lösungen aufgelistet, die aus mehr als einer Komponente zusammengesetzt sind.

\subsubsection{Bestimmung der Proteinmenge}

Die Proteinmengenbestimmung erfolgte nach einer kolorimetrischen Methode, dessen Prinzip darin besteht, dass der Farbstoff Coomassie Brilliant Blue R250 spezifisch an Tyrosinseitenketten der Proteine bindet (BRADFORD, 1976). Durch diese Bindung ändert Coomassie Brilliant Blue R250 seine Absorptionseigenschaften und besitzt nun ein Absorptionsmaximum bei einer Wellenlänge von $595 \mathrm{~nm}$. Die Lichtabsorption des gebundenen Komplexes ist proportional zur Proteinmenge in der Probe, innerhalb einer durch ein Photometer gemessene Absorption von 0,1 bis 1 ist diese Relation linear. Der Linearitätsfaktor wird mit Hilfe einer BSA-Stammlösung und daraus hergestellten definierten Proteinmengen über eine Eichkurve ermittelt.

Für eine Messung wurden $980 \mu 1$ einer 1:5 verdünnten Bradfordreagenz-Stammlösung mit $20 \mu$ Probe in einer Plastikküvette gemischt und 15 min im Dunkeln bei RT inkubiert. Die Extinktion wurde am Photometer bei $\lambda=595 \mathrm{~nm}$ gemessen und die Extinktion des analog zur Probe behandelten Leerwertes, angesetzt mit $20 \mu 1$ Puffer in dem auch das Protein gelöst war, abgezogen.

\subsubsection{Denaturierende Gelelektrophorese}

Die denaturierende Polyacrylamid-Gelelektrophorese (SDS-PAGE) nach LAEMMLI (1970), in deren Verlauf Proteine nach ihrem Molekulargewicht aufgetrennt werden können, diente zum einen der Untersuchung von Proteinrohextrakten oder um diese für eine Western-Blot Analyse vorzubereiten. Eine weitere Anwendung war die Vorbereitung von Proben für die Massenspektroskopie. Das Polyacrylamidgel, 
bestehend aus Trenn- und Sammelgel, wurde in einer Minigelkammer gegossen. Vor dem Zusammenbau der Gelkammer wurden die Glasplatten mit Reinigungsmittel gewaschen, mit klarem Wasser gespült und anschließend mit 70 \%igem Ethanol gereinigt. Das Trenn- sowie das Sammelgel wurden in $50 \mathrm{ml}$ Sarstedt-Röhrchen angesetzt. Die Polymerisation wurde durch die Zugabe des TEMED und anschließendem kurzem Schwenken gestartet. Das Trenngel wurde bis ca. $1 \mathrm{~cm}$ unterhalb der späteren Lage der Taschenböden gegossen und mit Isopropanol überschichtet. Nachdem das Trenngel ausgehärtet und das Isopropanol entfernt worden war, konnte das Sammelgel gegossen und der Kamm eingesetzt werden. Dieser wurde erst entfernt, als auch das Sammelgel ausgehärtet, die Gelkammer in die Elektrophoreseapparatur eingebaut und mit Laufpuffer überschichtet worden ist. Überhängende Gelreste wurden entfernt und die Geltaschen mit Laufpuffer mit Hilfe einer Hamilton-Spritze gespült. Nun konnten die Proben in die Taschen gefüllt werden. Hierfür wurden $80 \mu \mathrm{l}$ des Rohextrakts mit $20 \mu \mathrm{l}$ SDS-Probenpuffer versetzt und vor dem Auftragen 2 min auf $95^{\circ} \mathrm{C}$ erhitzt und anschließend auf Eis gestellt. Zusätzlich wurden $5 \mu$ l eines Prestained-Markers in eine Tasche pipettiert. Die Auftrennung der Proteine im Gel erfolgte für ca. $1 \mathrm{~h}$ bei $120 \mathrm{~V}$. Nach erfolgter Elektrophorese wurde das Gel für $30 \mathrm{~min}$ in einer Coomassieblau-Färbelösung gefärbt und anschließend über Nacht in Entfärbelösung (10 \%ige Essigsäure) schwenkend entfärbt. Nach der Coomassie-Färbung wurde das Gel eingescannt und Proteinbanden ggf. mit einer sterilen Rasierklinge ausgeschnitten.

\subsubsection{Western-Blot}

Die Western-Blot Analyse, bei der Proteine aus einem Polyacrylamid-Gel auf eine Polyvinylidenfluorid (PVDF) - Membran übertragen werden, um dort anschließend das Zielprotein durch Antikörper detektieren zu können, wurde nach STARK (1979) modifiziert durchgeführt.

\subsubsection{Zellernte für die Western Blot-Analyse}

Zellkulturen wurden entsprechend den Versuchen, oder wie in Kap. 2.3 beschrieben, angezogen. Anschließend wurden die Zellen durch zentrifugieren geerntet (8000 upm $\triangleq$ $8873 \times \mathrm{g}, 4^{\circ} \mathrm{C}, 10 \mathrm{~min}$ ), in Zellaufschlusspuffer (ZAP) resuspendiert und erneut 
zentrifugiert. Die dadurch erhaltenen Zellpellets wurden entweder eingefroren oder sofort weiterverarbeitet.

\subsubsection{Zellaufschluss mittels Ultraschall}

Die Zellpellets wurden mit möglichst geringem Volumen ZAP $(250-1000 \mu \mathrm{l})$ in einem Eppendorf-Gefäß resuspendiert. Anschließend erfolgte der Aufschluss der Zellen per Ultraschall. Hierfür wurde Leistung (Amplitude) auf $60 \%$ und das Intervall auf 0,6 s eingestellt. Die Proben wurden für $6 \times 10 \mathrm{~s}$ sonifiziert, unterbrochen durch $10 \mathrm{~s}$ dauernde Pausen, in denen die Probe auf Eis gestellt wurde. Ultraschall erzeugt rasch wechselnde Druckänderungen, diese bewirken ein Zerreißen der Membranen und Zellwände beschallter Zellen. Mit Ultraschall kann ein schneller Zellaufschluss erreicht werden, wobei allerdings viel Wärme freigesetzt wird. Anschließend wurden die Zelltrümmer mit 13,000 upm $(16,200 \times \mathrm{g})$ bei $4{ }^{\circ} \mathrm{C}$ für $30 \mathrm{~min}$ abzentrifugiert. Nach der Bestimmung der Proteinmenge (2.5.1) wurde eine SDS-PAGE durchgeführt (2.5.2).

\subsubsection{Western Blot-Analyse}

Mittels einer Semi-dry-Blot-Anlage wurden Proteine von einem Polyacrylamidgel auf eine PVDF-Membran übertragen, die zuvor in Methanol für 1 min äquilibriert wurde. Der Transfer erfolgte von unten nach oben, deshalb ergab sich folgender Aufbau: Zunächst drei Lagen Whatman-Papier, dann das Polyacrylamidgel, darauf die aktivierte PVDF-Membran und zum Abschluss noch einmal drei Lagen Whatman-Papier. Das Whatman-Papier wurde zuvor mit Transferpuffer getränkt. Die Proteine wurden durch ein elektrisches Feld mit einer Stromdichte von $0,8 \mathrm{~mA} / \mathrm{cm}^{2}$ für $1 \mathrm{~h}$ auf die PVDFMembran übertragen. Anschließend ist die Membran über Nacht bei $12{ }^{\circ} \mathrm{C}$ in Blotto auf einem Plattformschüttler geschwenkt worden, um unspezifische Bindungsstellen auf der Membran zu blocken. Die Membran wurde mit dem primären Antikörper, verdünnt in Blotto $(1: 1000$ bis $1: 10,000)$, für $3 \mathrm{~h}$ bei RT schwenkend inkubiert. Der primäre IgGAntikörper ist gegen das $\mathrm{zu}$ untersuchende Protein gerichtet und in immunisierten Kaninchen hergestellt worden. Anschließend ist die Membran dreimal mit Blotto für 30 min gewaschen worden, bevor sie mit dem sekundären Antikörper, verdünnt in Blotto $(1: 100,000)$ für 30 min inkubiert wurde. Der sekundäre Antikörper ist ein AntiKaninchen IgG-Antikörper und stammt aus der Ziege. An diesen Antikörper ist das Enzym Alkalische Phosphatase gekoppelt. Ungebundener Sekundär-Antikörper wurde 
durch dreimal 20minütiges Waschen mit Blotto entfernt. Die Membran wurde anschließend kurz mit vollentsalztem Wasser gespült und zur Äquilibrierung mindestens 5 min in Puffer III geschwenkt. Die Membran wurde zwischen zwei Folien gelegt und mit einem Substrat der Alkalischen Phosphatase 1,2-Dioxetanen-Phosphat (CDP-Star), $10 \mu \mathrm{l}$ in $1 \mathrm{ml}$ kurz inkubiert und das durch Chemilumineszenz entstehende Licht mittels eines ChemoCam Imager dokumentiert.

\subsubsection{Bestimmung der Aktivität membranständiger Dehydrogenasen}

Die Aktivität membranständiger Dehydrogenasen, welcher die bei der Oxidation frei werdenden Elektronen via PQQ dem Ubiquinon-Pool zuführen, kann mit diesem Test bestimmt werden. Dabei werden die Elektronen über Phenazinmethosulfat (PMS) auf den artifiziellen Elektronenakzeptor Dichlorphenolindophenol (DCPIP) übertragen, dessen Reduktion photometrisch verfolgt werden kann (VOSS et al., 2010).

\subsubsection{Zellernte und die Trennung von Cytoplasa- und Membran-Fraktion}

Zellkulturen wurden entsprechend den Versuchen, oder wie in Kap. 2.3 beschrieben, angezogen. Durch die Zentrifugation bei 8000 upm $(8873 \times \mathrm{g})$ und $4{ }^{\circ} \mathrm{C}$ für $10 \mathrm{~min}$ wurden Zellpellets erhalten. Diese wurden in $10 \mathrm{mM}$ Tris-HCl Puffer mit einem $\mathrm{pH}$ Wert von 7,2 (Tris-Puffer) resuspendiert und erneut zentrifugiert. Nach einmaliger Wiederholung sind die gewaschenen Zellpellts direkt weiterverarbeitet, oder bei $-20{ }^{\circ} \mathrm{C}$ weggefroren worden. Um möglichst unbeschadete Zellpellets zur Verfügung zu haben, wurden eingefrorene Zellpellets spätestens nach $3 \mathrm{~d}$ verwendet.

Zur Gewinnung von Cytoplasma- und Membranfraktion wurde das Pellet zunächst in Waschpuffer resuspendiert, es wurden pro Gramm Nassgewicht $10 \mathrm{ml}$ Tris-Puffer zugegeben. Der Zellaufschluss erfolgte durch zweimalige Passage durch eine „French Pressure Cell“, mit einem Aufschlussdruck von 18,000 psi.

Das Lysat wurde zur Abtrennung von Zelltrümmern bei 8500 upm $(10,000 \times \mathrm{g})$ und $4{ }^{\circ} \mathrm{C}$ für 30 min zentrifugiert. Der gewonnene Überstand wurde in Ultrazentrifugationsbecher überführt und mit 35,000 upm $(123,000 \times \mathrm{g})$ und $4{ }^{\circ} \mathrm{C}$ für $2 \mathrm{~h}$ zentrifugiert. Der Überstand entsprach der Cytoplasmafraktion, das erhaltene Pellet wurde vorsichtig in Tris-Puffer resuspendiert und nochmals für eine Stunde bei 35000 upm $(123,000 \times \mathrm{g})$ und $4{ }^{\circ} \mathrm{C}$ zentrifugiert. Das aus der zweiten Zentrifugation 
resultierende Pellet wurde als Membranfraktion betrachtet und in 300 - $1000 \mu$ TrisPuffer aufgenommen.

\subsubsection{Bestimmung der Proteinkonzentration}

Die Bestimmung der Proteinkonzentration von Membranfraktionen erfolgte nach der Methode von BRADFORD (1976), Kap 2.2.5.1 mit der von PESTOV \& RYDSTRÖM (2007) beschriebenen Modifikation. Um die Präzipitation von Membranproteinen zu verhindern, erfolgte die Inkubation der Membransuspension mit $1 \%$ Octylglucosid. Dies ermöglicht eine genauere Bestimmung der Proteinkonzentration. 9,5 $\mu 1$ Membransuspension wurden mit 0,5 $\mu$ l Octylglucosid (20\%) gemischt und für eine Minute bei Raumtemperatur inkubiert, bevor der Proteingehalt der Probe bestimmt wurde.

\subsubsection{Enzymaktivitätstest}

Die Reduktion des artifiziellen Elektronenakzeptors DCPIP wurde bei einer Wellenlänge von $578 \mathrm{~nm}$ und $25^{\circ} \mathrm{C}$ in $1 \mathrm{ml}$ Plastikküvetten in einem Zweistrahlspektralphotometer mittels eines Computerprogramms aufgezeichnet. Nachdem sich eine stabile Grundlinie eingestellt hatte, wurde der Test durch die Zugabe des Substrats gestartet. Nun wurde die durch die Reduktion von DCPIP hervorgerufene Extinktionsabnahme für max. 5 min verfolgt. Die spezifische Aktivität gegenüber des eingesetzten Substrates wurde unter Einbeziehung des linear verlaufenden Bereichs der Reaktionskurve, des Extinktionskoeffizienten von DCPIP bei $\mathrm{pH}$ 5,0 und $578 \mathrm{~nm}$ von $5,016 \mathrm{M}^{-1} \mathrm{~cm}^{-1}$ (VOSS et al., 2010) und der Proteinkonzentration bestimmt. Eine Einheit von Enzymaktivität (U) wurde als die Menge an Enzym definiert, die $1 \mathrm{mmol}$ Substrat pro Minute oxidiert.

Die Konzentrationsänderung $\Delta \mathrm{c} / \Delta \mathrm{t}$ wurde mit Hilfe des Lambert-Beer-Gesetz über die gemessene Extinktionsänderung $\Delta \mathrm{E} / \Delta \mathrm{t}$ anhand der Formel (3) ermittelt:

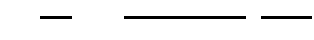


Die Schichtdicke der Küvette d entsprach $1 \mathrm{~cm}$. Zu jeder Versuchsreihe wurde eine Negativkontrolle mit $100 \mu \mathrm{H}_{2} \mathrm{O}_{\text {Millipore }}$ an Stelle des Substrats durchgeführt und in die ermittelten Aktivitäten mit einbezogen.

\section{Enzymaktivität -Testansatz}

$\begin{array}{lrr}\text { PMS } & (10 \mathrm{mM}) & 10,0 \mu 1 \\ \text { DCPIP } & (20 \mathrm{mM}) & 7,5 \mu 1 \\ \text { MacIllvaine Puffer } & \text { (pH 5,0) } & 877,5 \mu 1 \\ \text { Membranfraktion } & 5,0 \mu 1 \\ \text { Substrat } \quad(250 \mathrm{mM}) & 100,0 \mu 1\end{array}$

\subsubsection{Herstellung polyklonaler Antikörper}

Für die Untersuchung von Membranen und membrangebundenen Dehydrogenasen in Essigsäurebakterien wurden im Rahmen dieser Arbeit Antikörper gegen die große Untereinheit der membrangebundenen PQQ-abhängigen Polyol-Dehydrogenase GOX0854 und die große Untereinheit der Quinol-Oxidase des bo3-Typs GOX1912 hergestellt. Es wurden zwei unterschiedliche Methoden angewendet, um die entsprechenden Immunogene zu erhalten. Der Antikörper gegen GOX0854 wurde mittels der homolog überexpremierten Strep-markierten großen Untereinheit gewonnen. Im Falle des GOX1912-Antikörpers wurden unter Zusammenarbeit mit der Firma Eurogentec zwei Peptide als Antigen benutzt.

\subsubsection{Antikörper gegen GOX0854}

Der Stamm $\quad$ upp $\quad$ goox0854/0855 $\cdot$ pBBR1p264-gox0854-Strep/gox0855, im folgenden Gox-0854-Strep genannt, wurde wie im Kap. 2.3 beschrieben angezogen. Um den geeigneten Zeitpunkt zur Ernte der Kultur und dem Aufreinigen von GOX0854Strep mittels Strep-Tactin Säulen zu ermitteln, wurden Kulturen zu verschiedenen Zeitpunkten geerntet und eine SDS-PAGE (2.5.2) durchgeführt. Die entsprechende Proteinlösung wurde aufgereinigt, einer SDS-PAGE unterzogen und die in Frage kommende Bande mittels Massenspektrometrie analysiert (2.5.7). Nach weiteren Aufreinigungen wurde die Immunisierung durch die Fa. Eurogentec durchgeführt. 


\section{Zellanzucht und Ernte}

Für die Aufreinigungen wurden $1000 \mathrm{ml}$ Kultur wie in Kapitel 2.3 beschrieben angezogen. Die Zellen, Überstände, Lysate und letztendlich die Proteinlösungen wurden fortan immer auf Eis gehalten. Die Zellkulturen wurden für 20 min bei 5000 upm (4400 $\times$ g) bei $4{ }^{\circ} \mathrm{C}$ zentrifugiert und die erhaltenen Pellets in kaltem ZAP resuspendiert, vereinigt und erneut pelletiert. Die erhaltenen Pellets wurden entweder bei $-20{ }^{\circ} \mathrm{C}$ weggefroren oder sofort weiterverarbeitet.

\section{GOX0854-Strep Aufreinigung mittels Strep-Tactin Säulen}

Gewaschene Pellets aus $1000 \mathrm{ml}$ Kulturen wurden in $25 \mathrm{ml}$ Puffer W inkl. 0,1\% Triton X 100 (v/v) resuspendiert. Anschließend wurden die Zellen durch zweimalige Passage der French Press bei 18,000 psi Aufschlussdruck aufgeschlossen und die Zelltrümmer mit 8000 upm $(8873 \times \mathrm{g})$ für 30 min bei $4{ }^{\circ} \mathrm{C}$ abzentrifugiert. Der erhaltene Überstand wurde für $1 \mathrm{~h}$ bei $4{ }^{\circ} \mathrm{C}$ mit 35,000 upm $(123,000 \times \mathrm{g})$ ultrazentrifugiert und dieser Überstand, das Lysat, wurde mittels der Strep-Tactin Säule aufgereinigt.

Das Säulenmaterial Strep-Tactin bindet Strep-Tag II Fusionsproteine. Das Säulenmaterial wurde kurz in Puffer W geschwenkt und mittels einer Glaspipette in die gekühlte Säule pipettiert. Die Lagerung der präparierten Säulen und der benutzten Puffer erfolgte bei $4{ }^{\circ} \mathrm{C}$, und die Aufreinigung wurde in einem gekühlten Raum bei ca. $10{ }^{\circ} \mathrm{C}$ durchgeführt. Nachdem der Puffer, in dem das Sephadex-Säulenmaterial lagerte, abgelassen wurde, ist das Säulenmaterial durch den Durchlauf von $2 \mathrm{ml}$ Puffer W inkl. $0.1 \%$ Triton X 100 (v/v) äquilibriert worden. Sukzessive wurde nun das Lysat auf die Säule gegeben und der Durchfluss aufgefangen. Nachdem das Lysat die Säule vollständig passiert hatte, wurde diese mit $5 \times 1 \mathrm{ml}$ Puffer $\mathrm{W}$ inkl. 0,1\% Triton X 100 (v/v) gewaschen und der Durchfluss jedes einzelnen Waschschritts in Eppendorf-Cups gesammelt. Dem Waschen folgte das Eluieren des an dem Säulenmaterial gebundenen GOX0854-Strep mittels des Puffers E, in dem 2,5 mM Desthiobiotin enthalten war. Es wurde mit $7 \times 0,5 \mathrm{ml}$ Puffer E eluiert, und der Durchfluss (das Eluat) jedes einzelnen Elutionsschritts in Eppendorf-Cups gesammelt. Abschließend wurde die Säule rekalibriert. Hierfür wurden sukzessive $15 \mathrm{ml}$ Puffer R durch die Säule laufen gelassen, das Säulenmaterial mit $5 \mathrm{ml}$ Puffer R überschichtet, die Säule am oberen und unteren Ende verschlossen und mit Parafilm umwickelt, um eine Austrocknung bis zur nächsten 
Verwendung der Säule zu vermeiden. Die Säulen wurden mehrfach verwendet, bis sich Qualität und/oder Quantität der Aufreinigung verschlechterten.

\section{SDS-PAGE zur Kontrolle der Aufreinigung}

Die SDS-PAGE wurde im Prinzip wie unter 2.5.2 erläutert durchgeführt. Die aufgetragenen Proben und deren eingesetzten Volumina sind der Tabelle 2.5.1. zu entnehmen.

Tabelle 2.5.1.: SDS-PAGE der Strep-tag Aufreinigung

\begin{tabular}{lccc}
\hline Probe & Volumen & SDS-Probenpuffer 5 & Auftragsvolumen \\
\hline Lysat & $3 \mu 1$ & $0,6 \mu \mathrm{l}$ & $2,5 \mu 1$ \\
Durchfluss & $3 \mu 1$ & $0,6 \mu \mathrm{l}$ & $2,5 \mu \mathrm{l}$ \\
Waschschritt 1 & $3 \mu 1$ & $0,6 \mu 1$ & $2,5 \mu 1$ \\
Waschschritte 2-5 & $24 \mu 1$ & $6 \mu 1$ & $20 \mu 1$ \\
Elutionsschritte 1-7 & $24 \mu 1$ & $6 \mu 1$ & $20 \mu 1$ \\
\hline
\end{tabular}

\section{Immunisierung}

Es sollten pro Antigen zwei Wirtstiere immunisiert werden, in diesem Fall Kaninchen. Es waren zunächst 4 Immunisierungen pro Wirt vorgesehen, verteilt über einen Zeitraum von ca. 2 Monaten (Tab. 2.5.2.).

Tabelle 2.5.2.: Zeitplan der Immunisierung GOX0854

\begin{tabular}{lccccccc}
\hline Tag & 0 & 14 & 28 & 38 & 56 & 66 & 87 \\
Injektion & 1. & 2. & 3. & & 4. & & \\
Blut- & Präimmun- & & & Kleine & & Zweite & Finale \\
Abnahme & serum & & & Blutung & & Blutung & Blutung \\
\hline
\end{tabular}

Injiziert wurden $125 \mu \mathrm{g}$ aufgereinigte Proteinlösung, die in einem Coomassie gefärbten SDS-PAGE Gel-Stück enthalten waren. Vor der SDS-PAGE (2.5.2) war i.d.R. ein Aufkonzentrieren mittels Zentrifugalkonzentrations-Säulen mit einem MWCO von 30,000 Dalton notwendig, da die Gel-Stücke ein Volumen von über 0,5 ml nicht überschreiten sollten. Aufgereinigte Proteinlösung wurde auf die Säule aufgetragen und mit $3000 \times \mathrm{g}$ bei $4{ }^{\circ} \mathrm{C}$ für eine Stunde in einer Zentrifuge mit Swing-out Rotor 
zentrifugiert. Nach der Bestimmung der Proteinkonzentration (2.5.1) wurden die entsprechenden Volumina auf das Gel geladen und nach erfolgtem Lauf die Banden mit einem Skalpell ausgeschnitten. Die Banden wurden in 1,5 ml Mikro-Schraubröhren überführt, mit kaltem und sterilem $\mathrm{H}_{2} \mathrm{O}_{\text {Millipore }}$ überschichtet und gekühlt zur Fa. Eurogentec verschickt.

\subsubsection{Antikörper gegen GOX1912}

Zur Herstellung des Antikörpers gegen die große Untereinheit der Quinol-Oxidase des bo3-Typs GOX1912 wurden zwei synthetisierte Oligopeptide als Antigene eingesetzt. Die Auswahl der entsprechenden Oligopeptide wurde von der Fa. Eurogentec hinsichtlich ihrer zu erwartenden Immunogenität getroffen und vor Beginn der Immunisierung synthetisiert. Hierfür war es notwendig, der Fa. Eurogentec die Primärsequenz des Zielproteins zur Verfügung zu stellen, was im Falle des komplett sequenzierten Gluconobacter oxydans 621H möglich war (PRUST et al., 2005).

\section{Immunisierung}

Wie bei der Herstellung des GOX0854-Antikörpers sollten auch hier wieder zwei Kaninchen immunisiert werden (2.5.5.1). Als Antigene wurden hierfür zwei 16 Aminosäuren große Oligopeptide benutzt, die jeweils beiden Wirtstieren injiziert wurden. Es waren zunächst 4 Immunisierungen pro Wirtstier vorgesehen, verteilt über einen Zeitraum von ca. 2 Monaten (Tab. 2.5.3.).

Tabelle 2.5.3.: Zeitplan der Immunisierung GOX1912

\begin{tabular}{lccccccc}
\hline Tag & 0 & 14 & 28 & 38 & 56 & 66 & 87 \\
Injektion & 1. & 2. & 3. & & 4. & & \\
Blut- & Präimmun- & & & Kleine & & Zweite & Finale \\
Abnahme & serum & & & Blutung & & Blutung & Blutung \\
\hline
\end{tabular}

Der Aufbau von Antikörpern gegen die eingesetzten Antigene durch das Immunsystem der Wirtstiere wurde mittels Western Blot-Analyse (2.5.3.3) verfolgt. Das nach der finalen Blutung erhaltene Serum musste durch die Fa. Eurogentec gegen die synthetisierten Antigene aufgereinigt werden. Es wurden $50 \mathrm{ml}$ Serum mittels $10 \mathrm{mg}$ immobilisiertem Peptid 1 aufgereinigt (siehe Kap. 3.1.1.2) und der Antikörper in einer 
Konzentration von $0,27 \mathrm{mg} / \mathrm{ml}$ in PBS, welches $0,01 \%(\mathrm{w} / \mathrm{v})$ Thiomersal und 0,1 $\%(w / v)$ BSA enthielt, gelöst.

\subsubsection{Trypsin-Verdau für die Massenspektrometrie}

Die nach erfolgter denaturierender Gelelektrophorese (2.5.2) zu untersuchenden Banden wurden in ca. $2 \mathrm{~mm}$ große Stückchen geschnitten, mit $30 \mu \mathrm{l}$ Acetonitril für $10 \mathrm{~min}$ bei RT inkubiert und anschließend in einer Speed-Vac getrocknet. In $150 \mu 10$ mM DTT, gelöst in $100 \mathrm{mM} \mathrm{NH} \mathrm{HCO}_{3}$, wurden die Gelstückchen bei $56^{\circ} \mathrm{C}$ für $1 \mathrm{~h}$ inkubiert. Diese Lösung wurde dann durch $150 \mu 155 \mathrm{mM}$ Iodacetamid, ebenfalls gelöst in $100 \mathrm{mM} \mathrm{NH} \mathrm{HCO}_{3}$, ersetzt und die Ansätze für 45 min bei RT im Dunkeln inkubiert. Die anschließende Zugabe von $150 \mu 100 \mathrm{mM} \mathrm{NH}_{4} \mathrm{HCO}_{3}$, die Inkubation für $10 \mathrm{~min}$ bei RT, und das Ersetzen des Ammonium-Hydrogencarbonats durch $150 \mu$ l Acetonitril für 10 min bei RT wurde zweimal durchgeführt. Das Acetonitril wurde entfernt (SpeedVac, $10 \mathrm{~min}$ ), bevor zu den Gelstückchen $30 \mu \mathrm{l}$ Trypsinverdau-Puffer pipettiert werden konnte. Die Inkubation erfolgte für $45 \mathrm{~min}$ auf Eis. Anschließend wurde der Trypsinverdau-Puffer entfernt und durch $30 \mu \mathrm{l} 50 \quad \mathrm{mM} \quad \mathrm{NH}_{4} \mathrm{HCO}_{3}$ ersetzt. Die Inkubation erfolgte bei $37^{\circ} \mathrm{C}$ über Nacht.

Von nun an wurden alle jeweiligen Überstände in einem frischen Eppendorfgefäß gemeinsam gesammelt. Die Ansätze wurden für 1 min mit 13000 upm $(16200 \times \mathrm{g})$ abzentrifugiert und der Überstand durch $30 \mu 120 \mathrm{mM} \mathrm{NH}_{4} \mathrm{HCO}_{3}$ ersetzt. Nach einer Inkubation von $10 \mathrm{~min}$ bei RT, wurde dieser Überstand wiederum durch $30 \mu 1$ $50 \%$ Acetonitril $/ 5 \%$ Ameisensäure-Lösung ersetzt, für 20 min bei RT inkubiert und die Ansätze mit 13000 upm $(16200 \times \mathrm{g})$ für 1 min zentrifugiert. Diese Extraktion mit der Acetonitril/Ameisensäure-Lösung wurde noch zweimal wiederholt, bevor alle gesammelten Überstände in der Speed-Vac getrocknet und das Proteinpellet der Massenspektrometrie zugeführt werden konnte.

\subsubsection{Massenspektrometrie}

Die Massenspektrometrie wurde von Dr. Oliver Valerius, Abteilung für molekulare Mikrobiologie und Genetik der Georg-August-Universität Göttingen, durchgeführt. 


\subsubsection{Lösungen zum Arbeiten mit Proteinen}

\section{Blotto}

TBS $10 \times$

$100 \mathrm{ml}$

Magermilchpulver $25 \mathrm{~g}$

Tween 20

$\mathrm{H}_{2} \mathrm{O}$ ad $1000 \mathrm{ml}$

\section{Färbelösung}

Coomassie Brillant Blue R250 0,5 \%

Essigsäure

$10 \%$

Methanol

\section{MacIllvaine Puffer}

$\mathrm{Na}_{2} \mathrm{HPO} 4 \cdot \mathrm{H}_{2} \mathrm{O}(200 \mathrm{mM})$

$51,5 \mathrm{ml}$

Citronensäure-Monohydrat (100 mM)

$48,5 \mathrm{ml}$

\section{Puffer E}

Tris- $\mathrm{HCl}$

$100 \mathrm{mM}$

$\mathrm{NaCl}$

$150 \mathrm{mM}$

EDTA

$1 \mathrm{mM}$

Desthiobiotin

$2,5 \mathrm{mM}$

pH-Wert

$\mathrm{pH} 8,0$

\section{Puffer R}

Tris- $\mathrm{HCl}$

$100 \mathrm{mM}$

$\mathrm{NaCl}$

$150 \mathrm{mM}$

EDTA

$1 \mathrm{mM}$

HABA

$1 \mathrm{mM}$

pH-Wert

pH 8,0 


\section{Puffer W}

Tris- $\mathrm{HCl}$

$100 \mathrm{mM}$

$\mathrm{NaCl}$

$150 \mathrm{mM}$

EDTA

$1 \mathrm{mM}$

pH-Wert

$\mathrm{pH} 8,0$

\section{PBS}

$\mathrm{NaCl}$

$140 \mathrm{mM}$

Na-Phosphat

$10 \mathrm{mM}$

pH-Wert

pH 7,4

\section{Proteinlaufpuffer $10 \times$}

Tris

Glycin

SDS

$\mathrm{H}_{2} \mathrm{O}$

ad $1000 \mathrm{ml}$

Sammelgel für die SDS-PAGE

$30 \%$ Acrylamid-Bisacrylamid $(37,5: 1)$

$$
\begin{gathered}
1,3 \mathrm{ml} \\
0,87 \mathrm{ml} \\
6,83 \mathrm{ml} \\
50 \mu 1 \\
100 \mu \mathrm{l} \\
20 \mu \mathrm{l}
\end{gathered}
$$$$
\mathrm{H}_{2} \mathrm{O}
$$$$
20 \% \text { SDS }
$$

$10 \%$ APS

TEMED

\section{SDS-Equilibrierungspuffer}

Tris- $\mathrm{HCl} \mathrm{pH} 8,8$

Harnstoff

Glycerin

$30 \%$

SDS

Bromphenolblau 
SDS-Probenpuffer $5 \times$

Glycerin $3 \mathrm{ml}$

$1 \mathrm{M}$ Tris- $\mathrm{HCl} \mathrm{pH} 7,0$

$1,4 \mathrm{ml}$

$\mathrm{H}_{2} \mathrm{O}$ $2 \mathrm{ml}$

$20 \%$ SDS

$2 \mathrm{ml}$

$\beta$-Mercaptoethanol

$1,6 \mathrm{ml}$

Bromphenolblau

TBS $10 \times$

Tris

$60 \mathrm{~g}$

$\mathrm{NaCl}$

$90 \mathrm{~g}$

$\mathrm{H}_{2} \mathrm{O}$ ad $1000 \mathrm{ml}$

pH-Wert (mit $\mathrm{HCl}$ einzustellen)

\section{Transfer-Puffer}

Tris

$15,1 \mathrm{~g}$

Glycin

$72,1 \mathrm{~g}$

Methanol

$750 \mathrm{ml}$

$\mathrm{H}_{2} \mathrm{O}$ ad $5000 \mathrm{ml}$

Trenngel für die SDS-PAGE

$30 \%$ Acrylamid-Bisacrylamid (37,5:1)

$$
\begin{gathered}
4 \mathrm{ml} \\
2,6 \mathrm{ml} \\
3,2 \mathrm{ml} \\
50 \mu 1 \\
100 \mu \mathrm{l} \\
10 \mu \mathrm{l}
\end{gathered}
$$$$
\text { 1,5 M Tris-HCl pH 8,8 }
$$$$
\mathrm{H}_{2} \mathrm{O}
$$

$20 \%$ SDS

$10 \%$ APS

TEMED

\section{Tris-Puffer}

Tris $10 \mathrm{mM}$

pH-Wert

$\mathrm{pH} \mathrm{7,2}$ 


\section{Trypsin-Lösung}

Trypsin (5000 U/mg)

Trypsin-Resuspendierungspuffer

\section{Trypsinverdau-Puffer}

Trypsin-Lösung

$50 \mathrm{mM} \mathrm{NH}_{4} \mathrm{HCO}_{3}$

\section{Zellaufschlusspuffer (ZAP)}

Tris- $\mathrm{HCl}$

$\mathrm{NaCl}$

$200 \mathrm{mM}$

pH-Wert (mit $\mathrm{HCl}$ einzustellen)

\subsection{Mikroskopie}

In dieser Arbeit wurden Licht- und Epifluoreszenzmikroskopische Methoden angewendet, um die Arbeit zu einer translationalen Fusion von einer membranständigen Dehydrogenase und einem fluoreszierenden Protein $\mathrm{zu}$ begleiten. Die Transmissionselektronenmikroskopie (TEM) stand im Mittelpunkt der Untersuchung von intracytoplasmatischen Membranen (ICM) und der Immunogold-Markierung von Enzymen, die an der unvollständigen Oxidation an- und innerhalb der Cytoplasmamembran von Gluconobacter oxydans $621 \mathrm{H}$ beteiligt sind. Am Ende dieses Kapitels sind alle Lösungen aufgelistet, die aus mehr als einer Komponente zusammengesetzt sind.

\subsubsection{Lichtmikroskopie}

Die lichtmikroskopischen Untersuchungen fanden unter Verwendung des Phasenkontrastes mit einem $20 \times, 40 \times$ oder $100 \times$ Objektiv statt, was in Kombination mit einem $10 \times$ Okular zu einer 200-, 400- oder 1000-fachen Vergrößerung führte. Für die Dokumentation wurde eine digitale CCD-Kamera verwendet. 


\subsubsection{Epifluoreszenzmikroskopie}

Die Epifluoreszenzmikroskopie wurde zur Darstellung des fluoreszierenden Proteins evoGlowPp1 (DREPPER et al. 2010) verwendet. Die Proben wurden mit dem Filtersatz 09 und einer Hochdruck-Quecksilberlampe in Verbindung mit einem Axioskop Photomikroskop analysiert und mit einer CCD-Digitalkamera dokumentiert. In allen im Rahmen dieser Arbeit dargestellten fluoreszenzmikroskopischen Aufnahmen betrug die Belichtungszeit 2 s. In der Nachbearbeitung der Bilder wurde darauf geachtet, dass die Intensität der Fluoreszenz nicht beeinflusst wurde, um einen Vergleich der Fluoreszenz untereinander zu ermöglichen.

Zur Vorbereitung der Proben wurden Kulturen wie in Kap. 2.3 beschrieben angezogen und zu entsprechenden Zeitpunkten $1 \mathrm{ml}$ entnommen. Diese Proben wurden für $1 \mathrm{~min}$ mit 10,000 upm $(9600 \times \mathrm{g})$ bei RT zentrifugiert, der Überstand abgenommen und das Zellpellet in $1 \mathrm{ml}$ PBS resuspendiert und erneut zentrifugiert. Das erhaltene Pellet wurde, je nach optischer Dichte der Kultur, in 15 bis $150 \mu 1$ PBS resuspendiert und $15 \mu 1$ auf ein Objektträger pipettiert, mit einem Deckgläschen versehen und mikroskopiert.

\subsubsection{Transmissionselektronenmikroskopie}

Die Transmissionselektronenmikroskopie (TEM) ermöglicht den Blick in die Zelle, die Auflösungsgrenze liegt bei 0,3 nm. Es können somit Zellkomponenten wie Ribosomen, Einschlusskörper oder Membranen sichtbar gemacht werden. Hierbei treffen beschleunigte Elektronen in einem Vakuum auf das $\mathrm{zu}$ untersuchende Objekt, bei biologischen Proben sind dies Ultradünnschnitte von in Kunstharz eingebetteten Proben mit einer Schichtdicke von ca. $100 \mathrm{~nm}$. Die Beschleunigungsspannung beträgt bei biologischen Proben 60 bis $100 \mathrm{kV}$, das sichtbare Bild ergibt sich durch die vorhandenen, bzw. nicht vorhandenen Wechselwirkungen der Elektronen mit den Atomen in der Probe (HOPPERT, 2003).

\subsubsection{Einbettung prokaryotischer Zellen in Kunstharz}

Im Rahmen dieser Arbeit wurde das Kunstharz LR White benutzt, welches ein späteres Immunogold-Markieren mit IgG-Antikörpern erlaubt (AGARWALA et al., 2009). Die verschiedenen Zellkulturen wurden den Versuchen entsprechend angezogen und durch 
Zentrifugation mit $6000 \mathrm{upm}(5000 \times \mathrm{g})$ bei $4{ }^{\circ} \mathrm{C}$ für $5 \mathrm{~min} \mathrm{zu}$ den gegebenen Zeitpunkten geerntet. Während der nachfolgenden Schritte wurden die Proben kontinuierlich auf Eis gelagert. Das erhaltene Pellet wurde einmal mit PBS gewaschen, wobei die Zellen vorsichtig mit einer Glaspipette resuspendiert wurden. Anschließend wurden die Zellen in einer Lösung aus 0,2 \% Glutaraldehyd (w/v) und 0,3\% Formaldehyd (w/v) für mindestens 90 min, meist aber über Nacht, fixiert.

Nach der Fixierung wurden die Zellen dreimal mit kaltem PBS gewaschen, in dem zuvor Glycin in einer Konzentration von $10 \mathrm{mM}$ zugesetzt wurde. Zentrifugiert wurde mit $5000 \times$ g bei $4{ }^{\circ} \mathrm{C}$ für $2 \mathrm{~min} .100 \mu \mathrm{l}$ des gewaschenen Pellets wurden mit gleichem Volumen $58{ }^{\circ} \mathrm{C}$ warmen, $2 \%$ igem Bacto-Agar in PBS mittels Pipette und einer abgeschnittenen Pipettenspitze vorsichtig vermischt, um die Zellen nicht durch auftretende Scherkräfte in Mitleidenschaft zu ziehen. Nach dem Mischen und ggf. einem kurzen Abzentrifugieren wurde die Probe auf Eis gestellt und nach dem Erstarren aus dem Gefäß herausgelöst und mit Hilfe einer Rasierklinge in kubische Stücke von ca. $1 \mathrm{~mm}$ Kantenlänge zerteilt. Dem schlossen sich das Entwässern der in Bacto-Agar eingeschlossenen Proben (Tab. 2.6.1.) und das Einbetten in LR White mit anschließender Polymerisierung in Gelantinekapseln an.

Tabelle 2.6.1.: Das Austauschen von Wasser durch Kunstharz in den Proben

\begin{tabular}{lcc}
\hline Medium & Inkubationszeit [min] & Temperatur $\left[{ }^{\circ} \mathrm{C}\right]$ \\
Ethanol (w/v) in $\mathrm{H}_{2} \mathrm{O}_{\text {Millipore }}$ & 15 & $0{ }^{\circ} \mathrm{C}$ \\
\hline $15 \%$ Ethanol & 30 & $0{ }^{\circ} \mathrm{C}$ \\
$30 \%$ Ethanol & 30 & $-20{ }^{\circ} \mathrm{C}$ \\
$50 \%$ Ethanol & 30 & $-20{ }^{\circ} \mathrm{C}$ \\
$70 \%$ Ethanol & 30 & $-20{ }^{\circ} \mathrm{C}$ \\
$95 \%$ Ethanol & 30 & $-20{ }^{\circ} \mathrm{C}$ \\
$100 \%$ Ethanol & 30 & $-20{ }^{\circ} \mathrm{C}$ \\
$100 \%$ Ethanol & 120 oder über Nacht & $\mathrm{RT}$ oder bei $4{ }^{\circ} \mathrm{C}$ \\
$1 / 3$ Ethanol ${ }^{2}$ LR White & 120 oder über Nacht & $\mathrm{RT}$ oder bei $4{ }^{\circ} \mathrm{C}$ \\
\hline LR White & & \\
\hline
\end{tabular}

Einzelne Probenstücke wurden anschließend in mit frischem Kunstharz gefüllte Gelantinekapseln überführt. Die Proben wurden zentral in der Spitze der Kapseln 
platziert und es sollte nach deren Verschluss möglichst wenig Luft in den Kapseln verbleiben.

\subsubsection{Vorbereitung der Elektronenmikroskopie}

Nach dem Aushärten des Kunstharzes in den Kapseln wurden diese zunächst angefräst, um die eingebettete Probe freizulegen. Anschließend sind mit einem Ultramikrotom Ultradünnschnitte angefertigt worden, die i.d.R. eine Schichtdicke von $80 \mathrm{~nm}$ aufwiesen. Hierfür wurden Glasmesser verwendet, die zuvor mit einem Knifemaker aus Glasstreifen gebrochen wurden.

Als Objektträger wurden für die TEM G300 Nickel-Trägernetze (Grids) mit einem Durchmesser von 3,05 mm und quadratischen Fenstern verwendet, die zuvor mit 0,5 \% (w/v) Lösung von Formvar in wasserfreiem Chloroform beschichtet worden sind. Nachdem die Grids mit den Ultradünnschnitten beladenen worden sind, mussten die Proben kontrastiert werden. Biologische Proben enthalten i.d.R. viel Kohlenstoff, aber relativ wenig Elemente höherer Ordnungszahl. Je schwerer die Elemente sind, desto stärker sind die Wechselwirkungen der beschleunigten Elektronen und damit auch der sichtbare Kontrast. Die im Rahmen dieser Arbeit untersuchten Proben sind mit $4 \%$

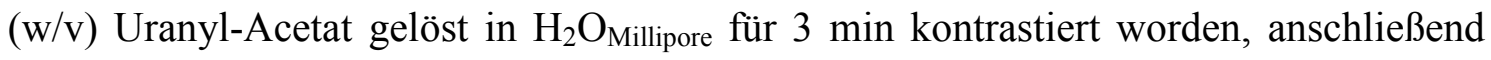
wurde überschüssige Flüssigkeit mit einem Filterpapier vorsichtig abgesaugt. Die Uranyl-Acetat-Lösung wurde zuvor für 10 min mit 13,000 upm $(17,200 \times \mathrm{g})$ bei RT abzentrifugiert, um ungelöstes Schwermetallsalz zu präzipitieren. Die Proben wurden bei einer Beschleunigungsspannung von $80 \mathrm{kV}$ mikroskopiert.

\subsubsection{Ermittlung der Quantität an ICM pro Zelle - Der Quotient ICM pro Zelle}

Um zu untersuchen, ob die Quantität an ICM in den Zellen von der Kohlenstoffquelle abhängt, wurden Zellkulturen von G. oxydans 621H in Standard-Medium (Kap. 2.2) angezogen, dem Mannitol oder Glycerol in den definierten Konzentrationen von 0,1, 0,5 und 1,0 Mol/Liter zugegeben wurde. Nach 8 h, 24 h und 48 h sind die Kulturen geerntet und für die Elektronenmikroskopie vorbereitet worden (Kap. 2.6.3). An jeweils drei unabhängig voneinander angefertigten Dünnschnitten wurden für jede Probe insgesamt ca. 1500 Zellen auf ICM-Strukturen hin untersucht. Hierbei wurde zwischen Zellen, die eine eindeutig zu identifizierende ICM aufwiesen und Zellen, in denen mögliche ICMStrukturen vorhanden waren, unterschieden. Den erstgenannten wurde der Wert 1, den 
letzteren der Wert 0,5 zugewiesen. Der auf diese Weise ermittelte Gesamtwert wurde durch die Anzahl an untersuchten Zellen geteilt. Das Ergebnis ist ein Quotient aus der Anzahl an Zellen die ICM aufwiesen und der Gesamtzahl an untersuchten Zellen [ICM/Zelle]. Der besseren Übersicht halber wurden die Ergebnisse in Prozent umgerechnet und werden in dieser Weise in Kap. 3.1.2 vorgestellt.

\subsubsection{Immunogold-Markierung von Ultradünnschnitten mit IgG-Antikörpern}

Es sind polyklonale Antikörper gegen die membrangebundene PQQ-abhängige PolyolDehydrogenase GOX0854 und die große Untereinheit der Quinol-Oxidase des bo3Typs GOX1912 hergestellt worden (2.5.5). Diese wurden für Western Blot-Analysen und zur Lokalisierung der entsprechenden Enzyme in situ mittels ImmunogoldMarkierung und anschließender TEM eingesetzt. Die Proben wurden wie in den Kapiteln 2.6.3.1 und 2.6.3.2 beschrieben vorbereitet. Nachdem die Ultradünnschnitte auf die Grids geladen wurden, sind sie allerdings zunächst mit der beladenen Seite nach unten auf PBS-Tropfen (ca. $50 \mu \mathrm{l}$ ) gelagert worden, um eine Austrocknung der Probe zu vermeiden. Dies könnte die erwünschte Wechselwirkung zwischen den Epitopen der Antigene und der entsprechenden Antikörper beeinträchtigen. Damit sich während der folgenden Weiterbehandlung der Proben die Konzentrationen innerhalb der Tropfen (ca. $50 \mu \mathrm{l})$ nicht durch Verdunsten erhöhten, wurden während der längeren Inkubationsschritte die Tropfen mit einem Deckel abgedeckt, unter dem sich zusätzlich mit Wasser getränktes Filterpapier befand. Um unspezifische Bindungsstellen an den Ultradünnschnitten zu blocken wurden die beladenen Grids zunächst auf jeweils einem Tropfen Blockierlösung für 30 min bei RT inkubiert. Im Falle des GOX0854-Strep Antikörpers betrug die Konzentration der Blockierlösung 5 \% (v/v), des GOX1912 Antikörpers $1 \%(\mathrm{v} / \mathrm{v})$, jeweils gelöst in PBS. Zwischen der Lagerung und dem Blockieren ist das an dem Grid mit dem Ultradünnschnitt verbliebene PBS mit einem Filterpapier abgesaugt worden, ein Vorgang, der im Folgenden zwischen jedem einzelnen Schritt durchgeführt wurde. Nach dem Blocken wurden die Proben für $2 \mathrm{~h}$ bei RT mit einer Lösung des primären Antikörpers mit einer Verdünnung von i.d.R. 1:1000 inkubiert, Abweichungen sind ggf. angegeben. Der GOX0854-Strep Antikörper wurde in einer 2 \%igen Blockierlösung (v/v) verdünnt, der GOX1912 Antikörper in PBS. Nach dem Ablauf der $2 \mathrm{~h}$ wurden die Proben für jeweils 5 min dreimal auf PBS-Tropfen gelegt, das $0,01 \%(\mathrm{v} / \mathrm{v})$ Tween 20 enthielt, dem sich 5 min auf einem reinen PBSTropfen anschlossen, bevor die Proben für $1 \mathrm{~h}$ auf Tropfen mit dem zweiten Antikörper 
inkubiert wurden. Dieser Antikörper ist gegen Kaninchen-Antikörper gerichtet und mit $10 \mathrm{~nm}$ großen Goldpartikeln konjugiert, die, betrachtet man die Größe von IgG Antikörpern von ca. $10 \mathrm{~nm}$ (WERNER, 1972), in einem Radius von max. $30 \mathrm{~nm}$ um das Epitop des Zielproteins zu erwarten sind. Der sekundäre Antikörper wurde jeweils im Verhältnis von 1:80 mit 2 \%iger Blockierlösung (v/v) verdünnt, der GOX1912 Antikörper in PBS.

Die Proben wurden analog zu den ersten Waschschritten behandelt, gefolgt von dem Entsalzen der Ultradünnschnitte, wobei die Proben jeweils zweimal kurz auf

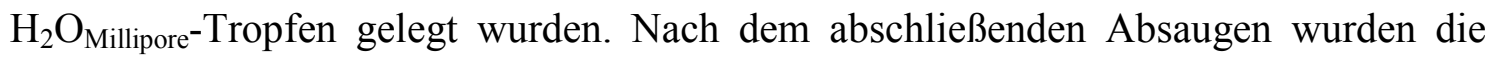
Grids mit den Ultradünnschnitten nach oben auf Filterpapier getrocknet und anschließend mit Uranyl-Acetat kontrastiert (2.6.3.2). Die Proben wurden bei einer Beschleunigungsspannung von $80 \mathrm{kV}$ mikroskopiert.

\subsubsection{Lösungen zum mikroskopischen Arbeiten}

\section{PBS}

$\mathrm{NaCl}$

$140 \mathrm{mM}$

Na-Phosphat

$10 \mathrm{mM}$

pH-Wert

$\mathrm{pH} 7,4$

\section{Blockierlösung}

Sauer hydrolysiertes Casein

Trypton

Pepton 


\section{Ergebnisse}

\subsection{Die Lokalisation membrangebundener Enzyme in G. oxydans}

Ob Proteine stark oder schwach exprimiert werden, membrangebunden oder im Cytoplasma lokalisiert sind, lässt sich mittels Immunogold-Markierung mit IgGAntikörpern an Ultradünnschnitten durch TEM untersuchen (HOPPERT, 2003; WREDE et al., 2013). Für die von G. oxydans durchgeführten unvollständigen Oxidationen sind in der Cytoplasmamembran lokalisierte Enzyme von entscheidender Bedeutung (MATSUSHITA et al., 1994). Eine Vergrößerung der Membranoberfläche durch ICM wurden in den Untersuchungen von CLAUS et al. (1975) und CLAUS und HEEFNER (1978) in G. oxydans beschrieben. Die an den unvollständigen Oxidationen beteiligten Enzyme könnten dort in erhöhter Zahl zu einem gesteigerten Umsatz an Substraten und damit zu einer erhöhten Ausbeute an wirtschaftlich interessanten Produkten führen. In den Studien von CLAUS wurde neben einer größeren Menge an ICM ein damit einhergehender erhöhter Umsatz des eingesetzten Substrates Glycerol vermutet.

Mit polyklonalen Antikörpern, gerichtet gegen die an der unvollständigen Oxidation beteiligten Enzyme sollte es möglich sein, das Potential von ICM hinsichtlich ihres Einsatzes in einer verbesserten biotechnologischen Anwendung zu untersuchen. In den sich anschließenden Kap. 3.1.1 und 3.1.2 werden Experimente und Ergebnisse während der Herstellung der Antikörper gegen die große Untereinheit der membrangebundenen PQQ-abhängigen Polyol-Dehydrogenase GOX0854 und gegen die große Untereinheit der Quinol-Oxidase des bo3-Typs GOX1912 vorgestellt. In Kap. 3.1.3 sind Immunogold-Markierungen mit den hergestellten Antikörpern von G. oxydans $621 \mathrm{H}$ sowie Deletionsmutanten als Negativkontrollen dargestellt. Die Lokalisierung der GOX0854 in Stämmen, die GOX0854/0855 ausschließlich ektopisch exprimieren schließt sich in Kap. 3.1.4 an. In Kap. 3.2.2 schließen Immunogold-Markierungen der Polyol-Dehydrogenase vergleichende Experimente des Wachstums mit Sorbitol und Glycerol ab, und in Kap. 3.3 wird der Effekt von Sauerstoffmangel im Vergleich zur Standardanzucht u. a. mittels der hergestellten Antikörper untersucht. 


\subsubsection{Die Herstellung polyklonaler Antikörper gegen die große} Untereinheit der membrangebundenen PQQ-abhängigen PolyolDehydrogenase GOX0854

Der Antikörper gegen die große Untereinheit der membrangebundenen PQQabhängigen Polyol-Dehydrogenase GOX0854 wurde wie in Kap. 2.5.5.1 beschrieben hergestellt. Die Abb. 3.1.1.a zeigt ein Coomassie gefärbtes SDS-PAGE-Gel von Rohextrakten des Stammes G. oxydans $\Delta$ upp $\Delta$ gox0854/0855 • pBBR1p264-gox0854Strep/gox0855 (Gox0854-Strep). Es vergleicht die Überexpression der PolyolDehydrogenase in Kulturen, die zu verschiedenen Zeitpunkten geerntet wurden. Die Abb. 3.1.1.b und c zeigen SDS-PAGE-Gele, wie sie im Verlauf der Aufreinigung regelmäßig zur Kontrolle der Wasch- und Elutionsschritte angefertigt wurden.
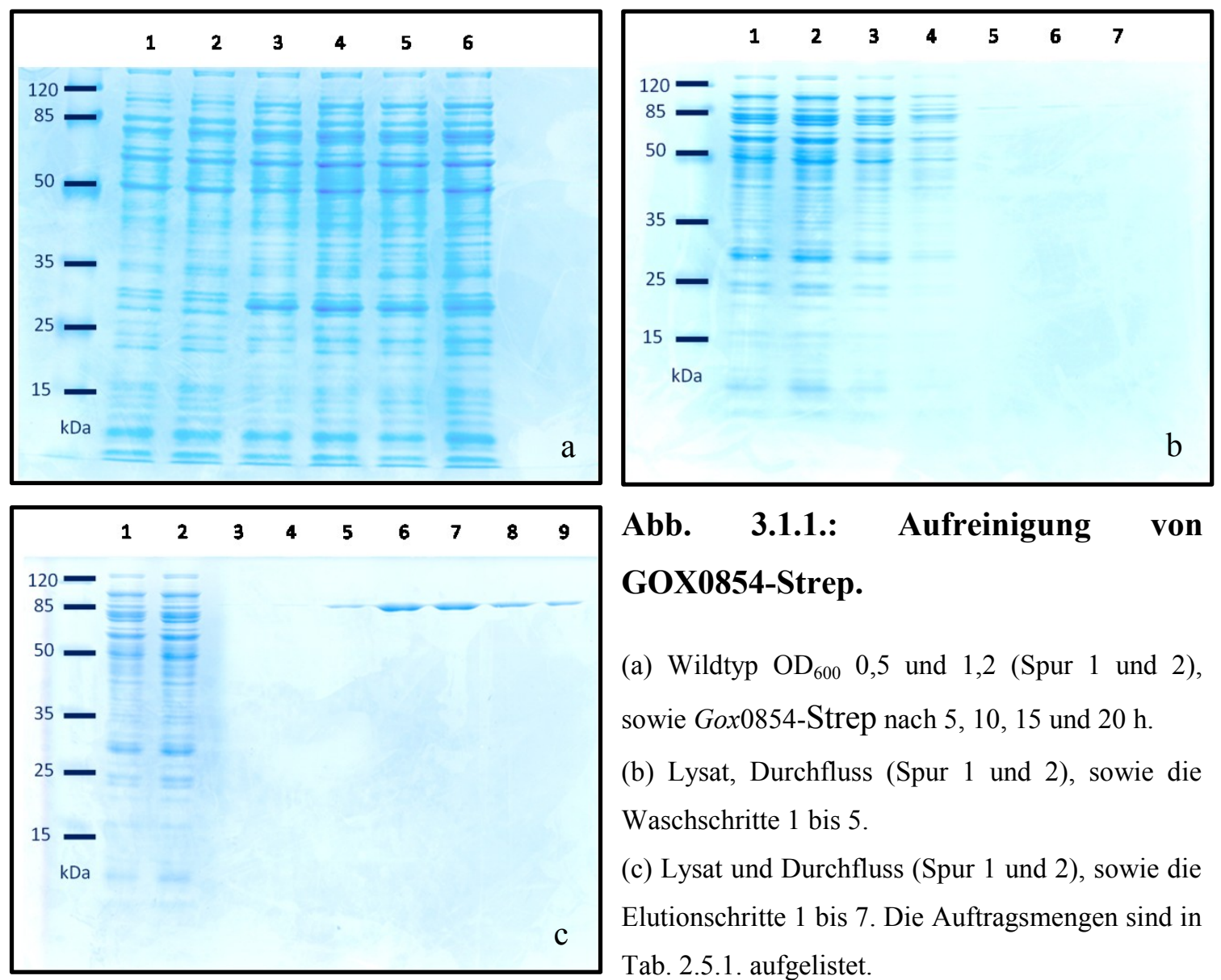

(a) Wildtyp $\mathrm{OD}_{600}$ 0,5 und 1,2 (Spur 1 und 2), sowie Gox0854-Strep nach 5, 10, 15 und 20 h.

(b) Lysat, Durchfluss (Spur 1 und 2), sowie die Waschschritte 1 bis 5 .

(c) Lysat und Durchfluss (Spur 1 und 2), sowie die Elutionschritte 1 bis 7. Die Auftragsmengen sind in Tab. 2.5.1. aufgelistet.

Die Gox0854-Strep Zellkulturen für die Aufreinigung wurden nach 15 h geerntet (Abb. 3.1.1.a, Spur 5). Auf der Höhe von $\leq 85 \mathrm{kDa}$ ist hier eine im Vergleich zum Wildtyp stärkere Bande zu erkennen (Spur 1 und 2). Das Molekulargewicht von GOX0854 
beträgt 79,5 kDa, ermittelt anhand der Primärstruktur (PRUST et al. 2005). Die Intensität dieser Bande nahm nach $20 \mathrm{~h}$ Wachstum nicht mehr zu (Spur 6). Das Waschen (Abb. 3.1.1.b) und die Elution (Abb. 3.1.1.c) des an der Säule gebundenen Proteins waren erfolgreich. Die nach der Aufreinigung erhaltenen Banden aus Spur 6 und 7 bei ca. $85 \mathrm{kDa}$ wurden ausgeschnitten und mittels Massenspektrometrie analysiert (Kap. 2.5.6). Das Analyseergebnis ist in Tabelle 3.1.1. dargestellt.

Tabelle 3.1.1.: Ergebnis der Massenspektrometrie

\begin{tabular}{lcc}
\hline & Anzahl detektierter Peptide & Anteil in Prozent \\
\hline Gesamt & 112 & 100 \\
GOX0854 & 108 & 96,43 \\
Elongationsfaktor G & 4 & 3,57 \\
\hline
\end{tabular}

Die Massenspektrometrie zeigte, dass es sich nach der hier vorgestellten Methode bei über $96 \%$ des Proteins in den ausgeschnittenen Banden der Elutionsfraktion um GOX0854 handelt. Um die erforderlichen Mengen an Antigen zu erhalten, mussten mehrere Kulturen angesetzt, geerntet und das Protein aufgereinigt werden. Die Ausbeute lag im Schnitt bei $80 \mu \mathrm{g}$ pro Liter Zellkultur, die i. d. R. eine OD $_{600}$ von 0,9 bis 1,0 hatten.

Die Antigene wurden, wie im Kapitel 2.5.5.1 beschrieben, zur Herstellung polyklonaler Antikörper eingesetzt. Der Aufbau von Antikörpern gegen die eingesetzten Antigene durch das Immunsystem der Wirtstiere wurde mittels Western Blot-Analyse (2.5.3.3.) verfolgt. Die Abbildung 3.1.2. zeigt die Western Blot-Analyse des Prä-Immunserum (a) im Vergleich mit dem im Rahmen dieser Arbeit eingesetzten Serums der kleinen Blutung nach $38 \mathrm{~d}(\mathrm{~b})$. 

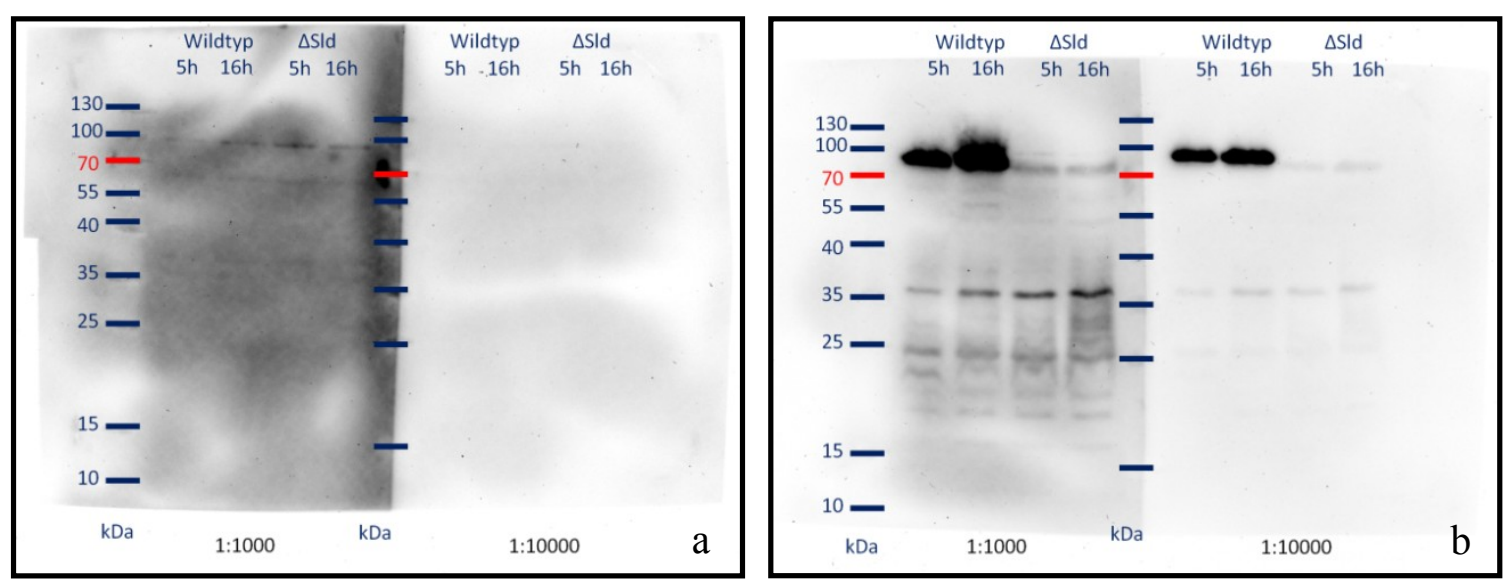

Abb. 3.1.2.: Western Blot-Analysen Prä-Immunserum und kleine Blutung.

Die Seren wurden jeweils einmal in den Verdünnungen 1:1000 und 1:10000 eingesetzt. Es wurden Rohextrakte aus der exponentiellen $(5 \mathrm{~h})$ und stationären (16 h) Wachstumsphase vom Wildtyp G. oxydans $612 \mathrm{H}$ und der Deletionsmutante G. oxydans $621 \mathrm{H} \Delta$ upp $\Delta$ gox0854/0855 verglichen. Mw von GOX0854: 79,6 kDa.

Das Prä-Immunserum zeigte einen vernachlässigbar geringen Hintergrund (Abb. 3.1.2.a). Nach $38 \mathrm{~d}$ und drei Injektionen ist im Falle des Wildtyps eine starke Bande zwischen 70 und $100 \mathrm{kDa}$ zu sehen (b), die im Rohextrakt der Deletionsmutante \upp $\Delta$ gox0854/0855 fehlt. Anhand der Primärstruktur beträgt das Mw von GOX0854 79,5 kDa (PRUST et al. 2005).

\subsubsection{Der Antikörper gegen die große Untereinheit der Quinol- Oxidase des bo3-Typs GOX1912}

Der Antikörper gegen die große Untereinheit der Quinol-Oxidase des bo3-Typs GOX1912 wurde wie unter Punkt 2.5.5.2 beschrieben hergestellt. Die Polypeptide, die als Antigene eingesetzt wurden, sind anhand der Primärstruktur von der Fa. Eurogentec vorgeschlagen und synthetisiert worden. Die Aminosäuresequenzen der Polypeptide sind in der Tabelle 3.1.2. aufgeführt.

\section{Tabelle 3.1.2.: Die Antigene zur Herstellung der Antikörper gegen GOX1912}

\section{Peptid 1 IRDRNLPENLDLTGDP}

Peptid 2 EGMTRRMNHYDNPDWY

Der Aufbau von Antikörpern gegen die eingesetzten Antigene durch das Immunsystem der Wirtstiere wurde mittels Western Blot-Analyse (Kap. 2.5.3.3) verfolgt. Die 
Abb. 3.1.3. zeigt die Western Blot-Analyse des im Rahmen dieser Arbeit eingesetzten Serums im Vergleich mit dem Prä-Immunserum. Das eingesetzte Serum entsprach der finalen Blutung nach $87 \mathrm{~d}$, das zusätzlich von der Fa. Eurogentec mittels der synthetisierten Antigene aufgereinigt wurde. Das Molekulargewicht von GOX1912 beträgt $74 \mathrm{kDa}$, ermittelt anhand der Primärstruktur (PRUST et al. 2005).

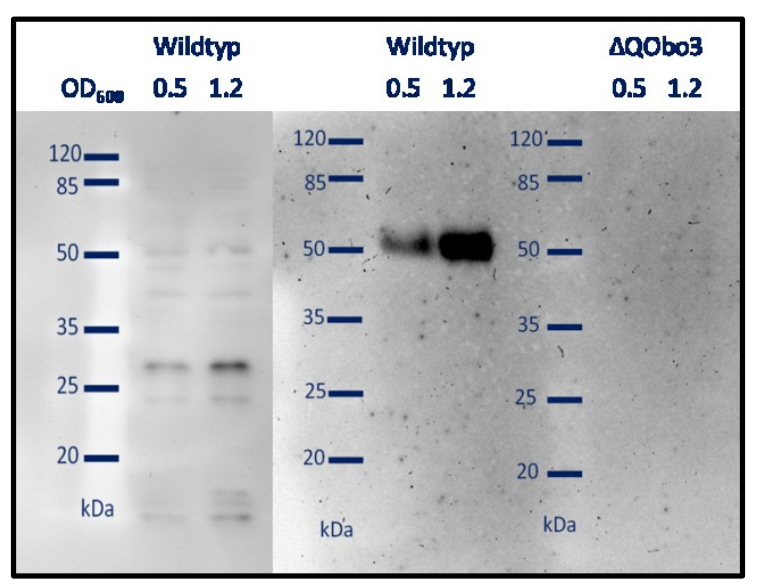

\begin{abstract}
Abb. 3.1.3.: Western Blot-Analysen Prä-Immunserum und aufgereinigtes Serum.

Die Seren wurden in 1000-facher Verdünnung eingesetzt. Links: Prä-Immunserum getestet mit Rohextrakten des Wildtyp. Rechts: Aufgereinigtes Serum getestet mit Rohextrakten des Wildtyp und der Deletionsmutante G. oxydans $\Delta$ upp $\Delta$ gox1911-1914. Mw von GOX1912: $74 \mathrm{kDa}$.
\end{abstract}

Das Prä-Immunserum zeigte einen schwachen Hintergrund, insbesondere im Bereich zwischen 25 und $35 \mathrm{kDa}$. Nach $87 \mathrm{~d}$, vier Injektionen und der Aufreinigung des Antikörpers ist im Falle des Rohextraktes des Wildtyps eine Bande $\geq 50 \mathrm{kDa}$ zu sehen, die im Rohextrakt der Deletionsmutante Aupp Agox1911-1914 fehlt.

\title{
3.1.3 Elektronenmikroskopische Untersuchung des Immunogold- markierten Wildtyps G. oxydans $621 \mathrm{H}$ und Immunogold-markierter Deletionsmutanten
}

Die für das Immunogold-Markieren ausgewählten Antikörperseren wurden an Proben des Wildtyps G. oxydans $621 \mathrm{H}$ und den jeweiligen Deletionsmutanten G. oxydans $\Delta$ upp $\Delta$ gox0854/0855 und $\Delta$ upp $\Delta$ gox1911-1914 getestet. 
3.1.3.1 Die Lokalisierung der großen Untereinheit der membrangebundenen PQQ-abhängigen Polyol-Dehydrogenase GOX0854 an Proben des Wildtyps und der Deletionsmutante

Zellen von $G$. oxydans $621 \mathrm{H}$ und der Deletionsmutante $G$. oxydans $\Delta$ upp $\Delta$ gox0854/0855 wurden, wie in Kapitel 2.6.3 beschrieben, für die Transmissionselektronenmikroskopie (TEM) vorbereitet, anschließend mit dem Antikörper gegen die GOX0854 Immunogold-markiert und mikroskopiert. Elektronenmikrographien von Zellen des Wildtyps und der Deletionsmutante sind in den Abbildungen 3.1.4. und 3.1.5. zu sehen.
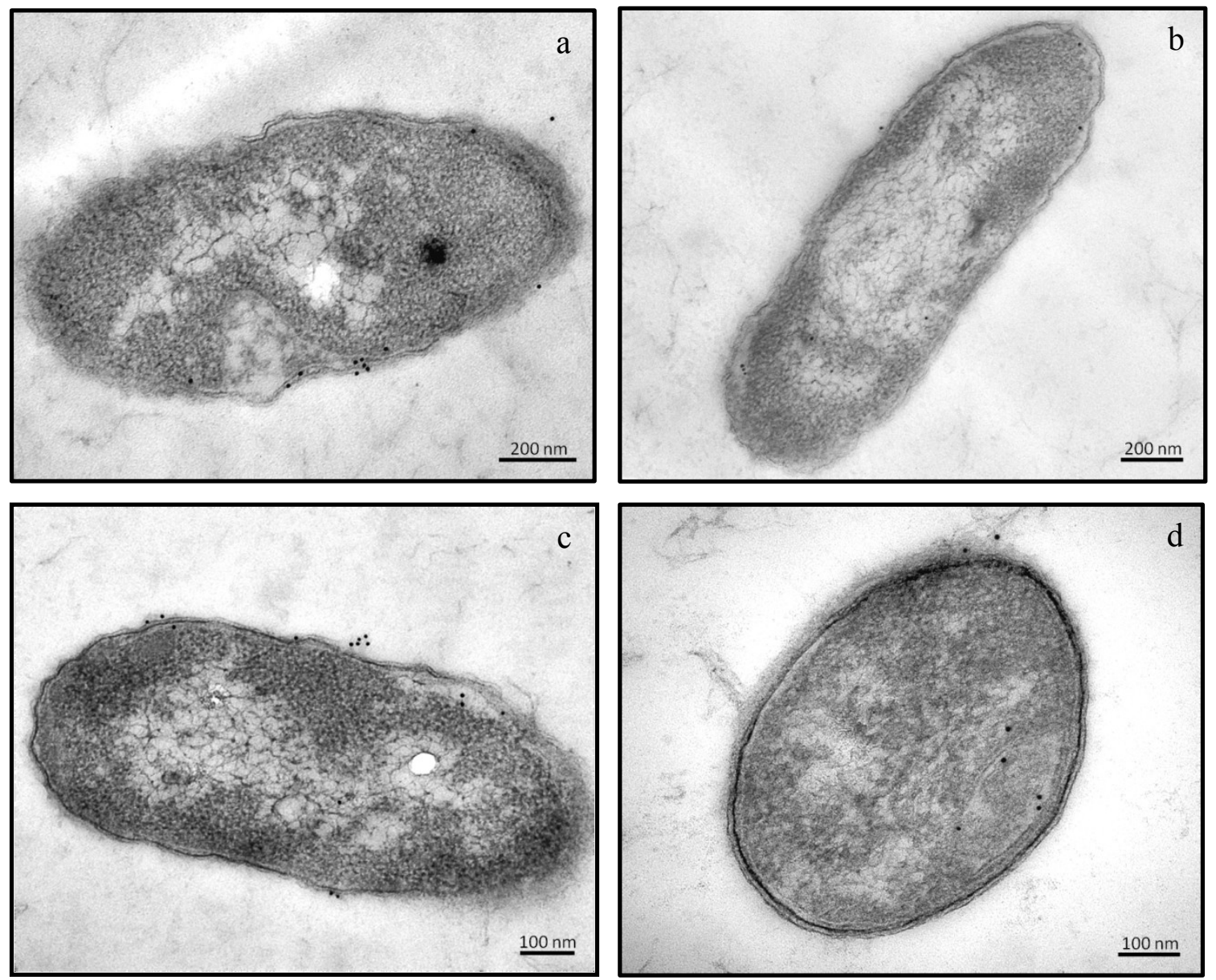

\section{Abbildung 3.1.4.: Wildtyp $G$. oxydans $621 \mathrm{H}$ mit Immunogold-markierter GOX0854.}

Die Abb. zeigt TEM-Elektronenmikrograhien von G. oxydans 621H, die mit dem Antikörper gegen die große Untereinheit der membranständigen Polyol-Dehydrogenase GOX0854 markiert wurden. Die in Kunstharz eingebetteten Zellkulturen wurden zuvor in Standard Mannitol-Medium (a und b), bzw. in Standard Glycerol-Medium (c und d) angezogen. Auf den linken Abb. sind Zellen nach $8 \mathrm{~h}$ Wachstum gezeigt (a, c) und auf den rechten Abb. Zellen nach $24 \mathrm{~h}$ Wachstum (b, d). 

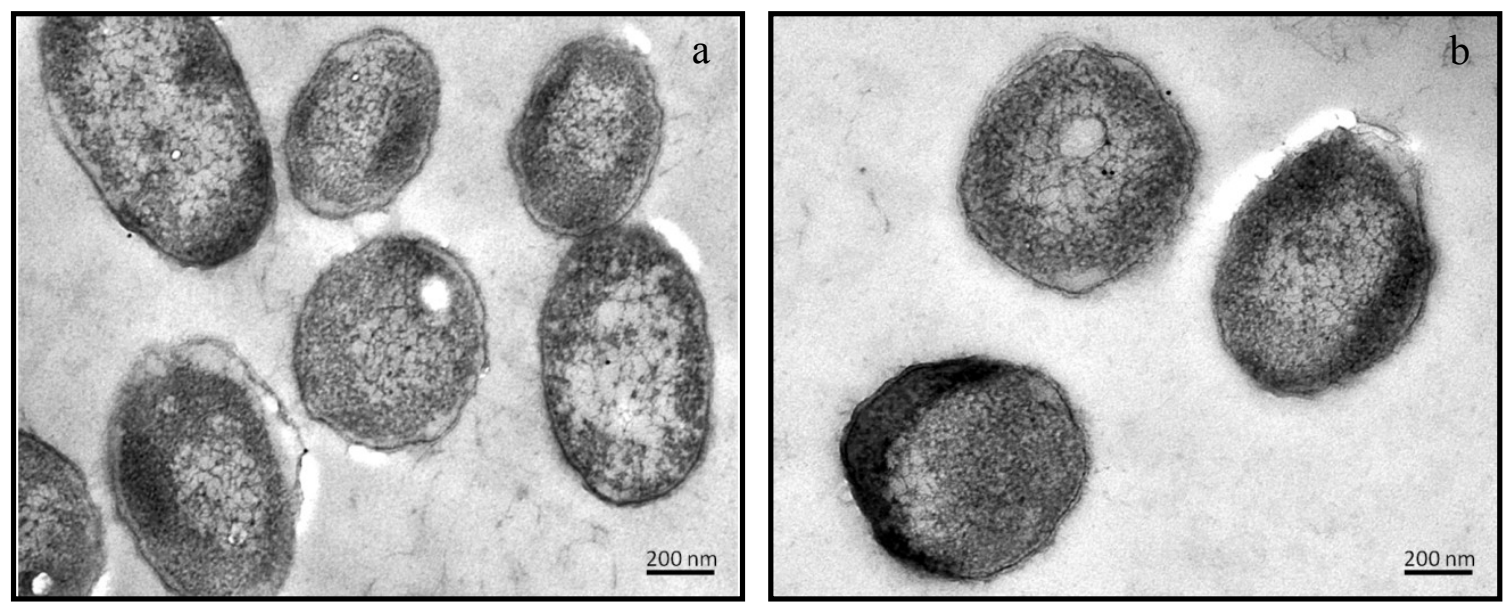

Abbildung 3.1.5.: Deletionsmutante G. oxydans Aupp Agox0854/0855.

Die Abbildung 3.1.5. zeigt TEM-Elektronenmikrograhien von G. oxydans 621H 4upp 4gox0854/0855, die mit dem Antikörper gegen die große Untereinheit der membranständigen Polyol-Dehydrogenase GOX0854 markiert wurden. Die in Kunstharz eingebetteten Zellkulturen wurden zuvor in KomplexMedium mit $50 \mathrm{mM}$ Fructose (2.2.3) für $8 \mathrm{~h}$ (a) bzw. $24 \mathrm{~h}$ (b) angezogen.

Die Immunogold-Markierung zeigt im Falle des Wildtyps (Abb. 3.1.4.), dass GOX0854 überwiegend im Bereich der Zellperipherie lokalisiert werden konnte. In den Zellen die mit Standard Mannitol-Medium (a und b) oder mit Standard Glycerol-Medium (c und d) angezogen wurden ist die Intensität der Markierungen ähnlich. Nach $8 \mathrm{~h}$ Wachstum (links, a und c) ist die Intensität der Markierung etwas stärker als nach 24 h (rechts, $\mathrm{b}$ und d). In der Abb. 3.1.4.a ist eine unmarkierte, in Abb. 3.1.4.d ist eine markierte ICM zu erkennen. Für die Deletionsmutante (Abb. 3.1.5.) muss man eine schwache, primär zellperiphere Markierung konstatieren, deren Intensitäten nach 8 h (a), bzw. 24 h (b) ähnlich sind.

\subsubsection{Die Lokalisierung der großen Untereinheit der Quinol-Oxidase des bo3-} Typs GOX1912 an Proben des Wildtyps und der Deletionsmutante

Zellen des Wildtyps G. oxydans $621 \mathrm{H}$ und der Deletionsmutante G. oxydans $621 \mathrm{H}$ Аupp Agox1911-1914 wurden wie in Kapitel 2.6.3 beschrieben für die TEM vorbereitet, mit dem Antikörper gegen GOX1912 Immunogold-markiert und mikroskopiert. Elektronenmikrographien von Zellen des Wildtyps und der Deletionsmutante sind in den Abbildungen 3.1.6. und 3.1.7. zu sehen. 

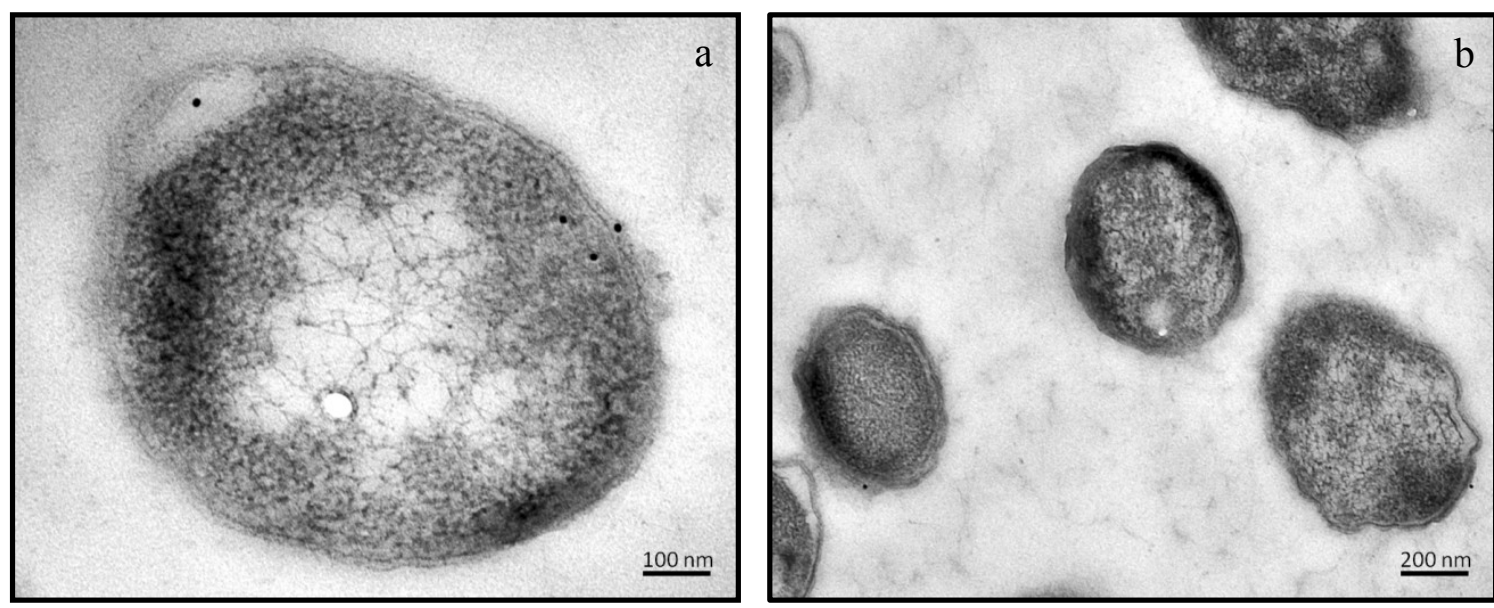

\section{Abbildung 3.1.6.: Wildtyp $G$. oxydans 621H mit Immunogold-markierter GOX1912.}

Die Abbildungen 3.1.6.a und b zeigen TEM-Elektronenmikrograhien von G. oxydans 621H, markiert mit dem Antikörper gegen die Quinol-Oxidase des bo3-Typs GOX1912. Die in Kunstharz eingebetteten Zellkulturen wurden zuvor in Glycerol-Medium (Kap. 2.2.2) für 8h (a) bzw. 24 h (b) angezogen.
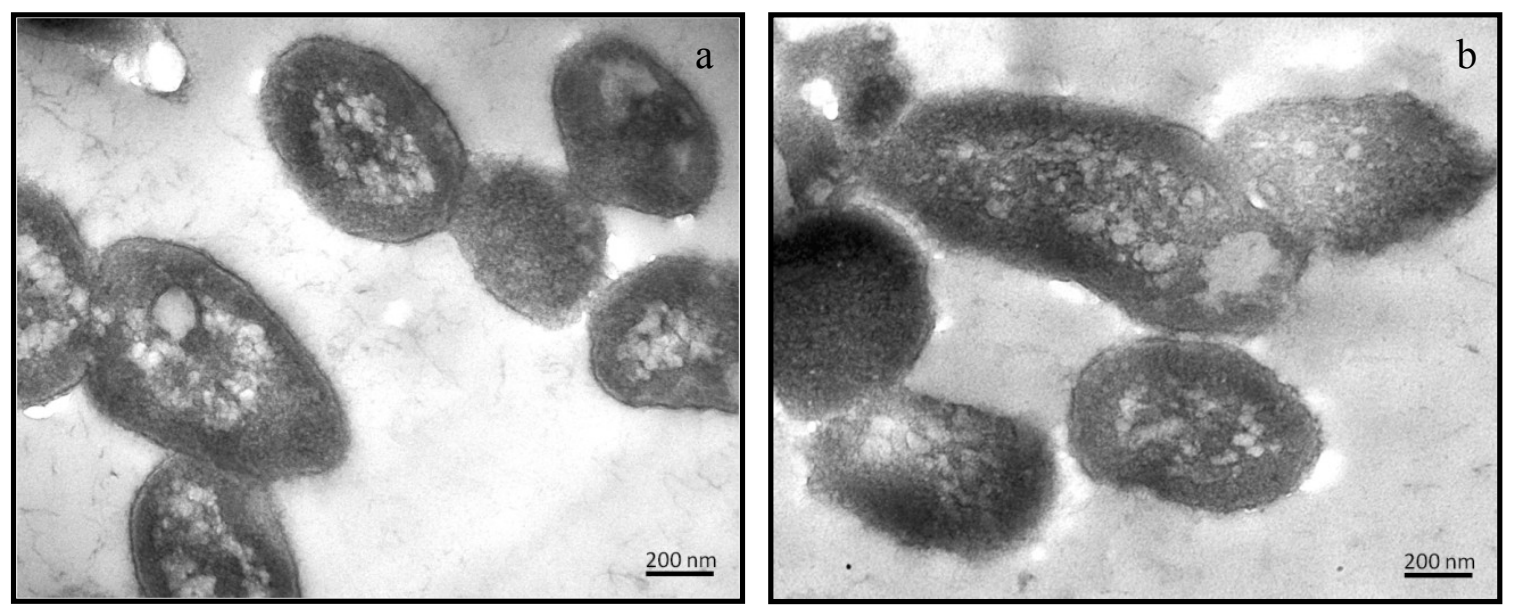

Abbildung 3.1.7.: Deletionsmutante G. oxydans Aupp Agox1911-1914.

Die Abb. 3.1.7.a und b zeigen TEM-Elektronenmikrograhien von G. oxydans Aupp Agox1911-1914, markiert mit dem Antikörper gegen die Quinol-Oxidase des bo3-Typs GOX1912. Die in Kunstharz eingebetteten Zellkulturen wurden in Glycerol-Medium (Kap. 2.2.2) für 12 h (a) bzw. 24 h (b) angezogen.

GOX1912 ist in den Zellen des Wildtyps schwach und überwiegend in der Zellperipherie lokalisiert worden (Abb. 3.1.6.), wobei die Markierung in Zellen nach $8 \mathrm{~h}$ Wachstum (a) etwas stärker ist, als nach 24 h Wachstum (b). Die Deletionsmutante wies nur eine äußerst schwache Markierung in beiden untersuchten Wachstumsphasen auf. 


\subsubsection{Die Lokalisierung der großen Untereinheit der membran- gebundenen PQQ-abhängigen Polyol-Dehydrogenase GOX0854 in Stämmen, die GOX0854/0855 ausschließlich ektopisch exprimieren}

Von Kooperationspartnern wurden dieser Arbeit Stamm-Derivate von G. oxydans $621 \mathrm{H}$ zur Verfügung gestellt, denen das Gen für GOX0854/0855 deletiert wurde, und die anschließend mit verschiedenen Plasmiden zur Komplementierung der Deletion transformiert worden sind (Kap. 2.1). Die Plasmide unterscheiden sich durch die Promotorregionen, die vor das Gen für GOX0854/0855 kloniert wurden. Zum einen handelt es sich um den Stamm G. oxydans $\Delta$ upp $\Delta$ gox0854/0855 • pBBR1p264gox0854-Strep/gox0855, der im Folgenden als Gox0854-Strep bezeichnet wird, und der u. a. für die Herstellung des Antikörpers gegen GOX0854 genutzt worden ist. Zum anderen sind es die Stämme G. oxydans $\Delta$ upp $49 x 2$ ·pBBR1pQIDH-gox0854/gox0855, kurz Gox-pQIDH-GOX0854/0855 und G. oxydans $\Delta$ upp $49 x 2$ ' pBBR1pADHgox0854/gox0855, kurz Gox-pADH-GOX0854/0855. Alle drei komplementierten Deletionsmutanten wurden wie in Kapitel 2.6.3 beschrieben für die Transmissionselektronenmikroskopie (TEM) vorbereitet, mit dem Antikörper gegen GOX0854 Immunogold-markiert und mikroskopiert. Elektronenmikrographien von Zellen der komplementierten Deletionsmutanten sind in den Abbildungen 3.1.8. bis 3.1.11. zu sehen.
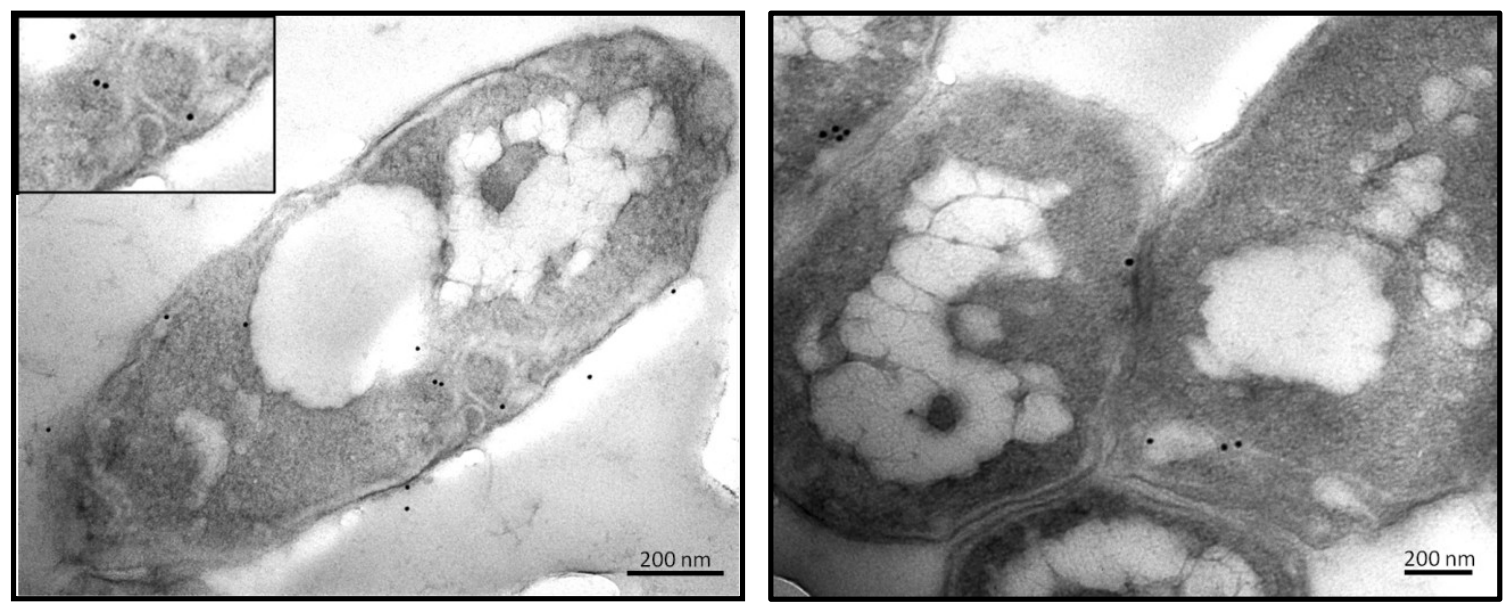

Abbildung 3.1.8.: Gox0854-Strep mit Immunogold-markierter GOX0854.

Die Abb. zeigt TEM-Elektronenmikrograhien von Gox0854-Strep, markiert mit dem Antikörper gegen die große Untereinheit der membranständigen Polyoldehydrogenase GOX0854. Die in Kunstharz eingebetteten Zellkulturen wurden zuvor in Glycerol-Medium (2.2.2) für $8 \mathrm{~h}$ angezogen. 
Der Stamm Gox0854-STREP exprimiert GOX0854 mit einem Strep-Tag. In der Abb. 3.1.8. zeigt dieser Stamm eine im Vergleich zum Wildtyp (Abb. 3.1.4.) schwächere, im Vergleich zur Deletionsmutante (Abb. 3.1.5.) stärkere Markierung, vorwiegend an den Membranen. Die hier sichtbaren ICM sind ebenfalls markiert und dies u. a. auch vergrößert dargestellt.

Der Stamm Gox-pQIDH-GOX0854/0855 exprimiert die Polyol-Dehydrogenase unter dem Einfluss des Promotors der Inositol-Dehydrogenase GOX1857 (HÖLSCHER et al., 2007), auf dessen Induzierbarkeit bisher unveröffentlichte Daten der AG Ehrenreich, TU München, hindeuten. Es wurden, je nachdem, ob Mannitol oder Sorbitol als Substrat für die Anzucht eingesetzt wurde, unterschiedliche Aktivität des Promotors für GOX1857 und damit eine evtl. variierende Expression der Polyol-Dehydrogenase erwartet. Im Folgenden sind Immunogold-markierte Zellen des Stammes Gox-pQIDHGOX0854/0855 zu sehen, die zum einen mit Mannitol (Abb. 3.1.9.) und zum anderen mit Sorbitol (Abb. 3.1.10.) angezogen worden sind.
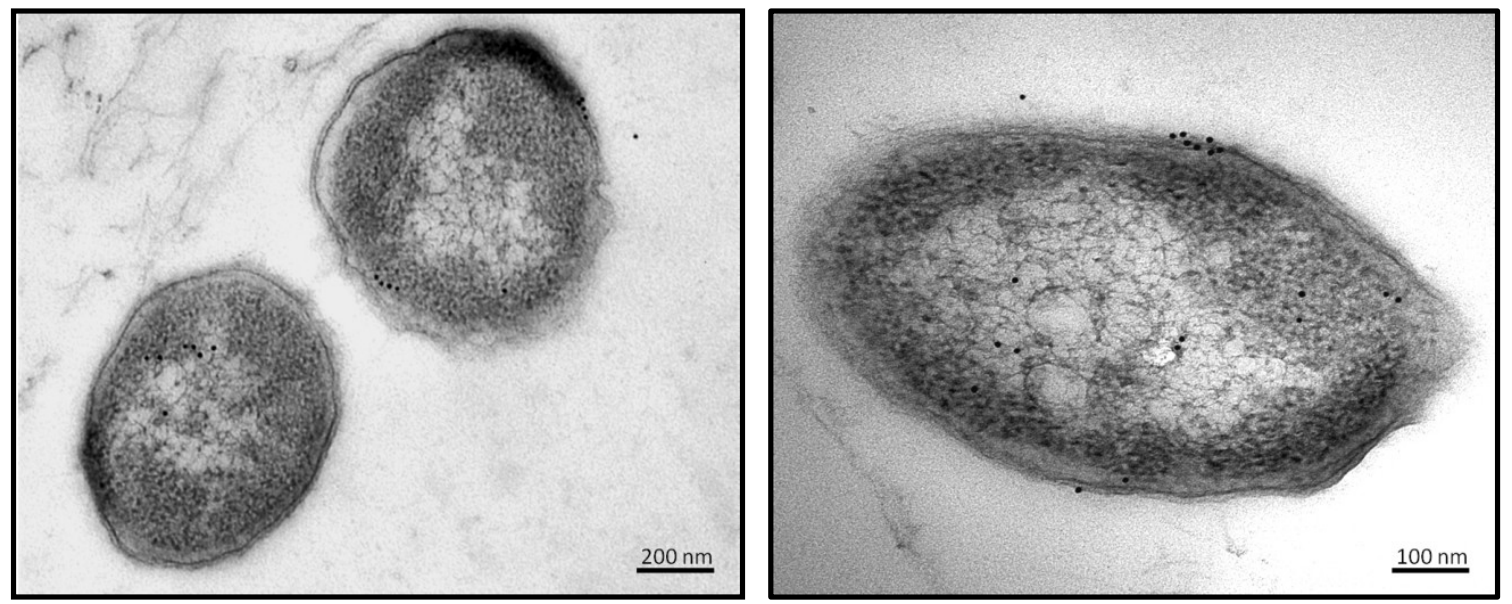

Abbildung 3.1.9.: Gox-pQIDH-GOX0854/0855, auf Mannitol angezogen mit Immunogold-markierter GOX0854.

Die Abbildung 3.1.9. zeigt TEM-Elektronenmikrograhien von Gox-pQIDH-GOX0854/0855, markiert mit dem Antikörper gegen die große Untereinheit der membranständigen Polyoldehydrogenase GOX0854. Die in Kunstharz eingebetteten Zellkulturen wurden zuvor in Komplex-Medium mit 50 mM Mannitol (2.2.3) für $8 \mathrm{~h}$ angezogen. 

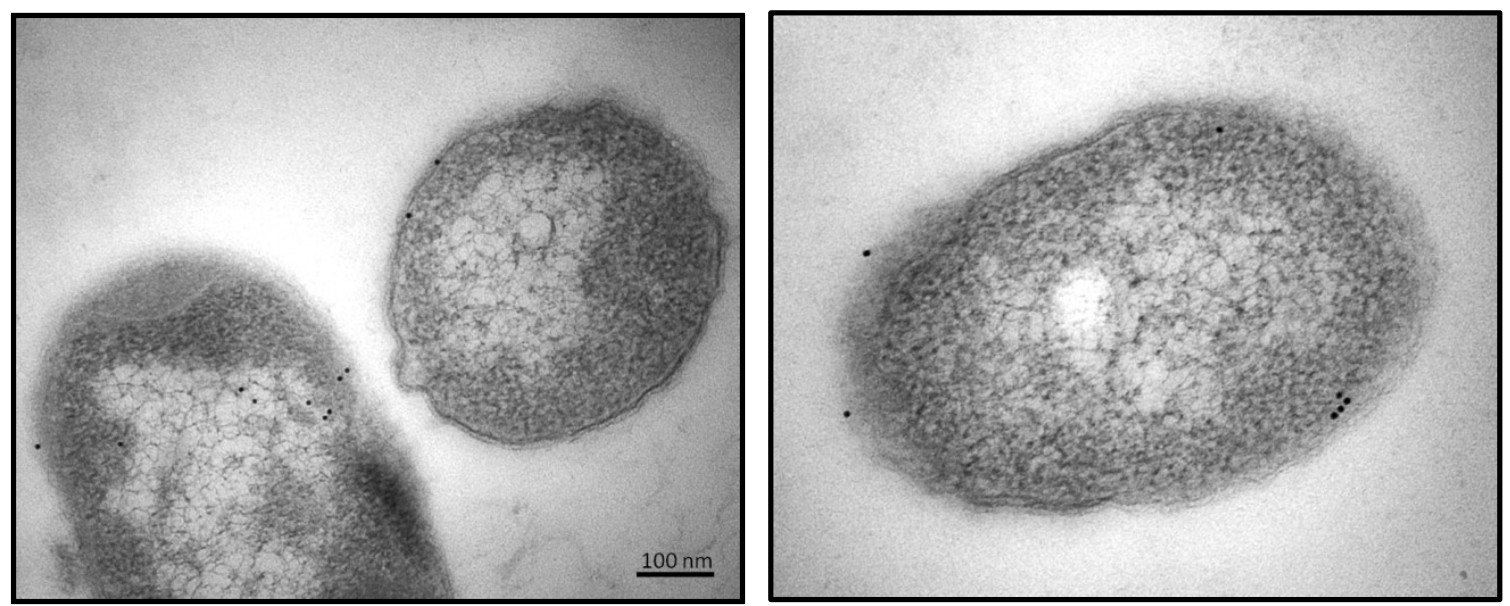

Abbildung 3.1.10.: Gox-pQIDH-GOX0854/0855, auf Sorbitol angezogen mit

\section{Immunogold-markierter GOX0854.}

Die Abb. 3.1.10. zeigt TEM-Elektronenmikrograhien von Gox-pQIDH-GOX0854/0855, markiert mit dem Antikörper gegen die große Untereinheit der membranständigen Polyoldehydrogenase GOX0854. Die in Kunstharz eingebetteten Zellkulturen wurden zuvor in Komplex-Medium mit $50 \mathrm{mM}$ Sorbitol (2.2.3) für $8 \mathrm{~h}$ angezogen.

Aus den Abb. 3.1.9. und 3.1.10. geht hervor, dass mittels der Immunogold-Markierung von GOX0854 kein signifikanter Unterschied in der Expression der Polyoldehydrogenase zwischen dem Wachstum auf Mannitol oder Sorbitol festzustellen ist. Für diesen Stamm fällt neben markierten peripheren Bereichen der Zellen eine stärkere Markierung des Cytoplasmas auf, die in den zuvor vorgestellten Markierungsexperimenten so nicht zu beobachten war.
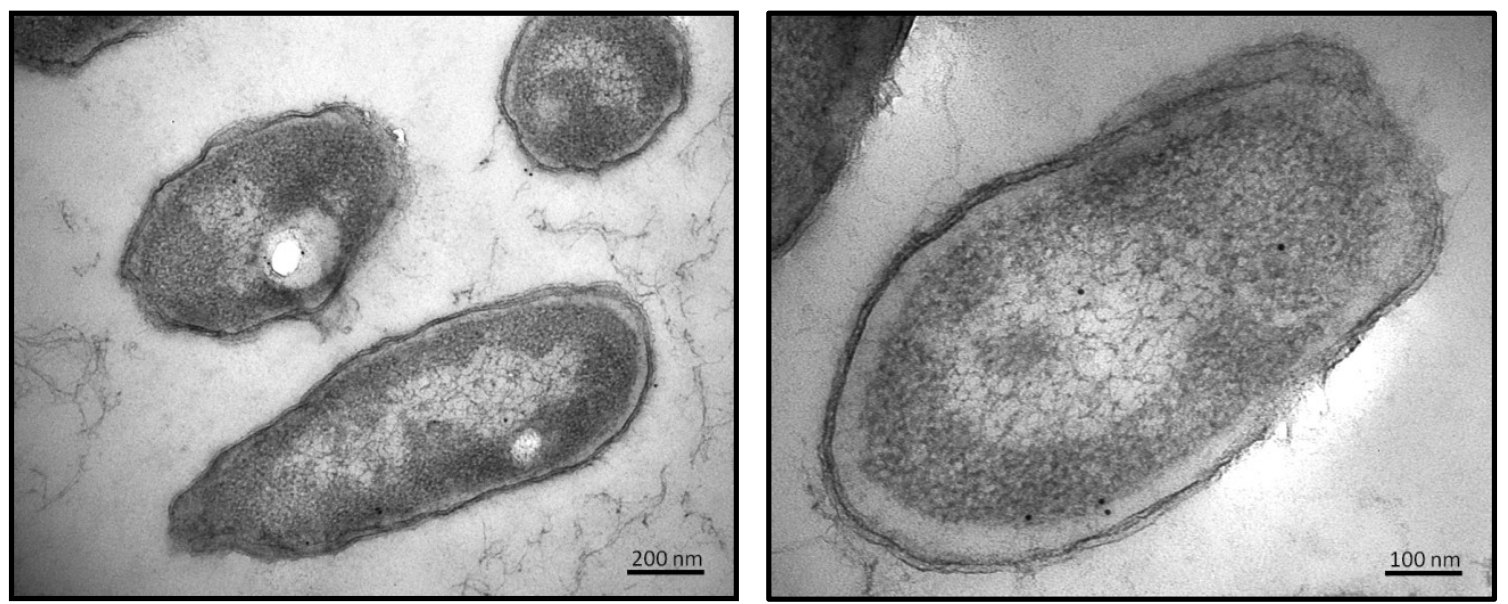

Abbildung 3.1.11.: Gox-pADH-GOX0854/0855, auf Mannitol angezogen mit Immunogold-markierter GOX0854.

Die Abb. 3.1.11. zeigt TEM-Elektronenmikrograhien von Gox-pADH-GOX0854/0855, markiert mit dem Antikörper gegen die große Untereinheit der membranständigen Polyoldehydrogenase GOX0854. Die eingebetteten Zellkulturen wurden in Komplex-Medium mit 50 mM Mannitol (2.2.3) für $8 \mathrm{~h}$ angezogen. 
Die Abb. 3.1.11. zeigt Zellen des Stammes Gox-pADH-GOX0854/0855, bei dem die Expression der membranständigen Polyol-Dehydrogenase unter der Kontrolle des Promotors für die Alkohohl-Dehydrogenase GOX1067/1068 steht. Die Markierung von GOX0854 ist hier schwächer als beim Wildtyp, evtl. zeigte sie die schwächste detekierbare Expression von GOX0854, und ist nicht auf den peripheren Bereich der Zellen beschränkt (Abb. 3.1.11.).

\subsection{Die Untersuchung der Entwicklung und des Vorkommens intracytoplasmatischer Membranen in G. oxydans 621H}

In den Arbeiten von CLAUS et al. (1975) sowie HEEFNER und CLAUS (1978) wurde eine erhöhte Menge an intracytoplasmatischen Membranen (ICM) in Zellen von G. oxydans aus der stationären Wachstumsphase festgestellt. Die mit dem Auftreten der ICM einhergehende erhöhte Respirationsrate wurde einem gesteigerten Umsatz des eingesetzten Substrates Glycerol zugeschrieben. Ziel dieser Arbeit war es u. a. zu ergründen, ob dieser Effekt für die biotechnologische Anwendung von Nutzen sein könnte. Je größer die Oberfläche der Cytoplasmamembran ist, desto mehr enzymatische Systeme zur unvollständigen Oxidation könnten in ihr Platz finden und zu einem höheren Umsatz von Substraten zu wirtschaftlich interessanten Produkten führen.

Zunächst wurden Zellen von $G$. oxydans $621 \mathrm{H}$ mittels Transmissionselektronenmikroskopie (TEM) auf ICM hin untersucht. Die dabei gemachten Beobachtungen sind $\mathrm{u}$. a. in Kap. 3.2.1 zu einer möglichen Darstellung der Differenzierung der Cytoplasmamembran hin zu ICM zusammengefasst. In Kap. 3.2.2 wird der Frage nachgegangen, ob ein gehäuftes Auftreten an ICM oder ICM-ähnlichen Strukturen in G. oxydans $621 \mathrm{H}$ in einem gestörten Wachstum in Folge des Alters einer Kultur bzw. einer Anhäufung cytotoxischer Substanzen begründet sein könnte. SATTLER (1964) sowie OHREM und VOSS (1996) beschrieben ein gestörtes Wachstum von G. oxydans, hervorgerufen durch das im Verlauf der Verwertung des Glycerols auftretende Dihydroxyaceton.

\subsubsection{Differenzierung der Cytoplasmamembran}

Die Bildung von ICM setzt eine Differenzierung der Cytoplasmamembran voraus. Die Erweiterung der Membranoberfläche ist entweder die Folge, oder die Voraussetzung für 
die Integration membranständiger Proteine. Letztendlich sind sie Invaginationen der Cytoplasmamembran, oder aus ihr hervorgegangen (OELZE und DREWS, 1971). Die Abb. 3.2.1. bis 3.2.3. zeigen TEM-Mikrographien von Zellen aus einer Kultur von G. oxydans $621 \mathrm{H}$, die unter Standardbedingungen (Kap. 2.3) und in Standard MannitolMedium (Kap. 2.2.1) über $24 \mathrm{~h}$ angezogen wurde. $\mathrm{Zu}$ sehen sind Zellen die ICM enthalten, sortiert in einer Reihenfolge, die eine fortschreitende Entwicklung darstellen könnte.
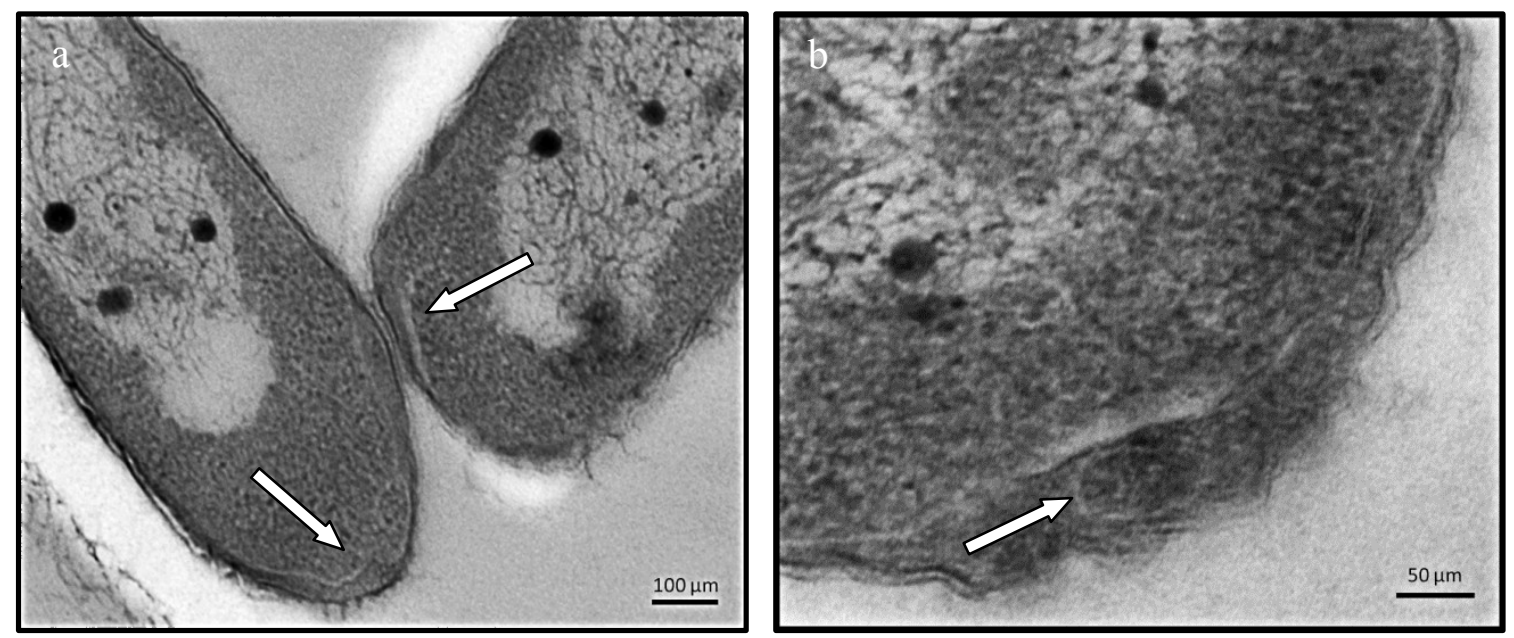

Abb. 3.2.1.: G. oxydans 621H mit ICM.

(a) Zellen von G. oxydans 621H, an den Zellpolen sind ICM zu sehen (Pfeile). (b) Die dargestellte ICM scheint einen Bereich des Cytoplasmas am Zellpol zu umschließen (Pfeil).

In der Abb. 3.2.1. sind an den Zellpolen ICM zu erkennen (Pfeile). In stäbchenförmigen Bakterien befinden sich dort viele Ribosomen, und damit eine hohe Biosynteseaktivität (MASCARENHAS et al., 2001). In Abb. 3.2.1.b sind eine beginnende Invagination der Cytoplasmamembran und eine Kompartimentierung des Cytoplasmas zu erkennen (Pfeil). 

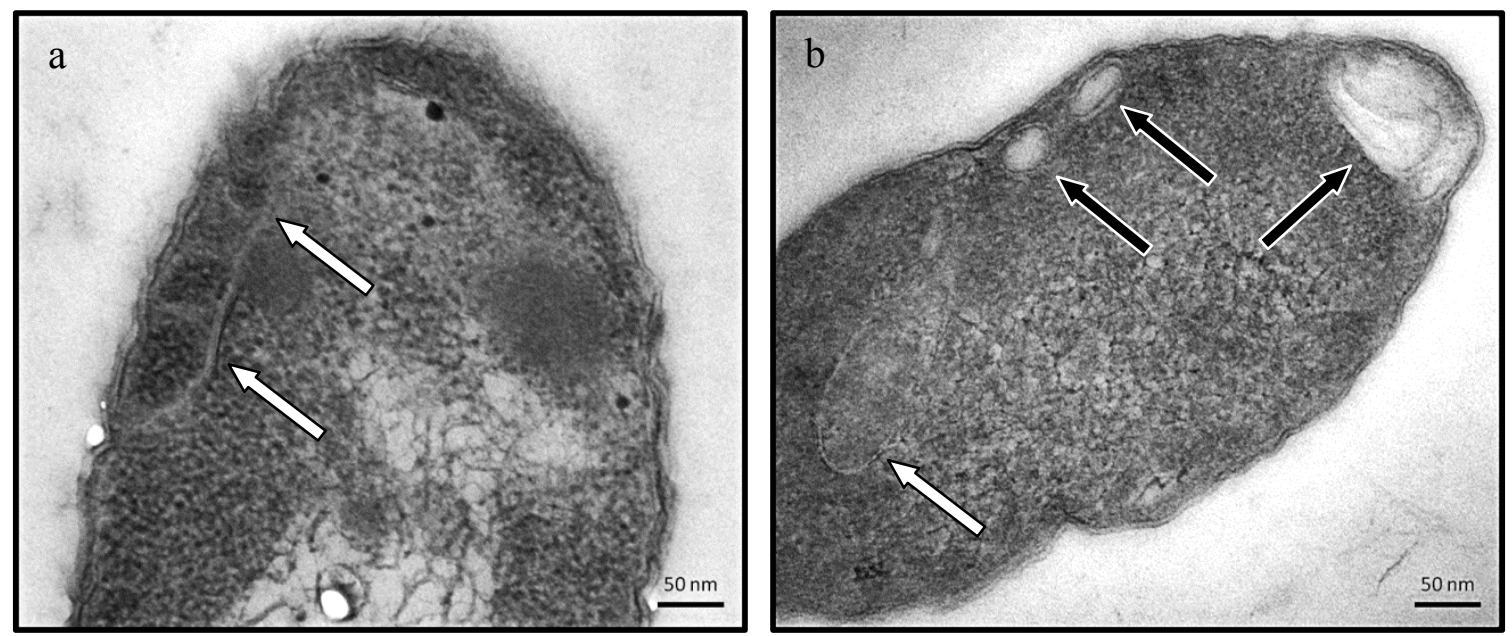

Abb. 3.2.2.: ICM kompartimentieren Bereiche des Cytoplasmas.

G. oxydans-Zellen, deren ICMs einen Bereich des Cytoplasmas kompartimentieren (a und b, weiße Pfeile). (b) ICMs umgeben ein Lumen ohne Ribosomen (schwarze Pfeile).

Der beschriebene Einschluss von Bereichen des Cytoplasmas setzt sich in den Zellen fort, die in der Abb. 3.2.2. dargestellt sind. Die Abb. 3.2.2.b zeigt eine Zelle, in der die ICM neben den bereits vorgestellten Strukturen (weiße Pfeile) bereits ein Lumen umgeben, das keine Ribosomen enthält und mit dem Periplasma in Kontakt stehen könnte (schwarze Pfeile). Die meisten bisher gezeigten Strukturen waren überwiegend an der Zellperipherie lokalisiert. Im Gegensatz dazu sind die von Membranen umschlossenen Lumina der Zellen in der Abb. 3.2.3. nicht auf den Bereich nahe der Cytoplasmamembran beschränkt und relativ groß.
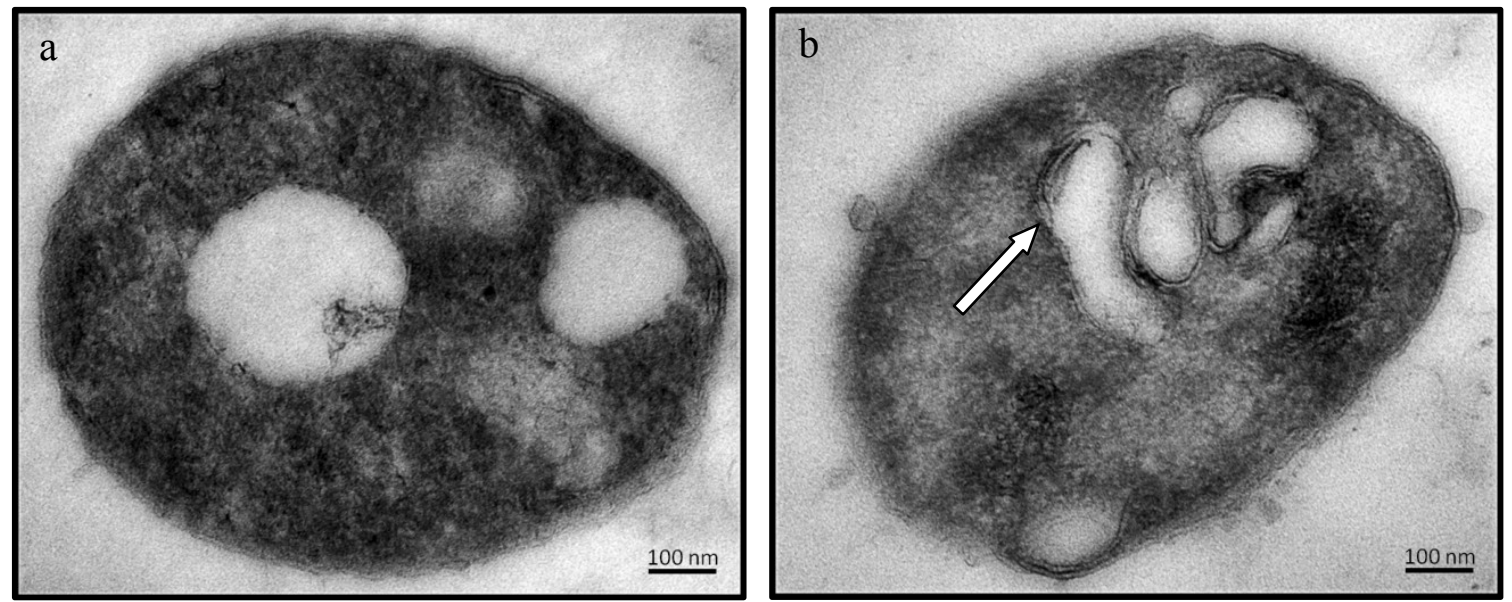

Abb. 3.2.3.: ICMs bilden größere, zentrale Lumina.

Dargestellt sind relativ große (a) und Eindeutig durch ICM umschlossene Lumina (b, Pfeil) von $G$. oxydans-Zellen. 


\subsubsection{Untersuchung des Einflusses von Glycerol und Mannitol auf die Quantität von ICM in Abhängigkeit der Wachstumsphasen}

Ein Grund für ein gehäuftes Auftreten an ICM oder ICM-ähnlichen Strukturen in G. oxydans $621 \mathrm{H}$ könnte ein gestörtes Wachstum in Folge des Alters einer Kultur bzw. einer Anhäufung wachstumshemmender Substanzen sein, wie es für das im Verlauf der Verwertung des Glycerol auftretende Dihydroxyaceton beschrieben wurde (SATTLER, 1964, OHREM und VOSS, 1996). Um dies zu untersuchen wurden Zellkulturen von G. oxydans $621 \mathrm{H}$ in Standard-Medium angezogen, dem jeweils Glycerol oder Mannitol als Substrat in den definierten Konzentrationen von 0,1, 0,5 und 1,0 Mol/Liter zugegeben wurde. Die Anzucht erfolgte bei $30^{\circ} \mathrm{C}$ und 200 upm. Nach der Aufnahme von Wachstumskurven, der Berechnung von max. Wachstumsrate und der Verdopplungszeit sind nach $8 \mathrm{~h}, 24 \mathrm{~h}$ und $48 \mathrm{~h}$ die Kulturen geerntet und für die Elektronenmikroskopie vorbereitet worden. Jeweils drei unabhängig voneinander angefertigte Dünnschnitte wurden auf ICM-Strukturen hin untersucht, für jede Probe insgesamt ca. 1500 Zellen. Daraus ist der Quotient aus Zellen, die ICM aufwiesen und der Gesamtzahl an untersuchten Zellen hervorgegangen [ICM/Zelle], welcher der besseren Übersicht halber in eine Prozentangabe umgerechnet wurde. Anschließend sind die spezifischen Aktivitäten membranständiger Dehydrogenasen bei 0,5 molarer Glycerol- bzw. Mannitol-Konzentration ermittelt worden, um einen Zusammenhang zwischen der Menge an ICM/Zelle und einer größeren Anzahl an aktiven enzymatischen Systemen zur unvollständigen Oxidation zu untersuchen. Abschließend sind Immunogold-Markierungen der Polyol-Dehydrogenase an Proben von G. oxydans $621 \mathrm{H}$ durchgeführt worden, die entweder mit 0,5 M Glycerol oder 0,5 M Mannitol angezogen worden sind.

\subsubsection{Das Wachstum von $G$. oxydans $621 \mathrm{H}$ bei unterschiedlichen Konzentrationen von Glycerol und Mannitol}

Das Wachstum von G. oxydans $621 \mathrm{H}$ wurde bei unterschiedlichen Konzentrationen von Glycerol und Mannitol untersucht wie es in Kap. 2.3 beschrieben ist. In der Abb. 3.2.4. sind für Glycerol und in Abb. 3.2.5. sind für Mannitol die entsprechenden Wachstumskurven dargestellt. Die max. Wachstumsraten, die Verdopplungszeiten sowie die nach $48 \mathrm{~h}$ erreichten $\mathrm{OD}_{600}$ sind den Tabellen 3.2.1. und 3.2.2. zu entnehmen. 


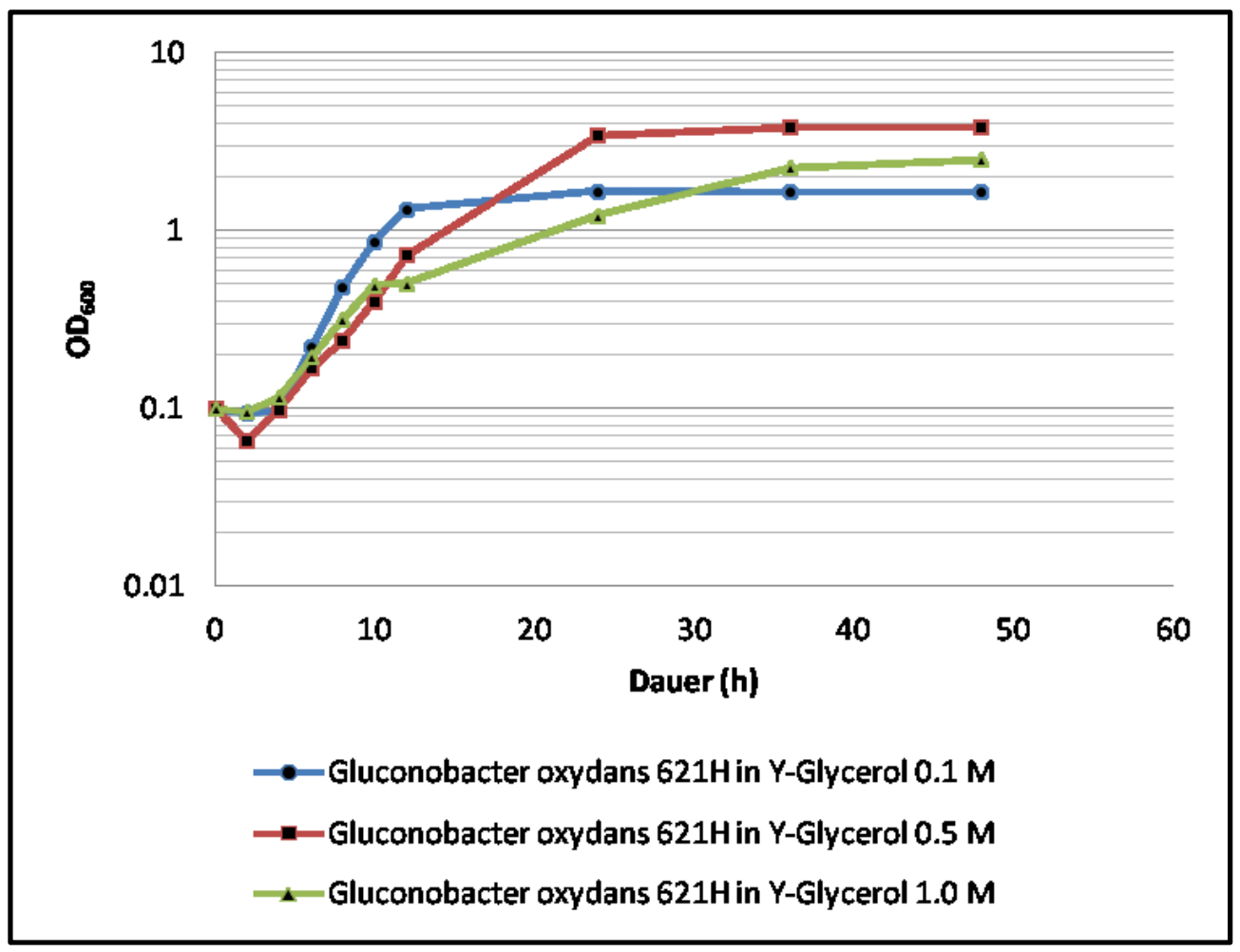

Abb. 3.2.4.: Das Wachstum von G. oxydans 621H bei unterschiedlichen Glycerol-Konzentrationen.

Tabelle 3.2.1.: Wachstumsraten und Verdopplungszeiten von G. oxydans $621 \mathrm{H}$ bei unterschiedlichen Glycerol-Konzentrationen.

\begin{tabular}{cccc}
\hline $\begin{array}{c}\text { Glycerol } \\
{[\text { Mol/Liter }]}\end{array}$ & $\begin{array}{c}\text { max. Wachstumsrate } \\
{[\mathbf{1} / \mathbf{h}]}\end{array}$ & $\begin{array}{c}\text { Verdopplungszeit } \\
{[\mathbf{h}]}\end{array}$ & $\begin{array}{c}\mathbf{O D}_{\mathbf{6 0 0}} \\
\text { nach } \mathbf{4 8 h}\end{array}$ \\
\hline $\mathbf{0 , 1}$ & 0,34 & 2,03 & 1,65 \\
$\mathbf{0 , 5}$ & 0,25 & 2,77 & 3,81 \\
$\mathbf{1 , 0}$ & 0,23 & 2,99 & 2,51 \\
\hline
\end{tabular}

Aus der Abb. 3.2.4. und der Tabelle 3.2.1. ist ersichtlich, dass G. oxydans $621 \mathrm{H}$ beim Wachstum bei $0,5 \mathrm{M}$ Glycerol mit 3,81 die höchste $\mathrm{OD}_{600}$ erreicht, gefolgt von 1,0 M $(2,51)$ und $0,1 \mathrm{M}$ Glycerol $(1,65)$. Bei den max. Wachstumsraten ergibt sich eine klare, den steigenden Glycerol-Konzentration diametral entgegengesetzte Reihenfolge: bei $0,1 \mathrm{M}$ ist sie mit $0,34 / \mathrm{h}$ am höchsten, gefolgt von $0,5 \mathrm{M}(0,25 / \mathrm{h})$ und $1,0 \mathrm{M}(0,23 / \mathrm{h})$. Die jeweiligen Verdopplungszeiten steigen in entsprechend gleicher Reihenfolge. 


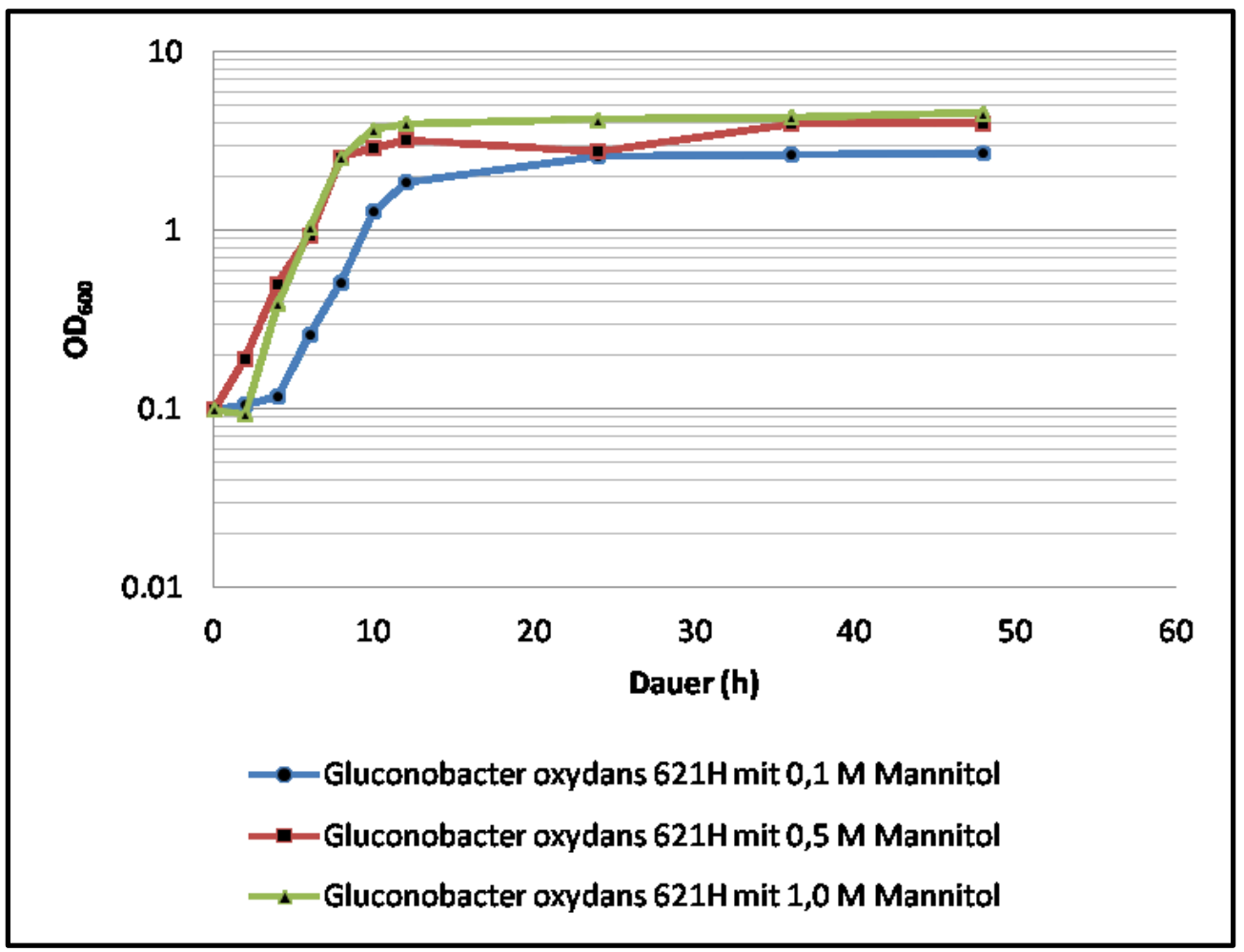

Abb. 3.2.5.: Das Wachstum von G. oxydans 621H bei unterschiedlichen Mannitol-Konzentrationen.

Tabelle 3.2.2.: Wachstumsraten und Verdopplungszeiten von G. oxydans 621H bei unterschiedlichen Mannitol-Konzentrationen.

\begin{tabular}{cccc}
\hline $\begin{array}{c}\text { Mannitol } \\
{[\text { Mol/Liter }]}\end{array}$ & $\begin{array}{c}\text { max. Wachstumsrate } \\
{[\mathbf{1} / \mathbf{h}]}\end{array}$ & $\begin{array}{c}\text { Verdopplungszeit } \\
{[\mathbf{h}]}\end{array}$ & $\begin{array}{c}\text { OD }_{\mathbf{6 0 0}} \\
\text { nach } \mathbf{4 8 h}\end{array}$ \\
\hline $\mathbf{0 , 1}$ & 0,39 & 1,76 & 2,73 \\
$\mathbf{0 , 5}$ & 0,43 & 1,60 & 4,03 \\
$\mathbf{1 , 0}$ & 0,59 & 1,17 & 4,57 \\
\hline
\end{tabular}

Die Wachstumskurve in Abb. 3.1.5. und die Tab. 3.2.2. zeigen, dass G. oxydans $621 \mathrm{H}$ bei 1,0 $\mathrm{M}$ mit 4,57 die höchste $\mathrm{OD}_{600}$ und mit einer max. Wachstumsrate von $0,59 / \mathrm{h}$ die höchsten im Rahmen dieser Arbeit ermittelten Werte erreicht. Beim Wachstum mit 0,5 M Mannitol wird mit 4,03 eine ähnlich hohe $\mathrm{OD}_{600}$ erreicht, bei 0,1 $\mathrm{M}$ ist sie mit 2,73 Mannitol deutlich niedriger. Die max. Wachstumsrate von $0,1 \mathrm{M}$ ist mit 0,40/h am niedrigsten, gefolgt von $0,5 \mathrm{M}(0,43 / \mathrm{h})$ und $1,0 \mathrm{M}(0,59 / \mathrm{h})$. Der Anstieg der max. Wachstumsrate folgt der ansteigenden Mannitol-Konzentration, was im Gegensatz zur Situation mit Glycerol als Substrat steht (Tab. 3.2.1.). 


\subsubsection{Der Quotient [ICM/Zelle] beim Wachstum auf unterschiedlichen}

\section{Konzentrationen von Glycerol und Mannitol}

In den folgenden Abbildungen ist der Quotient aus Zellen, die ICM aufwiesen und der Gesamtzahl an untersuchten Zellen [ICM/Zelle] graphisch dargestellt. Angegeben ist der prozentuale Anteil an Zellen, die ICM aufwiesen. In der ersten Darstellung ist der Quotient zunächst in Abhängigkeit von der Substrat-Konzentration, geordnet nach Wachstumsphasen abgebildet (Abb. 3.2.6.). Dieselben Werte sind anschließend noch einmal in Abhängigkeit zur Wachstumsphase, geordnet nach Konzentration des Substrats gezeigt, um eine generelle Abhängigkeit von der Substratkonzentration zu veranschaulichen (Abb. 3.2.7.).
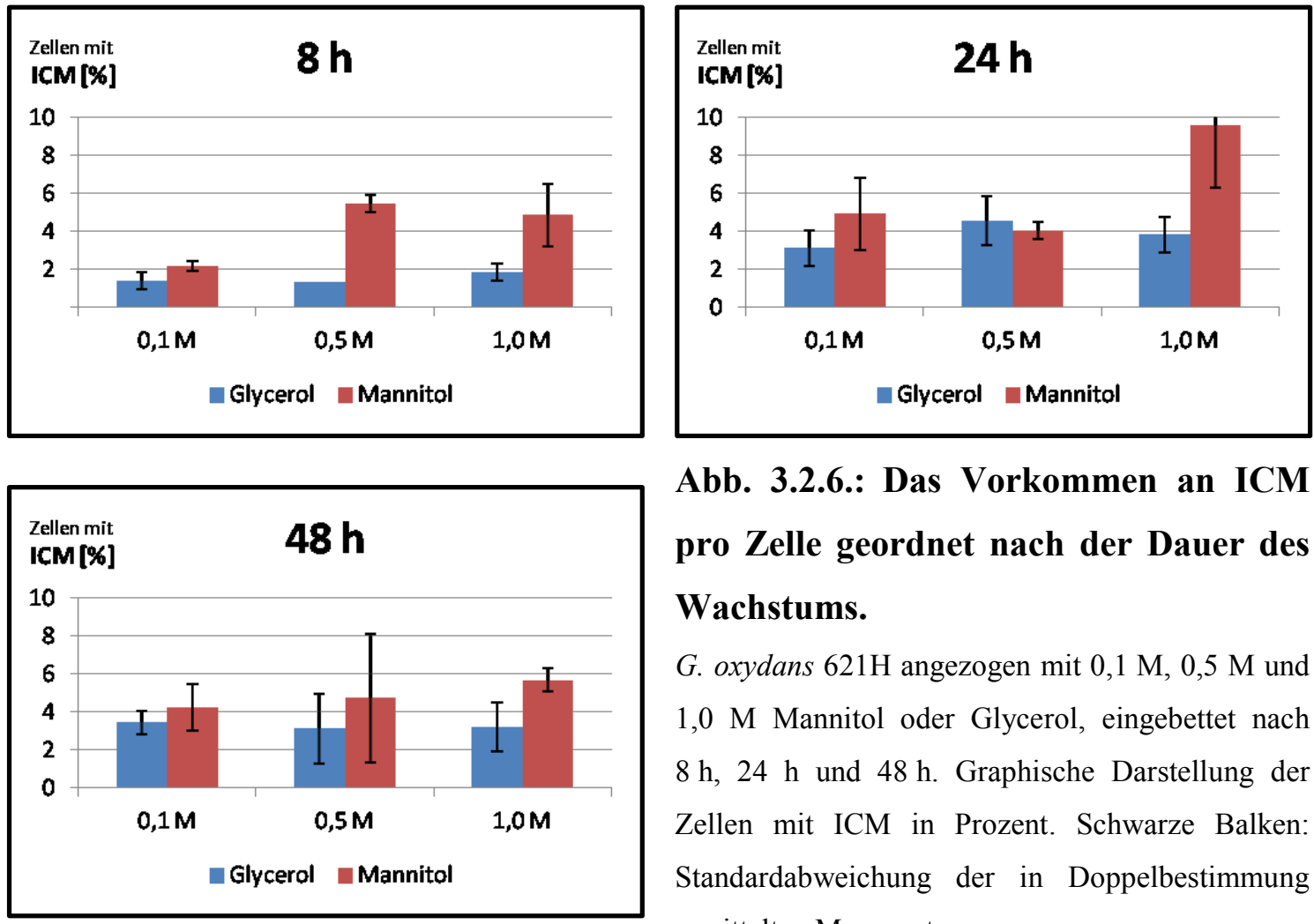

Abb. 3.2.6.: Das Vorkommen an ICM pro Zelle geordnet nach der Dauer des Wachstums.

G. oxydans $621 \mathrm{H}$ angezogen mit $0,1 \mathrm{M}, 0,5 \mathrm{M}$ und 1,0 M Mannitol oder Glycerol, eingebettet nach $8 \mathrm{~h}, 24 \mathrm{~h}$ und $48 \mathrm{~h}$. Graphische Darstellung der Zellen mit ICM in Prozent. Schwarze Balken: Standardabweichung der in Doppelbestimmung ermittelten Messwerte.

Die Anzahl an ICM ist in Proben von Zellen, die mit Mannitol als Substrat gewachsen sind i. d. R. höher als mit Glycerol als Substrat. Ausgenommen sind lediglich die Proben mit 0,5 M Substrat nach 24 h. Aus der Abb. 3.2.6. ist ebenfalls ersichtlich, dass sich nach $24 \mathrm{~h}$ die meisten ICM in den Zellen befanden. 

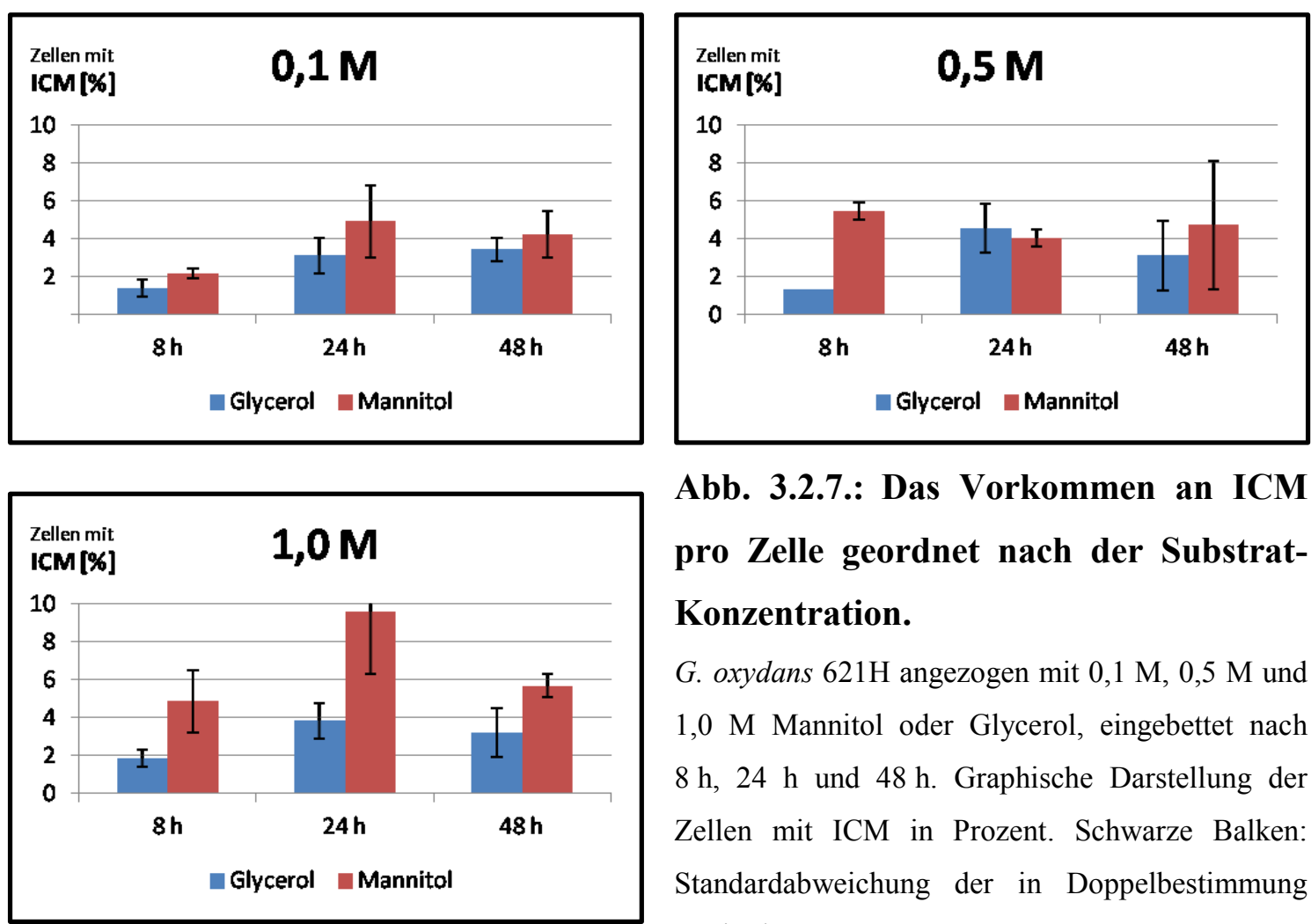

Abb. 3.2.7.: Das Vorkommen an ICM pro Zelle geordnet nach der SubstratKonzentration.

G. oxydans $621 \mathrm{H}$ angezogen mit $0,1 \mathrm{M}, 0,5 \mathrm{M}$ und 1,0 M Mannitol oder Glycerol, eingebettet nach $8 \mathrm{~h}, 24 \mathrm{~h}$ und $48 \mathrm{~h}$. Graphische Darstellung der Zellen mit ICM in Prozent. Schwarze Balken: Standardabweichung der in Doppelbestimmung ermittelten Messwerte.

Zusätzlich zu der Erkenntnis, dass Mannitol als Substrat zu mehr ICM als Glycerol führt, macht die Abb. 3.2.7. deutlich, dass sich mit 1,0 M Substrat wohl die meisten ICM in den Zellen befanden. Es fällt auf, dass bei 0,5 M Mannitol das Aufkommen an ICM/Zelle nach $8 \mathrm{~h}$ am höchsten ist und nach $24 \mathrm{~h}$ um über $20 \%$ zurückgeht. Demgegenüber ist mit 0,5 M Glycerol die Anzahl an ICM/Zelle nach $24 \mathrm{~h}$ deutlich höher ist als nach $8 \mathrm{~h}$. Im folgenden Kapitel wird dieser Sachverhalt mittels Enzymaktivitätstests für membranständige, PQQ-abhängige Dehydrogenasen genauer untersucht.

\subsubsection{Die Aktivität membranständiger Dehydrogenasen des Wildtyp G. oxydans}

\section{$621 \mathrm{H}$, angezogen mit 0,5 M Glycerol und 0,5 M Mannitol}

Das Vorkommen der ICM pro Zelle wurde in Anbetracht der Substratkonzentration und der Wachstumsphase in Kap. 3.1.2 graphisch dargestellt. Wurden die Kulturen mit 0,5 M Glycerol angezogen, so war die Anzahl an ICM/Zelle nach $24 \mathrm{~h}$ deutlich höher als nach $8 \mathrm{~h}$. Im Falle von 0,5 M Mannitol war das Aufkommen an ICM/Zelle nach $8 \mathrm{~h}$ am höchsten und nach $24 \mathrm{~h}$ um über $20 \%$ zurückgegangen. Um einen möglichen Zusammenhang zwischen der Menge an ICM/Zelle und einer größeren Anzahl an 
enzymatisch aktiven Systemen zur unvollständigen Oxidation zu untersuchen, wurden Enzymaktivitätstests durchgeführt (Kap. 2.5.4). In den Abbildung 3.2.8. und 3.2.9. sind die Aktivitäten membranständiger Dehydrogenasen bei 0,5 M Glycerol bzw. Mannitol graphisch dargestellt.
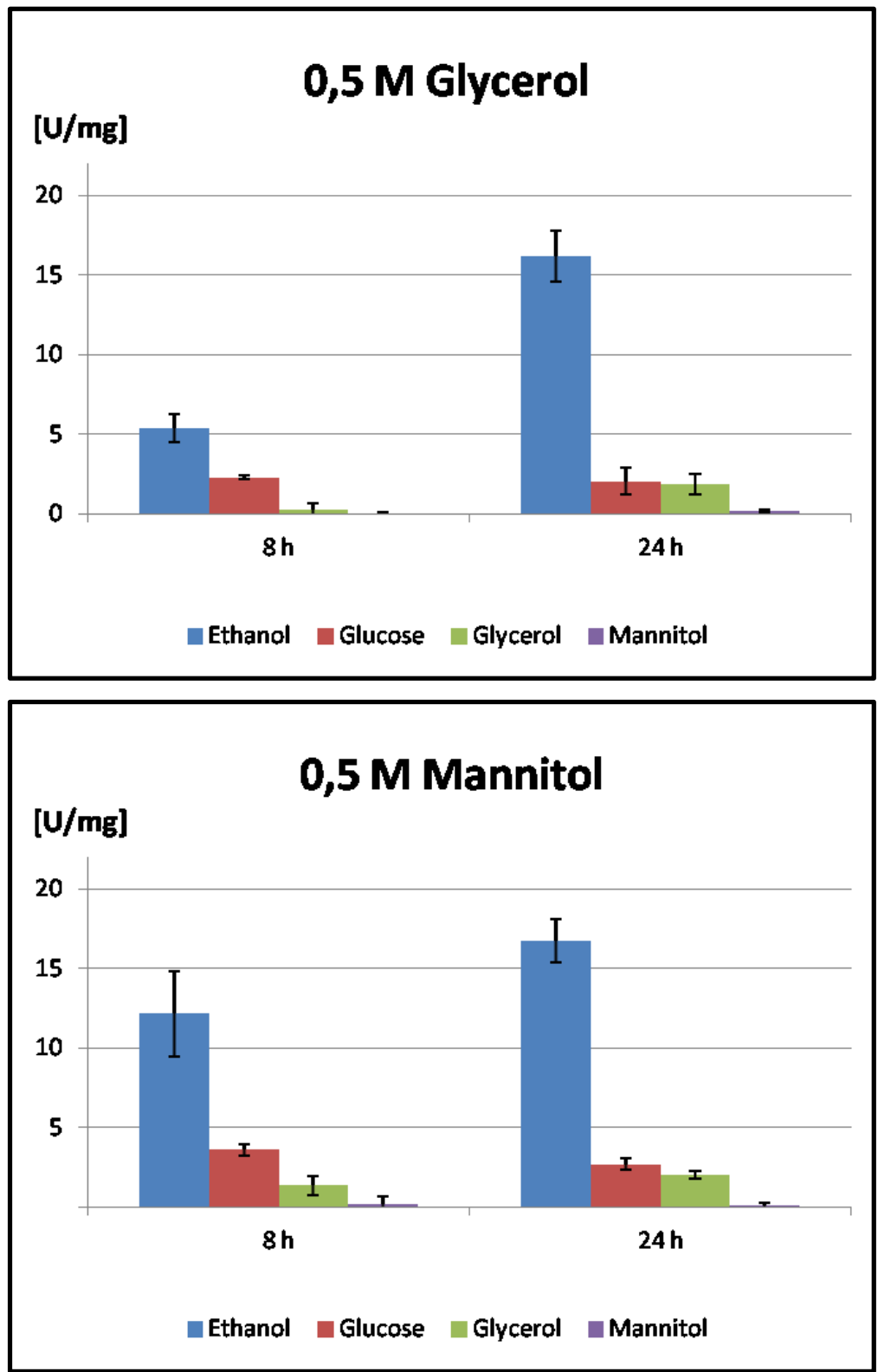

Abb. 3.2.8.: Enzymaktivität G. oxydans 621H angezogen mit 0,5 M Glycerol.

Spezifische Aktivität in [U/mg] beim Umsatz der jeweiligen Substrate mit Membranfraktionen nach 8 h bzw. $24 \mathrm{~h}$ Wachstum. Schwarzen Balken: Standardabweichung zweier unabhängig voneinander durchgeführter Experimente.

Abb. 3.2.9.: Enzymaktivität G. oxydans $621 \mathrm{H}$ angezogen mit 0,5 M Mannitol.

Spezifische Aktivität in [U/mg] beim Umsatz der jeweiligen Substrate mit Membranfraktionen nach $8 \mathrm{~h}$ bzw. $24 \mathrm{~h}$ Wachstum. Schwarzen Balken: Standardabweichung zweier unabhängig voneinander durchgeführter Experimente.

Am geringsten sind die Enzymaktivitäten nach achtstündigem Wachstum auf Glycerol. Nach 24 h sind die Aktivitäten nach der Anzucht auf beiden Substraten am höchsten und von vergleichbarer Größenordnung. Nach $8 \mathrm{~h}$ Wachstum auf Mannitol sind die Aktivitäten deutlich stärker als nach $8 \mathrm{~h}$ Wachstum auf Glycerol. Im Falle der enzymatischen Umsetzung von Glucose zeigten die getesteten Membranfraktionen nach 8 h Wachstum auf Mannitol sogar die höchste Aktivität. Die Aktivitäten steigen im 
Falle von Ethanol und Glycerol als Substrat von exp. zur stat. Wachstumsphase an, mit Glucose als Substrat sinken die Werte. Die schwache Aktivität gegenüber Mannitol als Substrat steigt beim Wachstum mit Glycerol von exp. zur stat. Wachstumsphase an, während sie beim Wachstum mit Mannitol abnimmt.

\subsubsection{Lokalisierung der großen Untereinheit der Membran-gebundenen PQQ-} abhängigen Polyol-Dehydrogenase GOX0854 beim Wachstum mit 0,5 M Substrat

Die in Kap. 3.2.2 gemachten Beobachtungen wurden abschließend mittels ImmunogoldMarkierungen der großen UE der Polyol-Dehydrogenase GOX0854 untersucht. In Übereinstimmung mit den Enzymaktivitätstests wurden Proben von Kulturen untersucht, die über $8 \mathrm{~h}$ und $24 \mathrm{~h}$ mit 0,5 M Glycerol, resp. Mannitol angezogen worden sind. Die TEM-Mikrographien sind in den Abb. 3.2.10 und 3.2.11. dargestellt.
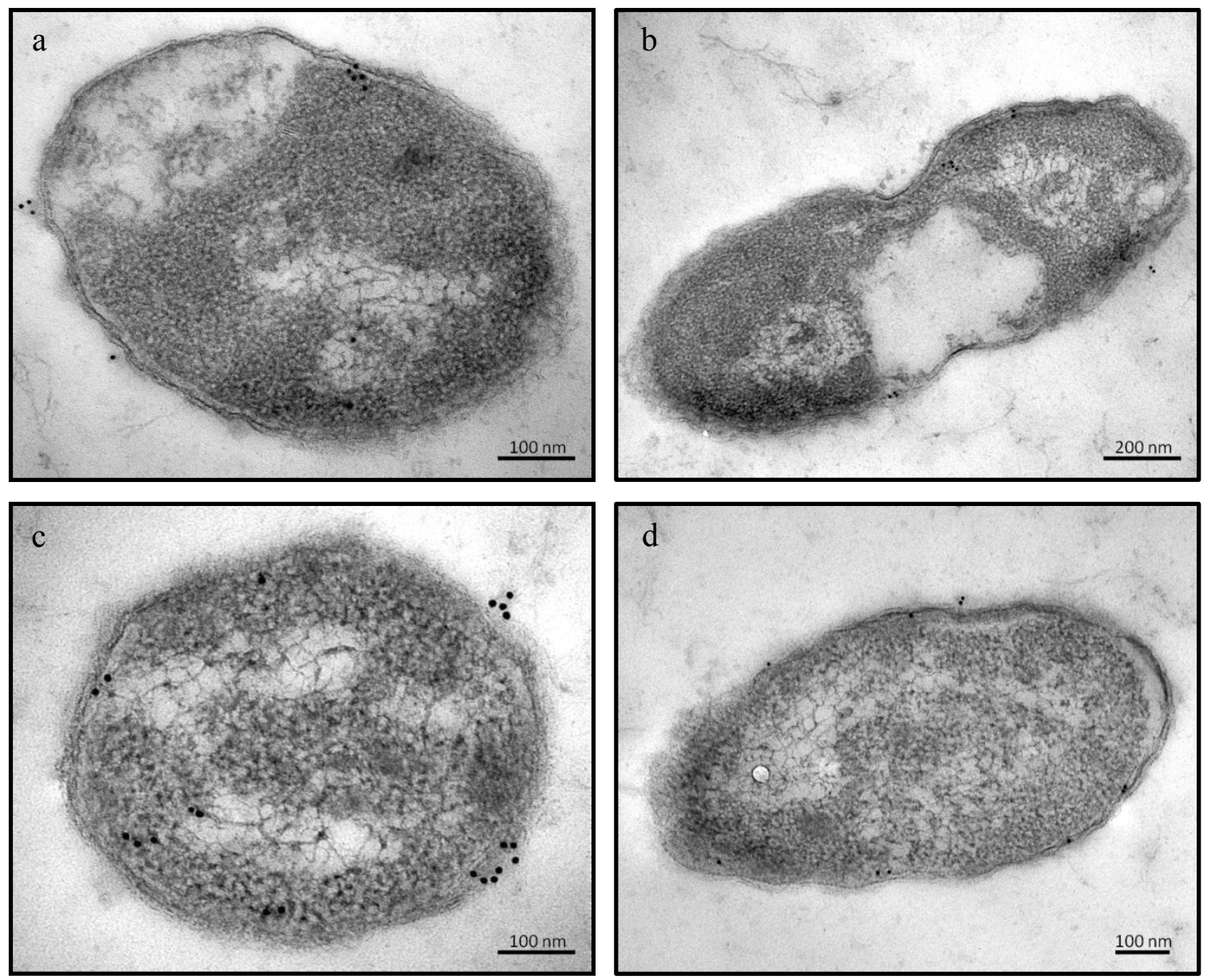

Abbildung 3.2.10.: G. oxydans 621H mit 0,5 M Glycerol über 8 h und 24 h angezogen und Immunogold-markierter GOX0854.

TEM-Elektronenmikrograhien von G. oxydans 621H, markiert mit dem Antikörper gegen GOX0854. Die Anzucht erfolgte über $8 \mathrm{~h}$ ( $\mathrm{a}$ und b), sowie $24 \mathrm{~h}$ (c und d) mit 0,5 M Glycerol, 200 upm und bei $30^{\circ} \mathrm{C}$. 
Die Stärke der Immunogold-Markierung nach 8 h Wachstum mit 0,5 M Glycerol (Abb. 3.2.10.a und b) ist signifikant schwächer als nach 24 h (Abb.3.2.10.c und d). Auf den hier gezeigten Bildern aus der stat. Wachstumsphase nach $24 \mathrm{~h}$ sind insgesamt doppelt so viele Positionen an der Cytoplasmamembran mit einer unterschiedlichen Anzahl an Goldpartikeln markiert, als auf den Bildern aus der exp. Wachstumsphase nach $8 \mathrm{~h}$.
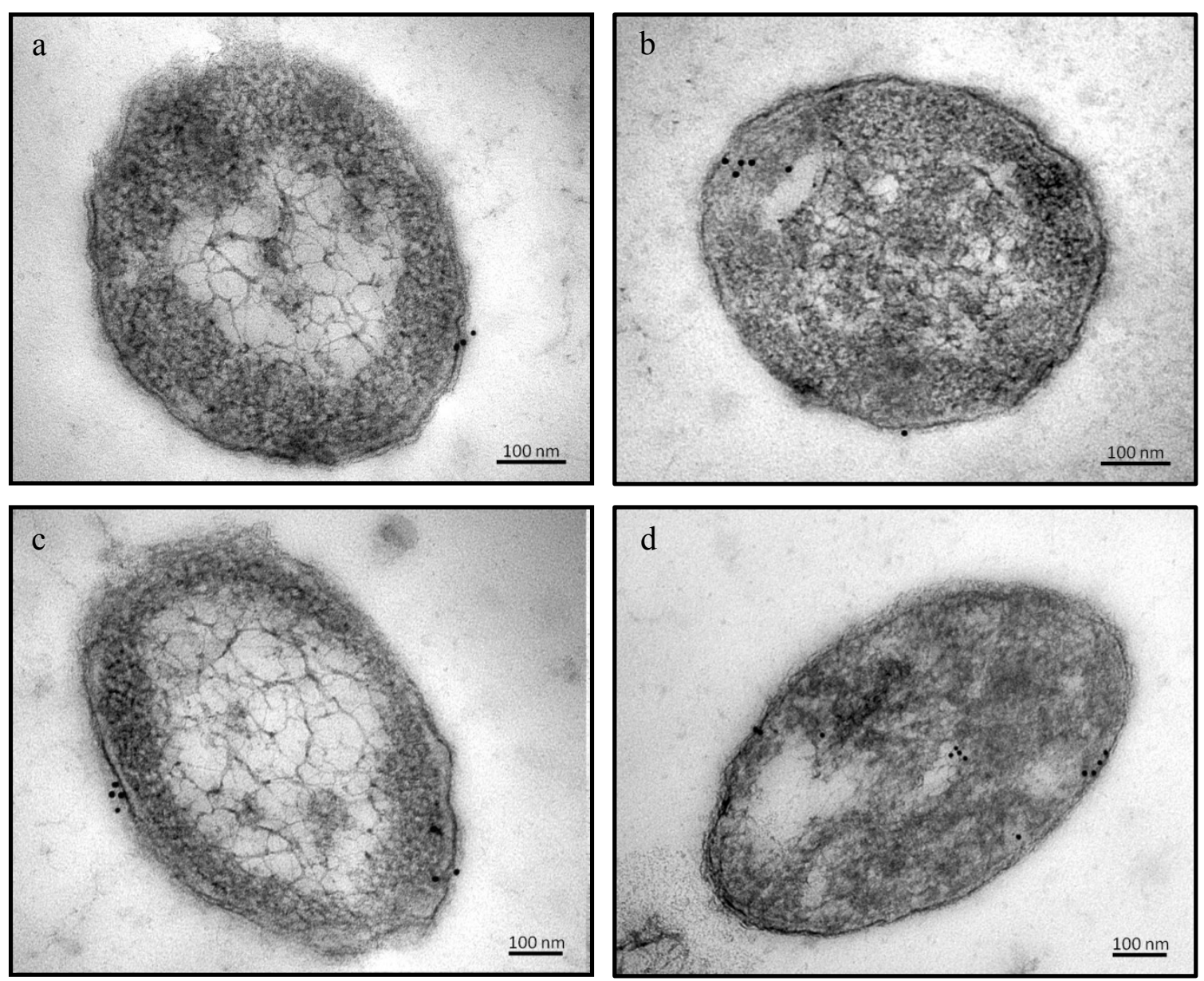

Abbildung 3.2.11.: G. oxydans 621H mit 0,5 M Mannitol über 8 h und 24 h angezogen und Immunogold-markierter GOX0854.

Die Abb. 3.2.11. zeigt TEM-Elektronenmikrograhien von G. oxydans 621H, markiert mit dem Antikörper gegen die große Untereinheit der membranständigen Polyoldehydrogenase GOX0854. Die Anzucht erfolgte über $8 \mathrm{~h}$ ( $\mathrm{a}$ und b), sowie $24 \mathrm{~h}$ (c und d) mit 0,5 M Mannitol, 200 upm und bei $30^{\circ} \mathrm{C}$.

Die Stärke der Immunogold-Markierung nach $8 \mathrm{~h}$ Wachstum mit 0,5 M Mannitol (Abb. 3.2.11.a und b) ist nur unwesentlich schwächer als nach 24 h (Abb. 3.2.11.c und d). Die Markierung an Zellen aus der stat. Wachstumsphase nach $24 \mathrm{~h}$ entspricht in der Intensität den Zellen aus der exp. Wachstumsphase nach $8 \mathrm{~h}$ Wachstum mit 0,5 M Glycerol (Abb. 3.2.10.a und b). 


\subsection{G. oxydans $621 \mathrm{H}$ bei verringertem Sauerstoffeintrag}

Im Verlauf dieser Arbeit ist aufgefallen, dass die Anzucht von G. oxydans $621 \mathrm{H}$ mit einer relativ niedrigen Rotationsgeschwindigkeit zu einer signifikanten Steigerung der Aktivität membranständiger Dehydrogenasen führen kann. Dies war insbesondere mit dem Substrat Ethanol in allen Wachstumsphasen zu beobachten. Mit den Substraten Glucose, Glycerol und Mannitol waren in der stationären Phase erhöhte Aktivitäten messbar (Kap. 3.3.2). Es ist davon auszugehen, dass bei einer geringeren Rotationsgeschwindigkeit weniger Sauerstoff im Medium gelöst ist (SCHIEFELBEIN et al., 2013).

Zunächst wird in Kap. 3.3.1 das Wachstum von G. oxydans $621 \mathrm{H}$ unter Standardbedingungen und Sauerstoffmangel dargestellt. Neben den bereits erwähnten Enzymaktivitätstests wurden in den Kap. 3.3.3 und 3.3.4 die Auswirkungen des Wachstums mit weniger Sauerstoff auf die Expression von GOX1912, resp. GOX0854 mittels Immunogold-Markierung und Western Blot-Analysen analysiert.

\subsubsection{Das Wachstum von $G$. oxydans $621 \mathrm{H}$ bei verringertem Sauerstoffeintrag}

Das Wachstum von G. oxydans $621 \mathrm{H}$ wurde wie im Kap. 2.3.2 beschrieben untersucht und die max. Wachstumsrate sowie die Verdopplungszeit ermittelt, wie es in Kap. 2.3.3 beschrieben ist. In der Abb. 3.3.1. sind die Wachstumskurven bei Standardbedingungen und bei der Anzucht mit verringerter Rotationsgeschwindigkeit dargestellt. 


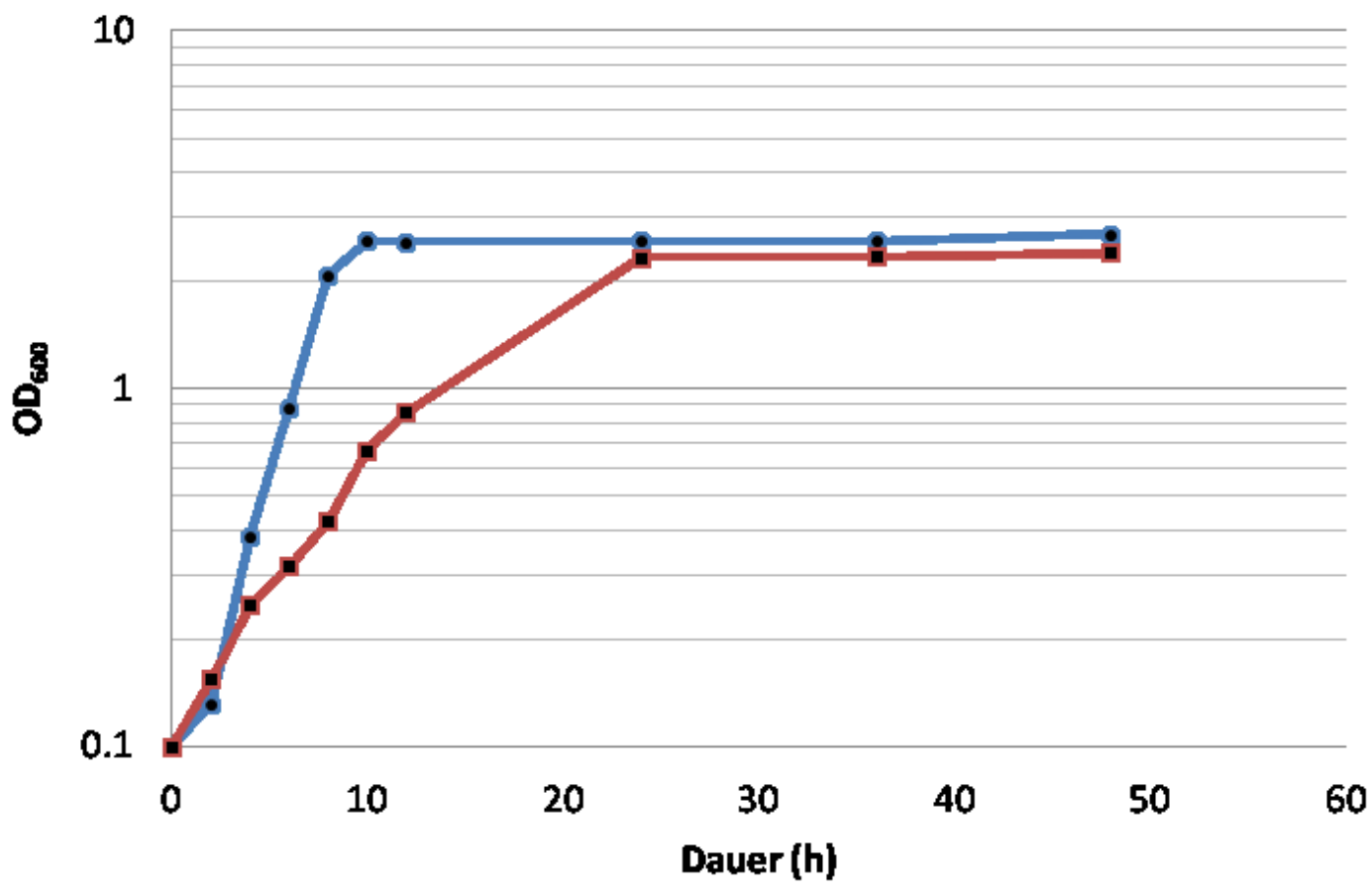

$\longrightarrow$-Standardbedingungen, $200 \mathrm{rpm}, 30^{\circ} \mathrm{C}$

$\rightarrow-$ Sauerstoffmangel, $50 \mathrm{rpm}, 30^{\circ} \mathrm{C}$

Abb. 3.3.1.: Das Wachstum von $G$. oxydans $621 \mathrm{H}$ bei unterschiedlichen

\section{Rotationsgeschwindigkeiten.}

Standard Mannitol-Medium, bei $30^{\circ} \mathrm{C}$, sowie 200 und 50 upm.

Aus der Abb. 3.3.1 ist ersichtlich, dass G. oxydans $621 \mathrm{H}$ bei verringerter Rotationsgeschwindigkeit eine geringere $\mathrm{OD}_{600}$ erreicht $(2,53)$ als unter Standardbedingungen $(2,70)$. Um die stat. Phase zu erreichen benötigt der Wildtyp bei 50 upm mit 24 h doppelt so viel Zeit wie unter Standardbedingungen mit $12 \mathrm{~h}$. Daraus ergeben sich max. Wachstumsraten von $0,46 / \mathrm{h}$ im Falle der Standardanzucht und von $0,18 / \mathrm{h}$ bei verringerter Rotationsgeschwindigkeit. Die sich daraus ergebenden Verdopplungszeiten sind $1,51 \mathrm{~h}$ bei Standardanzucht und $3,76 \mathrm{~h}$ bei verringerter Rotationsgeschwindigkeit.

\subsubsection{Die Enzymaktivität von $G$. oxydans $621 \mathrm{H}$ bei verringertem Sauerstoffeintrag}

Die Aktivität membranständiger Dehydrogenasen, die bei der Oxidation frei werdende Elektronen via PQQ dem Ubiquinon-Pool zuführen, wurde für Membranfraktionen des 
Wildtyps G. oxydans $621 \mathrm{H}$, angezogen unter Standardbedingungen, sowie mit reduzierter Rotationsgeschwindigkeit bestimmt. Es wurden jeweils Proben aus der exp. Phase, dem Zeitpunkt des Übergangs von der exp. zur stat. Phase und der frühen stat. Phase untersucht. Im Verlauf des in Kap. 2.5.4 beschriebenen Aktivitätstests werden die Elektronen über Phenazinmethosulfat (PMS) auf den artifiziellen Elektronenakzeptor Dichlorphenolindophenol (DCPIP) übertragen, dessen Reduktion photometrisch verfolgt werden kann (VOSS et al., 2010). In der Abbildung 3.3.2. ist die Aktivität membranständiger Dehydrogenasen unter Standardbedingungen, in der Abbildung 3.3.3. bei Sauerstoffmangel graphisch dargestellt.

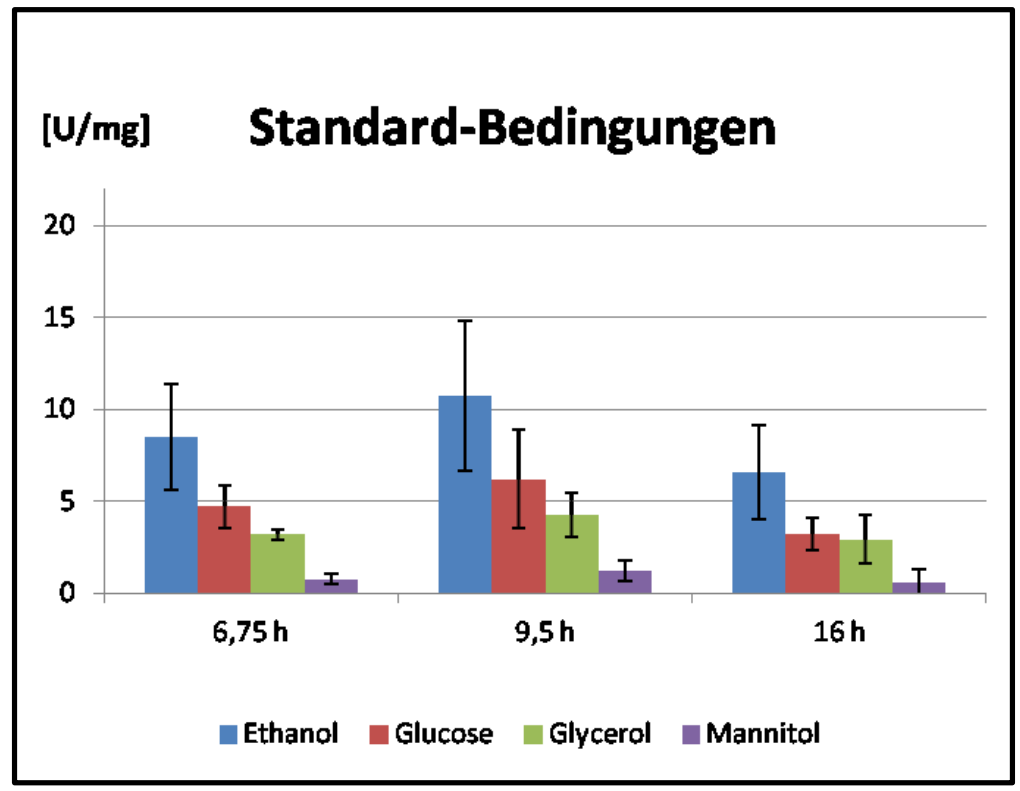

Abb. 3.3.2.:

Enzymaktivität Wildtyp G. oxydans $621 \mathrm{H}$ unter Standardbedingungen.

Spezifische Aktivität in [U/mg] abhängig von Substrat und Wachstumsphase. Schwarze Balken: Standardabweichung, ermittelt durch Messwerte zweier voneinander unab-hängiger Experimente.

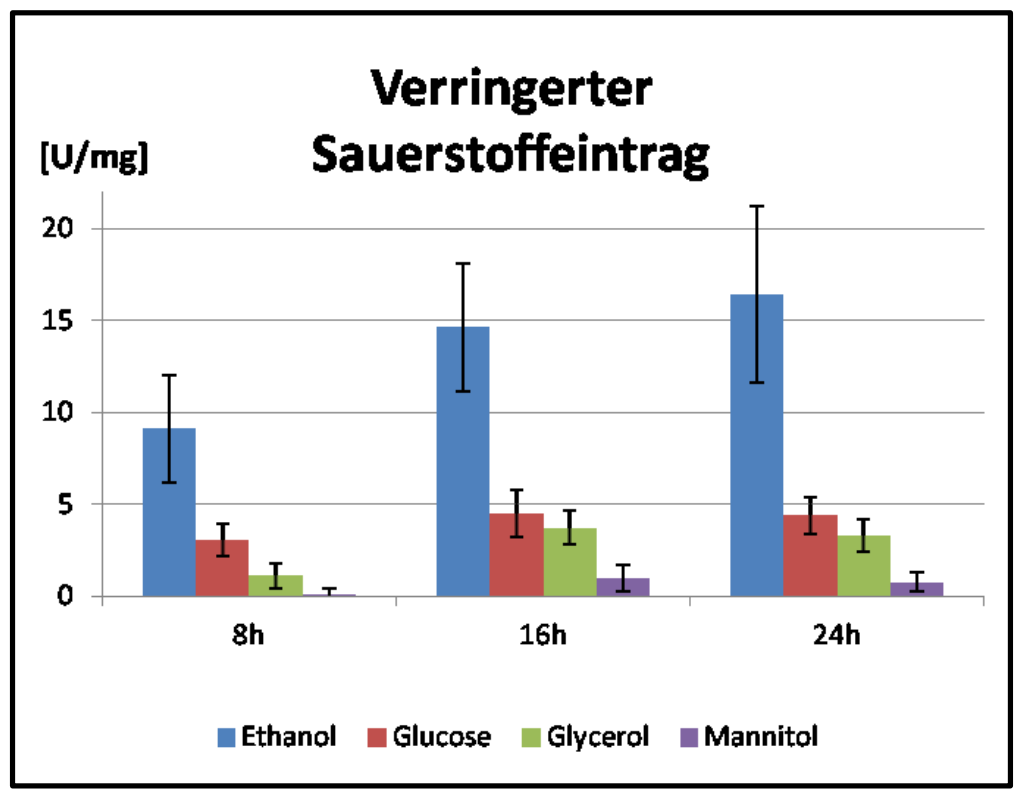

Abb. 3.3.3.:

Enzymaktivität Wildtyp G. oxydans $621 \mathrm{H}$ bei Sauerstoffmangel.

Spezifische Aktivität in [U/mg] abhängig von Substrat und Wachstumsphase. Schwarze Balken: Standardabweichung, ermittelt durch Messwerte zweier voneinander unab-hängiger Experimente. 
Gegenüber Ethanol als Substrat ist die spezifische Aktivität unter Sauerstoffmangel in allen getesteten Wachstumsphasen höher als unter Standardbedingungen, in der frühen stat. Phase ist sie sogar um das Doppelte erhöht. Zu diesem Zeitpunkt scheint sie ihren Höchstwert zu erreichen, was sich aber in Anbetracht der größeren Standardabweichung nicht sicher belegen lässt. Generell gehen bei 200 upm die Enzymaktivitäten der Membranfraktionen im Verlauf des Wachstums leicht zurück, während sie bei 50 upm relativ konstant bleiben.

Die Enzymaktivität der Membranfraktionen gegenüber den Substraten Glucose, Glycerol und Mannitol weisen zwischen den getesteten Bedingungen in der frühen und späten exp. Phase keine signifikanten Unterschiede auf. In der frühen und späten exp. Phase sind die ermittelten Aktivitäten bei 200 upm höher als bei 50 upm, während es sich in der stat. Phase umgekehrt verhält.

\subsubsection{Detektion der großen Untereinheit der membrangebundenen PQQ-abhängigen Polyol-Dehydrogenase GOX0854 an Proben des Wildtyps G. oxydans 621H und der Deletionsmutante G. oxydans $\Delta u p p$ $\Delta$ gox1911-1914 bei verringertem Sauerstoffeintrag}

Die Expression der Polyol-Dehydrogenase GOX0854/0855 wurde im Hinblick auf die im Medium gelöste Menge an Sauerstoff und der Wachstumsphase mittels Western Blot-Analyse und Immunogold-Markierung untersucht. In der Western Blot-Analyse wurde darüber hinaus der Einfluss der Deletion der Quinol-Oxidase des bo3-Typs auf die Expression von GOX0854/0855 überprüft. Hierfür wurden Zellen des Wildtyps G. oxydans $621 \mathrm{H}$ und der Deletionsmutante G. oxydans $\Delta$ upp $\Delta$ gox1911-1914 bei 200 upm und $50 \mathrm{upm}$ angezogen und nach $8 \mathrm{~h}$ sowie $30 \mathrm{~h}$ geerntet. Der entsprechende Western Blot mit dem 1000fach verdünnten GOX0854-Strep Antikörperserum ist in der Abb. 3.3.4. gezeigt. 


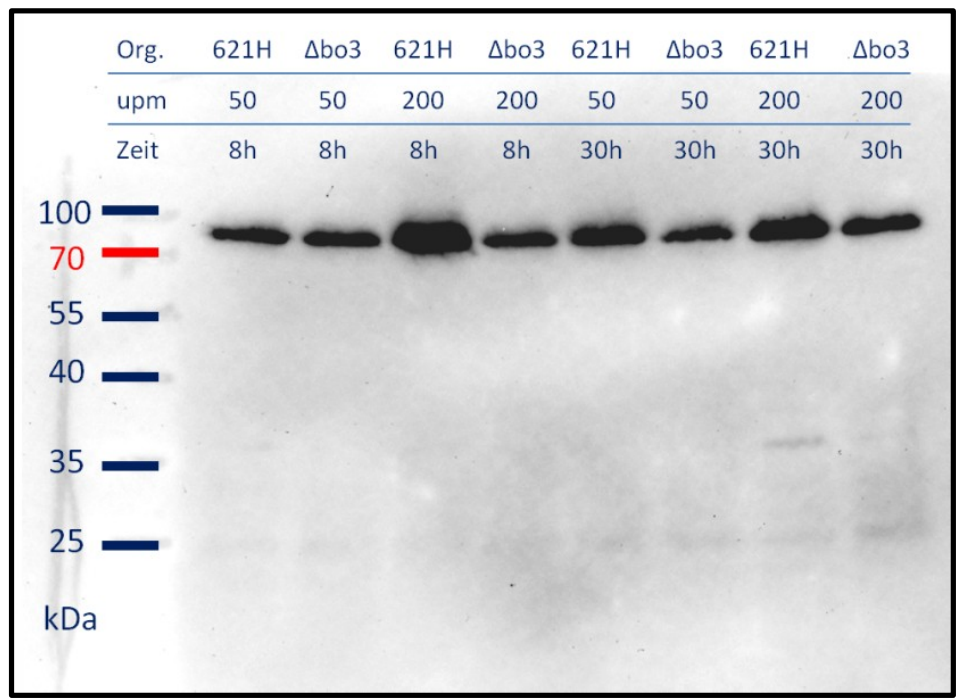
Abb. 3.3.4: Western Blot mit dem GOX0854-Strep Antikörper.

Wildtyp G. oxydans $621 \mathrm{H}$ und Deletionsmutante Aupp $\triangle$ gox19111914, jeweils $20 \mu \mathrm{g}$ Rohextrakt, bei 200 upm und 50 upm nach $8 \mathrm{~h}$ und $30 \mathrm{~h}$ in Mannitol-Medium. Das Antikörper-Serum wurde 1000 fach verdünnt eingesetzt. Mw von GOX0854: 79,6 kDa.

In der Abb. 3.3.4. ist die stärkste Expression von GOX0854/0855 in der Probe des Wildtyps nach $8 \mathrm{~h}$ Wachstum bei $200 \mathrm{upm}$ zu erkennen, was der Anzucht unter Standardbedingungen und Zellen aus der exp. Wachstumsphase entspricht (Abb. 3.3.1.). Bei 50 upm zeigt der Wildtyp nach 30 h eine leicht erhöhte Expression im Vergleich zu der 8 h-Probe unter den gleichen Bedingungen. Diese ist in etwa so stark wie nach $30 \mathrm{~h}$ unter Standardbedingungen. Darüber hinaus ist die Expression im Wildtyp generell etwas stärker ist als in der Deletionsmutante, die relativ unabhängig von der Wachstumsphase und der Rotationsgeschwindigkeit auf konstantem Niveau exprimiert wird.

Um die Expression der Polyol-Dehydrogenase mittels Immunogold-Markierung im Hinblick auf die im Medium verfügbare Sauerstoffkonzentration zu untersuchen, wurden G. oxydans $621 \mathrm{H}-\mathrm{Kulturen}$ bei Rotationsgeschwindigkeiten von $200 \mathrm{upm}$ und 50 upm über $8 \mathrm{~h}$ und $24 \mathrm{~h}$ angezogen und für die TEM vorbereitet, wie es in Kapitel 2.6.3 beschrieben ist. Mit dem 1000-fach verdünnten Antikörper gegen GOX0854 wurden die Ultradünnschnitte Immunogold-markiert und anschließend mikroskopiert. Elektronen-mikrographien von Zellen dieser Kulturen sind in den Abbildung 3.3.5. und 3.3.6. zu sehen. 

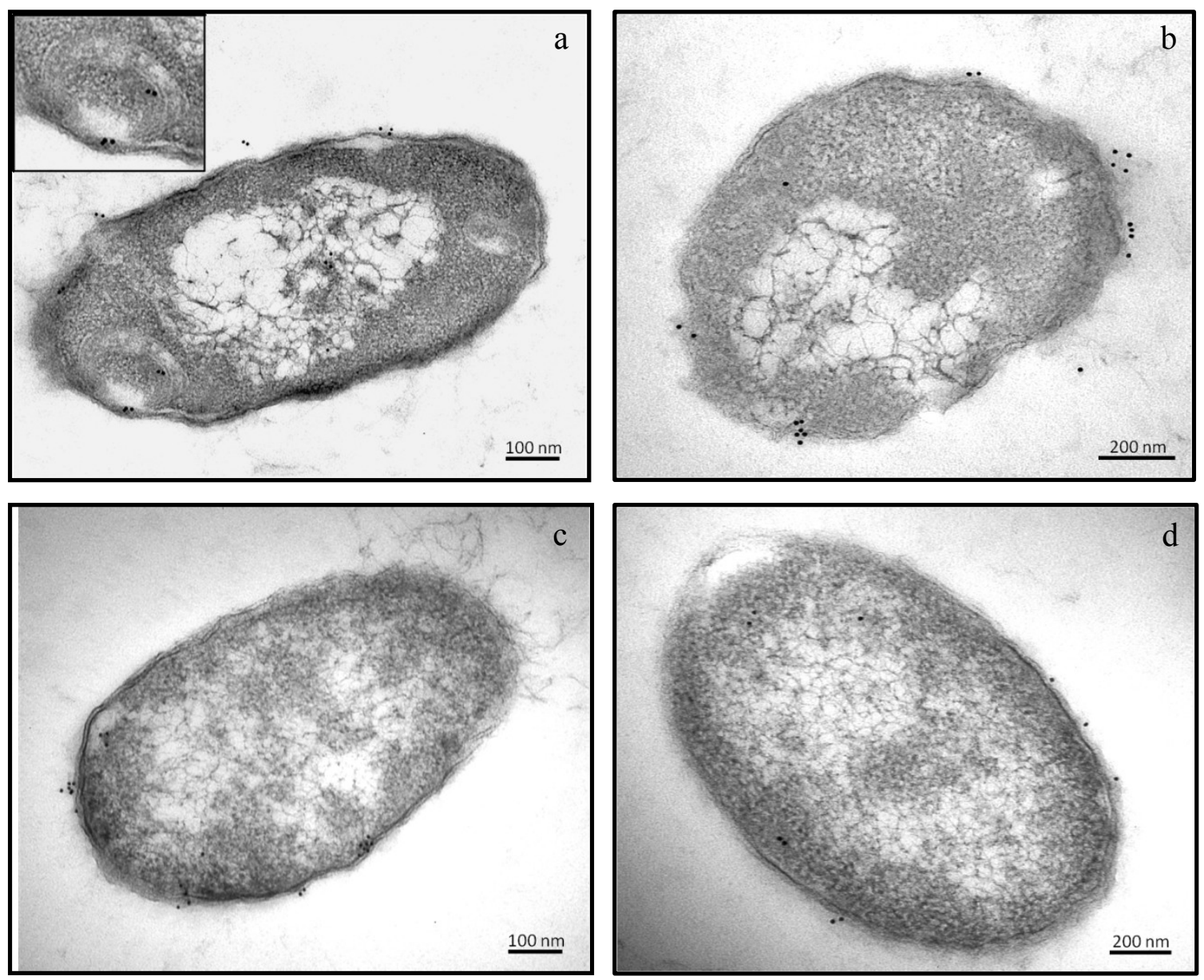

Abbildung 3.3.5.: Wildtyp G. oxydans 621H, angezogen mit unterschiedlichen

\section{Rotationsgeschwindigkeiten über $8 \mathrm{~h}$ und Immunogold-markierter GOX0854.}

Die Abbildungen 3.3.5.a bis d zeigen TEM-Elektronenmikrograhien von G. oxydans 621H, die mit dem Antikörper gegen GOX0854 markiert wurden. Die in Kunstharz eingebetteten Zellkulturen wurden zuvor in Standard Mannitol-Medium für $8 \mathrm{~h}$ bei $200 \mathrm{upm}$ ( $\mathrm{a}$ und b), bzw. für $8 \mathrm{~h}$ bei 50 upm (c und d) angezogen.

Die Quantität der Immunogold-Markierung der Zellen von G. oxydans $621 \mathrm{H}$ ist unter den getesteten Bedingungen ähnlich. Markiert ist vor allem der Bereich der Zellperipherie. Die Intensität der Markierung scheint im Falle der Anzucht mit 200 upm über $8 \mathrm{~h}$ etwas stärker zu sein als mit 50 upm über den gleichen Zeitraum. In der Abb. 3.3.5.a ist in einem vergrößerten Ausschnitt eine markierte ICM zu sehen. 

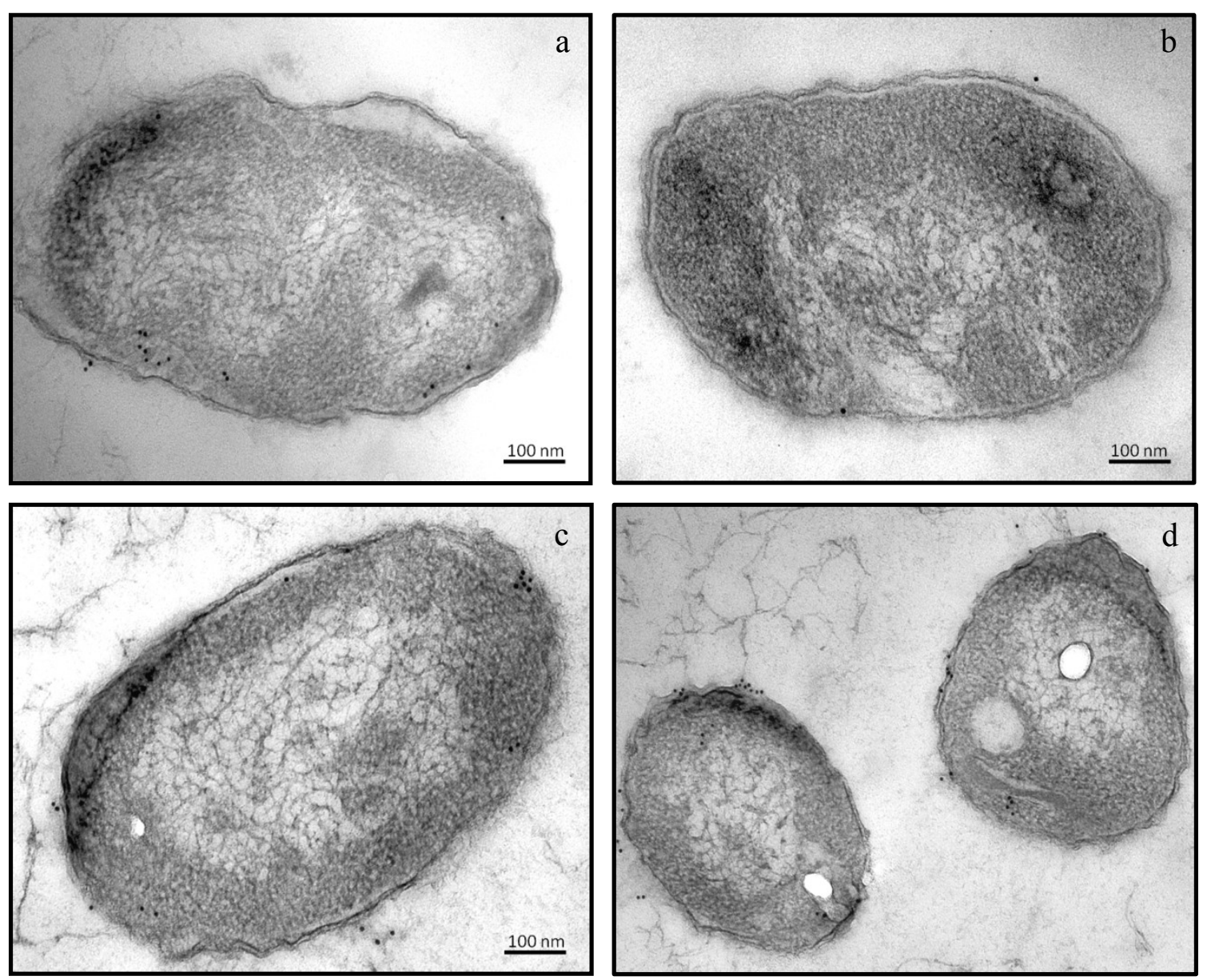

Abbildung 3.3.6.: Wildtyp G. oxydans 621H, angezogen mit unterschiedlichen Rotationsgeschwindigkeiten über 24 h und Immunogold-markierter GOX0854.

Die Abbildungen 3.3.6.a bis d zeigen TEM-Elektronenmikrograhien von G. oxydans $621 \mathrm{H}$, die mit dem Antikörper gegen GOX0854 markiert wurden. Die in Kunstharz eingebetteten Zellkulturen wurden zuvor in Standard Mannitol-Medium für $24 \mathrm{~h}$ bei 200 upm (a und b), bzw. für $24 \mathrm{~h}$ bei 50 upm (c und d) angezogen.

Die Immunogold-Markierung beschränkt sich auch hier auf die Zellperipherie und ist nach $24 \mathrm{~h}$ Wachstum bei verringertem Sauerstoffeintrag etwas intensiver als nach $24 \mathrm{~h}$ Wachstum unter Standardbedingungen. Die Markierungen scheinen nach 8 h Wachstum bei 200 upm (Abb. 3.3.5. a und b), sowie nach 24 h Wachstum bei 50 upm (Abb. 3.3.6. c und d) insgesamt am stärksten zu sein und ähneln einander in Qualität und Quantität. 


\subsubsection{Detektion/Lokalisierung der großen Untereinheit der Quinol-} Oxidase des bo3-Typs GOX1912 und der Deletionsmutante G. oxydans 621H $\Delta$ upp Agox1911-1914 an Proben des Wildtyps bei verringertem Sauerstoffeintrag

Die Expression der Quinol-Oxidase des bo3-Typs GOX1911-1914 wurde im Hinblick auf die im Medium gelöste Menge an Sauerstoff und der Wachstumsphase mittels Western Blot-Analyse und Immunogold-Markierung untersucht. Hierfür wurden Zellen des Wildtyps G. oxydans 621H und der Deletionsmutante G. oxydans $\Delta$ upp Agox19111914 bei Rotationsgeschwindigkeiten von 200 upm und 50 upm angezogen und nach 8 h sowie 30 h geerntet. Der entsprechende Western Blot mit dem 1000fach verdünnten, aufgereinigten GOX1912-Antikörper ist in der Abb. 3.3.7. gezeigt.

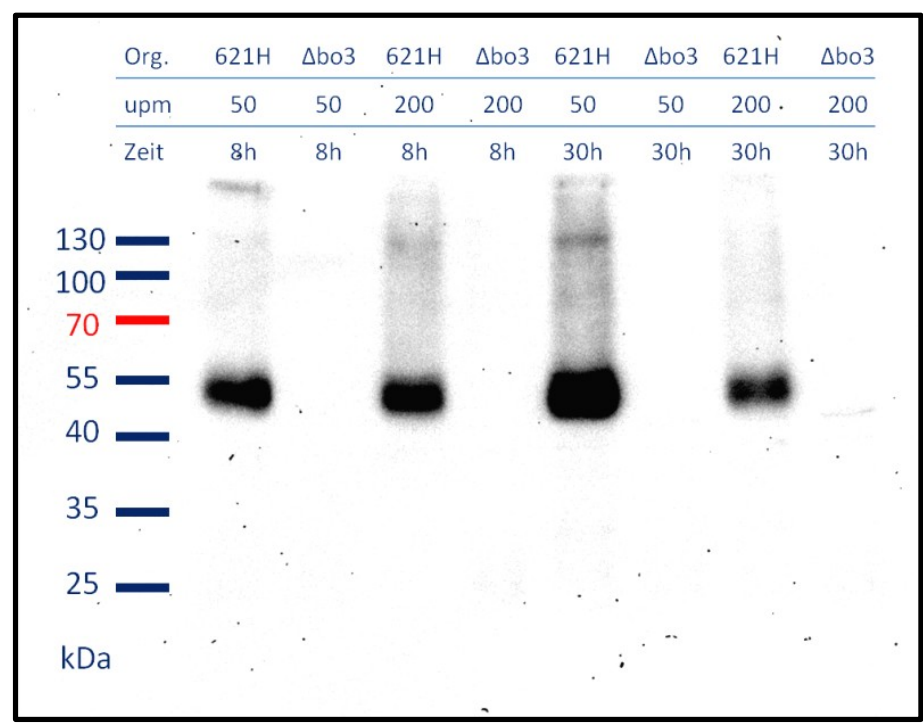

\begin{abstract}
Abb. 3.3.7.: Western Blot mit dem GOX1912 Antikörper. Wildtyp G. oxydans $621 \mathrm{H}$ und Deletionsmutante Aupp 4 gox19111914 bei 200 upm und 50 upm nach $8 \mathrm{~h}$ sowie $30 \mathrm{~h}$ Wachstum. Das Antikörper-Serum wurde 1000fach verdünnt eingesetzt. Die Proteinmenge der Rohextrakte betrug jeweils $20 \mu \mathrm{g}$. Beide Stämme wurden in Mannitol-Medium angezogen. $\mathrm{Mw}$ von GOX1912: ca. 74 kDa.
\end{abstract}

Der Western Blot in Abb. 3.3.7. zeigt, dass GOX1912 am stärksten exprimiert ist, wenn die Zellen bei 50 upm über $30 \mathrm{~h}$ angezogen wurden und sich damit in der stat. Wachstumsphase befinden (Abb. 3.3.1.). Nach 30 h bei 200 upm ist die Expression am schwächsten, die Zellen sind dann in einer fortgeschrittenen stat. Phase. Nach $8 \mathrm{~h}$ besteht zwischen der Anzucht bei 50 und 200 upm kein signifikanter Unterschied. Beide Zellkulturen befinden sich in der exp. Phase und die relative Stärke der Expression liegt hier im mittleren Bereich des Experiments.

G. oxydans $621 \mathrm{H}-\mathrm{Kulturen}$ wurden bei Rotationsgeschwindigkeiten von $200 \mathrm{upm}$ und 50 upm über 8 h sowie $24 \mathrm{~h}$ angezogen und für die TEM vorbereitet, wie es in Kapitel 
2.6.3 beschrieben ist. Anschließend sind Ultradünnschnitte der eingebetteten Proben mit dem Antikörper gegen GOX1912 in einer Verdünnung von 1:100 Immunogold-markiert und mikroskopiert worden. Elektronenmikrographien von Zellen dieser Kulturen sind in den Abb. 3.3.8. für $8 \mathrm{~h}$ sowie 3.3.9. für $24 \mathrm{~h}$ zu sehen.
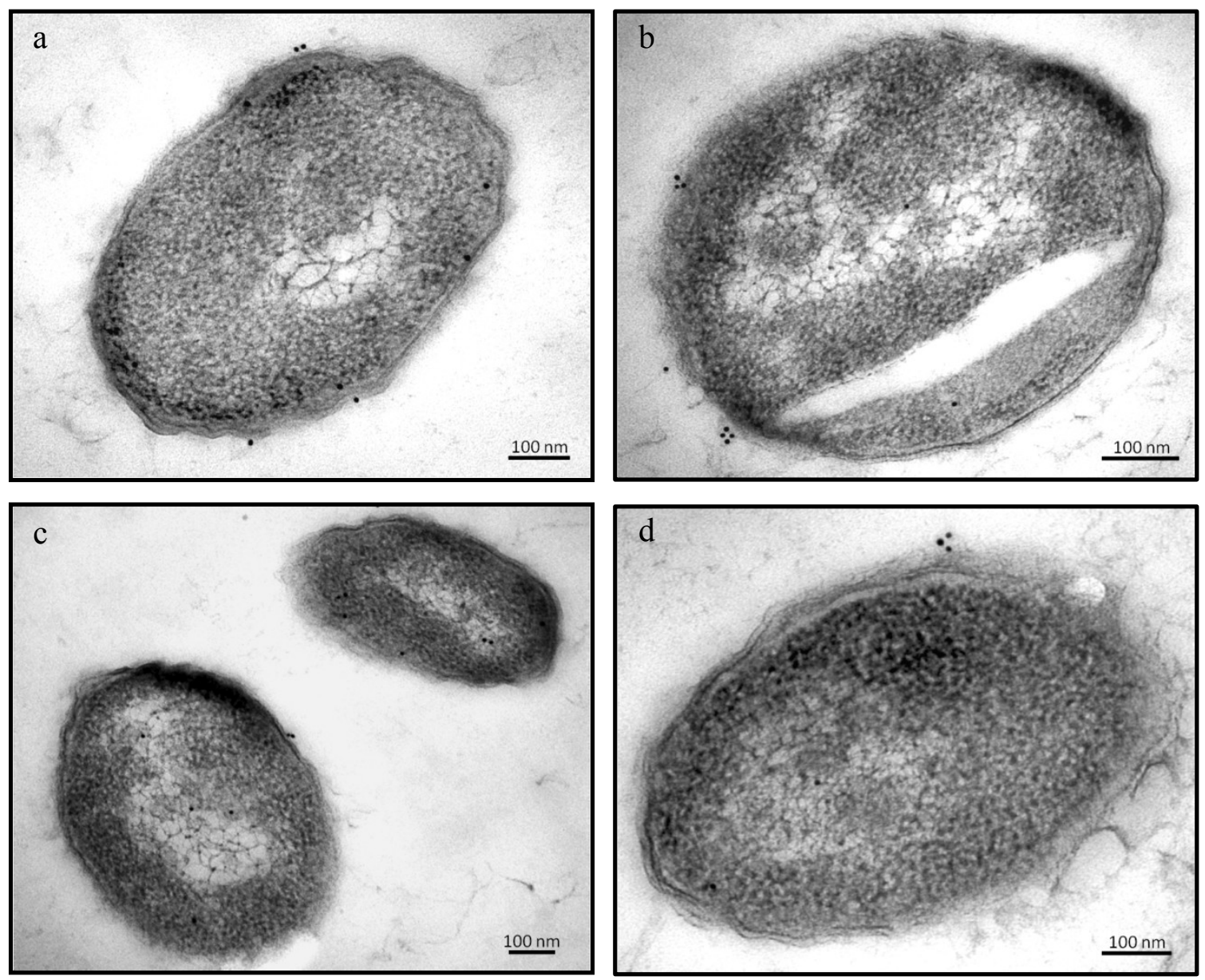

Abbildung 3.3.8.: Wildtyp G. oxydans 621H, angezogen mit unterschiedlichen

\section{Rotationsgeschwindigkeiten über 8 h und Immunogold-markierter GOX1912.}

Die Abbildungen 3.3.8.a bis d zeigen TEM-Elektronenmikrograhien von G. oxydans 621H, die mit dem Antikörper gegen GOX1912 markiert wurden. Die in Kunstharz eingebetteten Zellkulturen wurden zuvor in Glycerol-Medium für $8 \mathrm{~h}$ bei 200 upm ( $\mathrm{a}$ und b), bzw. 50 upm (c und d) angezogen.

Vergleicht man die Quantität an markierter GOX1912 zwischen G. oxydans 621H angezogen über $8 \mathrm{~h}$ mit 200 upm und 50 upm (Abb. 3.3.8.), so ist eine schwache, kaum signifikant stärkere Markierung bei 200 upm zu erkennen ( $a$ und b). 

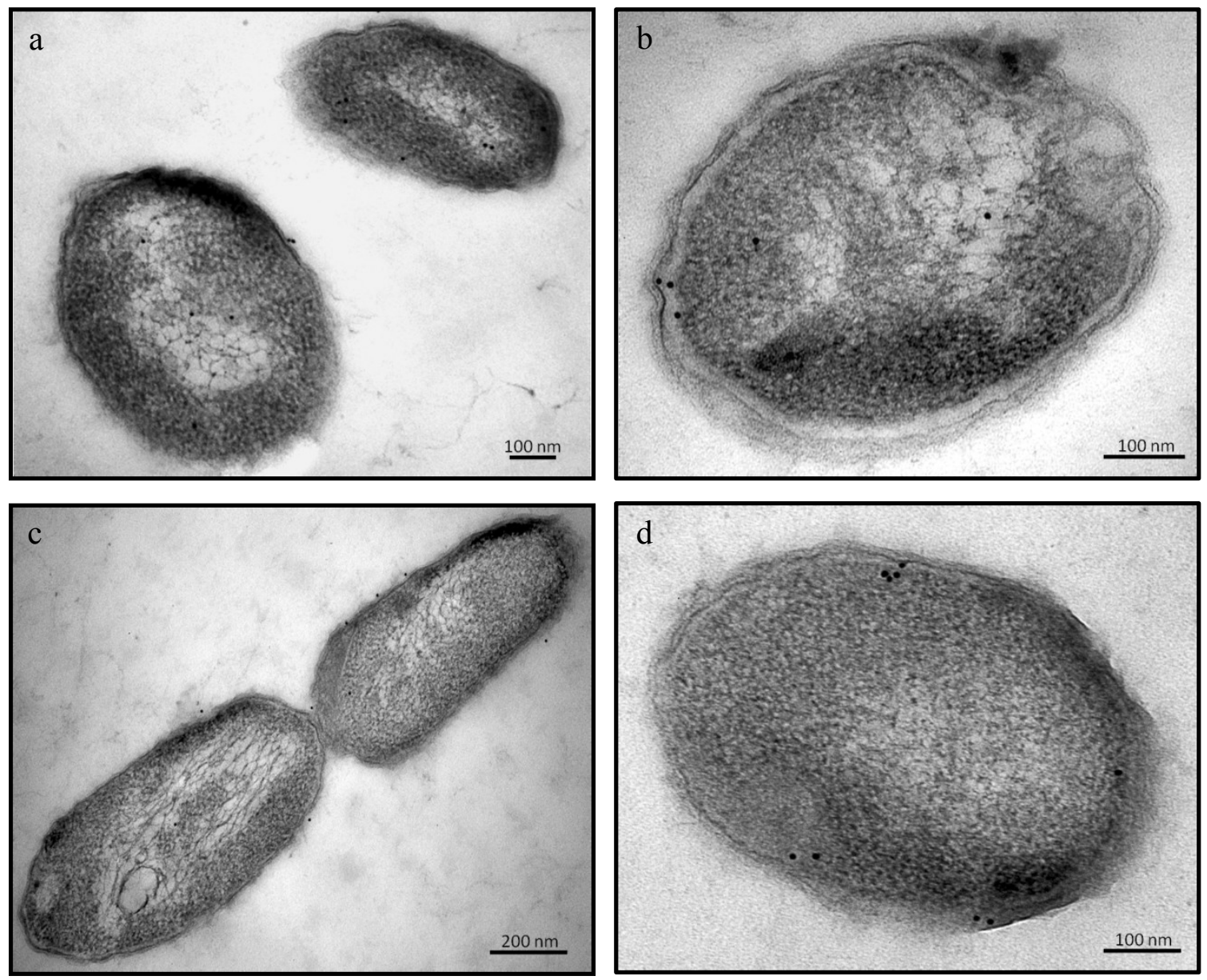

Abbildung 3.3.9.: Wildtyp G. oxydans 621H, angezogen mit unterschiedlichen

\section{Rotationsgeschwindigkeiten über 24 h und Immunogold-markierter GOX1912.}

Die Abbildungen 3.3.9.a bis d zeigen TEM-Elektronenmikrograhien von G. oxydans 621H, die mit dem Antikörper gegen GOX1912 markiert wurden. Die in Kunstharz eingebetteten Zellkulturen wurden zuvor in Standard Mannitol-Medium für $24 \mathrm{~h}$ bei 200 upm (a und b), bzw. 50 upm (c und d) angezogen.

Vergleicht man die Elektronenmikrographien in der Abb. 3.3.9 miteinander, so ist die Immunogold-Markierung der Zellen, die bei 50 upm angezogen wurden (c und d) etwas stärker als bei Zellen, die bei 200 upm angezogen wurden ( $a$ und $b$ ).

Insgesamt sind die Ergebnisse der Immunogold-Markierung von GOX1912 in G. oxydans $621 \mathrm{H}$ bei $200 \mathrm{upm}$ und 50 upm über $8 \mathrm{~h}$ und $24 \mathrm{~h}$ jeweils sehr ähnlich: Eine relativ schwache, aber deutliche Markierung der Zellperipherie. Die ImmunogoldMarkierung ist nach $24 \mathrm{~h}$ Wachstum in der stat. Wachstumsphase unter verringerter Sauerstoffkonzentration insgesamt am stärksten. Unter Standardbedingungen ist die Intensität der Markierung nach $8 \mathrm{~h}$ höher als nach $24 \mathrm{~h}$. 


\subsection{Das Monitoring membranständiger Dehydrogenasen mit fluoreszierenden membranständigen Fusionsproteinen}

Die Expression von membranständigen Dehydrogenasen während des Wachstums einer Kultur zu verfolgen, könnte bei der Entwicklung eines Produktionsstammes dienlich sein. Das Eruieren optimierter Anzuchtbedingungen oder die Überwachung des Produktionsstammes während der Fermentation wäre mit fluoreszierenden Enzymen möglich (VAN ROESSEL und BRAND, 2002). In diesem Kapitel wird die Eignung des auf einem Flavinmononukleotid basierenden fluoreszierenden Proteins (FbFP) für diese Aufgabe untersucht und die Ergebnisse der ersten translationalen Fusion mit einer membranständigen Dehydrogenase vorgestellt.

\subsubsection{Die Fusion eines auf Flavinmononukleotid basierenden fluoreszierenden Proteins mit einer membranständigen PQQ- abhängigen Dehydrogenase}

Studien zur Respiration von $G$. oxydans haben gezeigt, dass besonders während der exponentiellen Wachstumsphase der Sauerstoffverbrauch einer Kultur sehr hoch sein kann (SILBERBACH et al., 2003; HANKE et al., 2012). Um einen eventuellen Einfluss der Sauerstoffkonzentration auf die Intensität der Fluoreszenz auszuschließen, wurde für diesen Ansatz ein fluoreszierendes Protein gewählt, das unabhängig von der umgebenden Sauerstoffkonzentration fluoresziert. Das auf Flavinmononukleotid (FMN) basierende fluoreszierende Protein (FbFP), wie es in der Arbeit von DREPPER et al., (2010) beschrieben wurde, ist von der Fa. Evocatal mit dem Handelsnamen evoglowPp1 (egPp1) bezogen worden. Das Protein stammt ursprünglich aus Pseudomonas putida, wie Gluconobacter oxydans ein Vertreter aus der Abteilung der Proteobakterien. Neben dieser relativ nahen Verwandtschaft ist die geringe Größe von ca. 19 kDa ein weiterer Vorteil dieses Proteins gegenüber anderen fluoreszierenden Proteinen wie z. B. dem grün fluoreszierenden Protein (GFP). GFP stammt aus der Qualle Aequorea victoria, ist mit 26,9 $\mathrm{kDa}$ größer als das FbFP und benötigt darüber hinaus zur Entwicklung der Fluoreszenz Sauerstoff (MUKHERJEE et al, 2013).

Die membranständige PQQ-abhängige Dehydrogenase GOX1441 aus G. oxydans 621H besteht nur aus einer Untereinheit und weist mit 87,8 kDa eine im Vergleich zu anderen vergleichbaren Enzymen geringe Größe auf (PRUST et al., 2005), was die Arbeit mit 
diesem Enzym erleichtern könnte. Das Substratspektrum von GOX 1441 ist bis heute nicht bekannt (PETERS et al., 2013). In den folgenden Kapiteln werden zunächst die Ergebnisse der Expression von egPp1 in G. oxydans $621 \mathrm{H}$ beschrieben. Anschließend werden die Ergebnisse der translationalen Fusion von egPp1 und GOX1441 vorgestellt.

\subsubsection{Die Expression von evoglowPp1 in G. oxydans 621H}

Zunächst war die Frage zu klären, ob egPp1 in G. oxydans $621 \mathrm{H}$ exprimiert werden kann. Dafür wurde das Gen von dem Plasmid pGLOW-Pp1-stop von der Fa. Evocatal mit den Primern SK033fwd und SK034rev amplifiziert (Kap. 7.2). Das Agarosegel mit vier PCR-Ansätzen ist in Abb. 3.4.1. gezeigt.

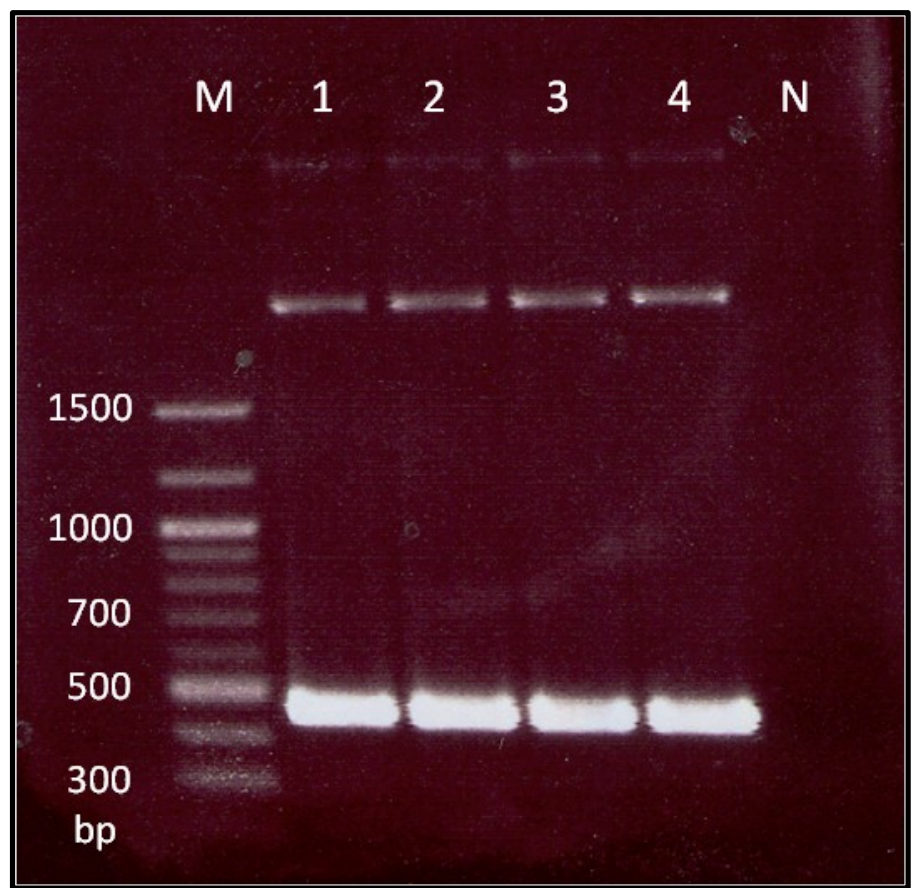

Abb. 3.4.1.: Ergebnis der Amplifikation der Fragmente für die OEPCR.

$1 \%$ iges Agarosegel mit aufgetrennten amplifizierten Fragmenten von evoglowPp1 $(2,5 \mu \mathrm{l})$ in den Spuren 1 bis 4. In der Spur $M$ sind $2 \mu 1$ der Quick-Load 100 bp DNA Ladder von NEB aufgetragen worden. In der Spur $\mathrm{N}$ ist die Negativkontrolle. Die erwartete Fragmentgröße betrug 462 bp.

Die erfolgreich amplifizierten evoglowPpl-Fragmente sind aufgereinigt und in die Plasmide pBBR1p264, pBBR1p384 und pBBR1p452 kloniert worden. Die Plasmide pBBR1p264-egPp1, pBBR1p384-egPp1 und pBBR1p452-egPp1 sind zunächst in E. coli DH5a transformiert worden. Die Abb. 3.4.2. zeigt das Ergebnis einer KoloniePCR mit positiven Klonen welche die Plasmide pBBR1p264-egPp1 und pBBR1p452egPpl enthalten, sowie einer Negativkontrolle und dem Plasmid pGlowPp1-stop als Positivkontrolle. Für die Kolonie-PCR wurden die Primer SK033fwd und Sk034rev verwendet. 


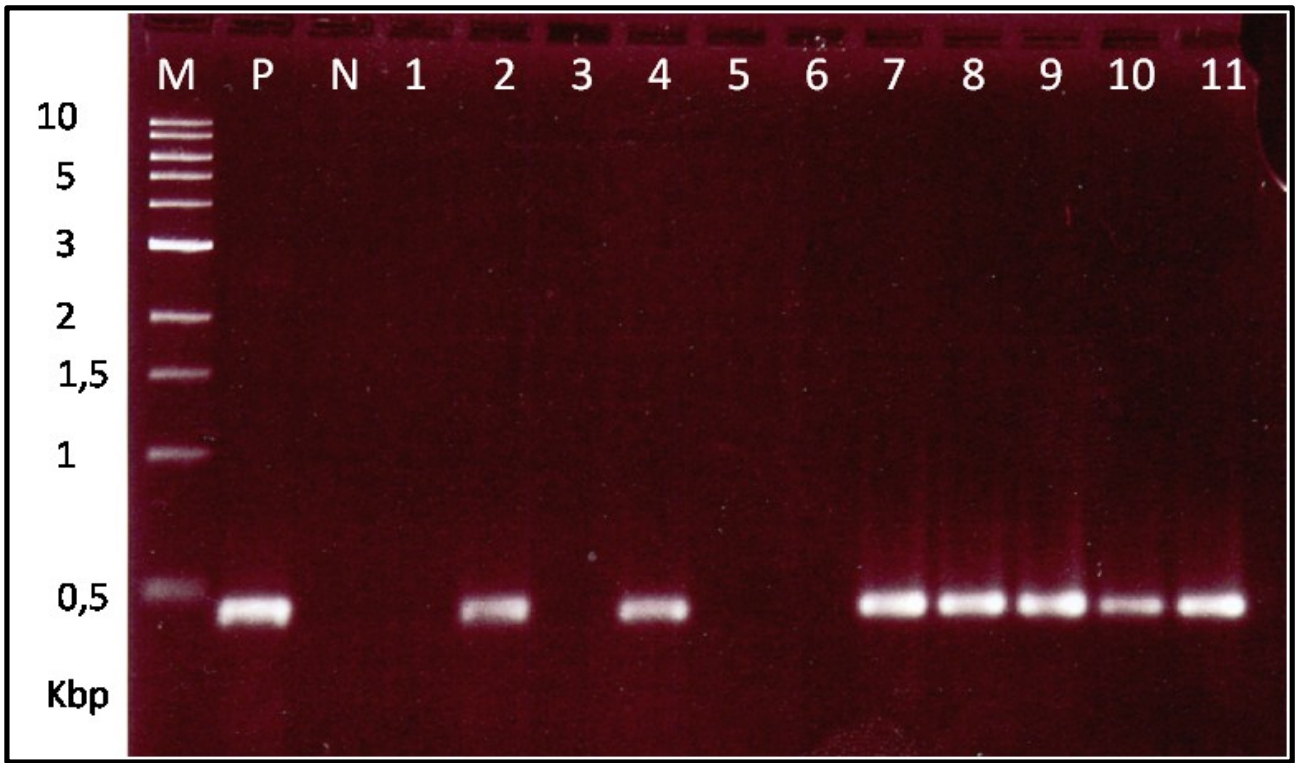

Abb. 3.4.2.: Ergebnis der Kolonie-PCR mit E. coli DH5a-Stämmen.

$1 \%$ iges Agarosegel mit jeweils $3 \mu \mathrm{l}$ aufgetragenen PCR-Produkten. (P) Positiv- und (N) Negativkontrolle. Spur 1 bis 6 E. coli DH5a pBBR1p452-egPp1, Spur 7 bis 11 E. coli DH5 $\alpha$ pBBR1p264-egPp1. M: $2 \mu 11$ kb DNA Ladder. Die zu erwartende Fragmentgröße betrug $462 \mathrm{bp}$.

Von positiven Klonen sind die Plasmide präpariert, und in G. oxydans $621 \mathrm{H}$ via Elektroporation transformiert worden. Die Abb. 3.4.3. zeigt beispielhaft das Ergebnis der Kolonie-PCR von G. oxydans pBBR1p384-egPp1-Stämmen, die alle positiv sind.

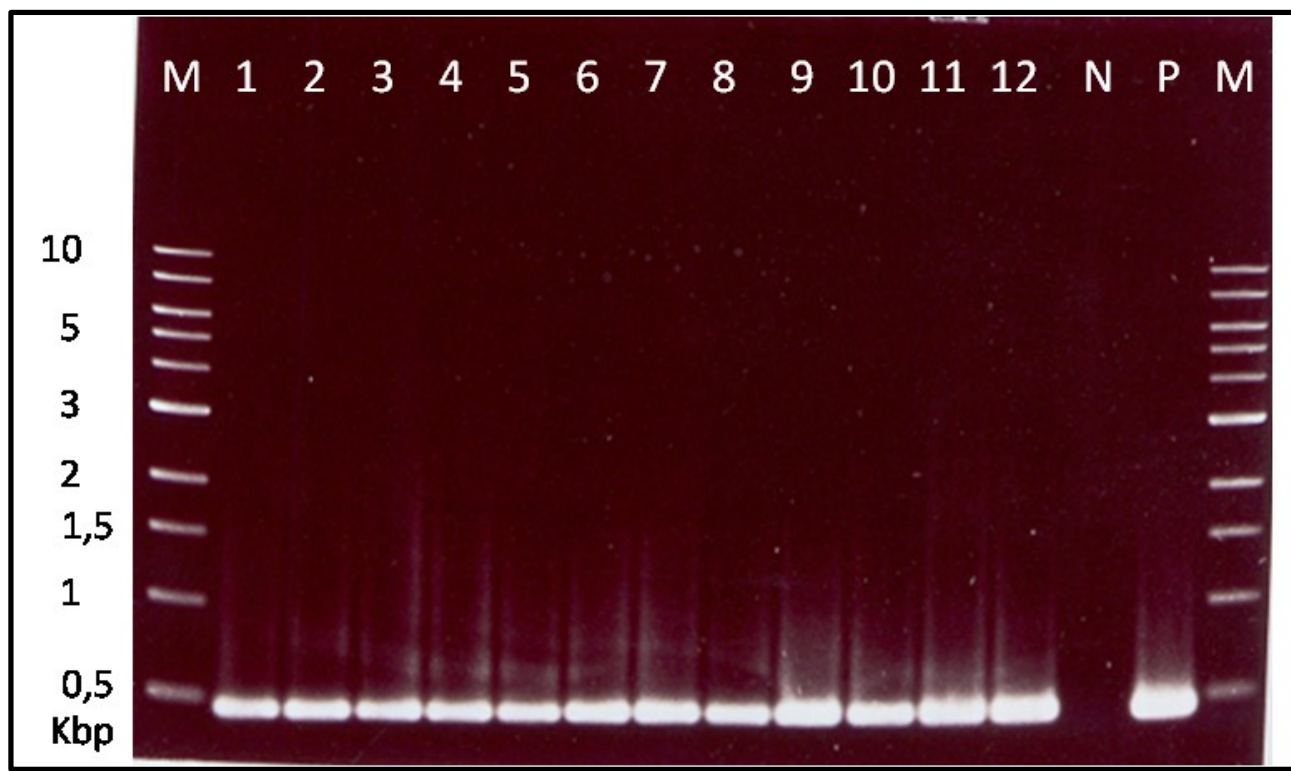

Abb. 3.4.3.: Ergebnis der Kolonie-PCR mit G. oxydans-Stämmen.

$1 \%$ iges Agarosegel mit jeweils $3 \mu \mathrm{l}$ aufgetragenen PCR-Produkten. (P) Positiv- und (N) Negativkontrolle. Spur 1 bis 12 via Elektroporation entstandene G. oxydans pBBR1p384egPp1-Stämme. M: $2 \mu 11 \mathrm{~kb}$ DNA Ladder. Die zu erwartende Fragmentgröße betrug $462 \mathrm{bp}$. 
Die Bereiche der Promotoren und des eingefügten Gens sind mit den Promotorspezifischen Vorwärts-Primern SK041fwd, SK047fwd und SK048fwd und dem Rückwärts-Primer SK046rev sequenziert worden. Die überprüften Stämme wurden hinsichtlich ihres Wachstums und ihrer Fluoreszenz untersucht.

\subsubsection{Das Wachstum evoglowPp1-exprimierender G. oxydans-Stämme}

Das Wachstum von G. oxydans pBBR1p264-egPp1, -p384-egPp1 und -p452-egPp1 wurde wie in Kap. 2.3.2 beschrieben unter Standardbedingungen untersucht. In der Abb. 3.4.4. sind die entsprechenden Wachstumskurven dargestellt. Die max. Wachstumsrate sowie die Verdopplungszeit wurden berechnet, wie es in Kap. 2.3.3 beschrieben worden ist.

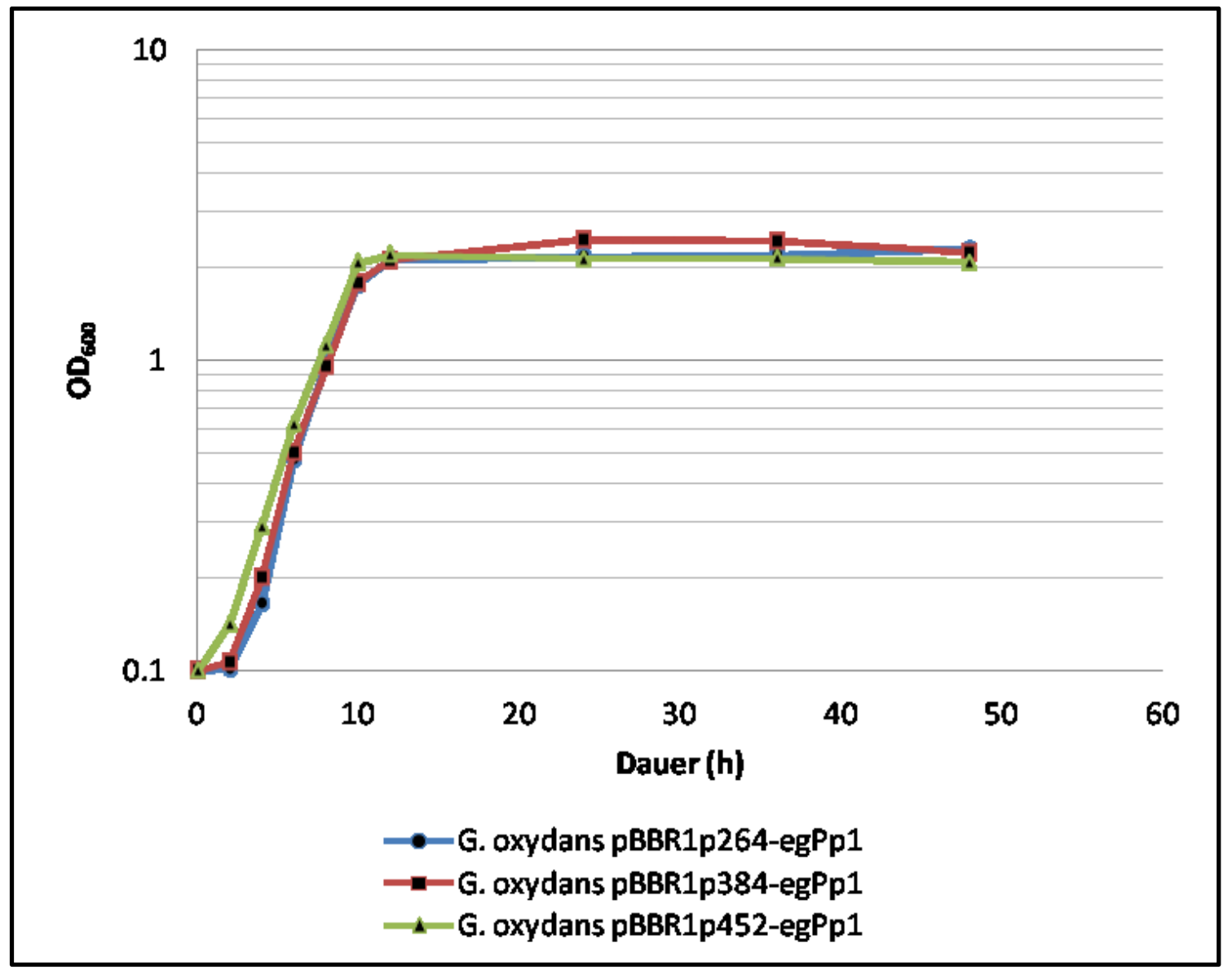

Abb. 3.4.4.: Das Wachstum evoglowPp1-exprimierender G. oxydans-Stämme.

Die Anzucht erfolgte bei $30^{\circ} \mathrm{C}$ und 200 upm in Standard Mannitol-Medium. Das Kulturvolumen entsprach $10 \%$ des Gefäßvolumens. Aus Vorkulturen wurden Hauptkulturen mit einer OD von 0,1 bei $600 \mathrm{~nm}$ angeimpft. 
Tabelle 3.4.1.: Wachstumsraten und Verdopplungszeiten evoglowPp1 exprimierender G. oxydans-Stämme und des Wildtyp G. oxydans $621 \mathrm{H}$.

\begin{tabular}{lccc}
\hline Organismus & max. Wachstumsrate & Verdopplungszeit & OD $_{\mathbf{6 0 0}}$ nach \\
& {$[\mathbf{1} / \mathbf{h}]$} & {$[\mathbf{h}]$} & $\mathbf{4 8} \mathbf{~ h}$ \\
\hline G. oxydans 621 H & 0,46 & 1,51 & 2,70 \\
G. oxydans p264-egPp1 & 0,45 & 1,56 & 2,27 \\
G. oxydans p384-egPp1 & 0,39 & 1,77 & 2,23 \\
G. oxydans p452-egPp1 & 0,34 & 2,06 & 2,08 \\
\hline
\end{tabular}

Aus der Abb. 3.4.4. und der Tabelle 3.4.1. geht hervor, dass die max. Wachstumsraten ähnlich der max. erreichten $\mathrm{OD}_{600}$ nach $48 \mathrm{~h}$ in der Reihenfolge G. oxydans p264egPp1, p384-egPp1 und p452-egPp1 sinkt und damit zum Teil deutlich niedriger ist, als die des Wildtyps unter gleichen Bedingungen. Die Verdopplungszeiten steigen dementsprechend an.

\subsubsection{Die Fluoreszenz evoglowPp1-exprimierender G. oxydans-Stämme}

Die Fluoreszenz der drei egPp1 exprimierenden G. oxydans-Stämme wurde wie in Kap. 2.6.2 beschrieben untersucht. In der Abb. 3.4.5. sind Aufnahmen bei einer $\mathrm{OD}_{600}$ von 0,2 (linke Spalte, Abb. a, c und e) und $\mathrm{OD}_{600}$ 0,5 (rechte Spalte, Abb. b, d und f) der Stämme G. oxydans pBBR1p264-egPp1, pBBR1p384-egPp1 sowie pBBR1p452-egPp1 zusammengefasst. 

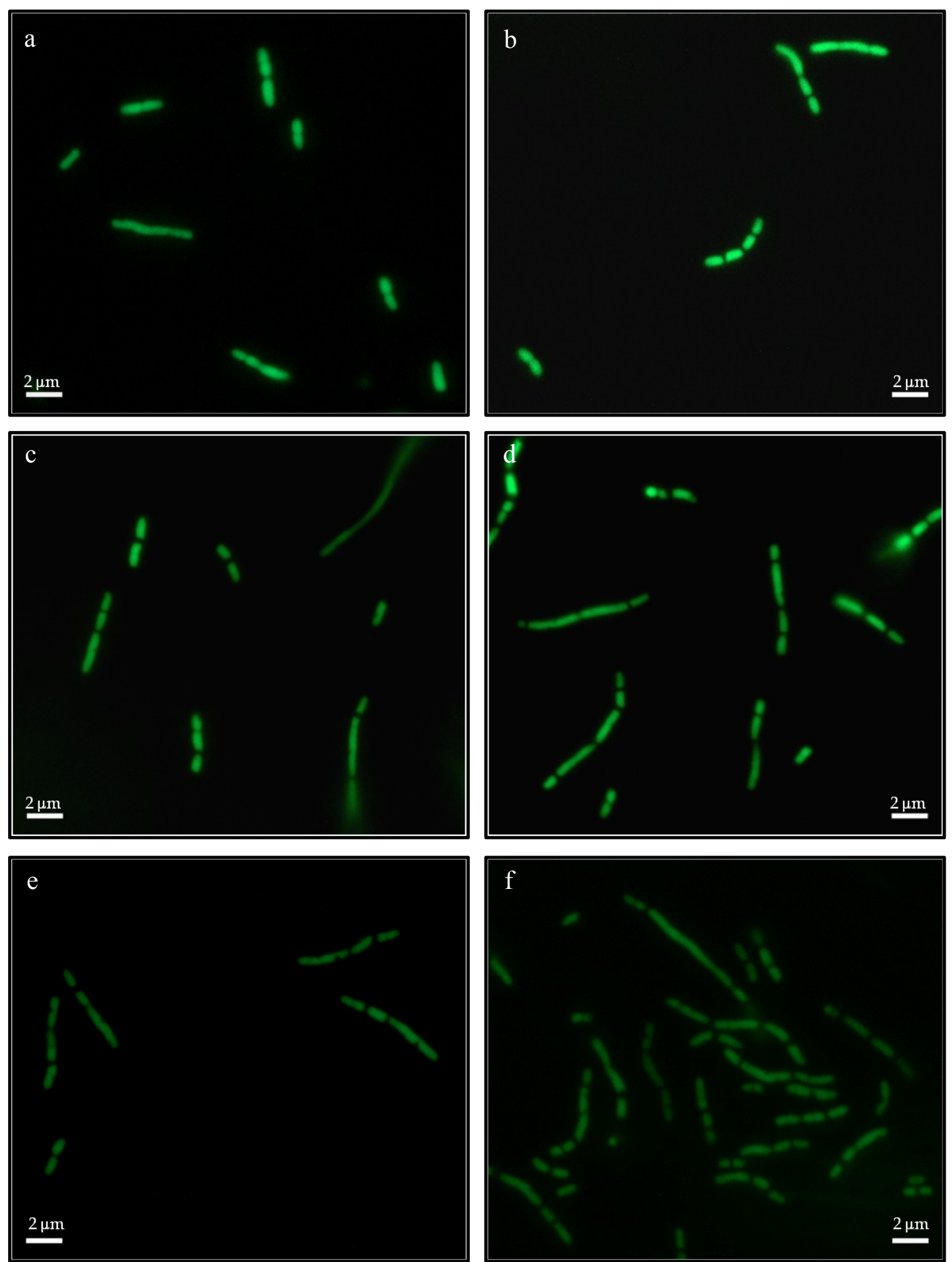

\section{Abb. 3.4.5.: Fluoreszenz evoglowPp1-exprimierender G. oxydans-Stämme.}

Epifluoreszenzmikroskopische Aufnahmen egPp1-exprimierender G. oxydans-Stämme. Die Belichtungszeit betrug jeweils $2 \mathrm{~s}$. Die Bilder wurden nachbearbeitet, um die unter dem Mikroskop gemachten Beobachtungen optimal wiederzugeben. Die Stämme sind G. oxydans pBBR1p264-egPp1 bei $\mathrm{OD}_{600} 0,2$ (a) und 0,5 (b), pBBR1p384-egPp1 bei $\mathrm{OD}_{600} 0,2$ (c) und 0,5 (d) und pBBR1p452-egPp1 bei $\mathrm{OD}_{600} 0,2$ (e) und 0,5 (f). 
Gesetzt den Fall, dass die Stärke der Fluoreszenz dem Ausmaß an exprimiertem egPp1 entspricht, ist die Expression unter der Kontrolle der Promotoren p264 und p384 ähnlich. Unter dem Mikroskop betrachtet erschien die Fluoreszenz im Falle des p264Promotors etwas stärker und stabiler. Die Fluoreszenz des Stammes G. oxydans pBBR1p452-egPp1 war deutlich schwächer und schneller ausgeblichen als mit den anderen beiden Stämmen. Darüber hinaus ist die Fluoreszenz am Anfang und in mitten der exp. Phase im Falle der Expression von egPp1 unter dem Einfluss der Promotoren p264 und p452 annähernd gleich stark. Unter dem Einfluss des Promotors p384 scheint die Expression im Verlauf der exp. Phase zuzunehmen.

\subsubsection{Die Konstruktion des Fusionsproteins aus GOX1441 und evoglowPp1 und dessen Expression in G. oxydans 621H}

Die mutmaßlich membranständige PQQ-abhängige Dehydrogenase GOX1441 besitzt N-terminal ein Signalpeptid, das über den Transportweg und die Lokalisation des Proteins innerhalb der Zelle und dessen Lokalisation in der Membran entscheidet. Um den korrekten Einbau des Fusionsproteins in die Cytoplasmamembran nicht zu unterbinden, sollte egPp1 den C-terminalen Teil des Fusionsproteins bilden. Für die Overlap-extension-PCR (OEPCR) wurde das Gen evoglowPp1-stop von dem Plasmid pGLOW-Pp1 von der Fa. Evocatal mit den Primern SK049fwd und SK050rev amplifiziert. Das Gen gox1441 wurde mit präparierter DNA von G. oxydans $621 \mathrm{H}$ als Matrize mit den Primern SK051fwd und SK051rev amplifiziert. Ein Agarosegel mit den beiden Amplifikaten ist in Abb. 3.4.6. gezeigt. 


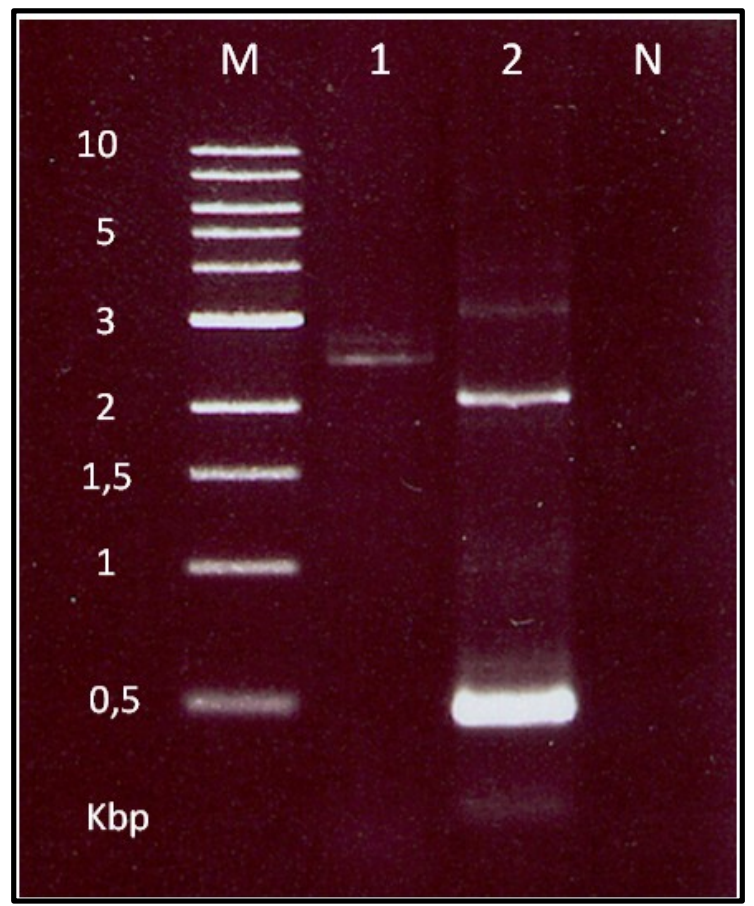

Abb. 3.4.6.: Ergebnis der Amplifikation der Fragmente für die OEPCR.

Die Abb. zeigt die in einem 1 \%igen Agarosegel aufgetrennten amplifizierten Fragmente von gox1441 (5 $\mu 1)$ in Spur 1 und evoglowPp1 $(2 \mu 1)$ in Spur 2. In der Spur M sind $2 \mu 1$ der QuickLoad $1 \mathrm{~kb}$ DNA Ladder von NEB aufgetragen worden. Die erwarteten Fragmentgrößen waren 2457 bp für gox1441 und 486 bp für evoglowPp1.

Die aufgereinigten Fragmente wurden in einer zweiten OEPCR-Reaktion fusioniert. Das Fusionsprodukt ist anschließend mit den Primern SK049fwd und SK052rev amplifiziert worden. Das Ergebnis ist in Abb. 3.4.7. gezeigt.

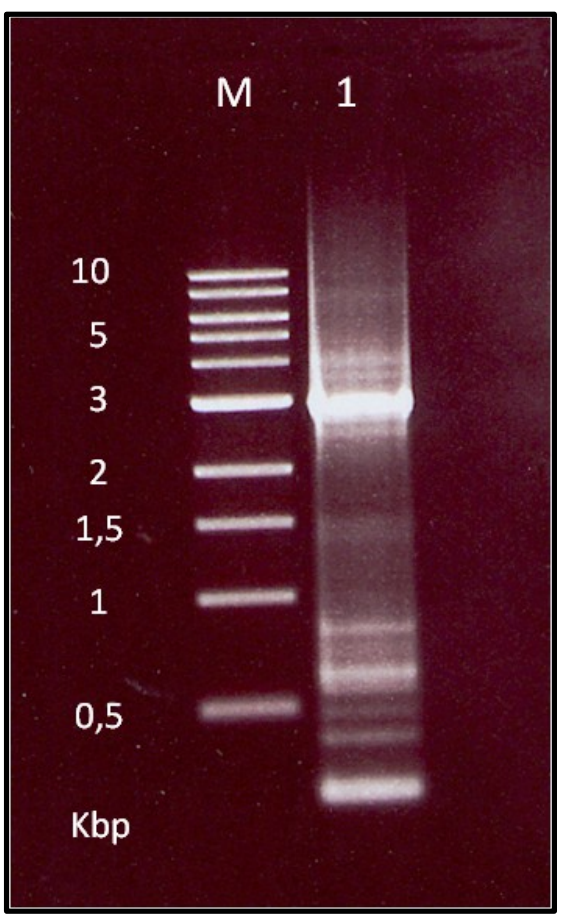

\section{Abb. 3.4.7.: Ergebnis der Amplifikation des OEPCR- Fusionsprodukts.}

Die Abb. zeigt das in einem $1 \%$ igen Agarosegel aufgetrennte amplifizierte Fusionsprodukt von gox1441 und evoglowPp1 (3 $\mu 1)$ in Spur 1. In der Spur M sind $2 \mu 1$ der Quick-Load 1 kb DNA Ladder von NEB aufgetragen worden. Die erwartete Fragmentgröße betrug 2943 bp.

Das aufgereinigte amplifizierte Fusionsprodukt wurde in die Plasmide pBBR1p264, pBBR1p384 und pBBR1p452 kloniert und diese anschließend in E. coli DH5 $\alpha$ transformiert. Die erhaltenen Transformanten wurden in einer Kolonie-PCR-Analyse 
auf die richtigen Plasmide hin untersucht. Die für diese Analyse benutzen Primer sind zusammen mit den zu erwarteten PCR-Produkten in Tab. 3.4.2. aufgelistet, die Vorwärts-Primer sind spezifisch für die jeweiligen Promotor-Regionen.

Tab. 3.4.2.: Primer für die Kolonie-PCR mit Fusionsprotein exprimierenden Stämmen

\begin{tabular}{lccc}
\hline Plasmid & $\begin{array}{c}\text { Vorwärts- } \\
\text { Primer }\end{array}$ & Rückwärts-Primer & $\begin{array}{c}\text { Zu erwartendes } \\
\text { PCR-Produkt }\end{array}$ \\
\hline $\begin{array}{l}\text { pBBR1p264- } \\
\text { gox1441-egPp1 } \\
\text { pBBR1p384- }\end{array}$ & SK041fwd & SK046rev & $3046 \mathrm{bp}$ \\
$\begin{array}{l}\text { gox1441-egPp1 } \\
\text { pBBR1p452- }\end{array}$ & SK047fwd & SK046rev & $3059 \mathrm{bp}$ \\
gox1441-egPp1 & SK048fwd & SK046rev & $3074 \mathrm{bp}$ \\
\hline
\end{tabular}

Die Abb. 3.4.8. zeigt das Agarosegel, in dem u. a. der letztendlich benutzte Klon mit dem Plasmid pBBR1p452-gox1441-egPp1 dargestellt ist (Spur 5).

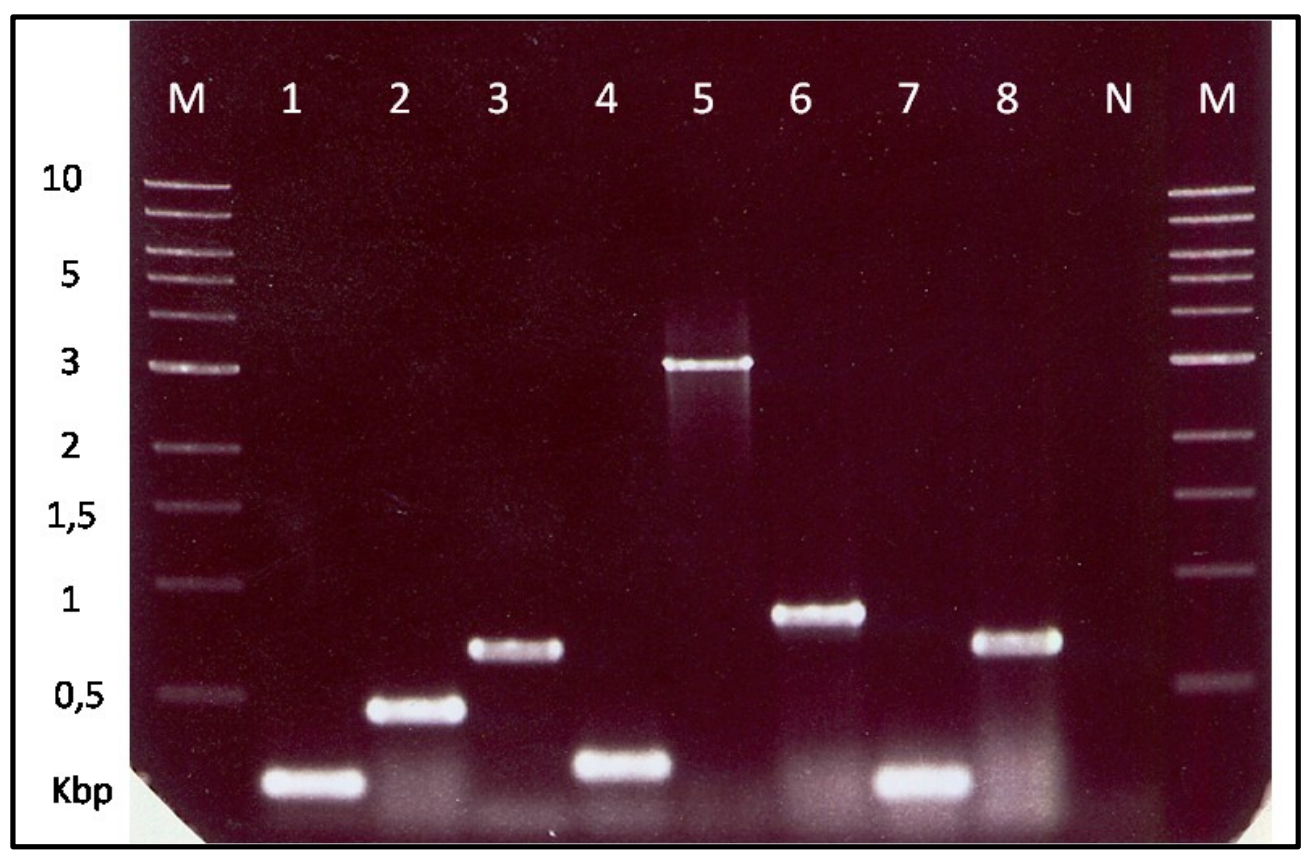

Abb. 3.4.8.: Ergebnis der Kolonie-PCR mit E. coli DH5a-Stämmen.

$1 \%$ iges Agarosegel mit jeweils $3 \mu$ l aufgetragenen Kolonie-PCR-Produkten. Spur 1 bis 8: Mit amplifiziertem Fusionsprodukt transformierte E. coli DH5 $\alpha$. Spur 9: Negativkontrolle. Spuren M: $2 \mu 1$ der Quick-Load 1 kb DNA Ladder von NEB. Die erwartete Fragmentgröße betrug $3074 \mathrm{bp}$. 
Plasmide, die den Erwartungen entsprachen wurden per Elektroporation in G. oxydans $621 \mathrm{H}$ transformiert und die daraus hervorgegangenen Stämme mittels Kolonie-PCR überprüft. I. d. R. entsprachen die Agarosegele der in Abb. 3.4.9. dargestellten KoloniePCR des Stammes G. oxydans pBBR1p452-GOX1441-egPp1.

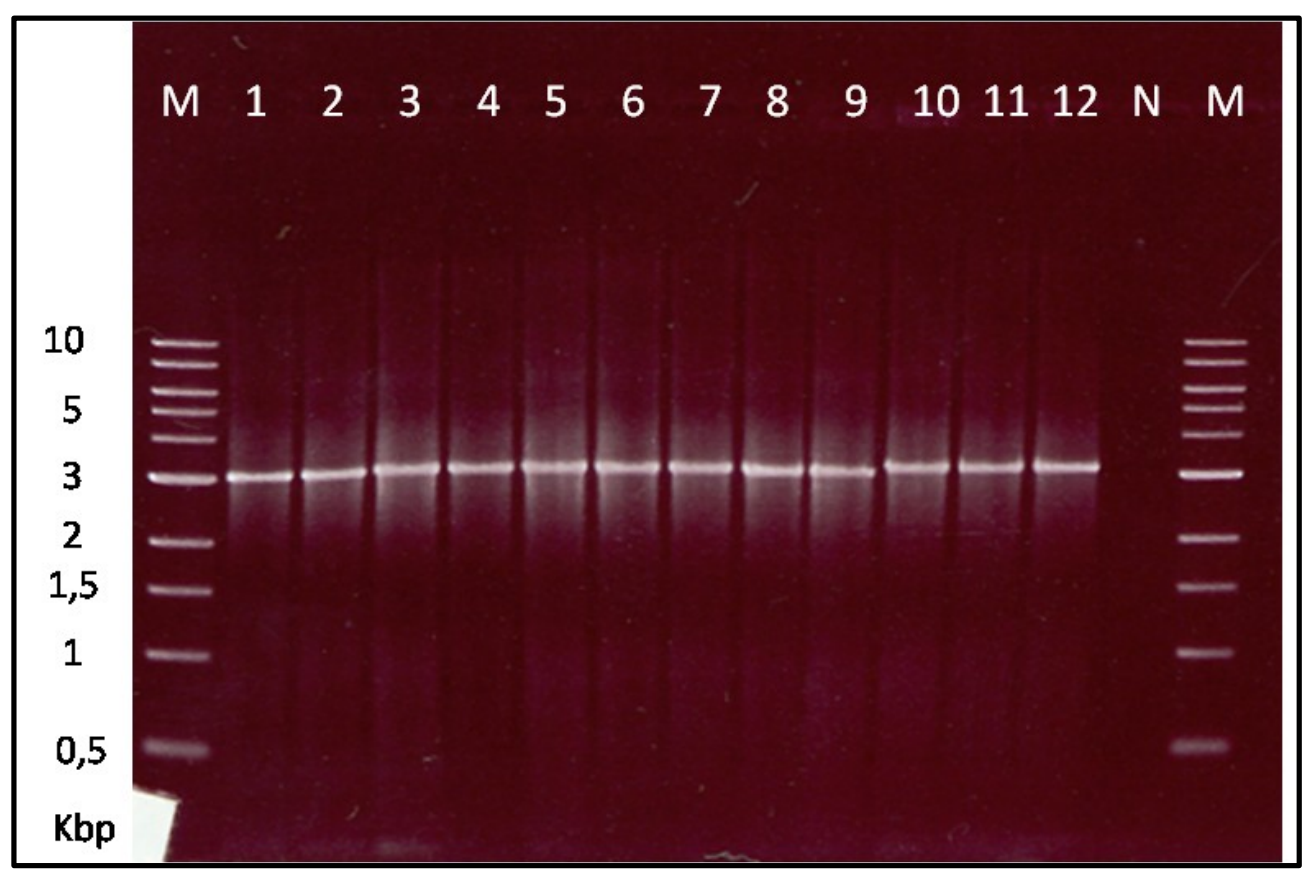

Abb. 3.4.9.: Ergebnis der Kolonie-PCR mit G. oxydans-Stämmen.

$1 \%$ iges Agarosegel mit jeweils $3 \mu \mathrm{l}$ aufgetragenen Kolonie-PCR-Produkten. Spur 1 bis 12 via Elektroporation entstandene G. oxydans pBBR1p452-GOX1441-egPp1-Stämme. Spur N: Negativkontrolle. Spuren M: $2 \mu \mathrm{l}$ der Quick-Load 1 kb DNA Ladder von NEB. Die erwartete Fragmentgröße betrug 3074 bp.

Die Plasmide sind mit Hilfe der Promotor-spezifischen Vorwärts-Primer SK041fwd, SK047fwd und SK048fwd (Tab. 3.4.2.) sowie den Primern SK042fwd bis SK045fwd sequenziert worden. Die Sequenzen aller benutzten Primer sind im Anhang in Kap. 7.2 aufgelistet. Nachdem die Bereiche der Promotoren und des eingefügten Gens per Sequenzierung überprüft worden sind, ist das Wachstum der entstandenen Stämme untersucht worden und es wurden fluoreszenzmikroskopische Aufnahmen im Verlauf der exp. Phase gemacht. 


\subsubsection{Das Wachstum GOX1441-egPp1-exprimierender G. oxydans-Stämme}

Das Wachstum von G. oxydans p264-GOX1441-egPp1, - p384-GOX1441-egPp1 und p452-GOX1441-egPp1 wurde unter Standardbedingungen, wie es in Kap. 2.3.2 beschrieben ist, untersucht. In der Abb. 3.4.10. sind die entsprechenden Wachstumskurven dargestellt. In der Tabelle 3.4.3. sind die max. Wachstumsrate sowie die Verdopplungszeiten (Kap. 2.3.3) im Vergleich mit dem Wildtyp zusammengefasst.

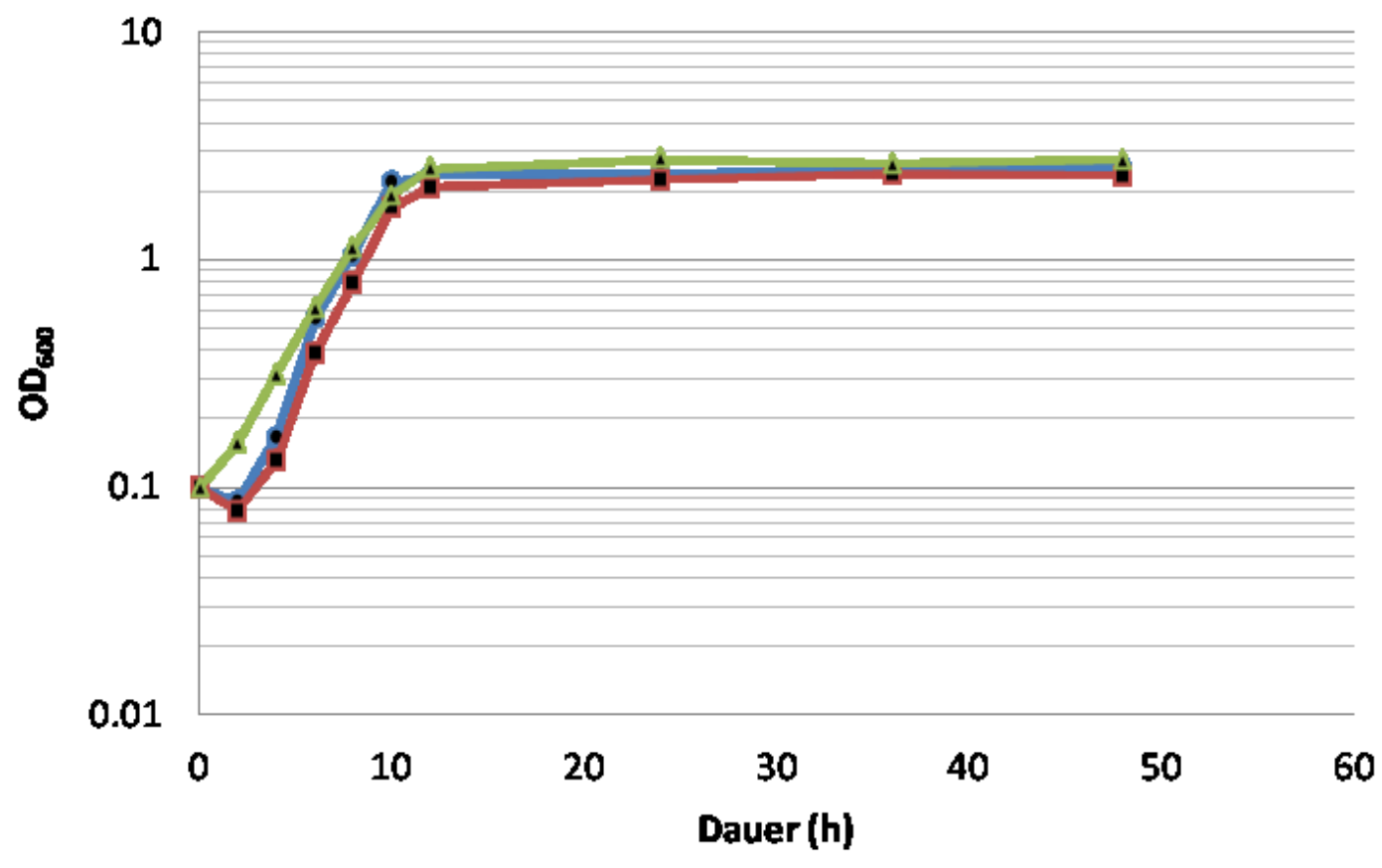

G. oxydans pBBR1p264-gox1441-egPp1

G. oxydans pBBR1p384-gox1441-egPp1

G. oxydans pBBR1p452-gox1441-egPp1

Abb. 3.4.10.: Das Wachstum GOX1441-evoglowPp1-exprimierender G. oxydansStämme.

Die Anzucht erfolgte bei $30^{\circ} \mathrm{C}$ und 200 upm in Standard Mannitol-Medium. Das Kulturvolumen entsprach $10 \%$ des Gefäßvolumens. Aus Vorkulturen wurden Hauptkulturen mit einer OD von 0,1 bei $600 \mathrm{~nm}$ angeimpft. 
Tabelle 3.4.3.: Wachstumsraten und Verdopplungszeiten GOX1441-evoglowPp1 exprimierender G. oxydans-Stämme und des Wildtyp G. oxydans 621H.

\begin{tabular}{lccc}
\hline Organismus & max. Wachstumsrate & Verdopplungszeit & OD $_{\mathbf{6 0 0}}$ nach \\
& {$[\mathbf{1} / \mathbf{h}]$} & {$[\mathbf{h}]$} & $\mathbf{4 8} \mathbf{~ h}$ \\
\hline $\begin{array}{l}\text { G. } \text { oxydans 621 H } \\
\text { G. oxydans }\end{array}$ & 0,46 & 1,51 & 2,70 \\
p264-GOX1441-egPp1 & 0,43 & 1,61 & 2,56 \\
$\begin{array}{l}\text { G. } \text { oxydans } \\
\text { p384-GOX1441-egPp1 }\end{array}$ & 0,43 & & \\
$\begin{array}{l}\text { G. } \text { oxydans } \\
\text { p452-GOX1441-egPp1 }\end{array}$ & 0,32 & 1,62 & 2,33 \\
\hline
\end{tabular}

Aus der Wachstumskurve in Abb. 3.4.10. und der Tabelle 3.4.3. geht hervor, dass die erreichten $\mathrm{OD}_{600}$ mit 2,55 für G. oxydans pBBR1p264-GOX1441-egPp1 und 2,33 für p384-GOX1441-egPp1 unter der $\mathrm{OD}_{600}$ des Wildtyps G. oxydans $621 \mathrm{H}$ liegen, der unter den gleichen Bedingungen eine $\mathrm{OD}_{600}$ von 2,70 erreicht. Im Falle des Stammes, der GOX1441-egPp1 unter der Kontrolle des p452-Promotors exprimiert ist die nach $48 \mathrm{~h}$ erreichte $\mathrm{OD}_{600}$ mit 2,73 etwas höher als die des Wildtyps. Die max. Wachstumsraten sinken in der Reihenfolge p264, p384 und p452. Die Verdopplungszeiten verhalten sich dementsprechend, der Wildtyp wächst etwas schneller, als die GOX1441-evoglowPp1exprimierenden Stämme. Die $\mathrm{OD}_{600}$ nach $48 \mathrm{~h}$ ist im Falle von p452 mit der des Wildtyps vergleichbar, die beiden anderen Stämme erreichen nur eine geringere Zelldichte.

\subsubsection{Die Fluoreszenz GOX1441-egPp1-exprimierender G. oxydans-Stämme}

Die Fluoreszenz der drei GOX1441-evoglowPp1 exprimierenden G. oxydans-Stämme wurde wie in Kap. 2.6.2 beschrieben untersucht. In der Abb. 3.4.11. sind Aufnahmen bei einer $\mathrm{OD}_{600}$ von 0,2 (links) und $\mathrm{OD}_{600}$ 0,5 (rechts) von $G$. oxydans mit den Plasmiden pBBR1p264-gox1441-egPp1 (a und b), pBBR1p384-gox1441-egPp1 (c und d), sowie pBBR1p452-gox1441-egPpl (e und f) zusammengefasst. 

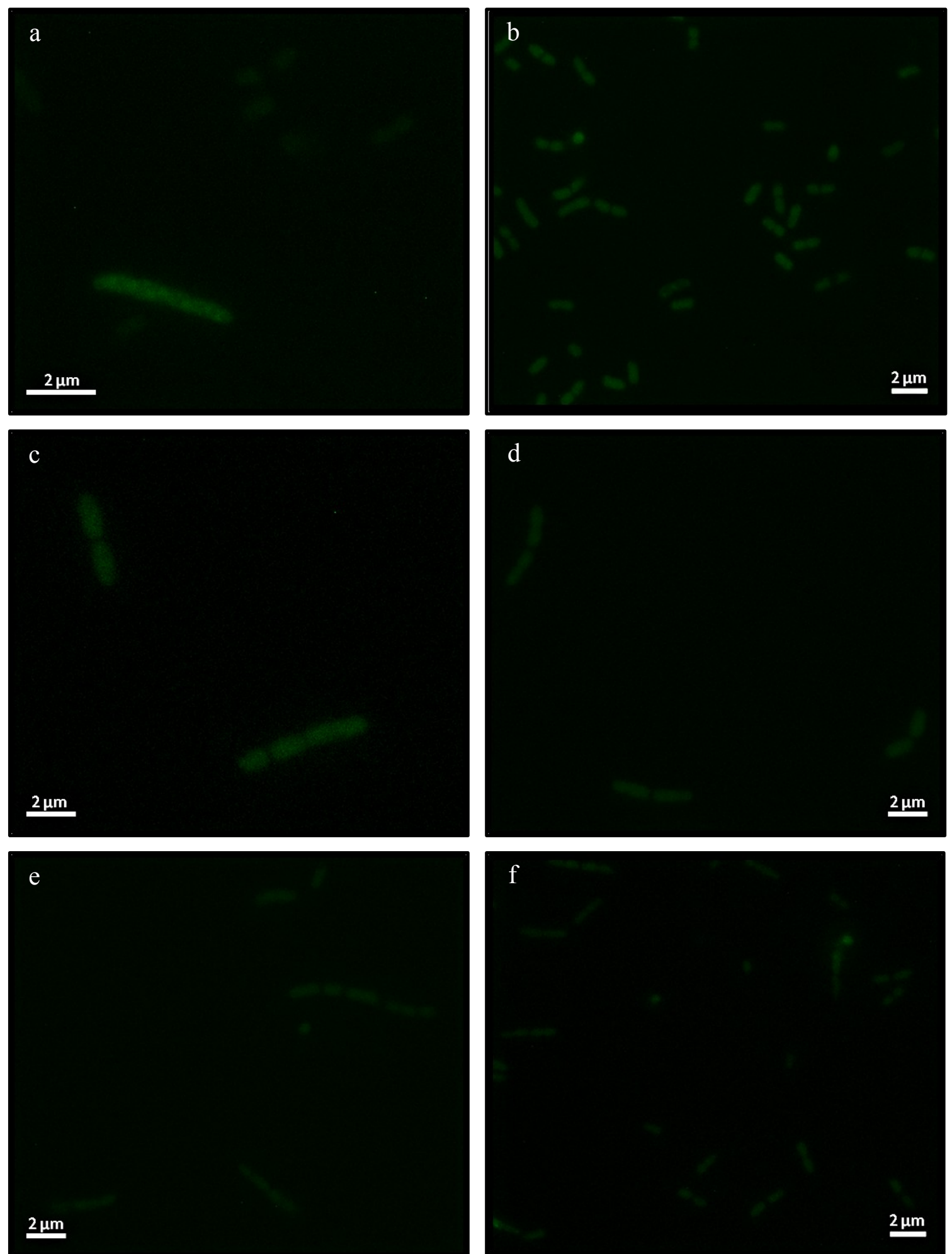

Abb. 3.4.11.: GOX1441-evoglowPp1-exprimierende G. oxydans-Stämme

Epifluoreszenzmikroskopische Aufnahmen GOX1441-evoglowPp1-exprimierender G. oxydansStämme. Die Belichtungszeit betrug jeweils $2 \mathrm{~s}$. Die Bilder wurden nachbearbeitet, um die unter dem Mikroskop gemachten Beobachtungen optimal wiederzugeben. Die Stämme sind G. oxydans pBBR1p264-gox1441-egPp1 bei OD $_{600}$ 0,2 (a) und 0,5 (b), G. oxydans pBBR1p384-gox1441-egPp1 bei $\mathrm{OD}_{600} 0,2$ (c) und 0,5 (d) und G. oxydans pBBR1p452- gox1441-egPp1 bei $\mathrm{OD}_{600} 0,2$ (e) und 0,5 (f). 
Die Fluoreszenz dieser Stämme war durchgehend sehr schwach und umfasste die ganze Zelle. Die Fluoreszenz war tendenziell bei einer $\mathrm{OD}_{600}$ von 0,5 etwas stärker. Einschlusskörper waren nicht zu erkennen.

\subsection{Wachstumsraten und Verdopplungszeiten}

\subsubsection{Wachstumsraten und Verdopplungszeiten des Wildtyp G. oxydans $621 \mathrm{H}$}

In der Tabelle 3.5.1. sind die maximalen Wachstumsraten und Verdopplungszeiten vom Wildtyp G. oxydans $621 \mathrm{H}$ zusammengefasst, sie wurden aus den Messdaten für die Wachstumskurven berechnet, wie es in Kap. 2.3.3 beschrieben ist.

Tabelle 3.5.1.: Wachstumsraten und Verdopplungszeiten von G. oxydans 621H

\begin{tabular}{|c|c|c|}
\hline $\begin{array}{l}\text { Organismus und } \\
\text { Wachstumsbedinungen }\end{array}$ & $\begin{array}{l}\text { Wachstumsrate } \boldsymbol{\mu} \\
\text { [Verdopplung/h] }\end{array}$ & $\begin{array}{c}\text { Verdopplungszeit } t_{d} \\
{[1 / h]}\end{array}$ \\
\hline $\begin{array}{l}\text { G. oxydans } 621 \mathrm{H} \\
\text { Standardbedingungen }\end{array}$ & 0,46 & 1,51 \\
\hline $\begin{array}{l}\text { G. oxydans } 621 \mathrm{H} \\
\text { Sauerstoffmangel }\end{array}$ & 0,18 & 3.77 \\
\hline $\begin{array}{l}\text { G. oxydans } 621 \mathrm{H} \\
\text { Standard mit Glycerin }\end{array}$ & 0,43 & 1,61 \\
\hline $\begin{array}{l}\text { G. oxydans } 621 \mathrm{H} \\
0.1 \mathrm{M} \text { Glycerin }\end{array}$ & 0,34 & 2,03 \\
\hline $\begin{array}{l}\text { G. oxydans } 621 \mathrm{H} \\
0.5 \mathrm{M} \text { Glycerin }\end{array}$ & 0,25 & 2,77 \\
\hline $\begin{array}{l}\text { G. oxydans } 621 \mathrm{H} \\
1.0 \mathrm{M} \text { Glycerin }\end{array}$ & 0,23 & 2,99 \\
\hline $\begin{array}{l}\text { G. oxydans } 621 \mathrm{H} \\
0.1 \mathrm{M} \text { Mannitol }\end{array}$ & 0,26 & 1,76 \\
\hline $\begin{array}{l}\text { G. oxydans } 621 \mathrm{H} \\
0.5 \mathrm{M} \text { Mannitol }\end{array}$ & 0,43 & 1,60 \\
\hline $\begin{array}{l}\text { G. oxydans } 621 \mathrm{H} \\
\text { 1.0 M Mannitol }\end{array}$ & 0,59 & 1,17 \\
\hline
\end{tabular}




\subsubsection{Wachstumsraten und Verdopplungszeiten genetisch veränderter Stämme von G. oxydans $621 \mathrm{H}$}

In der Tab. 3.5.2. sind die maximalen Wachstumsraten und Verdopplungszeiten genetisch veränderter Stämme von G. oxydans $621 \mathrm{H}$ zusammengefasst, sie wurden aus den Messdaten für die Wachstumskurven berechnet, wie es in Kap. 2.3.3 beschrieben ist.

Tabelle 3.5.2.: Wachstumsraten und Verdopplungszeiten genetisch veränderter Stämme von G. oxydans $621 \mathrm{H}$

\begin{tabular}{|c|c|c|}
\hline $\begin{array}{l}\text { Organismus und } \\
\text { Wachstumsbedinungen }\end{array}$ & $\begin{array}{l}\text { Wachstumsrate } \mu \\
\text { [Verdopplung/h] }\end{array}$ & $\begin{array}{c}\text { Verdopplungszeit } t_{d} \\
{[1 / h]}\end{array}$ \\
\hline $\begin{array}{l}\text { G. oxydans } 621 \mathrm{H} \\
\text { Standardbedingungen }\end{array}$ & 0,46 & 1,51 \\
\hline $\begin{array}{l}\text { G. oxydans } \\
\text { p264-egPp1 }\end{array}$ & 0,46 & 1,56 \\
\hline $\begin{array}{l}\text { G. oxydans } \\
\text { p384-egPp1 }\end{array}$ & 0,39 & 1,77 \\
\hline $\begin{array}{l}\text { G. oxydans } \\
\text { p452-egPp1 }\end{array}$ & 0,35 & 2,06 \\
\hline $\begin{array}{l}\text { G. oxydans } \\
\text { p264-GOX1441-egPp1 }\end{array}$ & 0,43 & 1,61 \\
\hline $\begin{array}{l}\text { G. oxydans } \\
\text { p384-GOX1441-egPp1 }\end{array}$ & 0,43 & 1,62 \\
\hline $\begin{array}{l}\text { G. oxydans } \\
\text { p452-GOX1441-egPp1 }\end{array}$ & 0,32 & 2,18 \\
\hline G. oxydans $\Delta$ gox 1441 & 0,35 & 2,00 \\
\hline $\begin{array}{l}\text { G. oxydans } \\
\text { Dgox1911-1914 }\end{array}$ & 0,27 & 2,58 \\
\hline $\begin{array}{l}\text { G. oxydans } \\
\text { Agox1911-1914 } \mathrm{O}_{2} \text {-Mangel }\end{array}$ & 0,18 & 3,97 \\
\hline
\end{tabular}




\section{Diskussion}

In früheren Arbeiten zur Zytologie von Gluconobacter wurde das Vorkommen von intracytoplasmatischen Membranen (ICM) an den Zellpolen von G. oxydans festgestellt, wenn die Zellkulturen mit Glycerol angezogen wurden und sie sich in der stationären Wachstumsphase befanden (CLAUS et al., 1975). Zeitgleich mit dem Auftreten der ICM wurde eine erhöhte Respirationsrate und eine gesteigerte Produktionsrate von Dihydroxyaceton, dem Oxidationsprodukt von Glycerol durch membranständige Dehydrogenasen, gemessen. Beides wurde dem gesteigerten Umsatz des Glycerol als Folge der ICM-Bildung zugeschrieben. Es wäre durchaus denkbar, dass die dadurch vergrößerte Membranoberfläche mehr enzymatischen Systemen Platz bieten könnte. $\mathrm{Ob}$ dieser Effekt für die biotechnologische Anwendung von Nutzen ist und $\mathrm{zu}$ einem höheren Umsatz von Substraten zu wirtschaftlich interessanten Produkten führen könnte steht im Mittelpunkt dieser Diskussion. Um das Potential der unvollständigen Oxidationen durch G. oxydans für die Biotechnologie voll auszuschöpfen, sollte man sich nicht allein darauf verlassen, die optimalen Fermentationsbedingungen empirisch $\mathrm{zu}$ ermitteln. Eine Erweiterung des Grundlagenwissens über die Entstehung und Entwicklung der ICM in G. oxydans, sowie ihre Rolle als Standort für membranständige Dehydrogenasen könnte die Fermentationsprozesse in Zukunft effektiver und wirtschaftlicher gestalten.

Eine Möglichkeit, um die Expression und Organisation von Proteinen an den Membranen zu untersuchen, ist deren Lokalisation mittels Immunogold-Markierung an Ultradünnschnitten von in Kunstharz eingebetteten Zellen (WREDE et al., 2013). Die Herstellung und die Qualität von IgG-Antikörpern gegen Enzyme, die an den unvollständigen Oxidationen beteiligt sind, ist zunächst Gegenstand der Diskussion. Anschließend wird sich der Frage gewidmet, wie sich die ICM in G. oxydans $621 \mathrm{H}$ entwickeln. Es wird erörtert, wann und wie häufig die ICM entstehen und ob sie eventuell nur die Folge einer Wachstumsstörung aufgrund des Alters einer Kultur sind oder durch eine Akkumulation cytotoxischer Substanzen hervorgerufen werden. Darüber hinaus werden die Auswirkungen der Substratkonzentration, Wachstumsrate und Zelldichte auf die ICM-Bildung diskutiert.

Da für den Nutzen von ICM für eine gesteigerte Produktbildung letztendlich entscheidend ist, ob ein direkter Zusammenhang zwischen dem Auftreten der ICM und 
einer Steigerung der spezifischen Aktivitäten membranständiger, PQQ-abhängiger Dehydrogenasen besteht, wird unter Berücksichtigung der Wachstumsphase, der Substrate und deren Konzentration, sowie dem Einfluss des Sauerstoffpartialdrucks dieser Zusammenhang analysiert. Abschließend wird die Frage diskutiert, ob die ICM in G. oxydans ein Potential zur Verbesserung der biotechnologischen Anwendung dieses Essigsäurebakteriums darstellen.

Um die biotechnologische Anwendung von G. oxydans zu optimieren wurde ergänzend zur Erweiterung des Grundlagenwissens über die ICM die Idee entwickelt, die Expression von membranständigen Dehydrogenasen während des Wachstums einer Kultur mittels eines fluoreszierenden Fusionsproteins zu verfolgen. Die Entwicklung und Überwachung eines Produktionsstammes während der Fermentation wären mit fluoreszierenden Enzymen möglich (VAN ROESSEL und BRAND, 2002). Eine empirische Untersuchung der optimalen Anzuchtbedingungen mittels der Expression von Fusionsproteinen aus membranständigen Dehydrogenasen und eines fluoreszierenden Proteins, könnte im Hochdurchsatzverfahren erfolgen. Die Diskussion der Expression des auf dem Flavinmononukleotid basierenden fluoreszierenden Proteins (FbFP) in G. oxydans und der Ergebnisse einer ersten translationalen Fusion mit einer membranständigen Dehydrogenase bilden den Abschluss dieser Arbeit.

Im Focus dieser Arbeit stehen die membranständigen Dehydrogenasen und die ICM-Bildung von Gluconobacter oxydans. Die Möglichkeiten zur Optimierung der biotechnologischen Anwendung dieses Bakteriums sind mit mikroskopischen und biochemischen Methoden untersucht worden.

\subsection{Die Lokalisation membrangebundener Enzyme in G. oxydans}

Grundlage für die Lokalisation von Proteinen an Ultradünnschnitten von in Kunstharz eingebetteten Zellen ist die Verfügbarkeit eines entsprechenden IgG-Antikörpers, der gegen das Enzym von Interesse gerichtet sein muss. Ein zweiter Antikörper, an den ein Goldpartikel gekoppelt ist, bindet spezifisch den ersten Antikörper und ist auf einem TEM-Mikrograph als schwarzer Punkt im Bereich des Epitops des Zielproteins sichtbar (Kap. 2.6.3.4). Die Herstellung der Antikörper gegen die große Untereinheit der PolyolDehydrogenase (GOX0854) und gegen die große Untereinheit der Quinol-Oxidase des 
bo3-Typs (GOX1912) ist in Kap. 2.5.5 beschrieben; die hier diskutierten Ergebnisse finden sich in Kap. 3.1.

Zunächst werden die Herstellung der primären Antikörper für die Lokalisation membrangebundener Enzyme mittels Immunogold-Markierung und erste Markierungsexperimente diskutiert.

\subsubsection{Der polyklonale Antikörper gegen die große Untereinheit der membrangebundenen PQQ-abhängigen Polyol-Dehydrogenase GOX0854}

Der Herstellung dieses Antikörpers liegt eine Überexpression und Aufreinigung des Strep-markierten Proteins GOX0854 zugrunde. Die Ernte von Kulturen des Stammes G. oxydans $\Delta$ upp $\Delta$ gox0854/0855 • pBBR1p264-gox0854-Strep/gox0855 erfolgte nach $15 \mathrm{~h}$ Wachstum, weil die Menge an überexprimiertem Protein zu diesem Zeitpunkt nicht mehr anstieg, und ein eventueller Abbau vermieden werden sollte (Abb. 3.1.1.a). Die Aufreinigung eines in Frage kommenden Proteins verlief problemlos (Abb. 3.1.1.b und c) und eine sich anschließende Massenspektrometrie-Analyse ergab, dass sich in der Bande, die aus dem Coomassie gefärbten Polyacrylamidgel ausgeschnitten wurde zu 96,4 \% das gewünschte Protein GOX0854 befand (Tab. 3.1.1.). Die restlichen 3,6 \% entsprachen dem Elongationsfaktor $\mathrm{G}$ aus G. oxydans 621H. Dieser sorgt während der Proteinbiosynthese für die Translokation der mRNA, nachdem eine neue Peptidbindung geknüpft wurde (BERG et al., 2003). Diese leichte Verunreinigung des zur Immunisierung eingesetzten Antigens könnte für etwaige spätere Markierungen im Cytosol verantwortlich sein. Aus Western Blot-Analysen ergab sich, dass das Serum der kleinen Blutung nach $38 \mathrm{~d}$ am besten geeignet ist, welches auch für die in dieser Arbeit gezeigten Western Blots und Immunogold-Markierungen benutzt worden ist.

Das Molekulargewicht (Mw) von GOX0854 beträgt 79,6 kDa, berechnet anhand der Primärstruktur (PRUST et al., 2005). Im Coomassie gefärbten Polyacrylamidgel (Abb. 3.1.1.c) befinden sich die Banden des aufgereinigten Proteins auf der entsprechenden Höhe. Auf dem Bild des Western-Blots (Abb. 3.1.2.b) scheinen die entsprechenden Banden ein wenig höher zu laufen, was mit der geringeren Auflösung des hierfür benutzten Proteinmarkers zu erklären ist. Dass es sich bei den in 
Abb. 3.1.2.b dargestellten kräftigen Banden um das Signal der großen Untereinheit der Polyol-Dehydrogenase GOX0854 handelt, ist durch die Abwesenheit der Bande bei dem rechts neben dem Proteinrohextrakt des Wildtyps aufgetragenen Proteinrohextrakt der Deletionsmutante G. oxydans 621H Aupp Agox0854/0855 bewiesen. Des weiteren zeigt der in Abb. 3.1.2.a dargestellte Western-Blot mit dem Prä-Immunserum beim Wildtyp ebenfalls kein entsprechendes Signal, was darauf hindeutet, dass der betreffende Antikörper erst im Verlauf der Immunisierung des Wirts gebildet wurde. Beide Seren zeigen einen leichten Hintergrund von Banden, an denen man erkennt, dass in den Seren ein sehr geringer Anteil an Antikörpern vorhanden ist, die ebenfalls an Proteine aus G. oxydans $621 \mathrm{H}$ binden können.

In Kap. 3.1.3 sind die Ergebnisse der Immunogold-Markierung an Proben des Wildtyps G. oxydans $621 \mathrm{H}$ und der Deletionsmutante G. oxydans $\Delta$ upp $\Delta$ gox0854/0855 vorgestellt. Die Immunogold-Markierung zeigt im Falle des Wildtyps, dass GOX0854 überwiegend im Bereich der Zellperipherie lokalisiert werden kann (Abb. 3.1.4.). Im Vergleich mit der Deletionsmutante ist der Wildtyp stärker markiert, obwohl die Deletionsmutante ebenfalls eine schwache, primär zellperiphere Markierung aufweist (Abb. 3.1.5.). Die Bedingungen, unter denen die Markierungsexperimente durchgeführt wurden, führten entsprechend zu relativ schwachen Markierungen (vgl. WREDE et al, 2013). Eine schwache Expression oder ein in diesem Fall erschwerter Zugang des primären Antikörpers zu den Epitopen kann natürlich nicht ausgeschlossen werden. Das Blocken wurde mit einer Mischung aus Proteinen, Polypeptiden und Aminosäuren in relativ hoher Konzentration durchgeführt, um unspezifische Bindungen zu unterdrücken. Die Verdünnung des primären Antikörpers war mit 1:1000 ebenfalls recht hoch. Ziel war es, dass einerseits die Deletionsmutante als Negativkontrolle im günstigsten Fall keine Markierungen aufweisen sollte, andererseits die Markierungen aussagekräftig genug sein muss, um die Expression und Lokalisierung der PolyolDehydrogenase unter wechselnden Bedingungen und in verschiedenen Stämmen vergleichen zu können. Dies ist mit dem eingesetzten Serum und der in Kap. 2.6.3.4 beschriebenen Methode möglich.

Die mittels des Antigens GOX0854-Strep hergestellten Antikörper gegen die große Untereinheit der membranständigen Polyol-Dehydrogenase sind geeignet, um die Expression und Lokalisation dieses Enzyms zu untersuchen. 


\subsubsection{Der polyklonale Antikörper gegen die große Untereinheit der membrangebundenen Quinol-Oxidase des bo3-Typs GOX1912}

Der Herstellung dieses Antikörpers liegt die Auswahl und Herstellung von Polypeptiden zugrunde, die zur Immunisierung verwendet werden sollten. Diese Polypeptide, denen eine hohe Antigenität vorausgesagt wurde, sind in der Tab. 3.1.2. aufgeführt.

Der Aufbau von Antikörpern gegen die eingesetzten Antigene durch das Immunsystem der Wirtstiere wurde mittels Western Blot-Analyse verfolgt. Letztendlich wurde eine Aufreinigung des Serums der finalen Blutung nach $87 \mathrm{~d}$ notwendig, die mittels der synthetisierten Antigene durch die Fa. Eurogentec durchgeführt wurde und zu einer hintergrundfreien Antikörperlösung führte. Die Abb. 3.1.3. zeigt die Western BlotAnalyse des im Rahmen dieser Arbeit eingesetzten Serums im Vergleich mit dem PräImmunserum. Das Molekulargewicht von GOX1912 beträgt 74 kDa, ermittelt anhand der Primärstruktur (PRUST et al. 2005). Der Western Blot zeigt, dass die Immunisierung und die sich anschließende Aufreinigung erfolgreich waren. Wenn Proteinrohextrakt des Wildtyps aufgetragen wurde, sind Banden knapp oberhalb der 50 kDa-Markierung zu erkennen. Da diese Banden im Falle des Proteinrohextrakts der Deletionsmutante G. oxydans $\Delta$ upp $\Delta$ gox1911-1914 fehlen und auch im PräImmunserum nicht vorhanden sind, müssen sie das Signal von GOX1912 sein. Es ist ersichtlich, dass sich GOX1912 während der Elektrophorese im Polyacrylamidgel wie ein Protein mit geringerem Mw verhält.

In Kap. 3.1.3.2 sind die Ergebnisse der Immunogold-Markierung mit dem aufgereinigten Serum der finalen Blutung nach $87 \mathrm{~d}$ an Proben des Wildtyps G. oxydans $621 \mathrm{H}$ und der Deletionsmutante G. oxydans $\Delta$ upp $\Delta$ gox 1911-1914 vorgestellt. Aus der Abb. 3.1.6. geht hervor, dass die Markierung von GOX1912 unter den in Kap. 2.6.3.4 beschriebenen Bedingungen relativ schwach ist, trotz der vergleichsweise geringen Konzentration an Blockierlösung aus Proteinen, Polypeptiden und Aminosäuren (vgl. WREDE et al, 2013). Eine schwache Expression, oder ein in diesem Fall schwieriger Zugang zu den Epitopen kann natürlich nicht ausgeschlossen werden. Um unspezifische Bindungen zu unterdrücken war die Verdünnung des primären Antikörpers mit 1:1000 recht hoch. Dies war aber nötig, damit Zellen der Deletionsmutante keine Markierungen aufweisen (Abb. 3.1.7.), während die Markierungen anderer Stämme aussagekräftig genug sind, um die Expression und Lokalisierung der Quinol-Oxidase unter wechselnden Bedingungen und in verschiedenen Stämmen vergleichen zu können. Dies 
ist mit dem eingesetzten Serum und der in Kap. 2.6.3.4 beschriebenen Methode möglich. Aus der Abb. 3.1.6. ist ebenfalls ersichtlich, dass GOX1912 ausschließlich an der Zellperipherie detektiert wird, sowie nach $8 \mathrm{~h}$ Wachstum (a) dort etwas häufiger lokalisiert ist als nach $24 \mathrm{~h}$ Wachstum (b).

Die mittels synthetisierter Polypeptide als Antigene hergestellten Antikörper gegen die große Untereinheit der Quinol-Oxidase des bo3-Typs sind dazu geeignet, Aussagen über die Expression und Lokalisation dieses Enzyms zu treffen.

\subsubsection{Die Lokalisierung der großen Untereinheit der membran- gebundenen PQQ-abhängigen Polyol-Dehydrogenase GOX0854 in Stämmen, die GOX0854/0855 ausschließlich ektopisch exprimieren}

Die von Kooperationspartnern dieser Arbeit zur Verfügung gestellten Stamm-Derivate von G. oxydans $621 \mathrm{H}$ mit deletierter und anschließend komplementierter PolyolDehydrogenase GOX0854/0855 sind mittels Immunogold-Markierung analysiert worden. Die zur Komplementation benutzten Plasmide unterscheiden sich durch die Promotorregionen, die vor das Gen für GOX0854/0855 kloniert wurden. Zum einen handelt es sich um den Stamm G. oxydans $\Delta$ upp $\Delta$ gox0854/0855 • pBBR1p264gox0854-Strep /gox0855, der im Folgenden als Gox0854-Strep bezeichnet wird. Dieser Stamm ist auch für die Herstellung des Antikörpers gegen GOX0854 genutzt worden. Zum anderen sind es die Stämme G. oxydans $\Delta$ upp $49 x 2 \cdot$ pBBR1pQIDHgox0854/gox0855, kurz Gox-pQIDH-GOX0854/0855 und G. oxydans $\Delta$ upp $49 x 2$. pBBR1pADH-gox0854/gox0855, kurz Gox-pADH-GOX0854/0855. Die Anzucht erfolgt unter Standardbedingungen. Die Abbildungen 3.1.8. bis 3.1.11. zeigen Zellen der komplementierten Deletionsmutanten, die in $8 \mathrm{~h}$ gewachsen sind. Diesen Stämmen ist gemein, dass sie im Gegensatz zur unkomplementierten Deletionsmutante auf Mannitol wachsen können (PETERS et al., 2013). Darüber hinaus zeigen die Immunogold-Markierungen eine Expression der Polyol-Dehydrogenase in allen hier vorgestellten Stämmen.

Komplementationsmutanten, in denen die Polyol-Dehydrogenase ektopisch unter der Kontrolle unterschiedlicher Promotoren exprimiert wird, wurden mittels 
Immunogold-Markierung mit dem Antikörper gegen die große Untereinheit der Polyol-Dehydrogenase untersucht.

\subsubsection{Gox0854-Strep mit Immunogold-markierter GOX0854}

Die Expression der membranständigen Polyol-Dehydrogenase steht in diesem Stamm unter der Kontrolle des Promotors p264, der in G. oxydans $621 \mathrm{H}$ die Expression des ribosomalen Proteins L35 (GOX0264) kontrolliert (KALLNIK et al., 2010). Verglichen mit dem Wildtyp (Abb. 3.1.4.) zeigen die in Abb. 3.1 .8 dargestellten Zellen von Gox0854-Strep eine in Qualität und Quantität schwächere Markierung der großen Untereinheit der Polyol-Dehydrogenase GOX0854. Dargestellt sind zwei Beispiele von Zellen, die markierte ICM enthalten. Ein gehäuftes Auftreten von ICM in diesem Stamm war aber nicht $\mathrm{zu}$ beobachten, bzw. sind dafür statistische Erhebungen notwendig, wie sie in Kap. 2.6.3.3 beschrieben worden sind. Es ist jedoch zu erwähnen, dass im Rahmen dieser Arbeit markierte ICM selten zu sehen waren. Neben den hier diskutierten Elektronenmikrographien konnten noch weitere eindeutig markierte ICM im Wildtyp gezeigt werden (Abb. 3.3.5. und Abb. 3.1.4.). Dies bedeutet, dass die Hälfte der eindeutig markierten ICM im Stamm Gox0854-Strep zu sehen waren, so dass eine weitere Untersuchung mittels statistischer Erfassung sinnvoll wäre.

Unter der Kontrolle des Promotors p264 ist die Markierung der PolyolDehydrogenase im Vergleich mit dem Wildtyp schwächer. Allerdings wäre es sinnvoll, das Vorkommen an ICM in diesem Stamm statistisch zu untersuchen.

\subsubsection{Gox-pQIDH-GOX0854/0855, auf Mannitol oder Sorbitol angezogen mit Immunogold-markierter GOX0854}

Der Stamm Gox-pQIDH-GOX0854/0855 exprimiert die Polyol-Dehydrogenase unter dem Einfluss des Promotors der Inositol-Dehydrogenase GOX1857 (HÖLSCHER et al., 2007). Bisher unveröffentlichte Daten der AG Ehrenreich, TU München, deuten auf die Induzierbarkeit dieses Promotors durch die zur Anzucht benutzten Substrate hin. Je nachdem, ob der Stamm mit Mannitol oder Sorbitol als Substrat angezogen wurde, ist eine unterschiedliche Aktivität des Promotors erwartet worden. Dies könnte in diesem 
Fall zu einer variierenden Menge an exprimierter Polyol-Dehydrogenase führen. Mit Mannitol angezogene Immunogold-markierte Zellen des Stammes Gox-pQIDHGOX0854/0855 sind in Abb. 3.1.9. dargestellt. Die Intensität der Markierung erscheint etwas schwächer als die des Wildtyps (Abb. 3.1.4.). Auffällig ist eine gegenüber anderen Markierungsexperimenten stärkere Markierung des Cytoplasmas. Dies könnte auf eine besonders starke Proteinsyntheseaktivität und einer damit einhergehenden häufigeren Markierung des Elongationsfaktors G hindeuten. Ein gestörter Einbau in die Cytoplasmamembran, bzw. ein erhöhter Abbau der Polyol-Dehydrogenase im Cytoplasma, hervorgerufen durch die Überexpression der Polyol-Dehydrogenase ist ebenfalls möglich. Allerdings wurde für Mannitol als Substrat eine schwächere Promotoraktivität als mit Sorbitol erwartet. Die Abb. 3.1.10. zeigt Immunogoldmarkierte Zellen des Stammes Gox-pQIDH-GOX0854/0855, die mit Sorbitol angezogen worden sind. Hier ist die Markierung eher in der Peripherie der Zellen zu finden, wenngleich auch das Cytoplasma markiert ist. Für diesen Stamm ist kein signifikanter Unterschied in der Intensität der Markierungen unter den beiden getesteten Bedingungen festzustellen, insgesamt sind sie etwas schwächer als im Wildtyp (Abb. 3.1.4.). Es ist denkbar, dass G. oxydans unter diesen Bedingungen PolyolDehydrogenasen im Cytosol abbaut, oder zumindest nicht in die Cytoplasmamembran einbaut.

Im Vergleich mit dem Wildtyp führt der mutmaßlich induzierbare Promotor pQIDH zu einer insgesamt schwächeren Markierung der Polyol-Dehydrogenase. Auffällig ist die vergleichsweise starke Markierung des Cytosols. Ein signifikanter Unterschied in der Quantität der Markierung zwischen der Anzucht des Stammes auf Mannitol und Sorbitol ist nicht festzustellen.

\subsubsection{Gox-pADH-GOX0854/0855 mit Immunogold-markierter GOX0854}

Im Fall des Stamms Gox-pADH-GOX0854/0855 steht die Expression der membranständigen Polyol-Dehydrogenase unter der Kontrolle des Promotors für die Alkohol-Dehydrogenase GOX1067/1068 (Abb. 3.1.11.). Die Markierung von GOX0854 ist hier schwächer als beim Wildtyp und ist nicht auf den peripheren Bereich der Zellen beschränkt. Es scheint die schwächste detektierbare Expression von GOX0854 zu sein, die im Rahmen dieser Arbeit untersucht wurde. 
Die Expression der Polyol-Dehydrogenase unter der Kontrolle des pADHPromotors ist sehr schwach.

\subsubsection{Die Promotoranalyse mittels der Immunogold-Markierung von GOX0854}

Fasst man die in diesem Kapitel beschriebenen Beobachtungen zusammen, so kann man zu dem Schluss gelangen, dass der Antikörper gegen die Strep-markierte große Untereinheit der membranständigen Polyol-Dehydrogenase GOX0845 zur Untersuchung der Expression und Lokalisation geeignet ist. Unter den beschriebenen Versuchsbedingungen ist sowohl eine Unterscheidung zwischen Wildtyp und Deletionsmutante im Western Blot, als auch mit der Immunogold-Markierung möglich. Die ersten Anwendungen im Falle der Promotoranalyse ergaben, dass der Promotor p264, der in G. oxydans $621 \mathrm{H}$ die Expression des ribosomalen Proteins L35 (GOX0264) kontrolliert (KALLNIK et al., 2010), im Vergleich zum Wildtyp zu einer etwas schwächeren, aber überwiegend peripheren Markierung führt. Die Expression der Strep-markierten Polyol-Dehydrogenase unter der Kontrolle des p264-Promotors könnte allerdings zu einer gesteigerten Menge an ICM führen, so dass man diesen Stamm mittels statistischer Auswertung der ICM-Menge und Aktivitätstests untersuchen sollte. In Kap. 4.6 werden die Ergebnisse der Expression eines fluoreszierenden Proteins unter Kontrolle dieses und weiterer Promotoren diskutiert, darüber hinaus ist mit diesem Promotor die membrangebundene, PQQ-abhängige Glucose-Dehydrogenase (GAOX0265) bereits erfolgreich überexprimiert worden (MEYER et al., 2013).

Der Promotor der Inositol-Dehydrogenase GOX1857 führt zu einer im Vergleich zum Wildtyp schwächeren Markierung der großen Untereinheit der Polyol-Dehydrogenase sowie zu einer verstärkten Markierung des Cytoplasmas. Dies könnte darauf hindeuten, dass der Promotor, bzw. das benutzte Plasmid oder das in der vorliegenden Form entstandene Konstrukt für die Überexpression ungeeignet ist. Des Weiteren ist ein signifikanter Einfluss auf die Intensität der Markierung und damit auf die Expression durch die zur Anzucht der Kulturen benutzten Substrate Mannitol oder Sorbitol nicht erkennbar.

Die Expression der membranständigen Polyol-Dehydrogenase unter der Kontrolle des Promotors für die Alkohol-Dehydrogenase GOX1067/1068 führt zu einer sehr schwachen, teilweise im Cytoplasma lokalisierten Markierung. Da ein Zusammenhang zwischen Markierungsstärke, der Expression und der spezifischen Aktivität gegenüber 
den Polyol-Dehydrogenase-Substraten Mannitol und Glycerol nicht auszuschließen ist (Kap. 4.3) kann man davon ausgehen, dass unter den getesteten Bedingungen der pADH-Promotor sich am wenigsten für die Überexpression membranständiger Dehydrogenasen in G. oxydans $621 \mathrm{H}$ eignet.

Die ektopische Expression unter der Kontrolle der hier untersuchten Promotoren führt zu schwächeren Immunogold-Markierungen im Vergleich zum Wildtyp. Da der Promotor pADH die schwächste Markierung hinterlässt und der Promotor pQIDH eine verstärkte Markierung des Cytosols verursacht, scheint der Promotor p264 nach den hier gemachten Beobachtungen am ehesten zur Expression geeignet zu sein. Eine forcierte ICM-Bildung in diesem Stamm ist nicht auszuschließen.

\subsection{Die Untersuchung der Entwicklung und des Vorkommens intracytoplasmatischer Membranen in G. oxydans $621 \mathrm{H}$}

Die optimalen Bedingungen für die vielen möglichen Biokonversionen durch G. oxydans ausschließlich empirisch zu ermitteln könnte dazu führen, dass das volle Potential dieses Organismus nicht ausgeschöpft wird. Eine Erweiterung des Grundlagenwissens über die intracytoplasmatischen Membranen (ICM) in G. oxydans,

z. B. ihre Entstehung, Entwicklung und Rolle als Standort für membranständige Dehydrogenasen könnte zukünftige Fermentationsprozesse beschleunigen, effektiver und damit wirtschaftlicher gestalten. In den Arbeiten von CLAUS et al. (1975) und HEEFNER und CLAUS (1982) wird ein erhöhter Substratumsatz durch Zellen von G. oxydans beschrieben, die sich in der stat. Wachstumsphase befinden. Dies wird mit einem zeitgleichen Auftreten von ICM in Verbindung gebracht und durch zusätzliche membranständige Dehydrogenasen erklärt. Laut diesen Studien sind die ICM-Vesikel an den Zellpolen lokalisiert und stehen mit der Cytoplasmamembran (CM) in Kontakt. Eine Akkumulation von Ribosomen in diesem Bereich sollte auf eine verstärkte ProteinSyntheseaktivität hindeuten. Hervorzuheben ist, dass die beobachteten Strukturen sich von den artifiziellen Mesosomen unterscheiden. Die verwendete Methode der Einbettung bringt in anderen Gram-negativen oder Gram-positiven Bakterien keine Mesosomen hervor (SILVA et al., 1976). 
Dieses Kapitel ist der Frage gewidmet, wie sich die ICM in G. oxydans 621H entwickeln und ob sie mit dem Periplasma in Kontakt stehen. Es werden die Fragen beantwortet, wann und wie häufig die ICM entstehen, ob sie eventuell nur die Folge einer Wachstumsstörung sind, die aufgrund des Alters einer Kultur oder durch Dihydroxyaceton, dem Produkt der Oxidation von Glycerol, hervorgerufen werden. In diesem Zusammenhang werden Unterschiede in der ICM-Entwicklung beim Wachstum auf Glycerol und Mannitol herausgearbeitet. Darüber hinaus werden die Auswirkungen der Substratkonzentration, Wachstumsrate und Zelldichte auf die ICM-Bildung diskutiert.

Die Entstehung und Entwicklung von ICM sowie ihre mögliche Eigenschaft, Standort für membranständige Dehydrogenasen zu sein, werden im Folgenden diskutiert.

\subsubsection{Die Differenzierung der Cytoplasmamembran}

Für die Entstehung von ICM sind zwei Möglichkeiten in Betracht zu ziehen. Möglich wären ein Hervorgehen aus der Cytoplasmamembran (CM) durch Invagination oder eine davon unabhängige Synthese innerhalb des Cytoplasmas (OELZE und DREWS, 1971). In Kapitel 3.2.1 sind TEM-Mikrographien einer $24 \mathrm{~h}$ alten Kultur von G. oxydans $621 \mathrm{H}$ in einer Reihenfolge dargestellt, die eine mögliche Abfolge von Entwicklungsschritten darstellt. Die Abb. 3.2.1.a zeigt, dass die Bildung von ICM an den Zellpolen initiiert wird. Die ICM sind zunächst nicht eindeutig von der CM zu unterscheiden, was auf eine Entwicklung der ICM aus der CM hindeutet. Die ICM in der Abb. 3.2.1.b scheint sich als Folge einer möglichen Invagination nach innen zu falten und beginnt einen kleinen Bereich des Cytoplasmas zu umschließen. In der Abb. 3.2.2.a ist dieser Prozess bereits fortgeschritten; deutlich sind hier mehrere von ICM umschlossene Bereiche des Cytoplasmas zu erkennen, die aber nach wie vor Ribosomen enthalten. Schnüren sich Membranvesikel von der CM durch Invagination $\mathrm{ab}$, müssten diese wie der periplasmatische Raum, frei von Ribosomen sein. Neben dem direkten Hervorgehen der ICM aus der CM wird auch eine von der CM unabhängige Entwicklung der ICM diskutiert, die manchmal auch an der CM stattfinden kann (OELZE und DREWS, 1971; SEGEN und GIBSON, 1971). Dies könnte ebenfalls den 
offensichtlichen Ursprungsort der ICM an der CM und die Beobachtung erklären, dass ICM-Vesikel in Kontakt mit der CM stehen (CLAUS et al., 1975). Die von HEEFNER und CLAUS (1978) beschriebene Änderung der Fettsäuren-Zusammensetzung der Membranen, in dem sich der Anteil der veresterten Fettsäuren von der unverzweigten Hexadecansäure zur Anteiso-Palmitinsäure verschiebt, könnte ein Hinweis auf eine de novo-Synthese von ICM-Vesikeln darstellen. Im Gegensatz zur CM könnten für ICM fluidere Membranen gebraucht werden, um die ICM-Vesikel in der Zelle flexibler zu halten. Die weitere Entwicklung könnte ein Abbau der Ribosomen und die Bildung eines Lumen sein, was zu ICM-Vesikeln führt, wie sie in der Abb. 3.2.2.b mit den schwarzen Pfeilen markiert, dargestellt sind. In derselben Zelle ist auch ein mit ICM umschlossener Bereich zu sehen, der offensichtlich (noch) Ribosomen enthält, die aber im Vergleich zum umgebenen Cytoplasma ein wenig heller und weniger konturiert zu sein scheint. Da ein gesteigerter Abbau der sonst relativ stabilen Ribosomen für den Zeitpunkt zwischen exp. und stat. Wachstumsphase in E. coli beschrieben worden ist (PIIR et al., 2011), könnte der Übergang von G. oxydans in die stat. Wachstumsphase und die fortschreitende Entwicklung der ICM-Vesikel ebenfalls mit einem intensivierten Abbau von Ribosomen einhergehen. Das Ergebnis dieser Entwicklung sind von ICM umschlossene Bereiche oder Vesikel, die keine Ribosomen enthalten und in einem TEM-Mikrograph bis zu $20 \%$ der dargestellten Fläche einer Zelle ausmachen können (Abb. 3.2.3.). Ob diese Bereiche oder Vesikel in Kontakt mit dem Periplasma stehen, lässt sich anhand dieser Bilder nicht feststellen. Es ist aber an dieser Stelle auf die Abb. 3.1.8. einzugehen, die Immunogold-markierte Polyol-Dehydrogenasen einer G. oxydans-Zelle darstellt. Markiert sind einerseits ICM, die mit der CM in Kontakt stehen und die einen Bereich mit Ribosomen umschließen. Darüber hinaus ist auch ein ICM-Vesikel markiert, der keine Ribosomen enthält. Die Abb .3.3.5.a zeigt ein ICM-Vesikel, deren Membran zum einen mit dem Antikörper gegen die Polyol-Dehydrogenase markiert ist, und zum anderen einen Bereich mit und einen Bereich ohne Ribosomen zeigt. In der Abb. 4.2.1 ist ein anschauliches

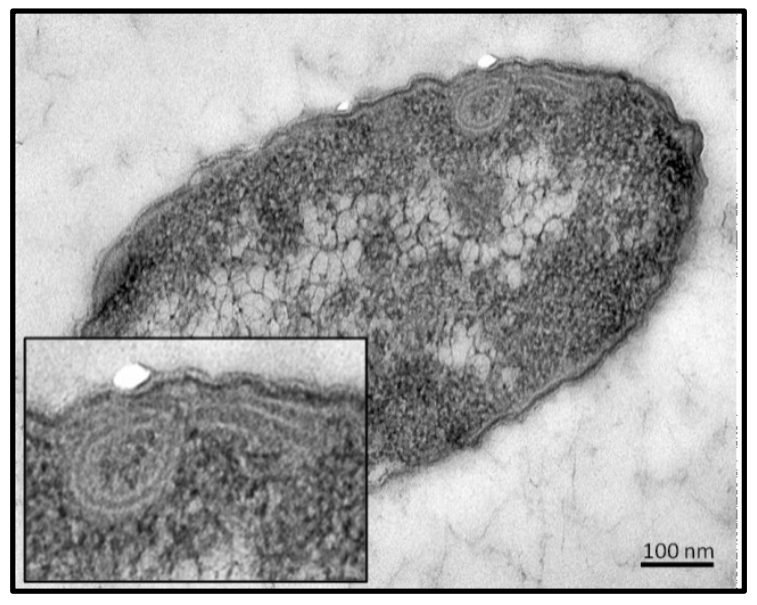

Abb. 4.2.1.: G. oxydans 621H mit ICM

TEM von $G$. oxydans $621 \mathrm{H}$ angezogen mit $1 \mathrm{M}$ Mannitol über 8 h. Vergrößerter Ausschnitt zeigt ein ICM-Vesikel an der Cytoplasmamembran. 
Beispiel für die hier diskutierten Beobachtungen dargestellt. Es lässt die Hypothese zu, dass sich die ICM-Vesikel an den CM, aber innerhalb des Cytoplasmas entwickeln und zunächst noch Ribosomen enthalten, die anschließend abgebaut werden. Die ICM sollten zumindest zeitweise den Kontakt zum Periplasma behalten, oder den Kontakt mittels der flexibleren ICM-Membranen aufnehmen, da den sich in der ICM befindenden Dehydrogenasen sonst der Zugang zu Substraten verschlossen bleibt. Mit einem Antikörper gegen im Periplasma lokalisierte Enzyme könnte dieser Sachverhalt mittels Immunogold-Markierung aufgeklärt werden.

Für ein hervorgehen der ICM aus der CM in G. oxydans spricht, dass sich der Ort der ICM-Entstehung in räumlicher Nähe zur CM befindet. Es fehlen aber elektronenmikroskopische Aufnahmen, die eine Invagination der CM eindeutig belegen. Dass in den ICM-Vesikeln Ribosomen vorhanden sein können, deutet auf eine von der CM unabhängige Entstehung im Cytosol hin.

\subsubsection{Das Vorkommen der ICM - Abhängig von Wachstumsphasen, Substrat und deren Konzentration}

Zunächst konnte bestätigt werden, dass ICM in $G$. oxydans vorkommen. Dies beschränkt sich nicht nur auf die stat. Wachstumsphase, wenngleich der Anteil an Zellen, die ICM enthalten in der frühen stat. Wachstumsphase am höchsten $\mathrm{zu}$ sein scheint (Kap. 3.2.2). Im Rahmen dieser Arbeit sind zahlreiche Elektronenmikrographien von $G$. oxydans mit Strukturen innerhalb der Zellen entstanden; die Abb. 3.1.4., 3.1.8. und 3.3.5. zeigen zudem ICM mit Immunogold-markierten PolyolDehydrogenasen in der GOX0854-Strepexprimierenden Mutante, bzw. im Wildtyp G. oxydans. Im Allgemeinen

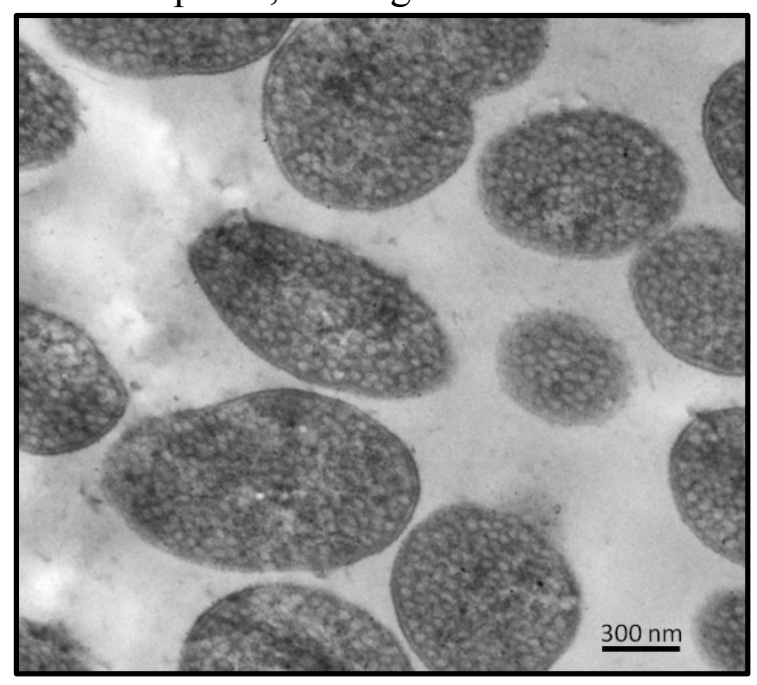

Abb. 4.2.2.: Rhodobacter sphaeroides

TEM von Rhodobacter sphaeroides. Anaerob, im Licht und mit Succinat angezogen. treten ICM in G. oxydans jedoch nicht sehr häufig auf. Als vergleichendes Beispiel ist 
in Abb. 4.2.2. eine Kultur von Rhodobacter spaeroides dargestellt, die im Licht, unter Sauerstoffausschluss und mit Succinat als Elektronendonor für die anoxigene Photosynthese angezogen wurden. Das Cytoplasma jeder Zelle ist mit zahlreichen Membranvesikeln angefüllt. Ein weiteres Beispiel stellt Azotobacter vinelandii dar. Bei hoher Zelldichte, bzw. geringer Sauerstoffkonzentration befinden sich in so gut wie jeder Zelle ICM (PATE et al., 1973). Die statistische Auswertung des Vorkommens an ICM bei Anzucht auf verschiedenen Mannitol- und Glycerol-Konzentrationen ergab eine Schwankung von 1,35 \% bis 9,58 \% des Anteils an Zellen mit ICM innerhalb einer Kultur (Kap. 3.2.2). Eine Beschränkung der Lokalisierung der ICM auf die Zellpole war nicht zu beobachten, der Eindruck einer Tendenz in diese Richtung kann nicht mit belastbaren Zahlen bestätigt werden. Des Weiteren wurde von CLAUS et al. (1975) ein gehäuftes Auftreten von Ribosomen an den Zellpolen festgestellt und mit dem Aufbau an ICM an dieser Stelle in Verbindung gebracht. Es ist bekannt, dass in stäbchenförmigen Zellen Ribosomen an Zellpolen aktiver sind und häufiger vorkommen (MASCARENHAS et al., 2001). Man gewinnt aber auch den Eindruck, dass Ribosomen an der Zellperipherie einfach auch mehr Platz haben, da sich im Zentrum der Zelle das im TEM-Elektronenmikrograph als heller, fein strukturierter Bereich erscheinende Nucleoid befindet (ROBINOW und KELLENBERGER, 1994).

Die in Kap. 3.2.2 untersuchten Kulturen, angezogen mit unterschiedlichen Konzentrationen von Glycerol oder Mannitol, befinden sich alle nach $8 \mathrm{~h}$ Wachstum in der exp. Wachstumsphase (Abb. 3.2.4. und 3.2.5.). Bei allen getesteten Substraten und Konzentrationen ist nach $24 \mathrm{~h}$ die stat. Wachstumsphase erreicht, ausgenommen ist das Wachstum mit 1,0 M Glycerol, hier wird der Eintritt in die stat. Wachstumsphase erst nach ca. $36 \mathrm{~h}$ erreicht. Im Allgemeinen enthalten die Zellen nach $8 \mathrm{~h}$ Wachstum weniger ICM als nach $24 \mathrm{~h}$ Wachstum (Abb. 3.2.6.). Nach $48 \mathrm{~h}$ bleibt der Anteil der Zellen mit ICM relativ konstant, geht eher noch etwas zurück. Ein gehäuftes Auftreten an ICM oder ICM-ähnlichen Strukturen in G. oxydans $621 \mathrm{H}$ aufgrund eines gestörten Wachstums als Folge des Alters einer Kultur erscheint demnach unwahrscheinlich. Die Abb. 3.2.7. stellt den Anteil an Zellen, die ICM enthalten nach der Substratkonzentration geordnet dar. Daraus ist ersichtlich, dass im Allgemeinen ICM umso häufiger auftreten, je höher die Substratkonzentration ist, was in dem sich anschließenden Kapitel genauer diskutiert wird. Das Wachstum mit Mannitol als Substrat führt i. d. R. zu einem häufigeren Vorkommen an ICM in den Zellen von G. oxydans als Glycerol. Ein gestörtes Wachstum als Folge einer Akkumulation von 
wachstumshemmenden Dihydroxyaceton ist somit kein Grund für ein gehäuftes Auftreten an ICM oder ICM-ähnlichen Strukturen in G. oxydans 621H.

ICM können in G. oxydans überall in der Zelle auftreten, sind aber relativ selten. Am häufigsten sind sie nach $24 \mathrm{~h}$ Wachstum in der stat. Wachstumsphase zu beobachten. Beim Wachstum mit Mannitol als Substrat ist der Anteil an Zellen, die ICM enthalten höher als mit Glycerol. Somit sind ICM keine Wachstumsstörung als Folge des Alters einer Kultur oder der Anhäufung von Dihydroxyaceton.

\subsubsection{Der Einfluss der Wachstumsparameter auf die ICM-Bildung}

Für die Entwicklung der ICM des zu den Pseudomonaden gehörenden Bakteriums Azotobacter vinelandii wird vermutet, dass der zunehmende Mangel an Sauerstoff in Folge der Zunahme an Zelldichte einer wachsenden Kultur die Menge an ICM steigert (PATE et al., 1971). Auf den Einfluss von Sauerstoff auf die Enzymaktivität wird in Kap. 4.4 genauer eingegangen. An dieser Stelle wird der nach 48 h Wachstum erreichte Anteil an Zellen, die ICM enthalten mit den Wachstumsparametern wie der max. Wachstumsrate und der $\mathrm{OD}_{600}$ nach $48 \mathrm{~h}$ diskutiert.

Beim Wachstum auf Mannitol lässt sich ein recht einfacher Zusammenhang zwischen den Wachstumsparametern und des nach $48 \mathrm{~h}$ erreichten Anteils an Zellen mit ICM erkennen. Die Wachstumskurven sind in Abb. 3.2.5. dargestellt und der Anteil an Zellen, die ICM enthalten sind nach Substratkonzentrationen geordnet der Abb. 3.2.7. zu entnehmen. Die hier diskutierten Werte sind in der Tab. 4.2.1. zusammengefasst.

Tabelle 4.2.1.: G. oxydans $621 \mathrm{H}$ mit unterschiedlichen Mannitol-Konzentrationen

\begin{tabular}{cccc}
\hline $\begin{array}{c}\text { Mannitol } \\
\text { [Mol/Liter] }\end{array}$ & $\begin{array}{c}\text { Max. Wachstumsrate } \\
{[\mathbf{1} / \mathbf{h}]}\end{array}$ & $\begin{array}{c}\mathbf{O D}_{\mathbf{6 0 0}} \text { nach } \\
\mathbf{4 8} \mathbf{~ h} \text { Wachstum }\end{array}$ & $\begin{array}{c}\text { Anteil an Zellen } \\
\text { mit ICM [\%] }\end{array}$ \\
\hline $\mathbf{0 , 1}$ & 0,39 & 2,37 & 4,23 \\
$\mathbf{0 , 5}$ & 0,43 & 4,08 & 4,74 \\
$\mathbf{1 , 0}$ & 0,59 & 4,57 & 5,68 \\
\hline
\end{tabular}


Mit ansteigender Mannitol-Konzentration wird in der exp. Wachstumsphase eine höhere max. Wachstumsrate erreicht. Dies führt nach $48 \mathrm{~h} \mathrm{zu}$ einer höheren $\mathrm{OD}_{600}$ und $\mathrm{zu}$ einem größeren Anteil an Zellen, die ICM enthalten. Dieser einfache Zusammenhang ist beim Wachstum mit unterschiedlichen Glycerol-Konzentrationen nicht herzustellen. Die Wachstumskurven sind in Abb. 3.2.4. dargestellt und der Anteil an Zellen, die ICM enthalten der Abb. 3.2.7. zu entnehmen. Die hier diskutierten Werte sind in der Tab. 4.2.2. zusammengefasst.

Tabelle 4.2.2.: G. oxydans 621H mit unterschiedlichen Glycerol-Konzentrationen

\begin{tabular}{cccc}
\hline $\begin{array}{c}\text { Glycerol } \\
{[\text { Mol/Liter }]}\end{array}$ & $\begin{array}{c}\text { Max. Wachstumsrate } \\
{[\mathbf{1} / \mathbf{h}]}\end{array}$ & $\begin{array}{c}\text { OD }_{\mathbf{6 0 0}} \text { nach } \\
\mathbf{4 8} \mathbf{h} \text { Wachstum }\end{array}$ & $\begin{array}{c}\text { Anteil an Zellen } \\
\text { mit ICM [\%] }\end{array}$ \\
\hline $\mathbf{0 , 1}$ & 0,34 & 1,65 & 3,44 \\
$\mathbf{0 , 5}$ & 0,25 & 3,81 & 3,13 \\
$\mathbf{1 , 0}$ & 0,23 & 2,51 & 3,2 \\
\hline
\end{tabular}

Hier sinkt im Gegensatz zum Wachstum mit Mannitol die max. Wachstumsrate bei steigender Substratkonzentration und eine hohe Konzentration führt nicht zwingend zu höheren $\mathrm{OD}_{600}$ nach 48 h. Der Anteil an Zellen, die ICM enthalten zeigt hier keinen direkten Zusammenhang zu einem der aufgelisteten Wachstumsparameter.

Deshalb kann man aufgrund der hier vorliegenden Daten zu der Erkenntnis gelangen, dass die Zelldichte an sich keinen Einfluss auf den Anteil an Zellen hat, die ICM enthalten. Während sich die erreichten $\mathrm{OD}_{600}$ bei einer Verzehnfachung der Substratkonzentration von Mannitol um den Faktor 1,9 und von Glycerol um 2,3 ungefähr verdoppeln, steigt der Anteil an ICM bei Mannitol um den Faktor 1,3 und bei Glycerol sinkt er sogar leicht.

Es ist davon auszugehen, dass die max. Wachstumsraten einer Kultur von Mikroorganismen umso höher sind, je mehr die Wachstumsbedingungen den jeweiligen Bedürfnissen der Mikroorganismen entsprechen (MONOD, 1949). Demnach ist die hohe Mannitol-Konzentration von 1,0 M für G. oxydans wachstumsfördernd; je höher die Substratkonzentration, desto größer ist die max. Wachstumsrate. Mannitol kann energiebringend zu Fructose oxidiert werden, die Fructose von der Zelle aufgenommen und dem Metabolismus zugeführt werden (Kap. 1.4). Je mehr Mannitol vorhanden ist, desto größer ist die Produktion an Biomasse. 
Im Falle des Glycerols scheint G. oxydans umso besser zu wachsen, je weniger Substrat zur Verfügung steht. Die sinkende max. Wachstumsrate steht im Einklang mit der Erkenntnis, dass das durch die Oxidation von Glycerol entstehende Dihydroxyaceton das Wachstum von G. oxydans stört (OHREM und MERCK, 1996; OHREM und VOSS, 1996). Die höchste optische Dichte wird allerdings auch beim Wachstum mit Glycerol bei einer Konzentration von 1,0 M erreicht, da auch hier die größere Substratmenge mehr Biomasseproduktion ermöglicht.

Die größten max. Wachstumsraten führen mit beiden Substraten letztendlich zu dem höchsten Anteil an Zellen, die ICM enthalten. Bei 1,0 M Mannitol wird eine max. Wachstumsrate von $0,59 / \mathrm{h}$ erreicht und der Anteil an Zellen, die ICM enthalten beträgt 5,68 \%. Bei 0,1 M Glycerol ist die max. Wachstumsrate 0,34/h, der Anteil an Zellen mit ICM beträgt 3,44\%. ICM sind demnach in vitalen Kulturen häufiger in den Zellen vorhanden, als in Kulturen in denen das Wachstum nicht optimal ist. Die Gründe für ein gehäuftes Auftreten an ICM oder ICM-ähnlichen Strukturen in G. oxydans 621H sind demnach weder ein verzögertes, langsames Wachstum, noch ein gestörtes Wachstum in Folge des Alters einer Kultur bzw. einer Anhäufung wachstumshemmender Substanzen.

Die Zelldichte hat keinen Einfluss auf den Anteil an Zellen, die ICM enthalten. Die Substratkonzentration hat über die Wachstumsrate einen indirekten Einfluss auf die ICM-Menge; viel Mannitol, sowie wenig Glycerol fördern das Wachstum und erhöhen damit den Anteil an Zellen, die ICM enthalten.

\subsection{Intracytoplasmatische Membranen, spezifische Enzymaktivitäten membranständiger Dehydrogenasen und die Expression der Polyol-Dehydrogenase - eine nähere Betrachtung}

Nachdem nun die Entwicklung von ICM und mögliche Gründe für ihr Vorkommen in G. oxydans diskutiert wurden, widmet sich dieses Kapitel der Frage, ob ein direkter Zusammenhang zwischen dem Auftreten der ICM und den spezifischen Aktivitäten membranständiger, PQQ-abhängiger Dehydrogenasen besteht. Dies wird unter Berücksichtigung der Wachstumsphase oder der Substratkonzentration analysiert. Immunogold-Markierungen der Polyol-Dehydrogenase werden ebenfalls in die Analyse 
mit einbezogen, deren Substrate u. a. Mannitol und Glycerol sind, für die auch spezifischen Enzymaktivitäten ermittelt wurden.

Im Folgenden wird der Einfluss von ICM auf die spezifische Enzymaktivität von membranständigen, PQQ-abhängigen Dehydrogenasen diskutiert.

\subsubsection{Besteht ein direkter Zusammenhang zwischen ICM-Menge und spezifischer Aktivität membranständiger Dehydrogenasen?}

Eine bemerkenswerte Ausnahme der Beobachtung, dass nach $24 \mathrm{~h}$ mehr ICM in den Zellen vorhanden sind als nach $8 \mathrm{~h}$, bilden die 0,5 M Mannitol-Proben. Hier sinkt der Anteil an Zellen, die ICM enthalten von der exp. zur stat. Wachstumsphase von 5,45 \% auf 4,02 \%. Im gleichen Zeitraum steigt beim Wachstum mit 0,5 M Glycerol, dem allgemeinen Trend folgend, der Anteil an Zellen mit ICM von 1,35 \% auf 4,57\% (Abb. 3.2.7.). Es war somit interessant, diesen Umstand eingehender zu untersuchen, zumal die entsprechenden Standardabweichungen in diesem Fall sehr gering sind. Möglicherweise kann anhand der 0,5 M-Proben eine Korrelation zwischen den jeweiligen ICM-Mengen und spezifischen Aktivitäten aufgezeigt oder widerlegt werden. Das Ergebnis der Enzymaktivitätstests membranständiger Dehydrogenasen beim Wachstum auf 0,5 M Mannitol und 0,5 M Glycerol nach $8 \mathrm{~h}$ und $24 \mathrm{~h}$ Wachstum ist in den Abb. 3.2.8. und 3.2.9. dargestellt.

Darüber hinaus werden die Immunogold-Markierungen der Polyol-Dehydrogenase in die Analyse mit einbezogen. Mannitol und Glycerol sind Substrate der PolyolDehydrogenase, die in den hier besprochenen Enzymaktivitätstests neben Ethanol und Glucose als Testsubstrate eingesetzt wurden. Die entsprechenden TEMElektronenmikrographien sind in den Abb. 3.2.10. und 3.2.11. dargestellt.

Beim Wachstum mit 0,5 M Glycerol steigt die spezifische Aktivität mit Ethanol und Glycerol als Substrat für die membranständigen, PQQ-abhängigen Dehydrogenasen von exp. zu stat. Wachstumsphase deutlich an. Ethanol wird nach $8 \mathrm{~h}$ mit 5,4 U/mg und nach 24 h mit 16,2 U/mg umgesetzt, was einer Steigerung um den Faktor 3 entspricht. Die Steigerung mit Glycerol als Substrat ist mit dem Faktor 6,8 sogar doppelt so hoch, von $0,27 \mathrm{U} / \mathrm{mg}$ auf $1,83 \mathrm{U} / \mathrm{mg}$. Zumindest dieser Anstieg könnte mit der deutlichen Zunahme an ICM um den Faktor 3,4 im gleichen Zeitraum in Zusammenhang stehen. 
Beim Wachstum mit 0,5 M Mannitol steigt die spezifische Aktivität mit Ethanol und mit Glycerol als Substrat für die membranständigen, PQQ-abhängigen Dehydrogenasen von exp. zu stat. Wachstumsphase ebenfalls an, obwohl der Quotient ICM/Zelle um den Faktor 1,4 zurückgeht. Ethanol wird nach $8 \mathrm{~h}$ mit $13 \mathrm{U} / \mathrm{mg}$ und nach $24 \mathrm{~h} \mathrm{mit}$ 16,8 U/mg umgesetzt, eine Steigerung um den Faktor 1,3. Der Umsatz von Glycerol als Substrat steigt von 1,33 U/mg auf 2,02 U/mg um den Faktor 1,5.

Die spezifische Aktivität mit Glucose als Testsubstrat geht unter beiden Bedingungen zurück, beim Wachstum mit Glycerol um den Faktor 1,1 und beim Wachstum mit Mannitol um den Faktor 1,3. Mit Mannitol als Testsubstrat steigt die Aktivität bei der Anzucht auf Glycerol von $0 \mathrm{U} / \mathrm{mg}$ auf 0,2 U/mg, beim Wachstum mit Mannitol sinkt sie, entsprechend dem Rückgang an ICM, um den Faktor 1,7.

Ein genereller Zusammenhang zwischen ICM-Menge und der spezifischen Aktivität membranständiger, PQQ-abhängiger Dehydrogenasen scheint demnach nicht zu bestehen. Die Entwicklungen müssen daher einzeln für die jeweiligen Anzuchtbedingungen und für die Enzymaktivitätstests eingesetzten Substrate betrachtet werden. Beim Wachstum mit 0,5 M Glycerol steigt von exp. zur stat. Wachstumsphase die ICM-Menge, gleichzeitig steigen die spezifischen Enzymaktivitäten für den Umsatz von Ethanol, Glycerol und Mannitol. Beim Wachstum mit 0,5 M Mannitol sinkt die ICM-Menge im Verlauf von exp. zu stat. Wachstumsphase, während die spezifischen Enzymaktivitäten für den Umsatz von Ethanol und Glycerol leicht ansteigen. Der Umsatz von Mannitol geht in Korrelation mit der ICM-Menge leicht zurück. Gegenüber dem Testsubstrat Glucose ist unter beiden Bedingungen ein Rückgang der spezifischen Aktivität von exp. zur stat. Phase festzustellen.

Die Immunogold-Markierung mit dem Antikörper gegen die Polyol-Dehydrogenase weist nach $24 \mathrm{~h}$ Wachstum mit 0,5 M Glycerol ca. doppelt so viele markierte Positionen an der Cytoplasmamembran auf als nach $8 \mathrm{~h}$. Dies könnte den starken Anstieg der spezifischen Enzymaktivität gegenüber Glycerol als Testsubstrat um den Faktor 6,8 im gleichen Zeitraum erklären. Beim Wachstum mit 0,5 M Mannitol nimmt die Intensität der Immunogold-Markierung nur leicht zu und korreliert mit dem vergleichsweise moderaten Anstieg der spezifischen Enzymaktivität gegenüber Glycerol von exp. zur stat. Wachstumsphase um den Faktor 1,5. Die Immunogold-Markierungen deuten somit auf einen direkten Zusammenhang zwischen den ermittelten spezifischen Enzymaktivitäten und der Anzahl an markierten Dehydrogenasen hin. Allerdings spricht die im Vergleich schwache Markierung nach $8 \mathrm{~h}$ Wachstum mit Mannitol 
$(1,33 \mathrm{U} / \mathrm{mg})$ gegenüber der nach $8 \mathrm{~h}$ Wachstum mit Glycerol $(0,27 \mathrm{U} / \mathrm{mg})$ gegen eine lineare Beziehung zwischen der Markierung und der Enzymaktivität. Daher ist ein Einfluss des zur Anzucht benutzten Substrats auf die Aktivität und Expression der Polyol-Dehydrogenase nicht auszuschließen. Glycerol kann das Wachstum von $G$. oxydans stören, vielleicht führt Glycerol oder das durch Oxidation erhaltene Produkt Dihydroxyaceton (DHA) zu einer Einschränkung des Substratumsatzes der PolyolDehydrogenase, auf den der Organismus mit einer erhöhten Expression reagiert. Eine inhibierende Wirkung von DHA auf eine $\mathrm{NAD}^{+}$-abhängige Glycerol-Dehydrogenase in Klebsiella oxytoca ist von STRICKLAND und MILLER (1968) beschrieben worden. Demgegenüber konstatieren BAUER et al. (2005) einer für die Glycerol-Oxidation verantwortlichen membranständigen Dehydrogenase auch bei hohen DHAKonzentrationen Aktivität. Diese wurde aber nicht für das Enzym an sich, sondern für Zellkulturen ermittelt, die infolge der hohen DHA-Konzentrationen irreversibel wachstumsgehemmt, bzw. bereits lysiert waren. In diesen Zellen könnte die Anzahl an Polyol-Dehydrogenasen ebenfalls sehr hoch sein und zu der per HPLC gemessenen Produktbildung führen.

Die spezifischen Enzymaktivitäten gegenüber dem Substrat Mannitol sind sehr gering. Sie sind aber mit den Immunogold-Markierungen der Polyol-Dehydrogenase, die Mannitol zu Fructose oxidiert, gut in Einklang zu bringen. Die deutlich intensivere Markierung der Polyol-Dehydrogenase beim Wachstum mit Glycerol in der exp. Wachstumsphase ist eine gute Erklärung für die erst zu diesem Zeitpunkt messbare Aktivität gegenüber Mannitol als Testsubstrat. Der leichte Rückgang der spezifischen Enzymaktivität beim Wachstum mit Mannitol von exp. zu stat. Wachstumsphase muss mit der kaum veränderten Intensität der Markierung der Polyol-Dehydrogenase im gleichen Zeitraum nicht im Widerspruch stehen. Das Substratspektrum der PolyolDehydrogenase ist groß, Anteile des Hefeextrakts könnten weiterhin oxidiert werden. Eine mögliche Regulation der Enzymaktivität durch intra- oder extrazelluläre Fructose erscheint ebenfalls vorstellbar.

Zwischen dem Anteil an Zellen, die ICM enthalten und der spezifischen Aktivität membranständiger, PQQ-abhängiger Dehydrogenasen besteht kein genereller Zusammenhang. Demgegenüber scheint die Anzahl an Immunogold-markierten Dehydrogenasen mit den ermittelten spezifischen Enzymaktivitäten zu korrelieren. 


\subsubsection{Besteht ein direkter Zusammenhang zwischen} Substratkonzentration und spezifischer Aktivität membranständiger Dehydrogenasen?

Um dies zu untersuchen, werden im Folgenden die spezifischen Enzymaktivitäten und der Anteil an Zellen mit ICM in der exp. und der frühen stat. Wachstumsphase bei Substratkonzentrationen von 0,1 M Mannitol und 0,5 M Mannitol miteinander verglichen. Die spezifische Enzymaktivität wurde für membranständige Dehydrogenasen gemessen, die aus Kulturen stammen, die unter Standardbedingungen mit 0,11 M Mannitol angezogen wurden (Kap. 3.3). Der Anteil an Zellen, die ICM enthalten ist dagegen anhand einer Kultur ermittelt worden, die mit 0,1 M Mannitol angezogen wurde (Kap. 3.2.2.). Ein kurzer Vergleich der Wachstumsparameter und Zeitpunkte der Probennahme von exp. und stat. Wachstumsphase erlaubt die Zusammenfassung der Daten: Die max. Wachstumsrate der Kulturen beim Wachstum mit 0,11 M (Standard Mannitol-Medium) betrug 0,46/h. Die Proben für die Enzymaktivitätstests wurden nach 6,75 h inmitten der exp. Wachstumsphase und nach $16 \mathrm{~h}$ in der frühen stat. Wachstumsphase genommen. Der Anteil an Zellen, die ICM enthalten wurde mit Kulturen ermittelt, deren Anzucht mit 0,1 M Mannitol erfolgte, wobei hier die max. Wachstumsrate $0,39 / \mathrm{h}$ betrug. Die Proben wurden nach $8 \mathrm{~h}$ inmitten der exp. Wachstumsphase und nach $24 \mathrm{~h}$ in der frühen stat. Wachstumsphase genommen. Da die Bedingungen der beiden Wachstumsversuche also recht ähnlich waren, sind die Versuchsergebnisse gut miteinander zu vergleichen. (Abb. 3.3.1 und Abb. 3.2.5.). Die Zeitpunkte der Probennahme liegen inmitten der exp. Wachstumsphase, bzw. ca. $6 \mathrm{~h}$ nach dem Übergang und somit in der ,frühen" stat. Wachstumsphase. Die Daten für das Wachstum mit 0,5 M Mannitol sind im Kap. 3.2.2. vorgestellt und wurden unter vergleichbaren Bedingungen ermittelt.

Bei dem Wachstum mit 0,1 M Mannitol hat sich der Anteil an Zellen, die ICM enthalten von der exp. (8 h) zu früher stat. Wachstumsphase $(24 \mathrm{~h})$ von $2,15 \%$ auf $4,92 \% \mathrm{mehr}$ als verdoppelt (Abb. 3.2.7). Da die Standardabweichung der 24 h-Probe jedoch groß ist, könnte der Anstieg in diesem Fall auch deutlich über oder unter diesem Mittelwert liegen. Die spezifische Aktivität membrangebundener, PQQ-abhängiger Dehydrogenasen ist für die getesteten Substrate Ethanol, Glucose, Glycerol und Mannitol in der stat. Wachstumsphase niedriger als in der exp. Wachstumsphase (Abb. 3.3.2.). Die höchsten spezifischen Aktivitäten wurden für alle getesteten Substrate 
an dem Zeitpunkt des Übergangs von exp. zur stat. Wachstumsphase nach 9,5 h gemessen. In diesem Fall ist ein direkter Zusammenhang zwischen dem gehäuften Auftreten von ICM und einem Anstieg der Enzymaktivität nicht zu erkennen, es ist eher ein gegenläufiger Prozess zu beobachten. Die Abb. 3.1.4. zeigt Immunogold-markierte Zellen von G. oxydans $621 \mathrm{H}$, die mit Standard Mannitol-Medium über $8 \mathrm{~h}$ und $24 \mathrm{~h}$ angezogen worden sind. Die Intensität der Markierung ist nach $8 \mathrm{~h}$ höher als nach $24 \mathrm{~h}$. Diese schwächere Expression könnte den leichten Rückgang der spezifischen Enzymaktivität für die getesteten Substrate der Polyol-Dehydrogenase Mannitol und Glycerol erklären.

Bei dem Wachstum mit 0,5 M Mannitol geht der Anteil an Zellen, die ICM enthalten von der exp. (8 h) zu früher stat. Wachstumsphase (24 h) von 5,45\% auf 4,02\% zurück (Abb. 3.2.7). Die relativ geringe Standardabweichung beider Proben lässt auf eine reproduzierbare Ausnahme der Regel schließen, dass hier der Anteil an Zellen, die ICM enthalten von exp. zu stat. Wachstumsphase geringer wird. Im Gegensatz zum Wachstum mit 0,1 M Mannitol steigt die spezifische Aktivität membrangebundener PQQ-abhängiger Dehydrogenasen mit Ethanol und Glycerol als Testsubstrat von exp. zu stat. Wachstumsphase an, während sich die spezifische Aktivität mit Glucose und Mannitol als Substrat verringert. Ein direkter Zusammenhang zwischen der ICM-Menge und der Aktivität membranständiger, PQQ-abhängiger Dehydrogenasen ist demnach nicht zu erkennen. Die Stärke der Immunogold-Markierung ist mit 0,5 M Mannitol nach $8 \mathrm{~h}$ Wachstum etwas schwächer als nach $24 \mathrm{~h}$ (Abb. 3.2.11.) und könnte somit den Anstieg der spezifischen Enzymaktivität gegenüber dem Testsubstrat Glycerol erklären (siehe auch Kap. 4.3.1).

Mit Ausnahme von Ethanol als Testsubstrat sind die spezifischen Enzymaktivitäten beim Wachstum mit 0,11 M Mannitol höher als mit 0,5 M Mannitol, dies gilt für die exp. und stat. Wachstumsphase. Ein direkter Vergleich der Immunogold-Markierung nach $8 \mathrm{~h}$ Wachstum zeigt, dass mit $0,11 \mathrm{M}$ eine deutlich höhere Intensität erreicht wird als mit 0,5 M. Nach $24 \mathrm{~h}$ ist die Intensität der Markierung unter beiden Bedingungen ähnlich, während sich auch die Enzymaktivitäten für die Substrate Glycerol und Mannitol einander angleichen.

Ein ähnlicher Vergleich mit Glycerol ist aufgrund fehlender Daten zur Enzymaktivität mit Standard Glycerol-Medium hier nicht möglich. Gänzlich unerwähnt lassen sollte man die vorhandenen Immunogold-Markierungen und den ermittelten Quotienten ICM/Zelle allerdings nicht, zumal sich ein gut reproduzierbarer Zusammenhang 
zwischen den Markierungen und den Enzymaktivitäten abzeichnet. Die Anzahl an Zellen, die ICM enthalten scheint keinen Einfluss auf die Enzymaktivität zu haben. Im Verlauf des Wachstums mit 0,5 M Glycerol steigen sowohl die spezifische Enzymaktivität gegenüber den Testsubstraten Glycerol und Mannitol (Abb. 3.2.8.) als auch die Intensität der Immunogold-Markierung der Polyol-Dehydrogenase (Abb. 3.2.10.) von exp. zu stat. Wachstumsphase an. In diesem Fall ist auch eine Zunahme an Zellen, die ICM enthalten zu beobachten (Abb. 3.2.7.).

Beim Wachstum mit 0,1 M Glycerol nimmt der Anteil an Zellen, die ICM enthalten von exp. zu stat. Wachstumsphase ebenfalls zu (Abb. 3.2.7.), die Immunogold-Markierung ist dagegen nach $8 \mathrm{~h}$ etwas stärker als nach $24 \mathrm{~h}$ (Abb. 3.1.4.). Die vorliegenden Daten lassen die Prognose zu, dass ähnlich dem Wachstum mit 0,11 M Mannitol hier ebenfalls ein Rückgang der Enzymaktivität gegenüber den Substraten Glycerol und Mannitol zu erwarten ist, weil die Intensität der Immunogold-Markierung im gleichen Zeitraum nachlässt, und man den Anstieg des Anteils an Zellen, die ICM enthalten in diesem Zusammenhang vernachlässigen kann.

Beim Wachstum mit geringer Mannitol-Konzentration sind in der exp. Wachstumsphase die spezifischen Enzymaktivitäten höher und die ImmunogoldMarkierungen intensiver als beim Wachstum mit höherer MannitolKonzentration. In der stat. Wachstumsphase gleichen sich sowohl die Intensität der Markierung als auch die Enzymaktivitäten für die Substrate Glycerol und Mannitol einander an. Die hier diskutierten Beobachtungen lassen den Schluss zu, dass beim Wachstum mit geringer Glycerol im Verlauf des Wachstums ebenfalls ein Rückgang der Aktivitäten zu erwarten ist.

\subsection{G. oxydans $621 \mathrm{H}$ bei verringertem Sauerstoffeintrag}

Bei der Anzucht von Mikroorganismen als Flüssigkulturen in Erlenmeyerkolben ist davon auszugehen, dass sich durch eine langsamere Rotationsgeschwindigkeit der Kolben ein geringerer Sauerstoffpartialdruck im Medium einstellt (SCHIEFELBEIN et al., 2013). Beim Wachstum von G. oxydans $621 \mathrm{H}$ mit 50 upm sinkt die max. Wachstumsrate im Vergleich mit der Standardanzucht mit 200 upm von 0,46/h auf 0,18/h um $60 \%$ und benötigt mit 24 h etwa doppelt so viel Zeit zum Erreichen der exp. 
Wachstumsphase. Die $\mathrm{OD}_{600}$ nach 48 h beträgt 2,53 und ist damit um $6 \%$ niedriger als die erreichte $\mathrm{OD}_{600}$ unter Standardbedingungen von 2,70. Die Anzucht von G. oxydans $621 \mathrm{H}$ bei der auf ein Viertel reduzierten Rotationsgeschwindigkeit kann zu einer signifikanten Steigerung der spezifischen Aktivität membranständiger Dehydrogenasen in der stat. Wachstumsphase gegenüber der exp. Wachstumsphase führen (Kap. 3.3.2.). Dieser Anstieg in der Enzymaktivität entspricht den von CLAUS et al. (1975) und WHITE und CLAUS (1982) gemachten Beobachtungen, dass in der stat. Wachstumsphase ein höherer Substratumsatz festzustellen ist als in der exp. Wachstumsphase. Unter verringertem Sauerstoffeintrag wird insbesondere das Substrat Mannitol von membranständigen, PQQ-abhängigen Dehydrogenasen in der stat. Wachstumsphase stärker umgesetzt. Die spezifische Aktivität gegenüber Mannitol steigt im Vergleich zur exp. Wachstumsphase um den Faktor 8,3. Mit den Substraten Ethanol (Faktor 1,8), Glucose (Faktor 1,4) und Glycerol (Faktor 3) waren nach 24 h ebenfalls höhere Aktivitäten als nach $8 \mathrm{~h}$ messbar. Unter Standardbedingungen gehen in der stat. Wachstumsphase die Aktivitäten gegenüber allen Substraten zurück, verglichen mit der exp. Wachstumsphase.

Die Western Blot-Analyse mit dem Antikörper gegen die große Untereinheit der membranständigen Polyol-Dehydrogenase zeigt, dass eine verstärkte Expression der Polyol-Dehydrogenase der Grund für den Anstieg der spezifischen Enzymaktivität gegenüber den Substraten Glycerol und Mannitol sein kann (Abb. 3.3.4.). Die Expression ist bei verringertem Sauerstoffeintrag nach $30 \mathrm{~h}$ Wachstum etwas stärker als nach $8 \mathrm{~h}$ Wachstum. Die insgesamt stärkste Expression ist unter Standardbedingungen nach $8 \mathrm{~h} \mathrm{zu}$ erkennen, nach $30 \mathrm{~h}$ ist die Expression deutlich geringer. Beim Vergleich der jeweils kräftigsten Banden beider Bedingungen und den dazu gehörenden spezifischen Enzymaktivitäten fällt auf, dass trotz der deutlich stärkeren Expression nach $8 \mathrm{~h}$ unter Standardbedingungen die Aktivitäten nicht höher sind als nach $30 \mathrm{~h}$ unter Sauerstoffmangel. Nach $8 \mathrm{~h}$ unter Standardbedingungen entsprechen die spezifischen Aktivitäten gegenüber Glycerol mit 3,2 U/mg und Mannitol mit 0,8 U/mg (Abb. 3.3.2.) denen unter verringertem Sauerstoffeintrag nach $30 \mathrm{~h}$ von $3,3 \mathrm{U} / \mathrm{mg}$ und $0,8 \mathrm{U} / \mathrm{mg}$ (Abb. 3.3.3.). Eine im Western Blot außergewöhnlich starke Expression führt nicht zwangsläufig zu einer besonders hohen Enzymaktivität. Es hat den Anschein, dass nicht alle exprimierten Polyol-Dehydrogenasen letztendlich in die Cytoplasmamembran eingefügt werden und dort zur spezifischen Enzymaktivität beitragen. Anhand der Immunogold-Markierungen der Polyol-Dehydrogenase lassen sich die 
Enzymaktivitäten gegenüber Glycerol und Mannitol besser erklären als mit dem Western Blot (Abb. 3.3.5. und 3.3.6). Die jeweils intensivsten Markierungen sind nach $8 \mathrm{~h}$ Wachstum bei Standardbedingungen sowie nach $24 \mathrm{~h}$ bei verringertem Sauerstoffeintrag zu erkennen, also ungefähr zu den Zeitpunkten, in denen jeweils auch die höheren spezifischen Enzymaktivitäten gemessen werden konnten. Im Gegensatz zu den Signalen im Western Blot sind die Immunogold-Markierungen in etwa gleich stark und spiegeln die fast identischen Enzymaktivitäten wieder.

Vergleicht man die Werte der spezifischen Aktivitäten insgesamt, so scheinen diese unter Sauerstoffmangel lediglich in die stat. Wachstumsphase verschoben zu sein. Wie bereits erwähnt wurde, sind die Werte von exp. Wachstumsphase unter Standardbedingungen und stat. Wachstumsphase bei verringertem Sauerstoffeintrag für alle Substrate ähnlich, ausgenommen Ethanol (Glucose: 4,7 U/mg und 4,4 U/mg; Glycerol: 3,2 U/mg und 3,3 U/mg; Mannitol: beide 0,8 U/mg). Darüber hinaus gelten für alle genannten Substrate unter beiden Bedingungen, dass die höchsten Werte während des Zeitpunktes des Übergangs von exp. zur stat. Wachstumsphase ermittelt werden können (Kap. 3.3.1 und Kap. 3.3.2). Die Werte gegenüber Ethanol als Substrat verhalten sich ein wenig anders und werden im Kap. 1.4.1 gesondert betrachtet.

Die Anzucht von G. oxydans bei verringertem Sauerstoffeintrag führt in der stat. Wachstumsphase zu einer signifikanten Steigerung der spezifischen Aktivität membranständiger Dehydrogenasen im Vergleich zur exp. Wachstumsphase. Allerdings werden die erhöhten Werte unter Sauerstoffmangel lediglich von der exp. in die stat. Wachstumsphase verschoben. Die höchsten Werte werden sowohl unter Standard-, als auch unter Sauerstoffmangelbedingungen während des Übergangs von exp. zur stat. Wachstumsphase erreicht.

\subsubsection{Die Enzymaktivität PQQ-abhängiger, membranständiger Dehydrogenasen gegenüber dem Substrat Ethanol}

Ausgenommen von der in Kap. 1.4 gewonnenen Erkenntnis, dass die insgesamt höchste spezifische Aktivität an dem Zeitpunkt des Übergangs von exp. zur stat. Wachstumsphase messbar ist und sich durch das Wachstum bei verringertem Sauerstoffeintrag keine neuen, absoluten Höchstwerte erreichen lassen, ist das Substrat 
Ethanol. In dem Fall liegt der absolute Höchstwert unter verringertem Sauerstoffeintrag in der stat. Wachstumsphase, der auch unter Standardbedingungen während des Übergangs von exp. zur stat. Wachstumsphase nicht erreicht wird.

Der Anstieg der spezifischen Aktivität gegenüber dem Substrat Ethanol könnte mit der intrazellulären Reduktion von Acetaldehyd $\mathrm{zu}$ Ethanol durch die AlkoholDehydrogenasen GOX0313 oder GOX0314 zusammenhängen. Zusammen mit der NAD(P)-abhängigen Transhydrogenase (GOX0310 bis GOX0312) weisen die entsprechenden Gene eine stark erhöhte Transkriptionsrate von 10,3 bis 14,6 unter Sauerstoffmangel auf und bilden wahrscheinlich ein Operon. Eine Reduktion von Acetaldehyd zu Ethanol könnte in dem Bedarf der Regeneration von $\mathrm{NAD}(\mathrm{P})^{+}$unter Sauerstoffmangel begründet sein (HANKE et al., 2012). Unter den gleichen Bedingungen wurde eine stark gesteigerte Transkriptionsrate von GOX0815 (6,5) und GOX0647 (18,2) festgestellt. Für diese Proteine wird angenommen, dass sie in den Transport, bzw. den Export involviert sind. Angenommen, sie würden Ethanol aus der Zelle in das Periplasma und damit in das umgebende Medium abgeben, könnte dies zum einen das Wachstum von Konkurrenten beeinträchtigen. Im Allgemeinen können Gluconobacter-Arten bei einer Ethanol-Konzentration von $5 \%$ wachsen, sind aber in Wein mit bis zu 14 \% Ethanol noch lebensfähig (DU TOIT und PRETORIUS, 2002). Zum anderen könnte das Ethanol im Periplasma durch membranständige, PQQabhängige Dehydrogenasen zu Acetaldehyd (GOX1067/1068) und dieses anschließend $\mathrm{zu}$ Acetat (GOX0585-GOX0587) oxidiert werden. Zusammen mit der Transhydrogenase wären der Aufbau eines Protonengradienten und eine damit einhergehende ATP-Synthese eine gute Strategie, um unter Sauerstoffmangel leben und wachsen zu können.

Gegenüber Ethanol als Testsubstrat konnte unter Sauerstoffmangel in der stat. Wachstumsphase die höchste spezifische Enzymaktivität gemessen werden. Dies könnte durch eine Umstellung der Verwertung von Ethanol unter diesen Bedingungen erklärt werden. 


\subsubsection{Die Rolle der Quinol-Oxidase des bo3-Typs GOX1911-1914}

Wie kann erklärt werden, dass membranständige Dehydrogenasen in der stat. Wachstumsphase eine spezifische Aktivität aufweisen können, die mit den unter Standardbedingungen ermittelten Werten vergleichbar sind, wenn die Menge des verfügbaren terminalen Elektronenakzeptors Sauerstoff reduziert ist? Eine mögliche Reaktion des Organismus wäre, die Affinität bezüglich des vorhandenen Sauerstoffs zu erhöhen, um diesen optimal verwerten zu können. Eine erhöhte Menge an terminalen Quinol-Oxidasen könnten Elektronen aus dem Quinol-Pool effektiver auf den in geringerer Konzentration verfügbaren Sauerstoff übertragen. Die Arbeiten von HANKE et al. (2012) bestätigen diese Vorstellung; unter Sauerstoffmangel wurde eine erhöhte Transkriptionsrate für die Gene der Quinol-Oxidase des b03-Typs gox1911 bis gox1914 festgestellt. Das Verhältnis der Transkription unter den Bedingungen von Sauerstoffmangel zu Sauerstoffsättigung liegt zwischen 2,7 und 3,8.

Diese Ergebnisse konnten in dieser Arbeit auf translationaler Ebene mittels Western Blot mit dem Antikörper gegen GOX1912 bestätigt werden (Abb. 3.3.7.). Unter verringerter Sauerstoffkonzentration ist GOX1912 nach $30 \mathrm{~h}$ Wachstum in der stat. Wachstumsphase insgesamt am stärksten exprimiert, im Vergleich mit der exp. Wachstumsphase nach $8 \mathrm{~h}$ etwa doppelt so stark. Unter Standardbedingungen ist die Expression nach $8 \mathrm{~h}$ Wachstum in der exp. Wachstumsphase stärker als nach $30 \mathrm{~h}$ in der stat. Wachstumsphase, hier ist sie insgesamt am schwächsten. Die ImmunogoldMarkierung mit dem Antikörper gegen GOX1912 bestätigen diese Ergebnisse, auch wenn die Unterschiede in der Markierung nicht so signifikant sind wie im Western Blot (Abb. 3.3.8. und 3.3.9). Hier ist die Intensität bei verringerter Sauerstoffkonzentration nach $24 \mathrm{~h}$ Wachstum in der stat. Wachstumsphase insgesamt am stärksten und unter Standardbedingungen ist die Intensität der Markierung nach $8 \mathrm{~h}$ höher als nach $24 \mathrm{~h}$.

Die unter Sauerstofflimitierung im Verlauf des Wachstums gesteigerten spezifischen Aktivitäten werden aber nicht direkt auf die erhöhte Expression der Quinol-Oxidase zurückzuführen sein. Eine gesteigerte Expression könnte sich nicht nur auf die terminalen Oxidasen beschränken, sondern auch weitere Enzyme betreffen, die an den unvollständigen Oxidationen beteiligt sind. Gegen diese Vorstellung spricht zunächst, dass die Transkriptionsrate der membranständigen Polyol-Dehydrogenase GOX0854/0855 unter Sauerstoffmangel im Verhältnis zu Sauerstoffsättigung um den Faktor 10 sinkt (HANKE et al., 2012). Der Western Blot mit dem Antikörper gegen die große Untereinheit der Polyol-Dehydrogenase zeigt nach $30 \mathrm{~h}$ Wachstum bei 
vermindertem Sauerstoffeintrag eine etwas stärkere Bande als nach $8 \mathrm{~h}$ Wachstum (Abb. 3.3.4.). Die Intensität der Immunogold-Markierung ist nach $30 \mathrm{~h}$ Wachstum bei 50 upm ebenfalls stärker als nach $8 \mathrm{~h}$ (Abb. 3.3.5. und 3.3.6.). Die verringerte Transkription, welche unter Sauerstoffmangel zunächst auch sinnvoll erscheint, führt nicht zu einer verminderten Menge an aktiver Polyol-Dehydrogenase. Im Gegenteil, der leichte Anstieg der Menge an Polyol-Dehydrogenase von exp. zur stat. Wachstumsphase kann die Erklärung für die im Vergleich zur exp. Wachstumsphase erhöhten spezifischen Aktivitäten gegenüber den Testsubstraten Glycerol und Mannitol in der stat. Wachstumsphase sein.

Der entscheidende Hinweis auf einen Zusammenhang zwischen der Expression von Oxidase und Dehydrogenase ist die Entwicklung der Expression der PolyolDehydrogenase in der Deletionsmutante, der die Quinol-Oxidase des bo3-Typs fehlt. Eine auffällig stärkere Expression wie beim Wildtyp nach $8 \mathrm{~h}$ Wachstum unter Standardbedingungen tritt in diesem Fall nicht auf. Die Expression von GOX0854 in der Deletionsmutante hat unter allen getesteten Bedingungen und Zeitpunkten eine ähnliche Intensität, lediglich nach $30 \mathrm{~h}$ Wachstum bei verringertem Sauerstoffeintrag ist sie etwas schwächer. Beim Wildtyp ist sie unter den gleichen Bedingungen zum gleichen Zeitpunkt am stärksten. Dies könnte auf einen Einfluss der Quinol-Oxidase, bzw. des Elektronenflusses durch die kurze Elektronentransportkette (Kap. 1.4), auf die Expression der membranständigen Polyol-Dehydrogenase hindeuten. Wenn Elektronen auf Ubichinon übertragen werden und das entstandene Quinol rasch von einer QuinolOxidase oxidiert wird führt das $\mathrm{zu}$ einer verstärkten Expression der PolyolDehydrogenase, wie im Fall des Wildtyps nach $8 \mathrm{~h}$ Wachstum unter Standardbedingungen. Unter Sauerstoffmangel steigt die Expression der QuinolOxidase von der exp. zur stat. Wachstumsphase stark an, was einen Anstieg der PolyolDehydrogenase im gleichen Zeitraum zur Folge hat. In der Deletionsmutante ist kein derartiger regulatorischer Effekt mehr vorhanden, die Expression der Polyoldehydrogenase ist relativ konstant.

Eine Möglichkeit diesen Effekt zu untersuchen, bzw. für die biotechnologische Anwendung nutzbar zu machen, wäre die Überexpression einer der Quinol-Oxidasen. Dies könnte das Potential der membranständigen Dehydrogenasen steigern, oder zu deren gesteigerten Expression führen. Die Unterstützung artifizieller Überexpressionen von membranständigen Dehydrogenasen wäre eine weitere Möglichkeit, um die Produktausbeute zu verbessern. Im Rahmen dieser Arbeit wurde versucht, die Quinol- 
Oxidase des bo3-Typs (GOX1911-GOX1914) durch eine Klonierung der entsprechenden Gene in die Plasmide pBBR1p264, pBBR1p384 und pBBR1p452 ektopisch in Wildtyp und Deletionsmutante zu exprimieren. Dieser Ansatz scheiterte aber bei dem Versuch, die im Prinzip fertig konstruierten Plasmide via Elektroporation in die entsprechenden G. oxydans-Stämme zu transformieren (Daten nicht gezeigt).

Die Quinol Oxidase des b03-Typs wird bei G. oxydans unter Sauerstoffmangel stärker exprimiert als unter Standardbedingungen und erklärt somit den Verbleib von Elektronen, die durch unvollständige Oxidationen unter Sauerstoffmangel unvermindert entstehen. Ein Rückgang an exprimierter Polyol-Dehydrogenase ist unter Sauerstoffmangel nicht zu beobachten, da der Elektronenfluss durch die kurze Elektronentransportkette aufrecht erhalten wird.

\subsection{ICM in G. oxydans und ihr Potential in der Biotechnologie}

Das in der Arbeit von CLAUS et al. (1975) benutzte Medium enthielt Glycerol in einer Konzentration von $0,54 \mathrm{Mol} / 1$. Die Rotationsgeschwindigkeit und das Füllvolumen der Erlenmeyerkolben entsprachen den hier vorgestellten Standardbedingungen, lediglich die Temperatur war mit $28{ }^{\circ} \mathrm{C}$ etwas niedriger. Somit sind diese Anzuchtbedingungen mit dem im Rahmen dieser Arbeit untersuchten Wachstum von G. oxydans mit 0,5 M Glycerol als Substrat vergleichbar (Kap. 3.2.2). Hierbei steigt der Anteil von Zellen, die ICM enthalten von exp. zu stat. Wachstumsphase um den Faktor 3,4 und gleichzeitig steigt die spezifische Enzymaktivität um den Faktor 6,8. Darüber hinaus ist die Immunogold-Markierung der Polyol-Dehydrogenase in der stat. Wachstumsphase doppelt so intensiv wie in der exp. Wachstumsphase. Es scheint unter den beschriebenen Bedingungen einen direkten Zusammenhang zwischen ICM-Menge, exprimierter Dehydrogenase und der spezifischen Enzymaktivität zu geben. Dies stimmt mit den von CLAUS et al. (1975) gemachten Beobachtungen überein, die eine erhöhte ICM-Menge mit einer erhöhten Respirationsrate und der verstärkten Bildung von Dihydroxyaceton in Verbindung brachten.

In dieser Arbeit wurde ein Mannitol-Medium mit einer Substratkonzentration von 0,11 M zur Standardanzucht verwendet, wie es auch von unseren Kooperationspartnern der Universität Bonn benutzt wird (KALLNIK et al., 2010; MEYER et al., 2013). Bei 
dem Wachstum unter Standardbedingungen hat sich der Anteil an Zellen, die ICM enthalten von der exp. zu stat. Wachstumsphase mehr als verdoppelt. Die spezifische Aktivität membrangebundener, PQQ-abhängiger Dehydrogenasen ist dagegen gegenüber allen im Rahmen dieser Arbeit getesteten Substrate Ethanol, Glucose, Glycerol und Mannitol in der stat. Wachstumsphase niedriger als in der exp. Wachstumsphase. Das Signal im Western Blot und die Immunogold-Markierung der Polyol-Dehydrogenase sind nach 8 h Wachstum ebenfalls stärker als nach 24 h. Beim Wachstum mit 0,5 M Mannitol war trotz eines Rückgangs des Anteils an Zellen, die ICM enthalten sogar ein leichter Anstieg der spezifischen Enzymaktivität gegenüber Glycerol als Substrat messbar, während die Intensität der Immunogold-Markierung der Polyol-Dehydrogenase ebenfalls leicht zunahm. Somit gibt es keinen direkten Zusammenhang zwischen dem Anteil an Zellen, die ICM enthalten und den spezifischen Aktivitäten membranständiger, PQQ-abhängiger Dehydrogenasen gegenüber der im Rahmen dieser Arbeit getesteten Substrate. Wenn hohe Aktivitäten gemessen wurden, dann lag dies im Falle der Substrate Glycerol und Mannitol an einer erhöhten Anzahl an Dehydrogenasen, die in der Cytoplasmamembran (CM) lokalisiert sind.

Die höchsten im Rahmen dieser Arbeit vorgestellten Enzymaktivitäten wurden, Ethanol als Testsubstrat ausgenommen, unter Standardbedingungen mit Standard-Medium während des Übergangs von exp. zu stat. Wachstumsphase gemessen (Abb. 3.3.2). Die ICM-Menge ist zu diesem Zeitpunkt nicht besonders hoch, verglichen mit allen anderen Zeitpunkten und Bedingungen, darunter auch die mit 0,5 M Substrat oder bei Sauerstoffmangel. Unabhängig von dem zur Anzucht benutzten Substrat, dessen Konzentration oder der Konzentration des im Medium gelösten Sauerstoffs, scheinen die höchsten Aktivitäten immer während des Übergangs von exp. zu stat. Wachstumsphase aufzutreten. Die im Vergleich zur Standardanzucht geringeren max. Wachstumsraten, die bei der Anzucht mit verringerter Sauerstoffkonzentration, dem Wachstum mit 0,5 M Mannitol oder Glycerol ermittelt wurden, könnten diesen Übergang über einen längeren Zeitraum ausdehnen. Der Zeitpunkt der Probennahme nach $24 \mathrm{~h}$ Wachstum liegt beim Wachstum mit 0,5 M Mannitol bereits einige Zeit nach dem Übergang von exp. zur stat. Wachstumsphase (Abb. 3.2.5.). Der Anstieg der Aktivität in der stat. Wachstumsphase gegenüber der exp. Wachstumsphase ist schwächer als beim Wachstum mit 0,5 M Glycerol. Hier hat die Kultur nach $24 \mathrm{~h}$ Wachstum den Übergang in die stat. Wachstumsphase gerade abgeschlossen (Abb. 
3.2.6.). Das Wachstum mit $0,5 \mathrm{M}$ Glycerol verläuft ohnehin stark verzögert. Der z. T. deutliche Anstieg der Aktivitäten zwischen der 8 h- und der 24 h-Probe könnte zum einen in dem frühen Stadium des Wachstums nach $8 \mathrm{~h}$ begründet sein. Zum anderen wurden die 24 h-Proben kurz nach oder während des Übergangs zur exp. Wachstumsphase genommen. Vielleicht ist es möglich, sich diesen ausgedehnten Bereich im Rahmen der biotechnologischen Anwendung nutzbar zu machen. Bei den in dieser Arbeit vorgestellten Versuchen zum Sauerstoffmangel ist das Wachstum auch verzögert (Abb. 3.3.1.), die spezifische Aktivität im Zeitraum vom Übergang nach ca. $16 \mathrm{~h}$ und der stat. Wachstumsphase liegt auf ähnlich hohem Niveau (Abb. 3.3.3.). Es werden zwar nicht die Spitzenwerte wie unter Standardbedingungen erreicht, dennoch könnte in Anlehnung an eine zeitliche Integration insgesamt eine effektivere Produktbildung erfolgen.

Welche Rolle könnten nun die ICM bei einer Optimierung von G. oxydans für die biotechnologische Anwendung spielen? Eine Grundvoraussetzung wäre zunächst ein Kontakt der ICM mit dem Periplasma und somit auch mit der Umgebung der Zelle, damit Substrate zu den Dehydrogenasen in der ICM gelangen können. Dass ICM aus der CM durch Invagination hervorgehen konnte aber mit keinem der zahlreich angefertigten TEM-Mikrographien belegt werden. Es wurde auch nie ein vom Periplasma ausgehender oder mit dem Periplasma in Kontakt stehender Bereich von ICM oder ICM-Vesikeln beobachtet. Die Ergebnisse dieser Arbeit deuten eher auf eine Entstehung von ICM-Vesikeln an der CM hin, die innerhalb des Cytoplasmas stattfindet (Kap. 1.2.1). Um den Kontakt der ICM oder der ICM-Vesikel mit dem Periplasma nachzuweisen, müssten intensivere elektronenmikroskopische Untersuchungen durchgeführt werden. Entweder kann das Hervorgehen der ICM durch Invagination doch noch dargestellt werden, oder es ist möglich, durch die Immunogold-Markierung von im Periplasma lokalisierten Enzymen in den ICM-Vesikeln deren Kontakt zur Umgebung zu belegen. Neben ihrer nach wie vor ungeklärten Funktion kommen ICM in G. oxydans nicht sehr häufig vor; maximal $10 \%$ der Zellen einer Kultur enthalten ICM (Abb. 3.2.6.). Eine entscheidende, für den Organismus vorteilhafte Funktion der ICM wie im Falle der fakultativ photosynthetischen Mikroorganismen, deren Pigmentsysteme sich in den Membranen der ICM-Vesikel befinden, scheint es für die ICM in G. oxydans nicht zu geben. Andernfalls würde wohl ein größerer Anteil an Zellen mit ICM in den entsprechenden Kulturen auftreten. Hinweise auf eine 
Wachstumsstörung oder ein Anzeichen von irregulärem Wachstum durch das Alter der Kultur oder einer Akkumulation cytotoxischer Substanzen wurden allerdings auch nicht gefunden. Die Zellen mit ICM scheinen intakt und lebensfähig zu sein.

Neben diesen Resultaten gibt es aber auch Hinweise auf eine verstärkte ICM-Bildung bei der Überexpression der Polyol-Dehydrogenase. Im Falle des Stammes G. oxydans

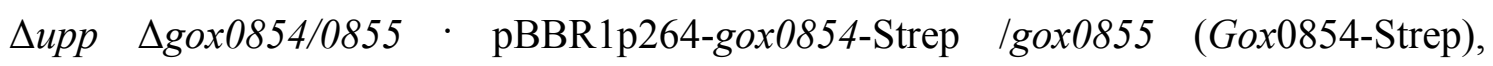
konnten markierte ICM dargestellt werden (Abb. 3.1.8.). Ob dieser Stamm möglicherweise eine gesteigerte Anzahl an Zellen, die ICM enthalten hervorbringt, ist mittels der im Rahmen dieser Arbeit angewandten Statistik zu überprüfen (2.6.3.3). Es wäre möglich, dass unter diesen speziellen Überexpressionsbedingungen eine vermehrte ICM-Bildung initiiert wird. Allerdings scheint eine hohe Menge an PolyolDehydrogenase nicht zwingend zu mehr ICM zu führen. Unter Standardbedingungen scheint die Menge an exprimierter Polyol-Dehydrogenase in der exp. Wachstumsphase größer zu sein als letztendlich in die CM eingebaut wird, um dort zum Substratumsatz beizutragen (Kap. 1.4). $\mathrm{Zu}$ diesem Zeitpunkt, nach $8 \mathrm{~h}$ Wachstum unter Standardbedingungen, ist die ICM-Menge nicht sehr hoch (Abb. 3.2.6.). Doch auch die Zunahme an ICM in der stat. Wachstumsphase führt weder zu einem Anstieg der Aktivität, noch zu einer erhöhten Menge an detektier- oder lokalisierbarer PolyolDehydrogenase. Es hat den Anschein, als wäre die Steigerung der ICM-Menge zur stat. Wachstumsphase in diesem Fall zunächst eine Reaktion auf die starke Expression von dieser oder mehreren membranständigen Dehydrogenasen in der exp. Wachstumsphase. In der stat. Wachstumsphase hat der Organismus dann aber wohl keinen Bedarf mehr an der Polyol-Dehydrogenase, deren Expression und die Enzymaktivität nehmen ab. Somit gibt es lediglich eine größere Menge an Zellen, die ICM enthalten. Wenn es gelänge, die Entwicklung der ICM mit dem Zeitpunkt der stärksten Expression der PolyolDehydrogenase zu synchronisieren, dann wäre eine effektivere Produktbildung durch mehr funktionsfähige Enzyme möglich. Vielleicht ist das langsame Wachstum mit weniger Sauerstoff bereits ein erster Schritt in diese Richtung. Ein stimulierender Einfluss der Quinol-Oxidase des Bo3-Typs oder des Elektronenflusses durch die kurze Elektronentransportkette auf die Expression der Polyol-Dehydrogenase ist in Kap. 4.4.2 diskutiert worden. Dieser Effekt gibt Grund zur Annahme, dass die alleinige Überexpression einer Quinol-Oxidase schon zu gesteigerten spezifischen Aktivitäten membranständiger Dehydrogenasen führen könnte. 
Es gibt keinen direkten Zusammenhang zwischen dem Anteil an Zellen, die ICM enthalten und den spezifischen Aktivitäten membranständiger, PQQ-abhängiger Dehydrogenasen gegenüber den hier getesteten Substraten. Der Umsatz von Glycerol und Mannitol ist abhängig von der Menge an Dehydrogenasen, die in der CM lokalisiert sind und die höchsten Enzymaktivitäten scheinen immer zum Zeitpunkt des Übergangs von exp. zu stat. Wachstumsphase aufzutreten. Die Synchronisierung der Zeitpunkte von starker Expression und gesteigerter ICMBildung könnte zu einer effektiveren Produktbildung führen, falls die ICM mit dem Periplasma in Kontakt stehen. Der stimulierende Einfluss der Quinol-Oxidase auf die Expression der Polyol-Dehydrogenase ist ein weiterer Ansatzpunkt, um die spezifischen Aktivitäten membranständiger Dehydrogenasen zu steigern. Darüber hinaus sollte der Stamm Gox0854-Strep hinsichtlich einer gesteigerten ICMBildung statistisch Untersucht werden.

\subsection{Das Monitoring membranständiger Dehydrogenasen mit fluoreszierenden membranständigen Fusionsproteinen}

Ziel war es, die Expression von membranständigen Dehydrogenasen während des Wachstums einer Kultur mittels eines fluoreszierenden Fusionsproteins zu verfolgen. Die Entwicklung eines Produktionsstammes, sowie die Untersuchung der optimalen Anzuchtbedingungen und die Überwachung des Produktionsstammes während der Fermentation wären mit fluoreszierenden Enzymen möglich (VAN ROESSEL und BRAND, 2002). In diesem Kapitel werden die Ergebnisse der Expression des auf dem Flavinmononukleotid basierenden fluoreszierenden Proteins (FbFP) und die Ergebnisse der ersten translationalen Fusion mit einer membranständigen Dehydrogenase diskutiert.

Das FbFP evoglowPp1 (egPp1) von der Fa. Evocatal wurde ausgewählt, weil seine Fluoreszenzstärke nicht von der zur Verfügung stehenden Sauerstoffmenge abhängt (DREPPER et al., 2010; MUKHERJEE et al., 2013). Es wurde gezeigt, dass besonders während der exponentiellen Wachstumsphase der Sauerstoffverbrauch einer wachsenden G. oxydans-Kultur sehr hoch sein kann (SILBERBACH et al., 2003; HANKE et al., 2012). FbFP wurde mit der membranständigen PQQ-abhängigen Dehydrogenase GOX1441 fusioniert, die nur aus einer Untereinheit besteht und mit 
$87,8 \mathrm{kDa}$ eine im Vergleich $\mathrm{zu}$ anderen vergleichbaren Enzymen geringe Größe aufweist (PRUST et al., 2005). Exprimiert wurden FbFP und das Fusionsprotein unter der Kontrolle der Promotoren, die ursprünglich die Expression der ribosomalen Proteine L35 (GOX0264), S12 (GOX0384) und L13 (GOX0452) kontrollieren (PRUST et al., 2005). Diese Promotoren sind vermutlich konstitutiv und weisen eine unterschiedliche Stärke auf (KALLNIK et al., 2010).

Um die Expression membranständiger Dehydrogensen während des Fermentationsprozesses zu verfolgen, eignet sich die Fusion mit dem FbFP evoglowPp1, das unabhängig von der verfügbaren Sauerstoffmenge fluoresziert.

\subsubsection{Die Expression von FbFP in G. oxydans unter der Kontrolle der drei verschiedenen Promotoren}

Die Konstruktion der Plasmide pBBR1p264-egPp1, pBBR1p384-egPp1 und pBBR1p452-egPp1 verlief erfolgreich. Dieser Arbeit wurden Plasmide mit den entsprechende Promotorregionen zur Verfügung gestellt, die auf dem broad-host-range cloning vector pBBR1MCS (KOVACH et al., 1994) basieren (Tab. 2.2.). Wie es in Kap. 2.4 beschrieben ist, wurde zunächst das Gen evoglow-Ppl von dem Plasmid pGLOW-Pp1 amplifiziert (Abb. 3.4.1.), in die Plasmide pBBR1p264, -p384 und -p452 hinter die entsprechenden Promotorregionen kloniert (Abb. 3.4.2.) und problemlos via Elektroporation in G. oxydans eingebracht (Abb. 3.4.3.). Anschließend wurden der 3'-Bereich der Promotorregion und das evoglowPp1-Gen per Sequenzierung überprüft und Klone, die den Erwartungen entsprachen für die folgenden fluoreszenzmikroskopischen Untersuchungen herangezogen. Die entsprechenden Sequenzen sind dem Anhang (Kap. 7.4) dieser Arbeit zu entnehmen.

Das Wachstum der Stämme scheint durch die Expression des Fluorophors im Vergleich zum Wildtyp beeinträchtigt zu werden. In der Reihenfolge der benutzten Promotoren p264, p384 und p452 sinkt die max. Wachstumsrate der Stämme unter Standardbedingungen von $0,45 / \mathrm{h}$ auf $0,39 / \mathrm{h}$, die nach $48 \mathrm{~h}$ erreichte OD $_{600}$ von 2,27 auf 2,08 (Tab. 3.4.1.). Der Wildtyp erreicht unter den gleichen Bedingungen eine Wachstumsrate von $0,46 / \mathrm{h}$ und eine $\mathrm{OD}_{600}$ nach $48 \mathrm{~h}$ von 2,70 . Bei der Betrachtung der Fluoreszenz der Stämme in Abb. 3.4.5. fällt auf, dass deren Intensität in der gleichen 
Reihenfolge schwächer wird, in der auch die max. Wachstumsrate abnimmt. Eine weitere wichtige Erkenntnis ist, dass die Fluoreszenz im Verlauf der exp. Wachstumsphase nicht schwächer wird. Im Falle des Stammes G. oxydans pBBR1p264-egPp1 scheint sie sogar noch zuzunehmen (Abb. 3.4.5.a und b). Einschlusskörper sind nicht zu erkennen.

Die Promotorstärken von p264 und p452 wurden in der Arbeit von KALLNIK et al. (2010) untersucht. Mittels des Reporter-Gens $\beta$-D-Glucuronidase konnte eine dreifach höhere Aktivität von p264 gegenüber p452 festgestellt werden. Die Expression des Arabitol-Dehydrogenase-Gens aus G. oxydans (GOX2181) unter der Kontrolle von p264 zeigte in einer Western Blot-Analyse eine zehnfach höhere Menge an exprimiertem Protein als unter der Kontrolle von p452. Demnach ist p264 ein stärkerer Promotor als p452. Die hier vorgestellten fluoreszenzmikroskopischen Aufnahmen bestätigen diese Ergebnisse. Ferner kann die Stärke des Promotors für das ribosomale Protein S12, p384 knapp hinter p264 aber deutlich vor p452 eingeordnet werden. Bemerkenswert ist, dass die mutmaßlich stärkere Expression, die zu einer stärkeren Fluoreszenz führt, das Wachstum der Stämme nicht in verstärktem Maße negativ beeinflusst. Lediglich eine kurze lag-Phase ist in den Stämmen G. oxydans pBBR1p264-egPp1 und -p384-egPp1 zu erkennen (Abb. 3.4.4.). Im Falle des Stammes G. oxydans pBBR1p452-egPp1 ist die lag-Phase kaum ausgeprägt, ähnlich wie beim Wildtyp unter Standardbedingungen (Abb. 3.3.1). Somit scheint evoglowPp1 für G. oxydans keine große Belastung darzustellen und sollte sich gut für das angestrebte Ziel einer Fusion mit einer membranständigen Dehydrogenase eignen.

Die Tatsache, dass die Expression inmitten der exp. Wachstumsphase nicht nachlässt, obwohl der Sauerstoffverbrauch der Zellen zu diesem Zeitpunkt stark ansteigt (SILBERBACH et al., 2003; HANKE et al., 2012), demonstriert neben der geringen Größe und der Herkunft aus einem Proteobakterium einen weiteren Vorteil des benutzten FbFP gegenüber z. B. GFP (MUKHERJEE et al., 2013).

Die Konstruktion der Plasmide, welche die Expression von evoglowPp1 unter der Kontrolle von drei konstitutiven Promotoren in G. oxydans ermöglichen sollten, verlief erfolgreich. Die Fluoreszenz der Stämme ist während der exponentiellen Wachstumsphase stabil und entspricht der erwarteten Promotorstärke. Dabei führt eine mutmaßlich stärkere Expression zu einer stärkeren Fluoreszenz, ohne das Wachstum der Stämme in verstärktem Maße negativ zu beeinflussen. 


\subsubsection{Die Konstruktion des Fusionsproteins aus GOX 1441 und des FbFP evoglowPp1 und die Expression in G. oxydans}

Die Konstruktion der Plasmide verlief letztendlich erfolgreich. Wie aus der Abb. 3.4.6. hervorgeht, sind durch die benutzten Primer einige Amplifikate verschiedenster Größe entstanden, deren Fusion ebenfalls zu einer Mischung an Fragmenten unterschiedlicher Größe führte (Abb. 3.4.7.). Diese Fusion war im Verlauf der Konstruktion erst möglich, nachdem der komplementäre Bereich der zu fusionierenden Fragmente von insgesamt 33 Nukleotiden (WURCH et al., 1998) auf 60 Nukleotide ausgedehnt wurde. Die fusionierten Gene wurden in die drei Plasmide pBBR1p264, pBBR1p384 sowie pBBR1p452 kloniert und anschließend in E. coli transformiert. Daraufhin konnten mittels Colony-PCR Klone mit Inserts von gewünschter Größe ausgewählt werden (Abb. 3.4.8.). Das Einbringen der Plasmide in G. oxydans via Elektroporation verlief erneut problemlos (Abb. 3.4.9.). Die Sequenzen des 3‘-Bereichs der Promotorregion und des Fusionsgens gox1441-evoglowPpl wurden überprüft. Die Sequenzen der letztendlich auf Wachstum und Fluoreszenz untersuchten Stämme von G. oxydans sind im Anhang aufgeführt (Kap. 7.4).

Die Fluoreszenz ist in allen untersuchten Stämmen sehr schwach (Abb. 3.4.11.). Die subjektive Wahrnehmung, dass die Fluoreszenz in Proben bei einer OD $_{600}$ von 0,5 etwas stärker war als bei einer OD von 0,2, geht aus der Abbildung nicht hervor. Es ist zumindest eine schwache Fluoreszenz zu erkennen, weshalb auch eine schwache Expression des Fusionsproteins zu vermuten ist. Der Wildtyp zeigt in dieser Phase des Wachstums i. d. R. keine Fluoreszenz, lediglich alte Kulturen weisen eine schwache Autofluoreszenz auf (keine Daten gezeigt). Ein Einbau des Fusionsproteins in die Cytoplasmamembran findet offensichtlich nicht statt, Einschlusskörper sind nicht zu erkennen (Abb. 3.4.11.).

Auch die im Vergleich zum Wildtyp schwächeren Wachstumsparameter der Stämme deuten darauf hin, dass eine Expression des Fusionsproteins durch G. oxydans zumindest initiiert wird. Zunächst fällt beim Betrachten der Wachstumskurven im Falle der stärkeren Promotoren p264 und p384 eine deutlich abgrenzbare lag-Phase auf, in der die $\mathrm{OD}_{600}$ sogar zurückgeht (Abb. 3.4.10.). Die erwiesene Expression von evoglowPp1 (Kap. 4.6.1) mit diesen beiden stärkeren Promotoren führte ebenfalls zu einer wenngleich schwächer ausgeprägten lag-Phase (Abb. 3.4.4.). Das Wachstum während der Expression von egPp1 und des Fusionsproteins unter der Kontrolle des 
p452-Promotors verläuft anfangs ähnlich. In beiden Fällen gibt es so gut wie keine lagPhase, die max. Wachstumsrate ist während der Expression des Fusionsproteins um ca. $5 \%$ geringer als während der Expression von egPp1 und führt zu einem um $2 \mathrm{~h}$ verzögerten Eintritt in die stat. Wachstumsphase. Zwar ist die nach $48 \mathrm{~h}$ erreichte $\mathrm{OD}_{600}$ bei der Expression von egPp1 mit 2,08 deutlich niedriger als bei der Expression des Fusionsproteins mit 2,72, dennoch ist zu vermuten, dass die Anwesenheit von egPp1 die Zelle weniger beeinträchtigt als das Fusionsprotein. Der Grund dafür könnte ein nach der Synthese falsch gefaltetes Fusionsprotein sein, was meist dazu führt, dass hydrophobe Bereiche des Proteins exponiert vorliegen und dies entweder deren Neufaltung oder deren Abbau einleitet (DOUGAN et al., 2002). Sollte dies der Fall sein, dann könnte der Abbau des Fusionsproteins im Falle des schwächeren Promotors p452 synchron zur Synthese verlaufen. Im Falle der stärkeren Promotoren p264 und p384 könnte eine höhere Menge an Fusionsprotein die deutlichen lag-Phasen erklären. Die Synthese verläuft zunächst schneller als der Abbau, die Entwicklung der einzelnen Zellen und deren Teilung verzögert sich. Der Vergleich der Stämme, in denen die Expression von egPp1 sowie dem Fusionsprotein unter der Kontrolle der beiden stärkeren Promotoren steht zeigt, dass ebenfalls eine höhere $\mathrm{OD}_{600}$ bei der Expression des Fusionsproteins als bei der Expression von egPp1 erreicht wird. Es wäre denkbar, dass das Fusionsprotein aufgrund einer falschen Faltung möglichst schnell der intrazellulären Proteolyse zugeführt wird. Es kann somit im weiteren Verlauf keinen mit dem egPp1 vergleichbaren Effekt auf das Wachstum ausüben, welches nicht abgebaut wird und zu einer relativ geringen $\mathrm{OD}_{600}$ führt.

Das Ergebnis dieser Fusion ist nicht zufriedenstellend. Die Fluoreszenz ist sehr schwach und eine Differenzierung der Promotorstärken ist damit nicht möglich. Eine Unterscheidung der Expressionsstärke ist aber entscheidend, wenn mit fluoreszierenden Fusionsproteinen die optimalen Bedingungen zu deren Expression untersucht werden sollen. Ein möglicher Ansatz zur Lösung dieses Problems könnte das Einfügen eines Linkers zwischen der Dehydrogenase GOX1441 und evoglowPp1 sein. Die räumliche Trennung zweier Domänen eines Proteins kann für dessen korrekte Faltung wichtig sein (GEORGE und HERINGA, 2003). Der Bereich zwischen den beiden Proteinen hat mit der Aminosäuren-Abfolge GOX1441 - F A L P K - M I N A K - egPp1 kein typisches Muster für helikale oder nicht-helikale Linker (GEORGE und HERINGA, 2003). Die Länge und deren Zusammensetzung können aber großen Einfluss auf die Stabilität von 
Proteinen besitzen (ROBINSON und SAUER, 1998) und somit für deren stabile Expression von entscheidender Bedeutung sein.

Die Expression des Fusionsproteins aus GOX1441 und evoglowPp1 führte nicht zu den erwünschten Ergebnissen. Die Sequenzen der Promotorregion und des Fusionsproteins entsprechen den Erwartungen, dennoch ist die Fluoreszenz aller Stämme zu schwach, um zwischen verschiedenen Promotorstärken und Fermentationsbedingungen unterscheiden zu können. Es ist zu vermuten, dass das Wachstum von G. oxydans durch das Fusionsprotein gestört wird. Ein Ansatz zur Lösung dieses Problems könnte das Einfügen eines Linkers zwischen der Dehydrogenase und dem Fluorophor sein. 


\section{Zusammenfassung}

Als intracytoplasmatische Membranen (ICM) in Gluconobacter oxydans durch CLAUS et al. (1975) zum ersten Mal beschrieben wurden, ist ihr Auftreten in der stationären Wachstumsphase für die zeitgleich gesteigerte Respirationsrate und Produktbildung verantwortlich gemacht worden. Dies wurde durch die erweiterte Membranoberfläche als Folge der ICM-Bildung begründet, welche den Einbau einer erhöhten Anzahl an membranständigen Dehydrogenasen ermöglicht. Das aktive Zentrum dieser Enzyme ist zum Periplasma gerichtet und ermöglicht somit die regiound stereoselektive Oxidation von Substraten, die hierfür nicht in das Cytosol aufgenommen werden müssen. Viele Produkte dieser unvollständigen Oxidationen sind wirtschaftlich interessant, $G$. oxydans hat sich mittlerweile als biotechnologisch relevantes Bakterium etabliert. Die vorliegende Arbeit beschäftigt sich mit den von CLAUS et al. (1975) gemachten Beobachtungen und legt Grundlagen für die mögliche Anwendung dieses Effekts in der Biotechnologie.

Mittels elektronenmikroskopischer und biochemischer Methoden ist es gelungen, die gemachten Beobachtungen $\mathrm{zu}$ bestätigen und zu erklären. Die Steigerung von Respiration und Produktbildung ist auf eine generelle Erhöhung der Anzahl an membranständigen Dehydrogenasen zurückzuführen. Unabhängig von der ICMBildung scheint der Substratumsatz zum Zeitpunkt des Übergangs von exponentieller zu stationärer Wachstumsphase seinen Höhepunkt zu haben. Die durch CLAUS et al. (1975) gemachten Beobachtungen sind auf ein verzögertes Wachstum zurückzuführen, welches durch das eingesetzte Substrat Glycerol hervorgerufen wurde. Dennoch ist ein Nutzen der ICM für die biotechnologische Anwendung nicht auszuschließen. Die Synchronisation der Zeitpunkte von ICM-Bildung und dem Höhepunkt der Expression von membranständigen Dehydrogenasen könnte die Produktbildung durch G. oxydans steigern. Darüber hinaus sind im Verlauf dieser Arbeit weitere Möglichkeiten zur Steigerung der Produktbildung durch G. oxydans entwickelt worden, die unter anderem mittels Fusionsproteinen aus membranständigen Dehydrogenasen und einem fluoreszierenden Protein untersucht werden könnten. Es ist gelungen, ein fluoreszierendes Protein, das auch unter starken Sauerstoffverbrauch uneingeschränkt fluoresziert, erfolgreich in G. oxydans zu exprimieren, während die Expression eines Fusionsproteins noch optimiert werden muss. 


\section{Literaturverzeichnis}

Agarwala, R., Ortlebb, S., Jayashree, K. S., Melzer, M. (2009). Immunoelectron Microscopy for Locating Calvin Cycle Enzymes in the Thylakoids of Synechocystis 6803. Mol. Plant, 2(1): 32-42.

Alauzet, C., Teyssier, C., Jumas-Bilak, E., Gouby, A., Chiron, R., Rabaud, C., Counil, F., Lozniewski, A., Marchandin, H. (2010). Gluconobacter as Well as Asaia Species, Newly Emerging Opportunistic Human Pathogens among Acetic Acid Bacteria. J. Clin. Microbiol., 48(11): 3935-3942.

Asai, T., (1935). Taxonomic studies on acetic acid bacteria and allied oxidative bacteria isolated from fruits. A new classification of the oxidative bacteria. J. Agric. Chem. Soc. Japan, 11: 674-708.

Batzing, B. L., Claus, G. W., (1973). Fine Structural Changes of Acetobacter suboxydans During Growth in a Defined Medium. J. Bacteriol., 113(3): 1455-1461.

Bauer, R., Katsikis, N., Varga, S., Hekmat, D. (2005). Study of the inhibitory effect of the product dihydroxyacetone on Gluconobacter oxydans in a semi-continuous twostage repeated-fed-batch process. Bioprocess Biosyst. Eng., 5: 37-43.

Berg, J. M., Tymoczko, J. L., Stryer L. (2003). Biochemie. 5. Auflage. Spektrum Akademischer Verlag GmbH, Heidelberg - Berlin.

Bradford, M. M. (1976). A rapid and sensitive method for the quantitation of microgram quantities of protein utilizing the principle of protein-dye binding. Anal. Biochem., 72: 248-254.

Claus, G. W., Batzing B. L., Baker, C. A., Goebel, E. M. (1975). Intracytoplasmic membrane formation and increased oxidation of glycerol during growth of Gluconobacter oxydans. J. Bacteriol., 123: 1169-1183. 
Cota-Robles, E. H. (1966). Internal Membranes in Cells of Escherichia Coli. J. Ultra. Mol. Struct. R., 16: 626-639.

Davies, S. L., Whittenburry, R. (1970) Fine Structure of Methane and Other Hydrocarbon-utilizing Bacteria. J. Gen. Microbiol., 61: 227-232.

Deppenmeier, U., Hoffmeister, M., Prust, C. (2002). Biochemistry and biotechnological applications of Gluconobacter strains. Appl. Microbiol. Biotechnol., 60: $233-242$.

Deppenmeier, U., Ehrenreich, A. (2009). Physiology of acetic acid bacteria in light of the genome sequence of Gluconobacter oxydans. J. Mol. Biotechnol., 16: 69-80.

De Muynck, C., Pereira C. S. S., Naessens, M., Parmentier, S., Soetaert, W., Vandamme, E. J. (2007). The Genus Gluconobacter Oxydans: Comprehensive Overview of Biochemistry and Biotechnological Applications. Cr. Rev. Biotechn., 27(3): $147-171$.

Dougan, D.A., Mogk, A., Bukau, B. (2002). Protein folding and degradation in bacteria: To degrade or not to degrade? That is the question. Cell. Mol. Life Sci., 59: 1607-1616.

Drepper, T., Huber, R., Heck, A., Circolone, F., Hillmer, A., Büchs, J., Jaeger, K. (2010). Flavin mononucleotide-based fluorescent reporter proteins outperform green fluorescent protein-like proteins as quantitative in vivo real-time reporters. Appl. Environ. Microbiol., 76(17): 5990-5994.

Du Toit, W. J., Pretorius, I.S. (2002). The occurence, control and esoteric effect of acetic acid bacteria in winemaking. Ann. Microbiol., 52: 155-179.

Dubochet, J., McDowall, A. W., Menge, B., Schmid, E. N., Lickfeld, K. G. (1983). Electron Microscopy of Frozen-Hydrated Bacteria. J. Bacteriol., 155(1): 381-390.

Egger, D., Bienz, K. (1994). Protein (western) blotting. Mol. Microbiol., 1(3): 289-305. 
George, R. A., Heringa, J. (2003). An analysis of protein domain linkers: their classification and role in protein folding. Protein Eng., 15(11): 871-879.

Greenberg, D. E., Porcella, S. F., Stock, F., Wong, A., Conville, P. S., Murray, P. R., Holland, S. M., Zelazny, A. M. (2006). Granulibacter bethesdensis gen. nov., sp. nov., a distinctive pathogenic acetic acid bacterium in the family Acetobacteraceae. Int. J. Syst. Evol. Microbiol., 56: 2609-2616.

Greenfield, S., Claus, G. W. (1972). Nonfunctional tricarboxylic acid cycle and the mechanism of glutamate biosynthesis in Acetobacter suboxydans. J. Bacteriol., 112: $1295-1301$.

Hanahan, D. (1983). Studies on transformation of Escherichia coli with plasmids. $J$. Mol. Biol., 166(4): 557-580.

Hanke, T., Richhardt, J., Polen, T., Sahm, H., Bringer, S., Bott, M. (2012). Influence of oxygen limitation absence of the cytochrome bc1 complex and low ph on global gene expression in Gluconobacter oxydans $621 \mathrm{H}$ using DNA microarray technology. J. Biotechnol., 157(3): 359-372.

Heefner D. L., Claus, G. W. (1976). Change in quantity of lipids and cell size during intracytoplasmic membrane formation in Gluconobacter oxydans. J. Bacteriol., 125(3): 1163-1171.

Heefner D. L., Claus, G. W. (1978). Lipid and fatty acid composition of Gluconobacter oxydans before and after intracytoplasmic membrane Formation. $J$. Bacteriol., 134: 38-47.

Hölscher T., Weinert-Sepalage D., Görisch H. (2007). Identification of membranebound quinoprotein inositol dehydrogenase in Gluconobacter oxydans ATCC $621 \mathrm{H}$. Microbiology, 153(2): 499-506. 
Hölscher T., Schleyer, U., Merfort, M., Bringer-Meyer, S., Görisch, H., Sahm, H. (2009). Glucose Oxidation and PWW-Dependent Dehydrogenases in Gluconobacter oxydans. J. Mol. Microbiol. Biotechnol., 16: 6-13.

Hoppert, M. (2003). Microscopic techniques in biotechnology. Weinheim, Germany: Wiley-VCH.

Kallnik, V., Meyer, M., Deppenmeyer, U., Schweiger, P. (2010). Construction of expression vectors for protein production in Gluconobacter oxydans. J. Biotechnol., 150: $460-465$.

Kersters, K., Lisdiyanti, P., Komagata, K., Swings, J. (2006). The Family Acetobacteraceae: The Genera Acetobacter, Acidomonas, Asaia, Gluconacetobacter, Gluconobacter, and Kozakia. Prokaryotes 5: 163-200. Springer, New York.

Kovach, M.E., Phillips, R.W., Elzer, P.H., Roop, R.M., Peterson, K.M. (1994). pBBR1MCS: a broad-host-range cloning vector. BioTechniques, 16: 801-802.

Lambert, B., Kersters, Gosselé, F., K. Swings, J., De Ley, J. (1980) Gluconobacter from Honey bees. A Van Leeuw. J. Microb., 47: 147-157.

Mascarenhas, J., Weber, M. H. W., Graumann, P. L. (2001). Specific polar localization of ribosomes in Bacillus subtilis depends on active transcription. EMBO reports, 2(8): 685-689.

Matsushita, K., Shinagawa, E., Adachi, O., Ameyama M. (1987). Purification and characterization of cytochrome o-type oxidase of Gluconobacter Suboxydans. Biochim. Biophys. Acta., 894(2): 304-312.

Matsushita K., Toyama H., Adachi O. (1994). Respiratory chains and bioenergetics of acetic acid bacteria. Adv. Microb. Physiol., 35: 247-301. 
Meyer, M., Schweiger, P., Deppenmeier, U. (2013). Effects of membrane-bound glucose dehydrogenase overproduction on the respiratory chain of Gluconobacter oxydans. Appl. Microbiol. Biotechnol., 97(8): 3457-3466.

Monod, J. (1949). The growth of bacterial cultures. Annu. Rev. Microbiol., 3: 371-394.

Mostafa, E., Heller, K. J., Arnold, A. (2002). Cloning of Escherichia coli lacZ and lacY Genes and Their Expression in Gluconobacter oxydans and Acetobacter liquefaciens. Appl. Environ. Microbiol., 68(5): 2619-2623.

Mukherjee, A., Walker, J., Weyant, K. B., Schroeder, C.M. (2013). Characterization of flavin-based proteins: An emerging class of fluorescent Reporters. PLoS One, 8(5): e64753.

Mullis, K. B., Faloona, F.A. (1987). Specific synthesis of DNA in vitro via a polymerase-catalyzed chain reaction. Methods. Enzymol., 155: 336.

Murray, R. G. E., Watson, S. W. (1965) Structure of Nitrosocystis oceanus and comparison Nitrosomonas and Nitrobacter. J. Bacteriol., 89(6): 1594-1609.

Oelze J. and Drews, G. (1971). Membranes of photosynthetic bacteria. Biochim Biophys. Acta., 203(2): 189-198.

Ohrem, H. L. and Merck, E. (1996). Inhibitory effects of glycerol on Gluconobacter oxydans. Biotechnol. Lett., 18: 245-250.

Ohrem, H. L. and Voss, H. (1996). Process model of the oxidation of glycerol with Gluconobacter oxydans. Process Biochem., 31: 295-301.

Olijve, W., and Kok, J. J., (1979). Analysis of Growth of Gluconobacter oxydans in Glucose Containing Media. Arch. Mikrobiol., 121: 283-290.

Oppenheim, J., Marcus, L. (1970). Correlation of Ultrastructure in Azotobacter vinelandii with Nitrogen Source for Growth. J. Bacteriol., 101(1): 286-291. 
Pate, J. L., Shah, V. K., Brill, W. J. (1973). Internal Membrane Control in Azotobacter vinelandii. J. Bacteriol., 114(3): 1364-1350.

Pestov, N. B., Rydström, J. (2007). Purification of recombinant membrane proteins tagged with calmodulin-binding domains by affinity chromatography on calmodulinagarose: example of nicotinamide nucleotide transhydrogenase. Nature Protocols, 2: 198-202.

Peters, B., Junker, A., Brauer, K., Mühlthaler, B., Kostner, D., Mientus, M., Liebl, W., Ehrenreich, A. (2012). Deletion of pyruvate decarboxylase by a new method for efficient markerless gene deletions in Gluconobacter oxydans. Appl. Microbiol. Biotechnol., 97(6): 2521-2530.

Peters B., Mientus, M., Kostner, D., Junker, A., Liebl, W., Ehrenreich, A. (2013) Characterization of membrane-bound dehydrogenases from Gluconobacter oxydans $621 \mathrm{H}$ via whole-cell activity assays using multideletion strains. Appl Microbiol Biotechnol, Epub ahead of print.

Piir, K., Paier, A., Liiv, A., Tenson, T., Maiväli, Ü. (2011). Ribosome degradation in growing bacteria. EMBO rep., 12(5): 458-462.

Pontefract, R. D., Bergeron, G., Thatcher, F. S. (1969). Mesosomes in Escherichia coli. J. Bacteriol., 97(1): 367-375.

Prust, C., Hoffmeister, M., Liesegang, H., Wiezer, A., Fricke, W.F., Ehrenreich, A., Gottschalk, G., Deppenmeier U. (2005) Complete genome sequence of the acetic acid bacterium Gluconobacter oxydans. Nat. Biotechnol., 23: 195-200.

Raspor, P., Goranovič, D. (2008). Biotechnological Applications of Acetic Acid Bacteria. Cr. Rev. Biotechn., 28: 101-124.

Reichstein, T., Grüssner, A. (1934). Eine ergiebige Synthese der 1-Ascorbinsäure (CVitamin). Helvetica Chimica Acta, 17: 311-315. 
Renart, J., Reiser, J., Stark, G. R. (1979). Transfer of proteins from gels to diazobenzyloxymethyl-paper and detection with antisera: A method for studying antibody specificity and antigen structure. Proc. Natl. Acad. Sci. U S A, 76: 3116-3120.

Reshetilov, A. N., Donova, M. V., Dovbnya, D. V., Il'yasov, P. V., Boronin, A. M., Leasers, T., and Green, R. (1998). Membrane-bound dehydrogenases of Gluconobacter oxydans: sensors for measuring sugars, alcohols, and polyoles. Bull. Exp. Biol. Med., 126: 702-704.

Robinow, C., Kellenberger, E. (1994). The Bacterial Nucleoid Revisited. Microbiol. Rev., 58(2): 211-232.

Robinson, C. R., Sauer, R. T. (1998). Optimizing the stability of single-chain proteins by linker length and composition mutagenisis. Proc. Natl. Acad. Sci. USA, 95: 59295934.

Saito, Y., Ishii, Y., Hayashi, H., Yoshikawa, K., Noguchi, Y., Yoshida, S., Soeda, S., Yoshida, M. (1998). Direct Fermentation of 2-Keto-L-Gulonic Acid in Recombinant Gluconobacter oxydans. Biotechnol. Bioeng., 58: 309-315.

Sambrook J., Fritsch E. F., Maniatis T. (1989). Molecular cloning: a laboratory manual. Cold Spring Habour Laboratory Press, Cold Spring Habour.

Sanger, F., Nicklen, S., Coulson, A. R. (1977). DNA sequencing with chainterminating inhibitors. Proc. Natl. Acad. Sci. U S A, 74: 5463-5467.

Sattler, K. (1965). Studien zur Intensivierung der Umwandlung von Glycerin in Dihydroxyaceton durch Acetobacter suboxydans. Zeitschr. Allg. Mikrobiol., 5(2): 136147.

Schiefelbein, S., Fröhlich, A., John, G. T., Beutler, F., Wittmann, C., Becker, J. (2013). Oxygen supply in disposable shake-flasks: prediction of oxygen transfer rate, oxygen saturation and maximum cell concentration during aerobic growth. Biotechnol. Lett., 35(8): 1223-1230. 
Scott, D., Brannan, J., Higgins, I. J. (1981). The Effect of Growth Conditions on Intracytoplasmic Membranes. J. Gen. Microbiol., 125: 63-72.

Segen, B. J., Gibson, K. D. (1971). Deficiencies of Chromatophore Proteins in Some Mutants of Rhodobacter spheroides with Altered Carotenoids. J. Bacteriol., 105(3): 701-709.

Sievers, M., Swings, J. (2005). The Proteobacteria, PartC $\alpha, \beta, \delta, \varepsilon-$ Proteobacteria. In Bergey's Manual of Systematic Bacteriology. New York: Springer Science.

Silberbach, M., Maier, B., Zimmermann, M., Büchs J. (2003). Glucose oxidation by Gluconobacter oxydans: characterization in shaking-flasks, scale-up and optimization of the pH profile. Appl. Microbiol. Biotechnol., 62(1): 92-98.

Silva, M. T., Sousa, J. C. F., Polónia J. J., Macedo, M. A. E., Parente, A. M. (1976). Bacterial Mesosomes. Real Structures or Artifacts? Biochim. Biophys. Acta, 443(1): 92105.

Singh, O. V., Kumar, R. (2007). Biotechnological production of gluconic acid: future implications. Appl. Microbiol. Biotechnol., 75: 713-722.

Snyder, R. W., Ruhe, J., Kobrin, S., Wasserstein, A., Doline, C., Nachamkin, I., Lipschutz. J. H. (2004). Asaia bogorensis peritonitis identified by 16S ribosomal RNA sequence analysis in a patient receiving peritoneal dialysis. Am. J. Kidney Dis., 44: $15-17$.

Strickland, J. E., Miller, O. N. (1968). Inhibition of Glycerol Dehydrogenase from Aerobacter aerogenes by Dihydroxyaceton, high ionoic strength and monovalent cations. Biochim. Biophys. Acta Enzymology, 159(2): 221-226.

Van Roessel, P., Brand, A. H. (2002). Imaging into the future: visualizing gene expression and protein interactions with fluorescent proteins. Nature Cell Biol. 4: E15 E20. 
Vatter, A. E., Wolfe, R. S. (1958). The structure of Photosynthetic Bacteria. J. Bacteriol., 75(4): 480-488.

Voss, J., Ehrenreich, A., Liebl, W. (2010). Characterization and inactivation of the membranebound polyol dehydrogenase in Gluconobacter oxydans DSM 7145 reveals a role in mesoerythritol oxidation. Microbiology, 156: 1890-1899.

Weenk, G., Olijve, W., Harder, W. (1984). Ketogluconate formation by Gluconobacter species. Appl. Microbiol. Biotechnol., 20: 400-405.

Werner T.C., Bunting, J. R., CATHOU, R. E. (1972). The Shape of Immunoglobulin G Molecules in Solution, Proc. Nat. Acad. Sci. USA, 69(4): 795-799.

White, S. A., Claus, G. W. (1982). Effect of Intracytoplasmic Membrane Development on Oxidation of Sorbitol and Other Polyols by Gluconobacter oxydans. J. Bacteriol 150(2): 934-943.

Wrede, C., Walbaum, U., Ducki, A., Heieren, I., Hoppert, M. (2013). Localization of Methyl-Coenzyme M Reductase as Metabolic Marker for Diverse Methanogenic Archaea. Archaea, Volume 2013 (2013), Article ID 920241.

Wurch, T., Lestienne F., Petrus J. P. (1998). A modified overlap extension PCR method to create chimeric genes in the absence of restriction enzymes. Biotechnology Techniques, 12(9): 635-657.

Wyss, O., Neumann, M. G., Socolofsky, M. D. (1961). Development and Germination of the Azotobacter Cyst. J. Biochem. Biophys. Cytol., 10: 555-565.

Yannisch-Perron, C., Vieira, J., Messing,J. (1985). Improved M13 phage cloning vectors and host strains: nucleotide sequences of the M13mp18 and pUC19 vectors. Gene, 33: 103-119. 


\section{Anhang}

\subsection{Materialien}

\subsubsection{Chemikalien}

Für die Herstellung von Puffern und Nährmedien wurden Chemikalien des höchsten handelsüblichen Reinheitsgrades verwendet. Diese stammten, sofern nicht anders vermerkt, von den Firmen:

Fluka [Neu-Ulm, Deutschland],

Merck [Darmstadt, Deutschland],

Roth GmbH Co [Karlsruhe, Deutschland],

Sigma Aldrich Chemie GmbH [Steinheim, Deutschland].

Außerdem wurden Chemikalien und Biochemikalien folgender Firmen verwendet:

$\begin{array}{ll}\text { Acrylamid-Bisacrylamid } 30 \%(37,5: 1) & \text { Roth, Karlsruhe } \\ \text { Agar } & \text { Roth, Karlsruhe } \\ \text { Agarose } & \text { Gibco, Eggenstein } \\ \text { Ammoniumpersulfat } & \text { Serva, Heidelberg } \\ \text { ß-Mercaptoethanol } & \text { Merck, Darmstadt } \\ \text { Bromphenolblau } & \text { Serva, Heidelberg } \\ \text { HABA } & \text { Merk, Darmstadt } \\ \text { HEPES } & \text { Sigma Aldrich Chemie GmbH, Steinheim } \\ \text { Chloroform } & \text { Roth, Karlsruhe } \\ \text { Coomassie Brillant Blue, G250 } & \text { Serva, Heidelberg } \\ \text { dNTPs } & \text { MBI Fermentas, St. Leon-Rot } \\ \text { EDTA } & \text { Serva, Heidelberg } \\ \text { Essigsäure (100\%) } & \text { Roth, Karlsruhe } \\ \text { Ethanol } & \text { Roth, Karlsruhe } \\ \text { Ethidiumbromid } & \text { Merck, Darmstadt }\end{array}$


Formaldehyd (37\%)

Glycerin

Glycin

Harnstoff

$\mathrm{H}_{2} \mathrm{O}_{2}$

Luminol

IPG Puffer

Methanol

O ktanol

Para-Coumarinsäure

SDS-Pellets

TEMED

Tetramethylrhodamin

Trichloressigsäure

Tris Roth, Karlsruhe

Trypsin-Resuspendierungspuffer

Tween 20

Trypton Oxoid, Heidelberg

Xylencyanol

\subsubsection{Hilfsmittel}

$0.2 \mu \mathrm{m}$ Polycarbonat Filter

15 ml Hartplastikröhrchen

$50 \mathrm{ml}$ Hartplastikröhrchen

Einmalspritzen

Eppendorfgefäße

Gelantinekapseln

Glaspipetten

Glasstreifen

Gene Amp Reaction Tubes (PCR)

Parafilm
Merck, Darmstadt

Fluka, Neu-Ulm

Roth, Karlsruhe

AppliChem, Darmstadt

Merck, Darmstadt

Fluka, Neu-Ulm

Amersham Bioscience GmbH, Freiburg

Roth, Karlsruhe

Roth, Karlsruhe

Sigma Aldrich Chemie GmbH, Steinheim

Roth, Karlsruhe

Merck, Darmstadt

Sigma Aldrich Chemie GmbH, Steinheim

Roth, Karlsruhe

Roth, Karlsruhe

Promega, Madison, WI, USA

Sigma, München

Oxoid, Heidelberg

Merck, Darmstadt

Millipore, Schwalbach

Sarstedt, Nümbrecht

Sarstedt, Nümbrecht

CODAN Medical Aps, Rødby, Dänemark

Greiner, Nürtingen

Plano, Wetzlar

Brand, Wertheim

LKB, Bromma, Schweden

Perkin Elmer, Weiterstadt

Pechiney Plastic Packaging Company,

Chicago, USA 
Petrischalen

Pipettenspitzen

Plastiknäpfe

PVDF-Membran

Glaspipetten Brand, Wertheim

Grids

Halbmikroküvetten aus Kunststoff

Kunststoffpetrischalen

Mikroliterpipetten

\subsubsection{Geräte und Apparaturen}

Autoklav Zirbus

Autoklav Thermo

Biofuge

Biofuge fresco

Detektion der Chemolumineszenz

Eismaschine

Elektroblotting

Trans-Blot Electrophoretic Cell

Elektroporationsgerät GenePulser II

Feinwaage Sartorius

Filtersatz EGFP HC

Fräse TM 60

French pressure cell press

FlexCycler (Thermocycler)

Gelelektrophoreseapparatur (SDS-PAGE)

Gelelektrophoreseapparatur (2D-PAGE)

Protean ${ }^{\circledR}$ II xi Vertical Electrophoresis

Cells

Heizblock
Greiner, Nürtingen

Greiner, Nürtingen

Eppendorf, Hamburg

Sarstedt, Nümbrecht

Plano, Wetzlar

AppliChem, Darmstadt,

Brand, Wertheim

Plano, Wetzlar

Greiner, Nürtingen

Greiner, Nürtingen

VWR, Darmstadt

Zirbus, Osterode

Thermo Scientific, Waltham, MA, USA

Heraeus Christ, Osterode

Heraeus Christ, Osterode

PEQLAB, Erlangen

Ziegra, Isernhagen

Bio-Rad Industries GmbH, München

Bio-Rad GmbH, München

Sartorius, Göttingen

AHF Analysentechnik, Tübingen

Reichert-Jung, Heidelberg

SLM Aminco, Lorch

Analytik Jena, Jena

Biometra, Göttingen

Bio-Rad Industries GmbH, München

Techne, England 
Horizontalschüttler

Inkubationswasserbad 1083 GFL,

IPG-Drystrip

IPGphor-Apparatur

IPGphor Isoelectric Focusing System

Knife-maker II LKB 7800

Kühlzentrifuge RC5C Sorvall

\section{Instruments}

Lichtmikroskop Zeiss Axiophot

Lichtmikroskop Zeiss Axioscop 40 FL

fluorescence mit Digitalkamera

Magnet-Heizrührer Reo basic $\mathrm{C}$

pH 525 Digital pH-Meter

Phosphor-Imager Storm 860

Quantifizierung der Expressionen

Image Station 440CF

Quecksilberlampe HBO 50

Spannungsgerät

Speed-Vac „Savant SC110“

Univapo Concentrator Centifuge Univapo

$150 \mathrm{H}$

Spektralphotometer Ultraspec 3000

Thermocycler FlexCycler

Transmissionselektronenmikroskop

Zeiss EM 902

Transmissionselektronenmikroskop

Jeol JEM-1011

Ultramikrotom FC 4

Ultraschall Gerät UP200S

UV Transilluminator 2000

Vortex Genie 2

Wasservollentsalzungsanlage

Zentrifugalkonzentrations-Säulen

(MWCO $30 \mathrm{kDa}$ )
IKA, Staufen

GFL, Burgwedel

Amersham Bioscience GmbH, Freiburg

Pharmacia Biotech, Freiburg

LKB, Bromma, Schweden

Kendro, Hanau

Carl Zeiss AG, Oberkochen

Carl Zeiss AG, Oberkochen

$\mathrm{IKA}^{\circledR}$-Werke, Staufen

WTW-GmbH, Weilheim

Molekular Dynamics, Ca. USA

Eastman Kodak Company, Rochester, NY, USA

Carl Zeiss AG, Oberkochen

Biometra, Göttingen

Savant Instruments, Holbrook, NY, USA

Zirbus, Osterode

Amersham Pharmacia, England

Analytik Jena, Jena

Carl Zeiss AG, Oberkochen

JEOL GmbH, Eching

Reichert-Jung, Heidelberg

Dr. Hielscher GmbH, Teltow

Bio-Rad Laboratories, Ca. USA

Bender \& Hobeing AG Zürich, Schweiz

Millipore, Schwalbach

Sartorius, Göttingen 


\subsubsection{Kommerziell erhältliche Systeme}

$\mathrm{BCA}^{\mathrm{TM}}$ Protein Assay Kit

DNA-Leitermix 1kb DNA Ladder

peqGOLD Gel Extraction Kit

peqGOLD MicroSpin Cycle-Pure Kit

peqGOLD Plasmid Miniprep Kit I

Prestained Protein Molecular Weight

Marker

\subsubsection{Enzyme und Proteine}

Calf intestinal alkalische Phosphatase (CIAP)

Goat-anti-rabbit IgG-10 nm Gold

Konjugat

Goat-anti-rabbit IgG Alkalische

Phosphatase Konjugat

Kaninchen-anti-GOX0854-Strep-

Primärantikörper

Kaninchen-anti-GOX1912-

Primärantikörper

Lysozym aus Hühnereiweiß

(178000 U/mg)

Phusion ${ }^{\circledR}$ High-Fidelity DNA Polymerase

Proteinase $\mathrm{K}$

Restriktionsenzyme

T4 DNA Ligase

Taq-DNA-Polymerase

Trypsin $\left(5000 \mathrm{u} \mathrm{mg}^{-1}\right)$
Pierce, Rockford, IL, USA

NEB Biolabs, Frankfurt am Main

PEQLAB, Erlangen

PEQLAB, Erlangen

PEQLAB, Erlangen

MBI Fermentas, St. Leon-Rot

MBI Fermentas, St. Leon-Rot

British Biocell International, Cardiff, UK

Promega, Madison, USA

Eurogentec, Seraing, Belgien

Eurogentec, Seraing, Belgien

Merck, Darmstadt

NEB Biolabs, Frankfurt am Main

Boehringer Mannheim GmbH, Mannheim

MBI Fermentas, St. Leon-Rot

MBI Fermentas, St. Leon-Rot

NEB Biolabs, Frankfurt am Main

Promega, Madison, WI, USA 


\subsection{Verwendete Internetangebote und Computerprogramme}

Die im Rahmen dieser Arbeit verwendeten Internetangebote und Computerprogramme sind in der Tabelle 7.2.1 aufgeführt.

Tab. 7.2.1 Internetangebote und Computerprogramme

\begin{tabular}{|c|c|c|}
\hline URL/Software & Anbieter & Anwendung \\
\hline AxioVision & $\begin{array}{l}\text { Carl Zeiss AG, } \\
\text { Oberkochen }\end{array}$ & $\begin{array}{l}\text { Kamerasteuerung und } \\
\text { Bildbearbeitung }\end{array}$ \\
\hline DigitalMicrograph & Gatan, Inc. & $\begin{array}{l}\text { Kamerasteuerung Jeol } \\
\text { 1011, Bildbearbeitung }\end{array}$ \\
\hline http://www.ncbi.nlm.nih.gov/ & $\begin{array}{l}\text { National Institutes } \\
\text { of Health, Bethesda, } \\
\text { USA }\end{array}$ & Literaturrecherche \\
\hline http://tools.neb.com/NEBcutter2 & NEB Biolabs & $\begin{array}{l}\text { Analyse von } \\
\text { Restriktionsschnittstellen }\end{array}$ \\
\hline http://us.expasy.org/ & $\begin{array}{l}\text { Swiss Institute of } \\
\text { Bioinformatics }\end{array}$ & $\begin{array}{l}\text { Recherchen zur } \\
\text { Proteinstruktur }\end{array}$ \\
\hline iTEM & Olympus & $\begin{array}{l}\text { Kamerasteuerung EM 902, } \\
\text { Bildbearbeitung }\end{array}$ \\
\hline Kodak Molekular Imaging 4.05 & $\begin{array}{l}\text { Eastman Kodak } \\
\text { Company }\end{array}$ & $\begin{array}{l}\text { Quantifizierung der } \\
\text { Expression }\end{array}$ \\
\hline Microsoft Office XP & Microsoft Inc. & $\begin{array}{l}\text { Text- und } \\
\text { Datenverarbeitung }\end{array}$ \\
\hline Photoshop 8.0 & Adope Corp & Bildbearbeitung \\
\hline
\end{tabular}




\subsection{Oligonukleotide}

Die Oligonukleotide wurden von der Firma Eurofins MWG Operon, Ebersberg bezogen. Die für diese Arbeit relevanten Oligonukleotide sind in der Tabelle 7.3.1 aufgeführt.

Tab. 7.3.1. Oligonukleotide

\begin{tabular}{|c|c|c|c|}
\hline Name & Sequenz $\left(5^{\prime} \rightarrow 3^{\prime}\right)$ & Schnittstelle & Beschreibung \\
\hline \multirow[t]{3}{*}{ SK033fwd } & AAAGAATTCATGATCAAC & EcoRI & Positivkontrollen \\
\hline & GCAAAACTCCTGC & & FbFP, Vorwärts- \\
\hline & & & Primer \\
\hline \multirow[t]{3}{*}{ SK034rev } & TTTAAGCTTTCAGTGCTTG & HindIII & Positivkontrollen \\
\hline & GCCTGGC & & FbFP, Rückwärts- \\
\hline & & & Primer \\
\hline \multirow[t]{3}{*}{ SK041 fwd } & CACGAGTGGCATGCCCGG & & Sequenzierung von \\
\hline & & & pBBR1p264- \\
\hline & & & Derivaten \\
\hline \multirow[t]{5}{*}{ SK042fwd } & AGTGACCAGATGGCCGCC & & Sequenzierung von \\
\hline & AATG & & Plasmiden, die das \\
\hline & & & Fusionsprodukt \\
\hline & & & gox1441-egPp1 \\
\hline & & & enthalten \\
\hline \multirow[t]{2}{*}{ SK043fwd } & TGAGCCCTCCGGCGTCAT & & Siehe SK042fwd \\
\hline & $\mathrm{C}$ & & \\
\hline \multirow[t]{2}{*}{ SK044fwd } & TCGATCAGCTTGCCTGCC & & Siehe SK042fwd \\
\hline & GG & & \\
\hline \multirow[t]{2}{*}{ SK045fwd } & TTCAGAACCGAGCTTGAT & & Siehe SK042fwd \\
\hline & GCCGG & & \\
\hline \multirow[t]{3}{*}{ SK046rev } & ACGCCAAGCGCGCAATTA & & Sequenzierung von \\
\hline & $\mathrm{ACCC}$ & & pBBR1p264, - -p384 \\
\hline & & & und $-\mathrm{p} 452$ \\
\hline \multirow[t]{3}{*}{ SK047fwd } & GGCGGTCCTACCGCATGT & & Sequenzierung von \\
\hline & $\mathrm{C}$ & & pBBR1p384- \\
\hline & & & Derivaten \\
\hline
\end{tabular}




\begin{tabular}{|c|c|c|c|}
\hline Name & Sequenz $\left(5^{\prime} \rightarrow 3^{\prime}\right)$ & Schnittstelle & Beschreibung \\
\hline SK048fwd & $\begin{array}{l}\text { CCGCTTTGCCGGAGGAAA } \\
\text { GG }\end{array}$ & & $\begin{array}{l}\text { Sequenzierung von } \\
\text { pBBR1p452- } \\
\text { Derivaten }\end{array}$ \\
\hline SK049fwd & $\begin{array}{l}\text { AAAGAATTCATGGCGCCG } \\
\text { TCTTCCGCCCGGCCG }\end{array}$ & EcoRI & $\begin{array}{l}\text { Amplifikation von } \\
\text { gox1441 für die } \\
\text { OEPCR, Vorwärts- } \\
\text { Primer }\end{array}$ \\
\hline SK050rev & $\begin{array}{l}\text { CATCAGTTGCAGGAGTTT } \\
\text { TGCGTTGATCATTTTCGGC } \\
\text { AACGCGAACGCCACGACC } \\
\text { TCGTC }\end{array}$ & & $\begin{array}{l}\text { Amplifikation von } \\
\text { gox1441 für die } \\
\text { OEPCR, Rückwärts- } \\
\text { Primer }\end{array}$ \\
\hline SK051fwd & $\begin{array}{l}\text { GACGAGGTCGTGGCGTTC } \\
\text { GCGTTGCCGAAAATGATC } \\
\text { AACGCAAAACTCCTGCAA } \\
\text { CTGATG }\end{array}$ & & $\begin{array}{l}\text { Amplifikation von } \\
\text { evoglowPpl für die } \\
\text { OEPCR, Vorwärts- } \\
\text { Primer }\end{array}$ \\
\hline SK052rev & $\begin{array}{l}\text { AAAAAGCTTTCAGTGCTT } \\
\text { GGCCTGGCCCTGCTGCC }\end{array}$ & HindIII & $\begin{array}{l}\text { Amplifikation von } \\
\text { evoglowPpl für die } \\
\text { OEPCR, Rückwärts- } \\
\text { Primer }\end{array}$ \\
\hline
\end{tabular}




\title{
7.4 Sequenzen
}

Die hier aufgeführten Sequenzen sind im Rahmen der Überprüfung von G. oxydansKlonen erhalten worden, die das Protein evoglowPp1 oder das Fusionsprotein GOX1441-evoglowPp1 unter der Kontrolle der Promotoren p264, p384 oder p452 exprimieren.

\section{Farblegende}

Promotorregion

Violett

Multiple Cloning Site

Grau

EcoRI-Schnittstelle

Grün

HindIII-Schnittstelle

Rot

evoglowPp1

Blau

gox 1441

Schwarz

Unterstrichen

Entspricht den Primern für die Sequenzierung

Doppelt unterstrichen

Entspricht den Primern für die Fusion der Gene gox1441 und evoglowPpl

G. oxydans pBBR1p264-egPp1, $723 \mathrm{bp},\left(5^{\prime} \rightarrow 3^{\prime}\right)$

\begin{abstract}
cgggccacgagtggcatgcccggccgtgcagagtctctgcaggatgcaggaccaatcgtttacggcgagg gagaccgaatttgggctgcaggaattcatgatcaacgcaaactcctgcaactgatggtcgaacattcca acgatggcatcgttgtcgccgagcaggaaggcaatgagagcatccttatctacgtcaacccggccttcga gcgcctgaccggctactgcgccgacgatattctctatcaggacgcccgttttcttcagggcgaggatcac gaccagccgggcatcgcaattatccgcgaggcgatccgcgaaggccgcccetgctgccaggtgctgcgca actaccgcaaagacggcagcctgttctggaacgagttgtccatcacaccggtgcacaacgaggcggacca gctgacctactacatcggcatccagcgcgatgtcacagcgcaagtattcgccgaggaaagggttcgcgag ctggaggctgaagtggcggaactgcgccggcagcagggccaggccaagcactgaaagcttatcgataccg tcgacctcgagggggggcccggtacccagcttttgttccctttagtgagggttaattgcgcgcttggcgt aatcatggtcatagctgtttcctgtgtgaaattgttatccgctcacaattccacacaacatacgagccgg aagcataagtgtaaagcctggc
\end{abstract}

G. oxydans pBBR1p384-egPp1, $788 \mathrm{bp},\left(5^{\prime} \rightarrow 3^{\prime}\right)$ 
tccttatctacgtcaacccggccttcgagcgectgaccggctactgcgecgacgatattctctatcagga cgcccgttttcttcagggcgaggatcacgaccagccgggcatcgcaattatccgcgaggcgatccgcgaa ggccgcccetgctgccaggtgctgcgcaactaccgcaaagacggcagcctgttctggaacgagttgtcca tcacaccggtgcacaacgaggcggaccagctgacctactacatcggcatccagcgcgatgtcacagcgca agtattcgccgaggaaagggttcgcgagctggaggctgaagtggcggaactgcgccggcagcagggccag gccaagcactgaaagcttatcgataccgtcgacctcgagggggggcccggtacccagcttttgttccett tagtgagggttaattgcgcgcttggcgtaatcatggtcatagctgtttcctgtgtgaattgttatccgc tcacaattccacacaacatacgagccggaagcataaagtgtaaagcctggggtgcctaatgagtgagcta actcacattaattgcgttgcgctcactgccegctttccagtcgggaaacctgtcgtgccagctgcattaa tgaatcggccaacgcgcg

\section{G. oxydans pBBR1p452-egPp1, $939 \mathrm{bp},\left(5^{\prime} \rightarrow 3^{\prime}\right)$}

tgttgcggtaactggataccgcatggctgaaaacggcggaaaaccgctgcgaatcacataattcaatgtg tgaacggggcttgacgtgcgcgctggagacggcaataaggccccacctgatccgctttgccggaggaaag ggtgctttcgggcaccgttttcgctgcaagcgccatccacggtgcggcccetggecgtgccccaagctgg aatgtcactatttgggctgcaggaattcatgatcaacgcaaactcctgcaactgatggtcgaacattcc aacgatggcatcgttgtcgccgagcaggaaggcaatgagagcatccttatctacgtcaacccggccttcg agcgcctgaccggctactgcgccgacgatattctctatcaggacgcccgttttcttcagggcgaggatca cgaccagccgggcatcgcaattatccgcgaggcgatccgcgaaggccgcccetgctgccaggtgctgcgc aactaccgcaaagacggcagcctgttctggaacgagttgtccatcacaccggtgcacaacgaggcggacc agctgacctactacatcggcatccagcgcgatgtcacagcgcaagtattcgccgaggaaagggttcgcga gctggaggctgaagtggcggaactgcgccggcagcagggccaggccaagcactgaaagcttatcgatacc gtcgacctcgagggggggcccggtacccagcttttgttccetttagtgagggttaattgcgcgcttggcg taatcatggtcatagctgtttcctgtgtgaaattgttatccgctcacaattccacacaacatacgagccg gaagcataaagtgtaaagcctggggtgcctaatgagtgagctaactcacattaattgcgttgcgctcact gccegcttccagtcgggaaacctgtcgt

\section{G. oxydans pBBR1p264-GOX1441-egPp1, 3125 bp, $\left(5^{\prime} \rightarrow 3^{\prime}\right)$}

tcgtttacggcgagggagaccgaatttgggctgcaggaattcatggcgccgtcttccgcccggccgttat tgcagaccetgaccggtattggtctcgccatactgggactggcectcttcctgccggggctgcggctcat cgcactgggtggttcattctattatgccgtggccggtctgctcatgatcctgtccggtatcatgctgacc atggggcggcggtccggtctggcaatctatgccgccettctggcctataccetgatctgggcgctgtggc gtgtcgggcttgatggetggcggctcattccgcccettgccettcctgccggcatcggtctgtgggtttt cggtccctggatcggcgggcggatgatggacagccagagccatgtccggatcaacagcaccgtcctagga ggcatgggaggctgtctggcgctgttcgtcgtcatgtttgcctgtggctggtacatcacgggccagcgct accagcagttcaaccctttcccaggctcaacgggagcgagcctgtccggaagtgaccagatggccgccaa tgactggcagttccatggcggcacaccggccggagaccgttttgcagccccgacgcagatcaacgcacag 
aacgcccataacctgaaggtcgcctgggtctatcacagtggcgatcttccccgacceggcgagaactccc gcggccgcgagttcagtttcaaagccacccccatcaagatcggcaatcgtctgttcttctgcacgccgca ccgtgacgtcgtggcgctggatgccacgaccggcaaggaagtctggcactaccggcccggcggcgagttt ggcgcgaatatctatcaggcctgccgcggcgtttcctatgccgatattccgggagcaacggactgcaccc atcgcatcatttcaacggattccggctccccgccgacgcttttcgcgcttgatgccgagaccgggcagct ctgtcacagcttcgggcatgacgggaagatcgaccttcgcgacggcatgggcaccattccgccgggcttt catttcatcacctccccgcccatggtcctgcacaaccggatcgtcaccagcggctgggtctatgatgacc agtccgttgatgagccetccggcgtcatccgcgccttcgacgccacgaccgggcaactcgcctgggcgtg ggacatgggccgcgttccggccaacagcccgctcggccccaacgaaaccttcacgcgcggaacaccgaat ggctggggcgtctatacggctgatgccgggctgaacatggtctatgtgccgctcggcattgccacgccgg actattatggcgtcaagcggcgtccgtttgacgagaaatacgacacgtctctcgctgcgctggacctgac gaccggcgaggaacgctggcattttcaggccgtgcatcatgatctgtgggatttcgatcttcccgtcggc ccgtctctggtcgatctgccggatgccagcggcacgcttacgceggecetcgtccagaccacgaagcagg gcgaactctttgttctggatcggcggacggggcagccgttctatcgtgtgcaggaaaaaccgttccggg tggggacatcccaaacgaacgctattccccgacccagccctattcggtggacatgccgaacctgcgtcgc cccgatttgacagaagatgatctgtggggcgccacaccattcgatcagcttgcetgccggatcgcctttc attccatgcgcttcaagggcctctacacaccacccagcgaacagggcacgatcggcttccccgccttcga tggcgtggcggactggtatggcggaacgatcgatccgacgcatggcgtcatgtatatcaacacgacgttc atcccgttccttatgacgctcgtgccgcatgacagggccgtgcaggaaggcctgttcaaaccctggcatg gatggaatcagccctatccggagccggttttcaccaacaatccgcagcatggcetgccetatgccgccgt catcaagccetggctcggactgttcggcgctccgtgccttgcgccgccetggggcaagatgcaggcgatc gatcttgttcatcgccgggtcatctgggagcgcgcactcggcaccacgaagaatgtcgggccgacaaca tgctgcggatgcetgtcggccttcccaccagcatcttctccatgggcggcagcgtgacgacgcccaacgg cctcgttttcatgggggcgctggcggatcagagcttccatattctggacgggcatgacggacacaccetg ttcagaaccgagcttgatgccggcggcaatgccacacccatgacctatatgggagaggacggacggcagt atgtcgtgctggccgtgggcggacatggcggactgaaaacgcggaacagcgacgaggtcgtggcgttcgc gttgccgaaatgatcaacgcaaaactcctgcaactgatggtcgaacattccaacgatggcatcgttgtc gccgagcaggaaggcaatgagagcatccttatctacgtcaacccggccttcgagcgcctgaccggctact gcgccgacgatattctctatcaggacgcccgttttcttcagggcgaggatcacgaccagccgggcatcgc aattatccgcgaggcgatccgcgaaggccgcccetgctgccaggtgctgcgcaactaccgcaaagacggc agcctgttctggaacgagttgtccatcacaccggtgcacaacgaggcggaccagctgacctactacatcg gcatccagcgcgatgtcacagcgcaagtattcgccgaggaaagggttcgcgagctggaggctgaagtggc ggaactgcgccggcagcagggccaggccaagcactgaaagcttatcgataccgtcgacctcgaggggggg cccggtacccagcttttgttccctttagtgagggttaattgcgcgcttggcgtaatcatggtcatagctg tttcctgtgtgaaattgttatccgctcacaattccacacaacatacgagccggaagcataaagtgtaaag cctggggtgcctaatgagtgagctaactcacattaattgcgttgc

\section{G. oxydans pBBR1p384-GOX1441-egPp1, $3210 \mathrm{bp},\left(5^{\prime} \rightarrow 3^{\prime}\right)$}

atgttgctgtctgaaataggacaaggattgggaagggcgccccgggctgcaggaattcatggcgccgtct tccgcccggccgttattgcagaccctgaccggtattggtctcgccatactgggactggccetcttcctgc 
cggggctgcggctcatcgcactgggtggttcattctattatgccgtggccggtctgctcatgatcctgtc cggtatcatgctgaccatggggcggcggtccggtctggcaatctatgccgccettctggcctataccetg atctgggcgetgtggcgtgtcgggettgatggetggcggctcattccgccecttgccettcctgccggca tcggtctgtgggttttcggtccctggatcggcgggcggatgatggacagccagagccatgtccggatcaa cagcaccgtcctaggaggcatgggaggctgtctggcgctgttcgtcgtcatgtttgcctgtggctggtac atcacgggccagcgctaccagcagttcaaccctttcccaggctcaacgggagcgagcctgtccggaagtg accagatggccgccaatgactggcagttccatggcggcacaccggccggagaccgttttgcagccccgac gcagatcaacgcacagaacgcccataacctgaaggtcgcctgggtctatcacagtggcgatcttccccga cccggcgagaactcccgcggccgcgagttcagtttcaaagccacccccatcaagatcggcaatcgtctgt tcttctgcacgccgcaccgtgacgtcgtggcgctggatgccacgaccggcaaggaagtctggcactaccg gcccggcggcgagtttggcgcgaatatctatcaggcctgccgcggcgtttcctatgccgatattccggga gcaacggactgcacccatcgcatcatttcaacggattccggctccccgccgacgcttttcgcgcttgatg ccgagaccgggcagctctgtcacagcttcgggcatgacgggaagatcgaccttcgcgacggcatgggcac cattccgccgggctttcatttcatcacctccccgcccatggtcctgcacaaccggatcgtcaccagcggc tgggtctatgatgaccagtccgttgatgagccctccggcgtcatccgcgccttcgacgccacgaccgggc aactcgcctgggcgtgggacatgggccgcgttccggccaacagcccgctcggccccaacgaaaccttcac gcgcggaacaccgaatggctggggcgtctatacggctgatgccgggctgaacatggtctatgtgccgctc ggcattgccacgccggactattatggcgtcaagcggcgtccgtttgacgagaaatacgacacgtctctcg ctgcgctggacctgacgaccggcgaggaacgctggcattttcaggccgtgcatcatgatctgtgggattt cgatcttcccgtcggcccgtctctggtcgatctgccggatgccagcggcacgcttacgccggccctcgtc cagaccacgaagcagggcgaactctttgttctggatcggcggacggggcagccgttctatcgtgtgcagg aaaaacccgttccgggtggggacatcccaaacgaacgctattccccgacccagccctattcggtggacat gccgaacctgcgtcgccccgatttgacagaagatgatctgtggggcgccacaccattcgatcagcttgcc tgccggatcgcctttcattccatgcgcttcaagggcctctacacaccacccagcgaacagggcacgatcg gcttccccgccttcgatggcgtggcggactggtatggcggaacgatcgatccgacgcatggcgtcatgta tatcaacacgacgttcatcccgttccttatgacgctcgtgccgcatgacagggccgtgcaggaaggcctg ttcaaaccetggcatggatggaatcagccctatccggagccggttttcaccaacaatccgcagcatggcc tgccctatgccgccgtcatcaagccctggctcggactgttcggcgctccgtgccttgcgcegccetgggg caagatgcaggcgatcgatcttgttcatcgccgggtcatctgggagcgcgcactcggcaccacgaagaat gtcgggccgacaaacatgctgcggatgcctgtcggccttcccaccagcatcttctccatgggcggcagcg tgacgacgcccaacggcctcgttttcatgggggcgctggcggatcagagcttccatattctggacgggca tgacggacacaccctgttcagaaccgagcttgatgccggcggcaatgccacacccatgacctatatggga gaggacggacggcagtatgtcgtgctggccgtgggcggacatggcggactgaaaacgcggaacagcgaco aggtcgtggegttcgcgttgccgaaatgatcaacgcaaactcctgcaactgatggtcgaacattccaa cgatggcatcgttgtcgccgagcaggaaggcaatgagagcatccttatctacgtcaacccggccttcgag cgcctgaccggctactgcgccgacgatattctctatcaggacgccegttttcttcagggcgaggatcacg accagccgggcatcgcaattatccgcgaggcgatccgcgaaggccgcccctgctgccaggtgctgcgcaa ctaccgcaaagacggcagcctgttctggaacgagttgtccatcacaccggtgcacaacgaggcggaccag ctgacctactacatcggcatccagcgcgatgtcacagcgcaagtattcgccgaggaaagggttcgcgagc tggaggctgaagtggcggaactgcgccggcagcagggccaggccaagcactgaaagcttatcgataccgt cgacctcgagggggggcccggtacccagcttttgttccctttagtgagggttaattgcgcgcttggcgta atcatggtcatagctgtttcctgtgtgaaattgttatccgctcacaattccacacaacatacgagccgga 
agcataaagtgtaaagcctggggtgcctaatgagtgagctaactcacattaattgcgttgcgctcactgc ccgcttccagtcgggaaacctgtcgtgccagctgcattaatgaatcggccaacgcgcgg

\section{G. oxydans pBBR1p452-GOX1441-egPp1, 3158 bp, (5' $\left.\rightarrow 3^{\prime}\right)$}

cggtgcggcccetggcegtgccccaagctggaatgtcactatttgggctgcaggaattcatggcgccgtc ttccgcccggccgttattgcagaccctgaccggtattggtctcgccatactgggactggccctcttcctg ccggggctgcggctcatcgcactgggtggttcattctattatgccgtggccggtctgctcatgatcctgt ccggtatcatgctgaccatggggcggcggtccggtctggcaatctatgccgccettctggcctataccet gatctgggcgctgtggcgtgtcgggcttgatggctggcggctcattccgcecettgecettcctgccggc atcggtctgtgggttttcggtccctggatcggcgggcggatgatggacagccagagccatgtccggatca acagcaccgtcctaggaggcatgggaggctgtctggcgctgttcgtcgtcatgtttgcctgtggctggta catcacgggccagcgctaccagcagttcaaccctttcccaggctcaacgggagcgagcctgtccggaagt gaccagatggccgccaltgactggcagttccatggcggcacaccggccggagaccgttttgcagccccga cgcagatcaacgcacagaacgcccataacctgaaggtcgcctgggtctatcacagtggcgatcttccccg acccggcgagaactcccgcggccgcgagttcagtttcaaagccacccccatcaagatcggcaatcgtctg ttcttctgcacgccgcaccgtgacgtcgtggcgctggatgccacgaccggcaaggaagtctggcactacc ggcccggcggcgagtttggcgcgaatatctatcaggcctgccgcggcgtttcctatgccgatattccggg agcaacggactgcacccatcgcatcatttcaacggattccggctccccgccgacgctttcgcgcttgat gccgagaccgggcagctctgtcacagcttcgggcatgacgggaagatcgaccttcgcgacggcatgggca ccattccgccgggcttcattcatcacctccccgcccatggtcctgcacaaccggatcgtcaccagcgg ctgggtctatgatgaccagtccgttgatgagccctccggcgtcatccgcgccttcgacgccacgaccggg caactcgcctgggcgtgggacatgggccgcgttccggccaacagccegctcggecccaacgaaaccttca cgcgcggaacaccgaatggctggggcgtctatacggctgatgccgggctgaacatggtctatgtgccgct cggcattgccacgccggactattatggcgtcaagcggcgtccgtttgacgagaaatacgacacgtctctc gctgcgctggacctgacgaccggcgaggaacgctggcattttcaggccgtgcatcatgatctgtgggatt tcgatcttcccgtcggccegtctctggtcgatctgccggatgccagcggcacgcttacgceggcectcgt ccagaccacgaagcagggcgaactctttgttctggatcggcggacggggcagccgttctatcgtgtgcag gaaaacccgttccgggtggggacatcccaaacgaacgctattccccgacccagccctattcggtggaca tgccgaacctgcgtcgecccgatttgacagaagatgatctgtggggcgccacaccattcgatcagcttgc ctgccggatcgcetttcattccatgcgcttcaagggcctctacacaccacccagcgaacagggcacgatc ggcttccccgccttcgatggcgtggcggactggtatggcggaacgatcgatccgacgcatggcgtcatgt atatcaacacgacgttcatcccgttccttatgacgctcgtgccgcatgacagggccgtgcaggaaggcct gttcaaaccctggcatggatggaatcagccctatccggagccggttttcaccaacaatccgcagcatggc ctgccctatgccgccgtcatcaagccetggctcggactgttcggcgctccgtgccttgcgccgccetggg gcaagatgcaggcgatcgatcttgttcatcgccgggtcatctgggagcgcgcactcggcaccacgaagaa tgtcgggccgacaaacatgctgcggatgcctgtcggcettcccaccagcatcttctccatgggcggcagc gtgacgacgcccaacggcctcgttttcatgggggcgctggcggatcagagcttccatattctggacgggc atgacggacacaccctgttcagaaccgagcttgatgccggcggcaatgccacacccatgacctatatggg agaggacggacggcagtatgtcgtgctggccgtgggcggacatggcggactgaaaacgcggaacagcgac 
gaggtcgtggcgttcgegttgccgaaaatgatcaacgcaaaactcctgcaactgatggtcgaacattcca acgatggcatcgttgtcgccgagcaggaaggcaatgagagcatccttatctacgtcaacccggccttcga gcgcetgaccggctactgcgccgacgatattctctatcaggacgccegttttcttcagggcgaggatcac gaccagccgggcatcgcaattatccgcgaggcgatccgcgaaggccgcccetgctgccaggtgctgcgca actaccgcaaagacggcagcctgttctggaacgagttgtccatcacaccggtgcacaacgaggcggacca gctgacctactacatcggcatccagcgcgatgtcacagcgcaagtattcgccgaggaaagggttcgcgag ctggaggctgaagtggcggaactgcgccggcagcagggccaggccaagcactgaaagcttatcgataccg tcgacctcgagggggggcccggtacccagcttttgttccctttagtgagggttaattgcgcgcttggcgt aatcatggtcatagctgtttcctgtgtgaaattgttatccgctcacaattccacacaacatacgagccgg aagcataaagtgtaaagcctggggtgcctaatgagtgagctaactcacattaattgcgttgcgctcactg ccegctt 


\subsection{Lebenslauf}

\section{Persönliche Daten}

Name:

Sebastian Kokoschka

Anschrift:

Lange Geismarstraße 51

37073 Göttingen

Geburtsdatum und Geburtsort: $\quad$ 10. Oktober 1977 in Göttingen

Staatsangehörigkeit:

deutsch

Familienstand:

ledig

\section{Schulische Ausbildung}

1984 - 1988 Grundschule in Dramfeld, Landkreis Göttingen.

1988 - 1997 Georg-Christoph-Lichtenberg Gesamtschule in Göttingen-Geismar. Abschluss: Abitur (Note: 2,4).

\section{Zivildienst}

1997 - 1998 Zivildienst im Krankenhaus Neu-Bethlehem, Göttingen, auf der internistischen Station.

\section{Studium}

1999 - 2001 Medizinstudium an der Georg-August-Universität zu Göttingen.

$2001-2009$ Biologiestudium an der Georg-August-Universität zu Göttingen. Abschluss: Diplom-Biologe (Note: sehr gut).

2009 - 2013 Promotion an der Georg-August-Universität zu Göttingen.

\section{Beruflicher Werdegang}

Mai 2009 Studentische Hilfskraft in der Arbeitsgruppe von PD Dr. Hoppert im Institut für Mikrobiologie und Genetik der Georg-August-Universität zu Göttingen. Es wurde unterstützende Arbeit in der Forschung geleistet. 
April 2013 Studentische Hilfskraft in der Arbeitsgruppe von PD Dr. Hoppert im Institut für Mikrobiologie und Genetik der Georg-August-Universität zu Göttingen. Es wurde unterstützende Arbeit in der Ausbildung von Studenten geleistet.

\section{Besondere Kenntnisse}

\section{Sprachkenntnisse}

Englisch - gute Sprach- und sehr gute Lesekenntnisse.

\section{EDV}

Microsoft Office

Adobe Photoshop (Bildbearbeitung)

Chromas Lite/ BioEdit (Bearbeitung von Nukleinsäuresequenzen)

\section{Lehrtätigkeit}

2008 - 2009 Als studentische Hilfskraft war ich an der Ausbildung von Medizinstudenten im Fach Biochemie beteiligt.

\section{Führerschein}

Klasse 3

\section{Interessen}

In meiner Freizeit höre und mache ich Musik und lese viel. Ich bin gern in der Natur um zu wandern und zu angeln. 
